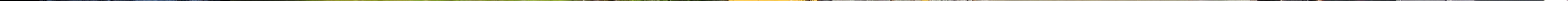




\title{
Alaska's Mineral Industry 2009
}

by

D.J. Szumigala, L.A. Harbo, and R.A. Hughes

\section{SPECIAL REPORT 64}

\author{
DEPARTMENT OF NATURAL RESOURCES \\ Division of Geological \& Geophysical Surveys
}

in cooperation with

\author{
DEPARTMENT OF COMMERCE, COMMUNITY \& ECONOMIC DEVELOPMENT \\ Division of Economic Development
}

Front wraparound cover photo: Mill, crusher, and processing plant at the Kensington Mine; Jualin Portal is nearby.

The crushed ore bin is at left and the freshwater tank is at right. Lions Head Mountain towers in the background.

Vertical photos, top to bottom:

- Gold in quartz-pyrite vein from the Kensington Mine.

- Conveyor belt transports ore to top of crushed ore bin at Kensington mill facilities.

- A Kensington Mine worker logs drill core at the Comet Beach core facility.

- Interior of the Kensington mill facility with the grinding units in the foreground.

- Tug and barge with a load of supplies and equipment heads to the Kensington Mine project.

- Mine worker is silhouetted in Comet Portal entrance.

All photos courtesy of Coeur Alaska Inc.

The QR (quick response) code in the bottom corner of the front cover is an encoded URL, scannable by mobile devices. This URL will take you to the web page for this report, http://www.dggs.alaska. 



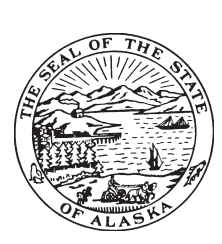

STATE OF ALASKA

Sean Parnell, Governor

DEPARTMENT OF COMMERCE, COMMUNITY \& ECONOMIC DEVELOPMENT

Susan K. Bell, Commissioner

DIVISION OF ECONOMIC DEVELOPMENT

Wanetta Ayers, Director

DEPARTMENT OF NATURAL RESOURCES

Tom Irwin, Commissioner

DIVISION OF GEOLOGICAL \& GEOPHYSICAL SURVEYS

Robert F. Swenson, State Geologist and Director

DGGS publications may be inspected at the following locations. Address mail orders to the Fairbanks office.

\author{
Alaska Division of Geological \\ \& Geophysical Surveys \\ ATTN: Geologic Communications \\ 3354 College Road \\ Fairbanks, Alaska 99709-3707 \\ Elmer E. Rasmuson Library \\ University of Alaska Fairbanks \\ Fairbanks, Alaska 99775-1005
}

\author{
University of Alaska Anchorage \\ Consortium Library \\ 3211 Providence Drive \\ Anchorage, Alaska 99508
}

ARLIS (Alaska Resource Library
$\quad$ and Information Service)
3211 Providence Drive
Anchorage, Alaska 99508

Alaska State Library

State Office Building, 8th Floor

333 Willoughby Avenue

Juneau, Alaska 99811-0571

This publication, released by the Division of Geological \& Geophysical Surveys (DGGS), was produced and printed in Fairbanks, Alaska, by UAF Printing Services, at a cost of $\$ 6.94$ per copy. Authority to print this and other publications comes from Alaska Statute 41.08.020, which charges DGGS "to determine the potential of Alaskan land for production of metals, minerals, fuels, and geothermal resources; the location and supplies of groundwater and construction materials; the potential geologic hazards to buildings, roads, bridges, and other installations and structures; and . . conduct such other surveys and investigations as will advance knowledge of the geology of Alaska." In addition, Alaska Statute 41.08.030 states, "The state geologist shall print and publish an annual report and such other special and topical reports and maps as may be desirable for the benefit of the state..." 



\section{EXECUTIVE SUMMARY}

Alaska's Mineral Industry 2009 is the 29th annual report produced by the Division of Geological \& Geophysical Surveys (DGGS, an agency of the Department of Natural Resources) and the Division of Economic Development (of the Department of Commerce, Community and Economic Development). This report and data supersede the summary report published earlier this year, DGGS Information Circular 60.

The total value of Alaska's mineral industry in 2009 dropped to $\$ 2.966$ billion, $\$ 204.2$ million and nearly 7 percent lower than 2008's value of $\$ 3.171$ billion. The decline in total value resulted from a decrease in spending on exploration and development. The total value is a combination of expenses and receipts, and although it is not a typical accounting tool, it is an effective way to track the annual strength of the mineral industry. The year 2009 was the 14th consecutive year that the total value of the Alaska mineral industry exceeded \$1 billion and the fourth consecutive year the total value exceeded $\$ 2$ billion.

Total employment by the Alaska minerals industry in 2009 was 3,280 full-time-equivalent jobs, a decrease of 112 jobs (3.5 percent) from the 2008 total of 3,392 full-time-equivalent jobs. The largest change in employment compared to 2008 was the drop in mineral development jobs from 516 to 371, a 28 percent decrease. The average monthly wage for mining in Alaska during 2009 was \$7,588.

The mineral industry paid a total of $\$ 67.94$ million in royalty and tax payments to the State of Alaska and Alaska municipalities in 2008. The total for 2009 payments was not available at press time. State mineral rents and royalties amounted to $\$ 6.4$ million; sales of rock, sand, and gravel amounted to $\$ 4.7$ million; and mining license taxes totaled $\$ 29.73$ million in 2009. Mining companies were the largest taxpayers in the City and Borough of Juneau and the Fairbanks North Star Borough. Red Dog Mine paid \$6.7 million to the Northwest Arctic Borough in 2009 as Payment in Lieu of Taxes (PILT). Mining companies contributed to the Denali Borough through PILT and severance tax payments. The Alaska Industrial Development \& Export Authority (AIDEA) was paid annual user fees of $\$ 15.9$ million by mining companies for use of the DeLong Mountain Regional Transportation System and the Skagway Ore Terminal.

Exploration expenditures were $\$ 180$ million, a 48 percent drop from the record $\$ 347.3$ million expended on exploration in 2008. Mineral exploration expenditures in Alaska account for approximately one-third of the United States total. At least 62 Alaskan projects spent more than $\$ 100,000$ each and 23 of those projects spent more than $\$ 1$ million each. These projects spanned Alaska. Copper-gold-molybdenum porphyry systems were the major exploration target in 2009, followed by intrusion-related gold deposits. Exploration was also conducted on various gold-quartz vein deposits; base-metal-rich, polymetallic massive-sulfide deposits; platinum-group-element-nickel-copper ultramafichosted deposits; and rare-earth-element, diamond, tin, coal, placer gold, and other deposit types. The Money Knob deposit near Livengood led the pack in new mineral discoveries and drilling footage total. Advanced exploration projects include the 35.3-million-ounce Donlin Creek intrusion-hosted gold project near Aniak, the Pebble copper-goldmolybdenum porphyry project in southwestern Alaska, and the Niblack polymetallic volcanogenic massive sulfide project in southeastern Alaska. The Pebble project, with estimated resources of 72 billion pounds of copper, 94 million ounces of gold, and 4.8 billion pounds of molybdenum, was the largest exploration project in 2009.

Development expenditures for 2009, reported for 27 projects, totaled $\$ 330.8$ million, down 16.5 percent from the $\$ 396.2$ million spent in 2008, but still the sixth year with development expenditures exceeding \$200 million. Tailings storage facilities were expanded at Red Dog Mine. All major underground development activities and surface facilities at Kensington except the tailings facility were completed in 2009. At Fort Knox Mine, construction of the heap leach facilities continued, studies were initiated regarding increasing the height of the tailings dam, and final reclamation of True North began. At Nixon Fork Mine, an evaluation plan began, and a new resource estimate is expected in fall 2010. At Greens Creek Mine, underground in-fill drilling and preliminary production expenditures were noted. Rock Creek Mine continued in care and maintenance status. PacRim Coal LP continued environmental, permitting, and engineering work on the Chuitna Coal project near Anchorage.

Mineral production volumes remain strong, and the value of mineral production was slightly higher in 2009 than in 2008. Production values for 2009 were $\$ 2,455.6$ million compared to $\$ 2,427.1$ million in 2008 , an increase of more than 1 percent. Production volumes of zinc, lead, silver, and placer gold increased; the production volume of lode gold declined slightly. The value of zinc, silver, and gold produced increased, whereas the value of lead produced declined 6 percent. Zinc accounted for 43.5 percent of the total production value, followed by gold at 30.9 percent. 
Red Dog Mine was the largest mineral producer in Alaska during 2009, with 53.3 percent of the production value. Other significant producers, in order of value of product, were Pogo Mine (15.4 percent), Greens Creek Mine (12.9 percent), and Fort Knox Mine (10.4 percent). International mineral exports from all companies were valued at $\$ 980$ million.

Zinc production from all Alaskan producers totaled 712,496 tons in 2009. Lead production was 167,204 tons. Gold production was 780,657 ounces, and silver production was estimated at 15.6 million ounces. Sand and gravel production was 7.1 million tons and rock production was 1.8 million tons; however, reporting shortages were noted in this sector. More than 1.86 million tons of coal was produced. Peat production was estimated to be 240,510 cubic yards; reporting deficits were also noted in this area.

Hard-rock (lode) gold production decreased approximately 3 percent in 2009, to 720,407 ounces from 743,993 ounces in 2008. Pogo Mine was the largest producer of gold in Alaska with 389,808 ounces produced. Placer production in Alaska increased in 2009 to 60,250 ounces, up more than 6 percent from 56,759 ounces in 2008. Approximately 234 placer gold operations reported production in Alaska in 2009 compared to 195 in 2008.

The Alaska Division of Geological \& Geophysical Surveys (DGGS) in early 2009 released airborne magnetic and electromagnetic geophysical maps for 442 square miles of the northern Chistochina mining district. During July 2009 , geologists from the Mineral Resources Section of DGGS conducted geologic mapping of about 113 square miles of the geophysical survey tract in the southern foothills of the Alaska Range, about 140 miles southeast of Fairbanks and 20 miles east of Paxson. DGGS also conducted geologic fieldwork along the proposed gas pipeline corridor and the Alaska Highway from Tetlin Junction to the Yukon Territory-Alaska border. Surficial and bedrock mapping were completed at a scale of $1: 63,360$.

The State of Alaska, through DGGS, funded and acquired airborne magnetic, electromagnetic, and radiometric geophysical data for approximately 650 square miles of mixed state- and Native-owned lands centered on Moran Creek and Moran Dome in the Tanana and Melozitna quadrangles. Survey data and maps for this area about 150 miles westnorthwest of Fairbanks and 25 miles west of the village of Tanana will be released in 2010.

The Alaska Railroad transported 2.31 million tons of rock, sand, and gravel and 1.56 million tons of coal during 2009. The transportation of mineral products (coal, sand, and gravel) generated $\$ 22.4$ million in revenue for the Alaska Railroad in 2009. 


\section{CONTENTS}

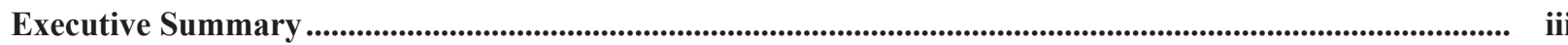

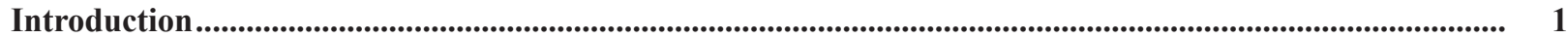

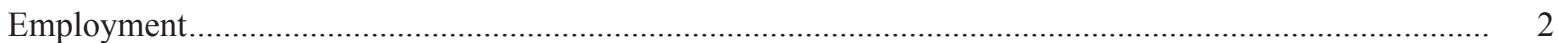

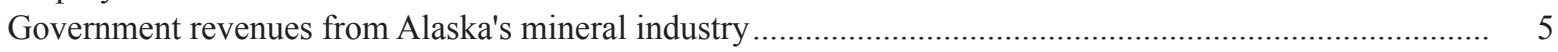

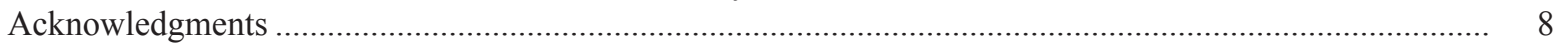

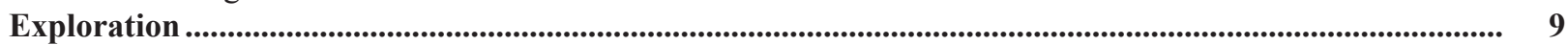

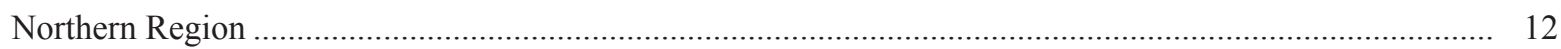

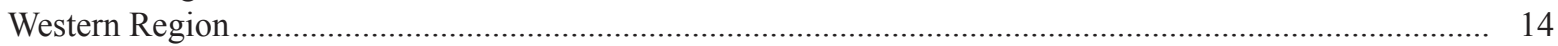

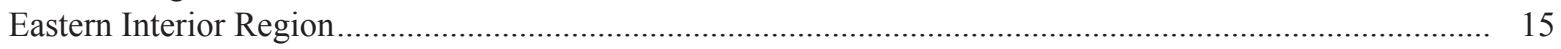

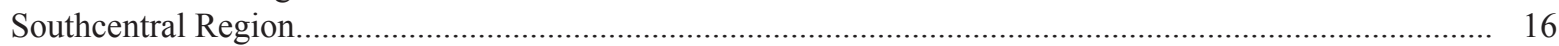

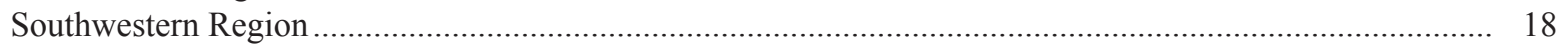

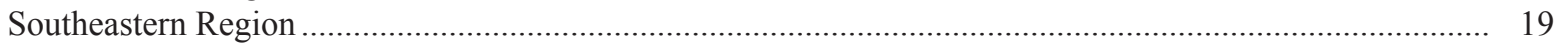

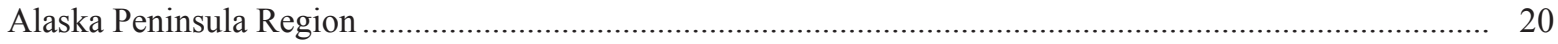

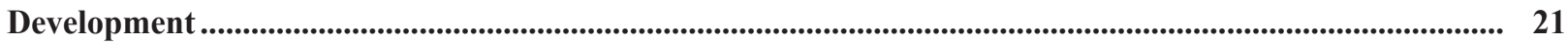

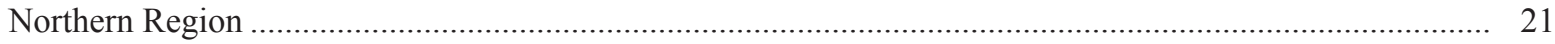

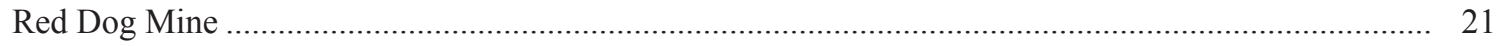

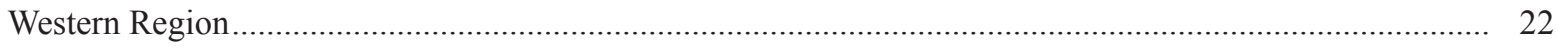

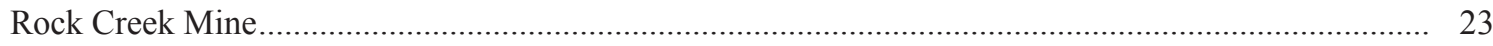

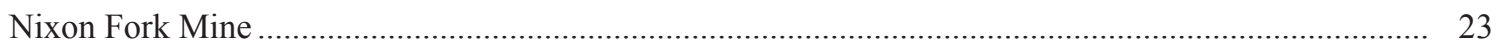

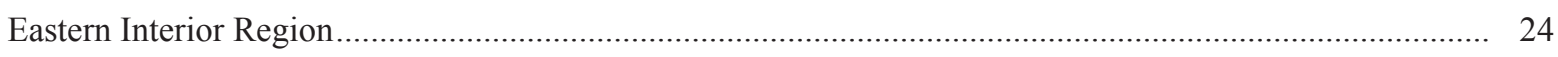

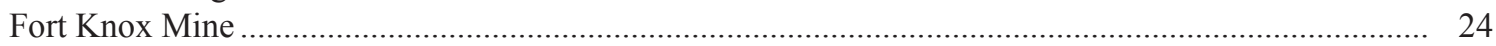

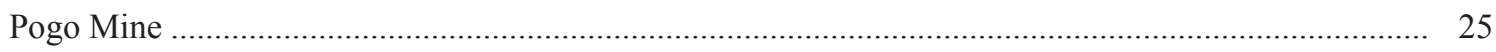

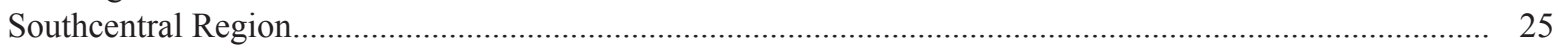

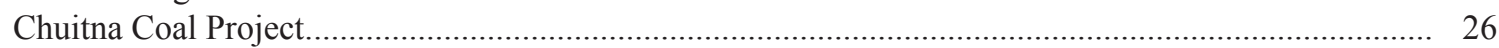

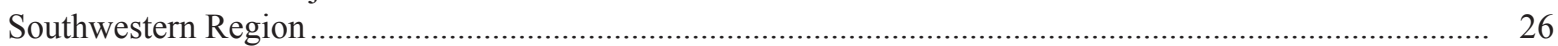

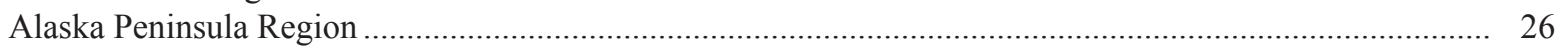

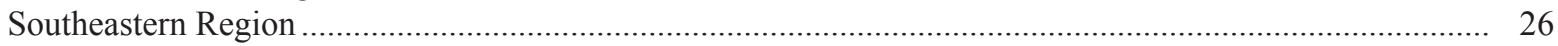

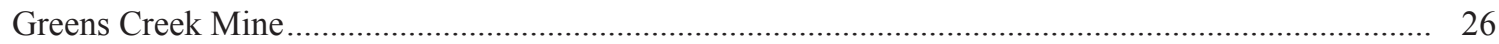

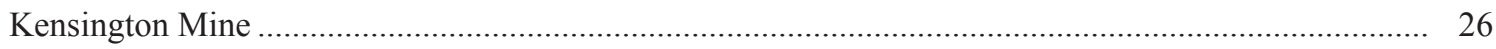

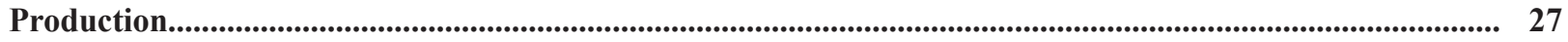

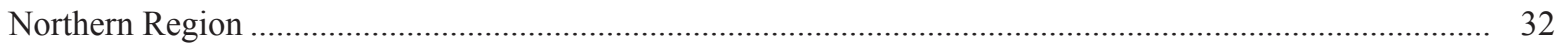

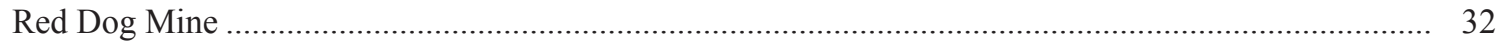

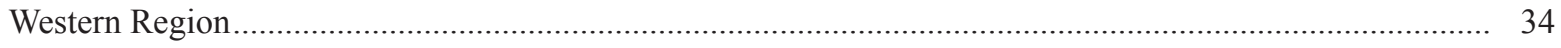

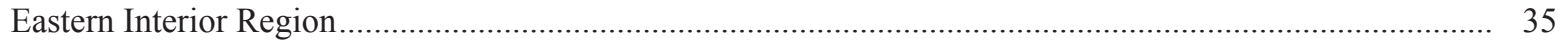

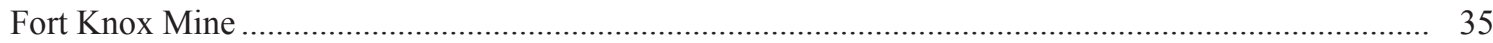

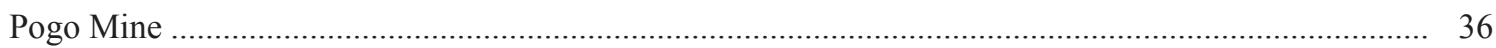

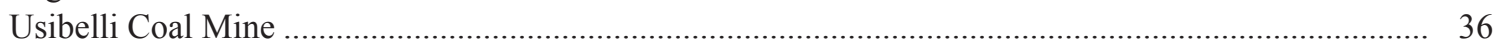

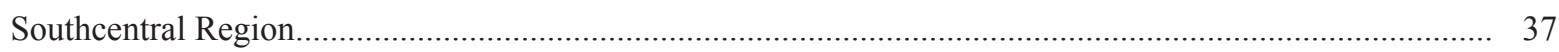

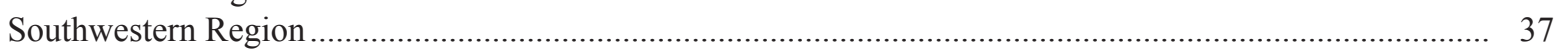

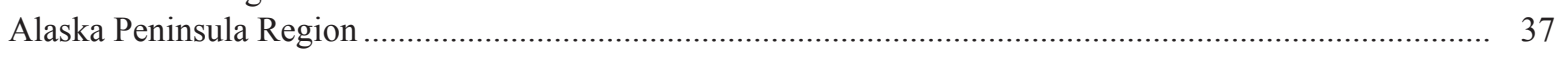

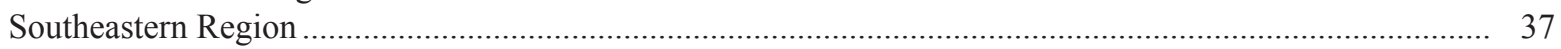

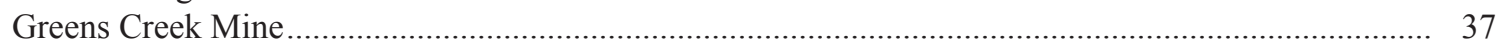

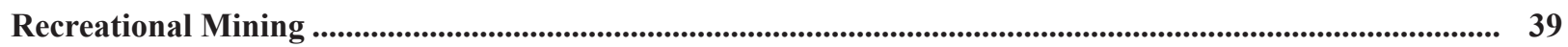

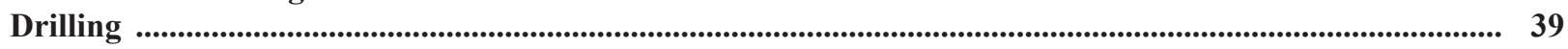

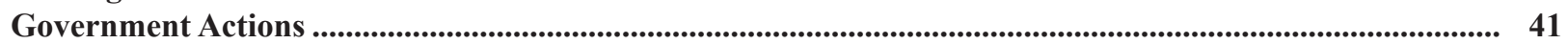

\section{Appendixes}

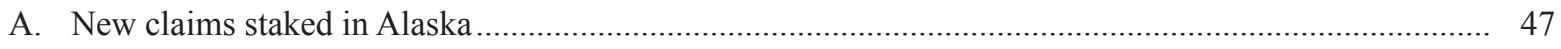

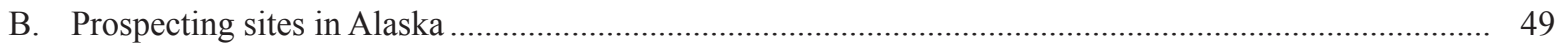

C. Selected significant mineral deposits and mineral districts in Alaska ................................................... 51 


\section{CONTENTS}

D. Companies and individuals reported to be producing metal in Alaska......

E. Websites for commercial recreational mining ventures and mining-related attractions in Alaska........... 67

F. State and federal agencies and private interest groups involved in mineral development activities........ 68

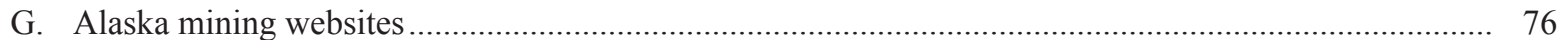

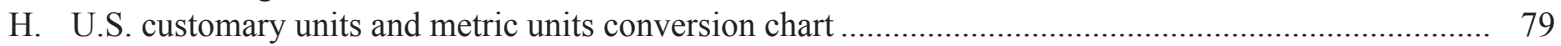

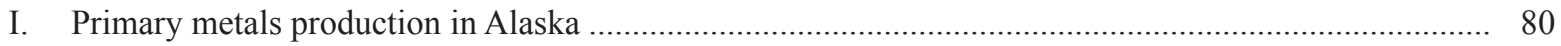

J. Production of industrial minerals, coal, and other commodities in Alaska ........................................... 81

\section{Figures}

1. Map showing regions of mineral activity in Alaska as described in this report

2. Graph showing exploration and development expenditures and the value of production of Alaska's mineral industry......

3. Charts illustrating mineral industry employment by category ……......................................................... 4

4. Graph showing total mineral industry employment ……........................................................................ 5

5. Graph showing Alaska mining employment ..................................................................................... 5

6. Graph showing mining industry revenue to State of Alaska and municipalities...................................... 7

7. Map showing selected mineral exploration projects in Alaska ........................................................... 10

8. Chart illustrating exploration expenditures in Alaska ......................................................................... 11

9. Chart illustrating exploration expenditures by commodity .............................................................. 12

10. Chart illustrating exploration expenditures by deposit type............................................................ 12

11. Chart illustrating exploration expenditures by region .......................................................................... 13

12. Map showing selected mineral development projects in Alaska....................................................... 23

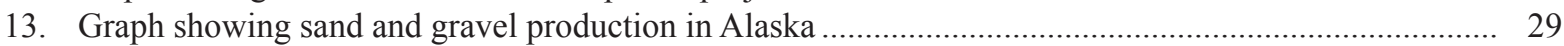

14. Graph showing amount and value of gold production in Alaska ......................................................... 29

15. Graph showing coal production in Alaska, including exports outside of Alaska .................................... 29

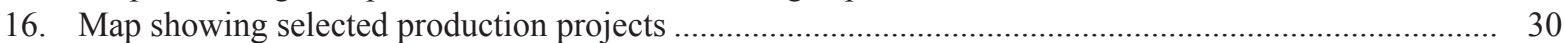

17. Chart illustrating Alaska mineral production value by commodity .................................................... 30

18. Graph showing Alaska international mineral exports ......................................................................... 33

19. Photo of Rich Hughes and others working the State of Alaska trade show booth at the Mineral Exploration Roundup.

Tables

1. Total value of the mineral industry in Alaska by year ........................................................................ 3

2. Estimated Alaska mine employment .............................................................................................. 4

3. Revenues paid to the State of Alaska and municipalities by Alaska's mineral industry ......................... 6

4. Alaska state annual claim rental rates by size and maturity ….............................................................. 7

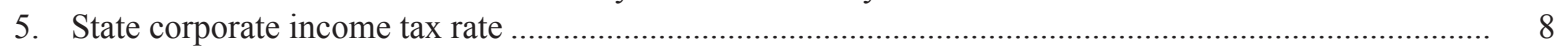

6. Reported exploration expenditures in Alaska by commodity....................................................... 11

7. Reported exploration expenditures and employment in Alaska ........................................................... 12

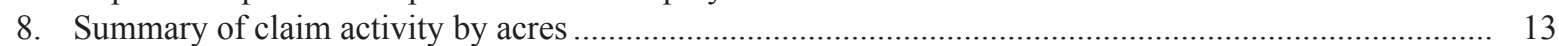

9. Reported mineral development expenditures and employment in Alaska by commodity and region ...... 21

10. Reported mineral development expenditures in Alaska by commodity .............................................. 22

11. Gold reserves and resources at Rock Creek, Big Hurrah, and various NovaGold holdings at Nome....... 24

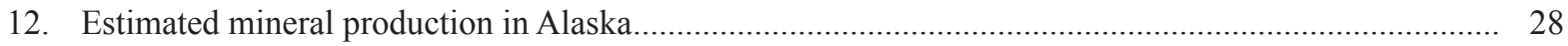




\section{CONTENTS}

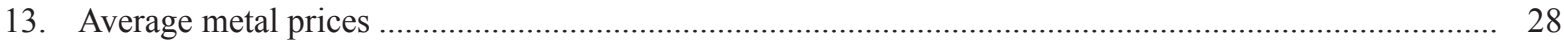

14. Reported refined gold production, number of operators, and industry employment.............................. 31

15. Production for selected Alaska placer gold mines.............................................................................. 31

16. Reported sand and gravel production and industry employment in Alaska by region............................. 32

17. Reported rock production and industry employment in Alaska by region ............................................ 32

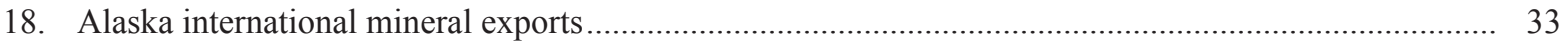

19. Reserves and resources by category at Red Dog Mine .................................................................. 33

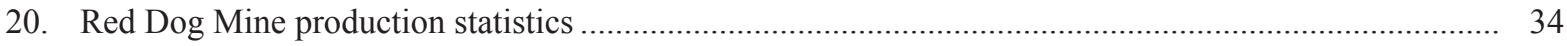

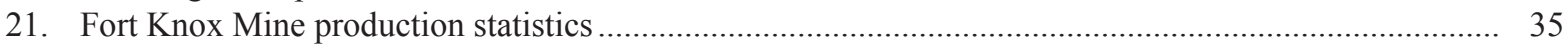

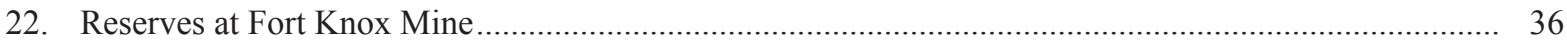

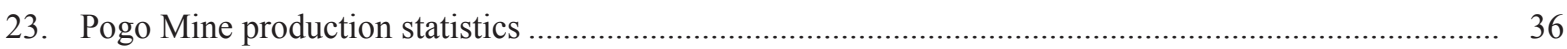

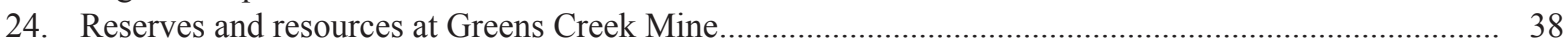

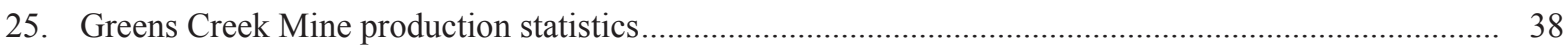

26. Companies reporting significant drilling programs in Alaska .......................................................... 39

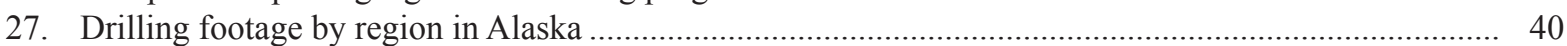

28. Drilling footage reported in Alaska ................................................................................................ 40

29. Detailed state airborne geophysical surveys and follow-up geologic ground-truth mapping ................. 42

30. Detailed federally funded airborne geophysical survey work contracted by DGGS ............................. 43 



\section{Alaska's Mineral Industry 2009 \\ D.J. Szumigala ${ }^{1}$, L.A. Harbo ${ }^{2}$ and R.A. Hughes ${ }^{3}$}

\section{INTRODUCTION}

Alaska has long been considered a frontier compared to most of North America and it still maintains that status with regard to mineral resources. The state's abundance of natural resources has drawn explorers for the past two centuries and remains the driving force in its economy. Juneau, Nome, Fairbanks, and other towns across the state were built around early mining camps, and mining remains a significant local source of employment, infrastructure, and government revenue. The unmatched geologic diversity of Alaska hosts a wide range of metallogenic settings and mineral commodities. The great mineral potential of the state is evident in past production from world-class deposits - placer gold from the Fairbanks and Nome mining districts; copper from the Jumbo, Bonanza, Erie, Mother Lode, and Green Butte mines in the Kennecott district; gold from the Alaska-Juneau and Treadwell mines near Juneau; and placer platinum from the Goodnews Bay mining district. Alaska's world-class deposits currently in production are Red Dog, Greens Creek, and Fort Knox mines. The Pebble, Donlin Creek, and Money Knob deposits indicate that there are still extremely large mineral deposits to be developed in Alaska; undoubtedly other worldclass Alaska mineral deposits remain to be discovered.

Alaska is strategically located along the Pacific Rim and offers prospective land, sanctity of title, a statesponsored geological and geophysical mapping effort, a reasonable permitting process, capable workforce, exploration incentives, and inventive infrastructure equity-sharing programs. More than 190 million acres of federal, state, and Native lands are open for mineralrelated activities and mining. It is the policy of the State of Alaska to encourage the settlement of its land and the development of its resources by making them available for maximum use consistent with the public interest.

The total value of Alaska's mineral industry in 2009 was \$2.964 billion, \$204.2 million and 6.5 percent lower than the 2008 value of $\$ 3.1706$ billion. The decline in total value primarily is explained by lower metal prices, increased operating costs, and a worldwide economic slowdown. Table 1 shows the estimated annual value of the mineral industry in Alaska from 1981 through 2009, as divided between exploration and development investments, and the gross value of the mineral products. This total value, although it is a combination of expenses and receipts, is an effective way of tracking the annual strength of the mineral industry and reflects the amount of capital invested in Alaska. The year 2009 was the 14 th consecutive year with a total value exceeding \$1 billion and the fourth consecutive year with production value above $\$ 2$ billion.

Exploration activities continued for a wide variety of commodities across all regions of Alaska, with new discoveries and expansion of recently announced mineral resources. Exploration expenditures were $\$ 180.0$ million in 2009, a 48 percent decrease from the $\$ 347.3$ million expended in 2008. The year 2009 was the fifth consecutive year with expenditures of more than $\$ 100$ million. Development expenditures in Alaska declined in 2009 to approximately $\$ 330.8$ million from $\$ 396.2$ million in 2008, a nearly 17 percent decrease, and 2009 was the sixth year with development expenditures above \$200 million. Mineral production volumes increased for most metals; however, declining prices for most metals subdued production values. The value of mineral production in 2009 increased more than 1 percent, to $\$ 2,455.6$ million, from $\$ 2,427.1$ million in 2008 .

Figure 1 shows the regions of the state as defined for this report. Table 1 and figure 2 show the estimated value of the mineral industry in Alaska per year from 1981 through 2009, as divided between exploration and development investments, and the gross value of mineral products. Company information is generally used to define the exploration and development parameters. Average metal prices are calculated from the daily London PM closing price for gold, and from the average weekly spot price on the London Metal Exchange for the other metals. It is important to note that these prices are used to calculate the value of metals produced in the state, but do not take into account the costs of min-

\footnotetext{
${ }^{1}$ Alaska Division of Geological \& Geophysical Surveys, 3354 College Rd., Fairbanks, Alaska 99709-3707; david.szumigala@alaska.gov ${ }^{2}$ Alaska Division of Economic Development, 211 Cushman St., Fairbanks, Alaska 99701.

${ }^{3}$ Formerly Alaska Division of Economic Development; present address R.A. Hughes \& Associates, 318 Juneau Ave., Fairbanks, AK 99701-3768.
} 
Figure 1. Regions of mineral activity as described in this report.

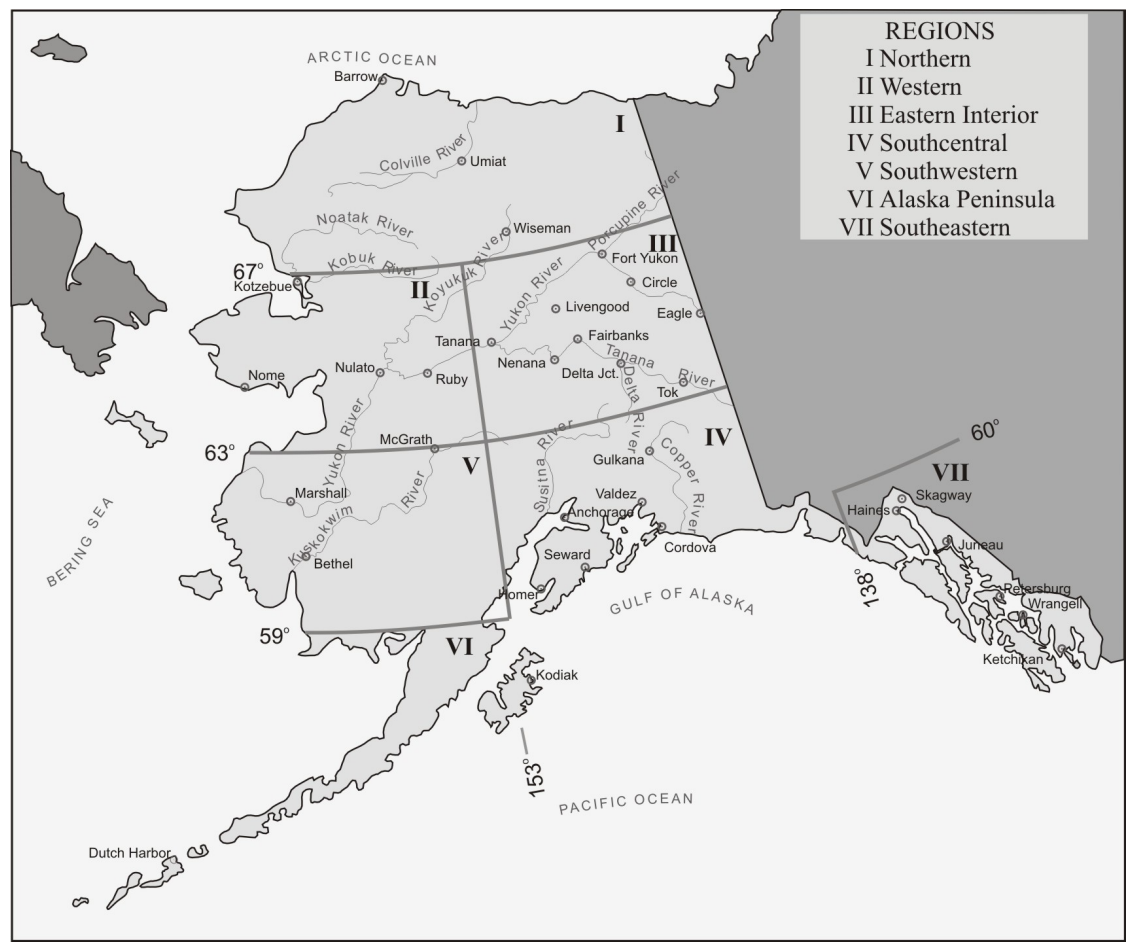

ing or transportation, or smelter charges and penalties. Coal prices are estimated from average coal prices for similar grade material around the Pacific Rim. Industrial material prices are based on regional rates provided by some operators.

Please note that the formatting and presentation of data in some tables has changed compared to previous editions of this report, reflecting changes in data collected and accounting practices by the mining industry. Whenever possible, the authors have worked to maintain consistency of data for seamless year-to-year comparisons. Most changes are noted in footnotes in the affected tables.

This summary of Alaska's mineral industry activity for 2009 is the 29th in the series of annual reports, and is made possible by information provided through press releases, company annual and financial reports, phone interviews, other research, and replies to questionnaires mailed by the Alaska Division of Geological \& Geophysical Surveys (DGGS). This report is part of a cooperative venture between DGGS and the Division of Economic Development in the Department of Commerce, Community and Economic Development (Commerce). Commerce provides the funding to print the report. Information in this report supersedes data previously published in DGGS Information Circular 60.

\section{EMPLOYMENT}

Figure 3 displays employment within various segments of Alaska's mineral industry. Table 2 lists estimated employment in the Alaska minerals industry for the past nine years and figure 4 shows the trends in that employment from 2000 through 2009. Total minerals industry employment in 2009 is estimated to be 3,280 full-time-equivalent jobs, a decrease of 112 jobs (3.3 percent) from the estimated 2008 total of 3,392 fulltime-equivalent jobs. The largest change in employment compared to 2008 was the drop in mineral development jobs from 516 to 371, a 28 percent decrease. Exploration jobs also decreased from 546 jobs in 2008 to 422 in 2009, a 23 percent decrease.

Mineral production employment increased significantly in 2009 , with 2,487 jobs across all production sectors in 2009 compared to 2,330 jobs in 2008 . Lode gold mining jobs increased 13 percent in 2009, adding 93 jobs. Placer gold mining employment also increased significantly in 2009, with 123 full-time-equivalent jobs added to the 312 jobs estimated for 2008 , a 39 percent increase. The high price of gold was the most significant factor in the increase in gold miners and likely influenced the increase in recreational miners reported from 2008 to 2009. Full-time-equivalent jobs decreased in the basemetals sector by 62 jobs, or 13 percent, from 2008 to 2009. Modest employment increases were seen in the polymetallic, and sand and gravel mining sectors.

The average monthly wage for mining in Alaska during 2009 was $\$ 7,588$, according to the Alaska Department of Labor \& Workforce Development (DLWD), compared to an average monthly wage for all industries in Alaska of $\$ 3,886$. Mining jobs in Alaska have higher 
Table 1. Total value of the mineral industry in Alaska by year (in millions of U.S. dollars).

\begin{tabular}{|c|c|c|c|c|c|c|c|}
\hline \multirow{2}{*}{$\begin{array}{l}\text { Year } \\
1981\end{array}$} & \multicolumn{2}{|c|}{$\begin{array}{c}\text { Exploration } \\
\text { (expenditure) }\end{array}$} & \multicolumn{2}{|c|}{$\begin{array}{l}\text { Development } \\
\text { (expenditure) }\end{array}$} & $\begin{array}{c}\text { Production } \\
\text { (value) }\end{array}$ & \multicolumn{2}{|c|}{$\begin{array}{c}\text { Total } \\
\text { (calculated) }\end{array}$} \\
\hline & $\$$ & 76.3 & $\$$ & 24.7 & 188.6 & $\$$ & 289.6 \\
\hline 1982 & & 45.6 & & 41.6 & 196.4 & & 283.6 \\
\hline 1983 & & 34.1 & & 27.9 & 212.4 & & 274.4 \\
\hline 1984 & & 22.3 & & 53.4 & 199.4 & & 275.1 \\
\hline 1985 & & 9.2 & & 34.1 & 226.6 & & 269.9 \\
\hline 1986 & & 8.9 & & 24.3 & 198.5 & & 231.7 \\
\hline 1987 & & 15.7 & & 100.3 & 202.4 & & 318.4 \\
\hline 1988 & & 45.5 & & 275.0 & 232.2 & & 552.7 \\
\hline 1989 & & 47.8 & & 134.3 & 277.0 & & 459.1 \\
\hline 1990 & & 63.3 & & 14.3 & 533.0 & & 610.6 \\
\hline 1991 & & 39.9 & & 25.6 & 546.5 & & 612.0 \\
\hline 1992 & & 30.2 & & 29.6 & 560.8 & & 620.6 \\
\hline 1993 & & 30.3 & & 27.7 & 448.7 & & 506.7 \\
\hline 1994 & & 31.1 & & 45.0 & 507.5 & & 583.6 \\
\hline 1995 & & 34.3 & & 148.6 & 537.2 & & 720.1 \\
\hline 1996 & & 44.7 & & 394.0 & 590.4 & & $1,029.1$ \\
\hline 1997 & & 57.8 & & 168.4 & 936.2 & & $1,162.4$ \\
\hline 1998 & & 57.3 & & 55.4 & 921.2 & & $1,033.9$ \\
\hline 1999 & & 52.3 & & 33.8 & $1,032.9$ & & $1,119.0$ \\
\hline 2000 & & 34.9 & & 141.7 & $1,106.4$ & & $1,283.0$ \\
\hline 2001 & & 23.8 & & 81.2 & 917.3 & & $1,022.3$ \\
\hline 2002 & & 26.5 & & 34.0 & $1,012.8$ & & $1,073.3$ \\
\hline 2003 & & 27.6 & & 39.1 & $1,000.7$ & & $1,067.4$ \\
\hline 2004 & & 70.8 & & 209.1 & $1,338.7$ & & $1,618.6$ \\
\hline 2005 & & 103.9 & & 347.9 & $1,401.6$ & & $1,853.4$ \\
\hline 2006 & & 178.9 & & 495.7 & $2,858.2$ & & $3,532.8$ \\
\hline 2007 & & 329.1 & & 318.8 & $3,367.0$ & & $4,014.9$ \\
\hline 2008 & & 347.3 & & 396.2 & $2,427.1$ & & $3,170.6$ \\
\hline 2009 & & 180.0 & & 330.8 & $2,455.6$ & & $2,966.4$ \\
\hline TOTAL & $\$$ & $2,069.4$ & $\$$ & $4,052.5$ & $\$ 26,433.3$ & & $32,555.2$ \\
\hline
\end{tabular}

Source: Alaska's Mineral Industry reports published annually by DGGS/ Commerce.

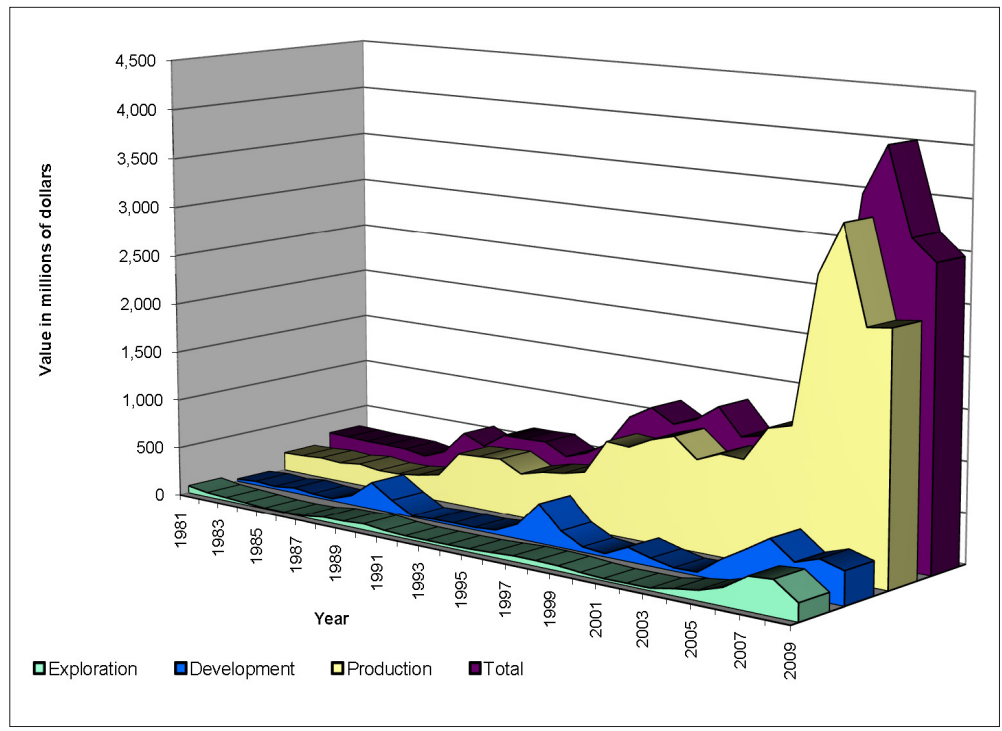

wages than any other industry except oil and gas. The average annual earnings for a mining job were $\$ 91,100$ in 2009, according to DLWD. Mining jobs pay nearly twice the Alaskan average annual earnings of $\$ 46,600$. Mining wages in Alaska totaled $\$ 183,375,314$ in 2009 . The agency reported that there were 2,126 mining jobs in Alaska in 2009, with total employment in all industries in Alaska during 2009 at 320,265 jobs. Mining employment was reported in most regions of Alaska, with 685 jobs in the Fairbanks North Star Borough, 380 jobs in the Anchorage municipality, and 281 jobs in the City and Borough of Juneau. During the last 10 years, according to the DLWD, employment growth by Alaska's mining industry has outpaced growth of the United States' aggregate mining industry employment by nearly 40 percent; expansions in Alaska's mining industry employment have also eclipsed employment growth in most of Alaska's other private industries. The DLWD statistics do not include the self employed, such as the majority of placer operators; their employment data also does not often include jobs in the exploration and development phases of mining. Jobs in these mining phases are often grouped by the DLWD in the engineering, environmental, or construction industries. Consequently, mining's contributions to employment and earnings in Alaska could be underestimated.

The average monthly wage for metal mining in Alaska during 2009 was $\$ 7,795$, according to the DLWD. They also report that the average employment during 2009 was 1,767 full-time-equivalent jobs in metal mining, more than 300 in coal mining and nonmetallic mineral mining and quarrying, and 9,321 in support activities for mining, oil, and gas.

Figure 2. Alaska's mineral industry total value, 1981-2009. 


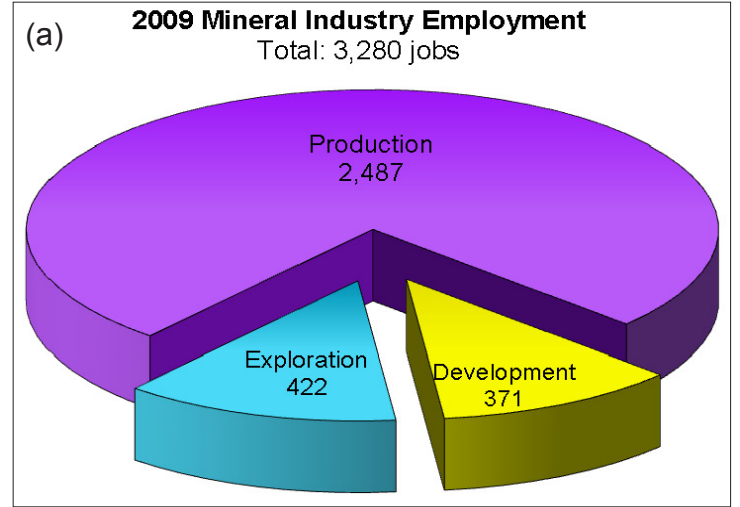

Figure 3. 2009 mineral industry employment in Alaska by (a) category and (b) sector and commodity.

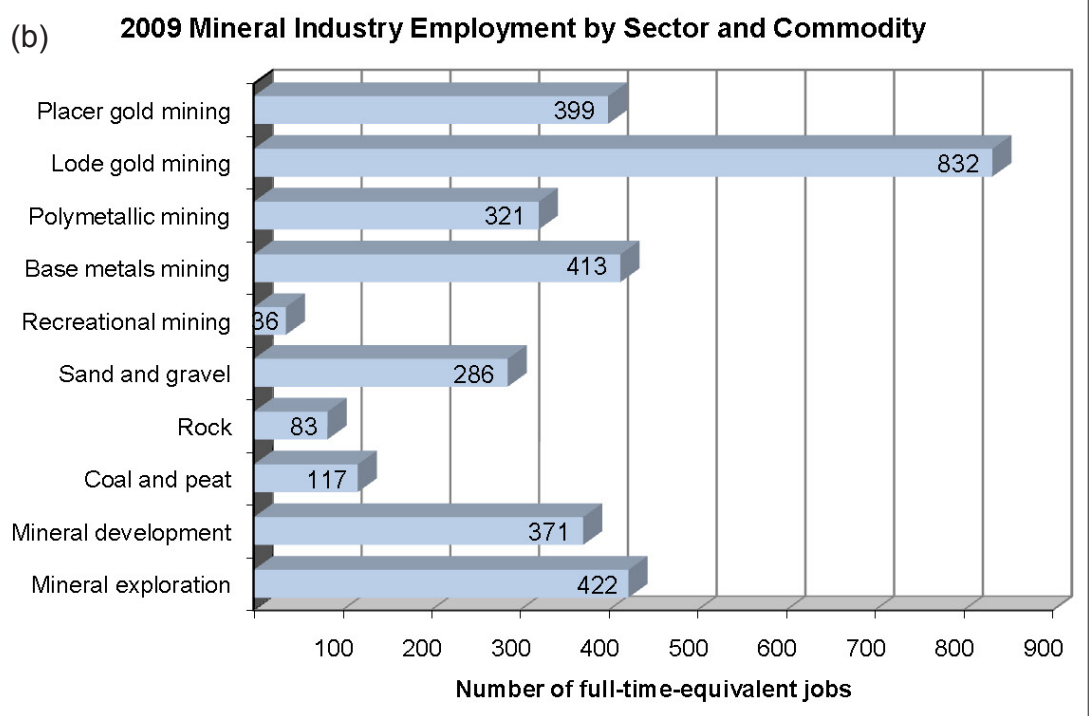

Table 2. Estimated Alaska mine employment, 2001-2009a.

\begin{tabular}{lrrrrrrrrr} 
& $\mathbf{2 0 0 1}$ & $\mathbf{2 0 0 2}$ & $\mathbf{2 0 0 3}$ & $\mathbf{2 0 0 4}$ & $\mathbf{2 0 0 5}$ & $\mathbf{2 0 0 6}$ & $\mathbf{2 0 0 7}$ & $\mathbf{2 0 0 8}$ & $\mathbf{2 0 0 9}$ \\
Gold/silver mining & & & & & & & & & \\
$\quad$ Placer & 176 & 148 & 82 & 64 & 86 & 242 & 208 & 282 & 399 \\
$\quad$ Lode & 337 & 413 & 325 & 433 & 411 & 704 & 808 & 739 & 832 \\
Polymetallic mining & 275 & 262 & 295 & 265 & 250 & 245 & 276 & 317 & 321 \\
Base metals mining & 559 & 580 & 388 & 508 & 449 & 457 & 457 & 475 & 413 \\
Recreational mining & 210 & 180 & 175 & 175 & 175 & 45 & 54 & 30 & 36 \\
Sand and gravel & 556 & 702 & 349 & 567 & 400 & 337 & 284 & 277 & 286 \\
Rock & 137 & 177 & 35 & 475 & 148 & 104 & 124 & 93 & 83 \\
Coal and peatb,c & 153 & 121 & 85 & 94 & 101 & 106 & 113 & 117 & 117 \\
Tin, jade, soapstone, & & & & & & & -- & -- & -- \\
$\quad$ ceramics, platinum & 20 & 20 & 20 & -- & -- & - & - \\
Mineral development & 333 & 135 & 64 & 283 & 498 & 848 & 735 & 516 & 371 \\
Mineral exploration & 79 & 86 & 88 & 184 & 303 & 435 & 499 & 546 & 422 \\
\hline TOTAL & $\mathbf{2 , 8 3 5}$ & $\mathbf{2 , 8 2 4}$ & $\mathbf{1 , 9 0 6}$ & $\mathbf{3 , 0 4 8}$ & $\mathbf{2 , 8 2 1}$ & $\mathbf{3 , 5 2 3}$ & $\mathbf{3 , 5 5 8}$ & $\mathbf{3 , 3 9 2}$ & $\mathbf{3 , 2 8 0}$
\end{tabular}

${ }^{a}$ Reported man-days are calculated on a 260-day work year to obtain average annual employment unless actual average annual employment numbers are provided.

${ }^{b}$ This figure does not include all of the man-days associated with peat operations; most of those man-days are included in sand and gravel numbers.

${ }^{c}$ Coal and peat figures were combined in 2009 to maintain confidentiality.

- - = Not reported. 


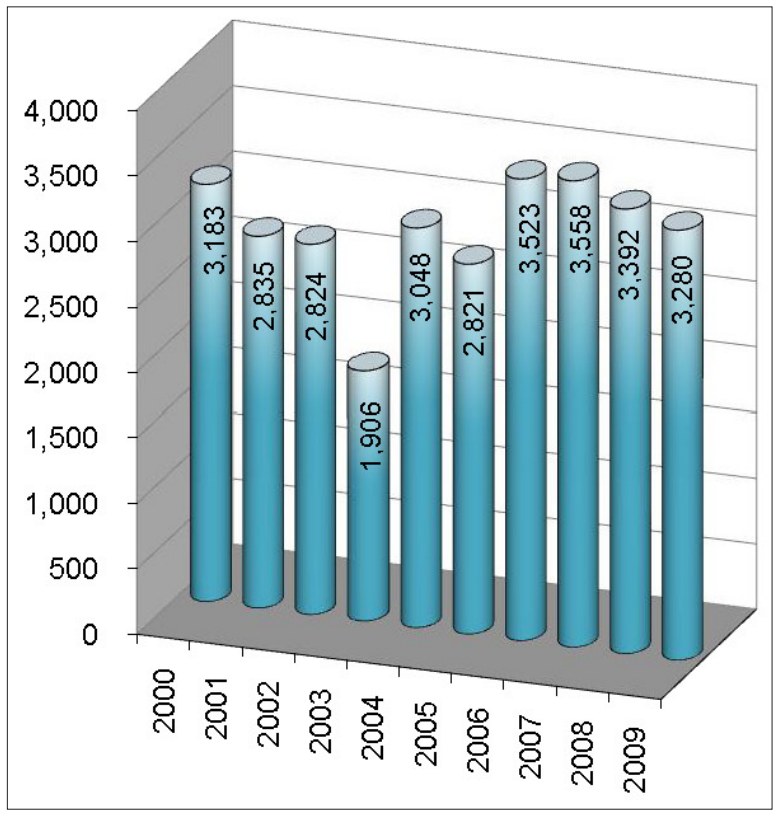

Figure 4. Total mineral industry employment in Alaska from 2000 through 2009.

Nonmetallic mineral product manufacturing provided 328 jobs, including an average of 315 jobs in cement and concrete manufacturing for 2009. Primary metal manufacturing provided 23 full-time-equivalent jobs, while metal and mineral merchant wholesalers provided an average of 114 jobs during 2009.

Nearly three-quarters of all wage and salary earnings from mining stay within the state, according to the DLWD, because Alaska residents comprise threequarters of all workers in the mining industry. Mining wages for Alaska residents totaled more than $\$ 145.3$ million in 2009. Workers in the mining industry live in 26 of Alaska's 29 boroughs and census areas, and they often reside in a different borough or census area than where they work. Mines are often the largest, or among the largest, employers in their borough or census area. Mines are also located in remote areas of the state where other employment opportunities are scarce, with half of all mining jobs, as tabulated by the DLWD, located in rural Alaska (fig. 5).

Labor \& Workforce Development statistics are collected using different methods than the employment figures collected for this report; thus there is no direct correlation between the two sets of employment figures. For example, the DLWD mining employment and wage statistics are based on 77 reporting units (companies) consisting of one coal, 42 metal ore, and 34 nonmetallic mineral, quarrying units.

In 2009, Greens Creek, Red Dog, and Pogo mines were the largest employers in Juneau, the Northwest Arctic Borough, and Southeast Fairbanks Census Area, respectively. Fort Knox Mine and Usibelli Coal Mine are both the third-largest employers in their respective boroughs. Kensington Mine will likely become one of the top ten private employers in Juneau by 2011.

The Alaska mining industry also created an estimated 1,900 indirect jobs, according to a 2009 study prepared for the Alaska Miners Association Inc. by the McDowell Group Inc. Mining companies strengthen Alaska's local economies by employing Alaska residents from more than 120 Alaska communities and by purchasing supplies and services from hundreds of Alaska businesses.

\section{GOVERNMENT REVENUES FROM ALASKA'S MINERAL INDUSTRY}

Revenues are paid to the State of Alaska by the minerals industry through a number of instruments. Those instruments include State claim rentals, production royalties, annual labor, coal land rentals, coal royalties, material (rock, sand, and gravel) sales from state and mental health trust and State Pipeline Coordinator's Office managed lands, miscellaneous fees, state fuel taxes, corporate income taxes, and mining license taxes. Municipalities also receive revenues from the minerals industry for property taxes, payments in lieu of taxes (PILT), severance taxes, and sales taxes. The total revenues paid to the state and municipalities for 2009 amounted to more than $\$ 70.2$ million (this number will be revised by the figure for State corporate income tax; that figure was not available at time of printing), an increase from the $\$ 67.9$ million paid in 2008. See table 3 for an itemized listing of revenues paid. The 2009 revenues are incomplete because 2009 corporate income tax data was not available for this publication.

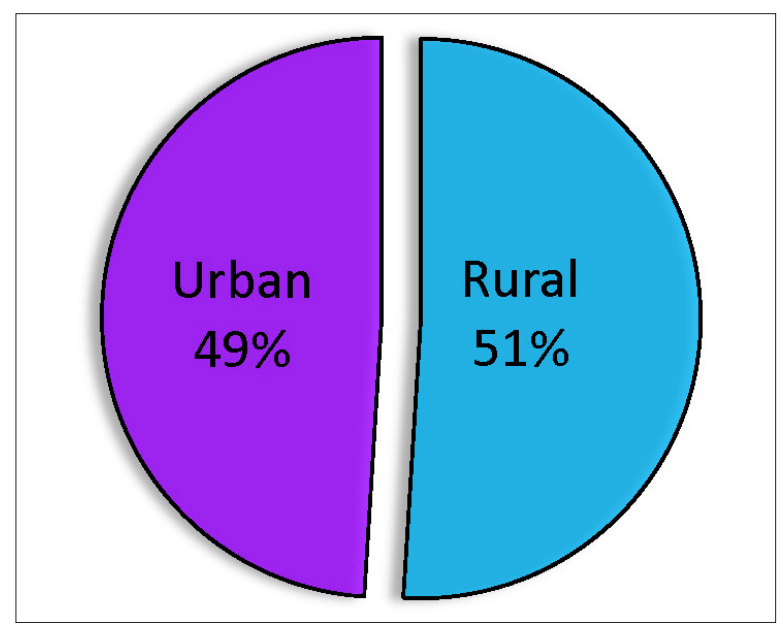

Figure 5. Alaska mining employment, 2009. Note Urban Alaska includes Anchorage, Fairbanks North Star Borough, and Juneau. Source: Alaska Department of Labor and Workforce Development, Research and Analysis Section. 
Revenues to the State of Alaska and municipalities from mineral-industry-specific fees, rent, sales, royalties, and taxes are shown in figure 6 .

State mineral and coal rents and royalties amounted to $\$ 6,441,734$ during 2009 compared to $\$ 6,629,451$ for 2008. Details of the payments by item are shown in table 3. The State of Alaska mining laws grant the holder of a mining claim exclusive right to the locatable minerals in the ground covered by that mining claim. State mining claims have recording, rental, and other fees associated with them. Mining claim location certificates and recording fees must be recorded in the recording district office in which the claim is located within 45 days of the posting date. Recording fees change from time to time and

Table 3. Revenues paid to the State of Alaska and municipalities by Alaska's mineral industry, 2004-2009.

\begin{tabular}{|c|c|c|c|c|c|c|}
\hline & 2004 & 2005 & 2006 & 2007 & 2008 & 2009 \\
\hline \multicolumn{7}{|l|}{ State mineral rents and royalties ${ }^{a}$} \\
\hline $\begin{array}{l}\text { State claim rentals } \\
\text { Production royalties } \\
\text { Annual labor } \\
\text { Subtotal }\end{array}$ & $\begin{array}{r}\$ 2,657,939 \\
162,637 \\
226,191 \\
\text { \$ } \mathbf{3 , 0 4 6 , 7 6 7}\end{array}$ & $\begin{array}{r}\$ 3,308,752 \\
124,338 \\
332,439 \\
\$ \mathbf{3 , 7 6 5 , 5 2 9}\end{array}$ & $\begin{array}{rr}\$ 3,460,803 \\
171,220 \\
155,007 \\
\\
\$ \mathbf{3 , 7 8 7 , 0 3 0}\end{array}$ & $\begin{array}{r}\$ 4,649,795 \\
800,548 \\
163,279 \\
\mathbf{\$ 5 , 6 1 3 , 6 2 2}\end{array}$ & $\begin{array}{r}\$ \quad 3,082,071 \\
1,518,622 \\
380,169 \\
\mathbf{4 , 9 8 0 , 8 6 2}\end{array}$ & $\begin{array}{r}\$ 3,295,631 \\
1,368,526 \\
482,858 \\
\$ \mathbf{5 , 1 4 7 , 0 1 5}\end{array}$ \\
\hline \multicolumn{7}{|l|}{ State coal rents and royalties } \\
\hline $\begin{array}{l}\text { Rents } \\
\text { Royalties } \\
\text { Bonus } \\
\text { Subtotal }\end{array}$ & $\begin{array}{r}236,532 \\
1,239,257 \\
- \\
- \\
\$ \mathbf{1 , 4 7 5 , 7 8 9}\end{array}$ & $\begin{array}{r}257,112 \\
1,476,250 \\
129,880 \\
\mathbf{\$ 1 , 8 6 3 , 2 4 2}\end{array}$ & $\begin{array}{r}337,764 \\
1,473,948 \\
10 \\
\text { \$ } \mathbf{1 , 8 1 1 , 7 2 2} \$\end{array}$ & $\begin{array}{r}253,376 \\
1,443,050 \\
- \\
1,696,426\end{array}$ & $\begin{array}{r}248,841 \\
1,399,748 \\
- \\
\text { \$ } 1,648,589\end{array}$ & $\begin{array}{r}374,433 \\
920,286 \\
- \\
\text { \$ } 1,294,719\end{array}$ \\
\hline \multicolumn{7}{|l|}{ State material Sales } \\
\hline $\begin{array}{l}\text { Mental Health } \\
\text { Division of Land } \\
\text { SPCO } \\
\text { Subtotal }\end{array}$ & $\begin{array}{r}76,267 \\
467,360 \\
112,047 \\
\$ \quad \mathbf{6 5 5 , 6 7 4}\end{array}$ & $\begin{array}{r}129,409 \\
944,905 \\
46,877 \\
\text { \$ } \mathbf{1 , 1 2 1 , 1 9 1}\end{array}$ & $\begin{array}{r}89,634 \\
1,582,769 \\
118,904 \\
\$ \quad \mathbf{1 , 7 9 1 , 3 0 7}\end{array}$ & $\begin{array}{r}24,835 \\
2,615,810 \\
57,056 \\
\mathbf{\$} \mathbf{2 , 6 9 7 , 7 0 1}\end{array}$ & $\begin{array}{r}37,734 \\
2,818,107 \\
182,237 \\
\mathbf{\$} \mathbf{3 , 0 3 8 , 0 7 8}\end{array}$ & $\begin{array}{r}170,996 \\
4,323,601 \\
179,875 \\
\$ \quad \mathbf{4 , 6 7 4 , 4 7 2}\end{array}$ \\
\hline \multicolumn{7}{|l|}{ State mining miscellaneous fees } \\
\hline $\begin{array}{l}\text { Filing fees } \\
\text { Penalty fees } \\
\text { Explore incentive app filing fee } \\
\text { Bond pool payment } \\
\text { Surface coal mining app fee } \\
\text { APMA mining fees } \\
\text { Subtotal }\end{array}$ & $\begin{array}{r}1,300 \\
26,110 \\
- \\
35,426 \\
3,116 \\
14,550 \\
\mathbf{8 0 , 5 0 2}\end{array}$ & $\begin{array}{r}8,465 \\
20,280 \\
- \\
32,331 \\
3,150 \\
17,131 \\
\mathbf{8 1 , 3 5 7}\end{array}$ & $\begin{array}{r}965 \\
46,249 \\
- \\
36,721 \\
10,897 \\
17,475 \\
\mathbf{1 1 2 , 3 0 7}\end{array}$ & $\begin{array}{r}1,750 \\
24,005 \\
- \\
43,909 \\
10,458 \\
\\
20,877 \\
\mathbf{\$} \quad \mathbf{1 0 0 , 9 9 9}\end{array}$ & $\begin{array}{r}2,750 \\
18,876 \\
- \\
39,429 \\
3,023 \\
23,811 \\
\mathbf{8 7 , 8 8 9}\end{array}$ & $\begin{array}{r}1,787 \\
115,819 \\
- \\
70,548 \\
1,800 \\
19,519 \\
\mathbf{\$} \quad \mathbf{2 0 9 , 4 7 3}\end{array}$ \\
\hline $\begin{array}{l}\text { AIDEA - Facilities use fees } \\
\text { State Fuel Taxes } \\
\text { State corporate income tax } \\
\text { Mining License Tax }{ }^{d-f} \\
\text { State Total }\end{array}$ & $\begin{array}{r}2,104,144 \\
10,317,238 \\
\mathbf{\$ 3 3 , 4 1 0 , 1 1 4}\end{array}$ & $\begin{array}{r}23,641,883 \\
18,637,996 \\
\mathbf{\$ 6 4 , 7 1 8 , 1 9 8}\end{array}$ & $\begin{array}{c}71,299,684 \\
79,141,526 \\
\mathbf{\$ 1 7 3 , 4 1 9 , 5 7 6}\end{array}$ & $\begin{array}{c}16,218,000 \\
726,563 \\
61,331,540 \\
54,408,227 \\
\mathbf{\$ 1 4 2 , 7 9 3 , 0 7 8}\end{array}$ & $\begin{array}{r}16,190,000 \\
428,214 \\
12,919,787 \\
16,044,139 \\
\mathbf{\$ 5 5 , 3 3 7 , 5 5 8}\end{array}$ & $\begin{array}{r}15,918,000 \\
877,952 \\
\mathrm{~N} / \mathrm{A}^{\mathrm{c}} \\
29,725,100 \\
\mathbf{\$ 5 7 , 8 4 6 , 7 3 1}\end{array}$ \\
\hline Payments to Municipalities & $\$ 10,999,663$ & $\$ 11,975,892$ & $\$ 14,388,329$ & $\$ 15,827,501$ & $\$ 12,599,399$ & $\$ 12,387,540$ \\
\hline TOTAL ${ }^{g}$ & $\$ 44,409,777$ & $\$ 76,694,090$ & $\$ 187,807,905$ & $\$ 158,620,579$ & $\$ 67,936,957$ & $\$ 70,234,271$ \\
\hline
\end{tabular}

${ }^{a}$ Includes upland lease and offshore lease rentals.

${ }^{\mathrm{b}}$ Reported on a cash basis - payments actually received during the given year.

'Preliminary data not available for 2009.

Only subchapter $\mathrm{C}$ corporations pay income tax.

- This report may not reflect $100 \%$ of the returns received in a year.

Data from 2004 through 2008 has been updated to reflect revenue to the state for the succeeding fiscal year; ex.: FY 07 receipts are shown in calendar year 2006.

'Includes metals, coal, and material.

'Mining license tax has been adjusted to reflect actual receipts for the succeeding fiscal year for the period 2003 to 2008; see note for income tax above.

f2009 numbers are preliminary and are subject to revision.

g2009 total is incomplete and will be revised. 


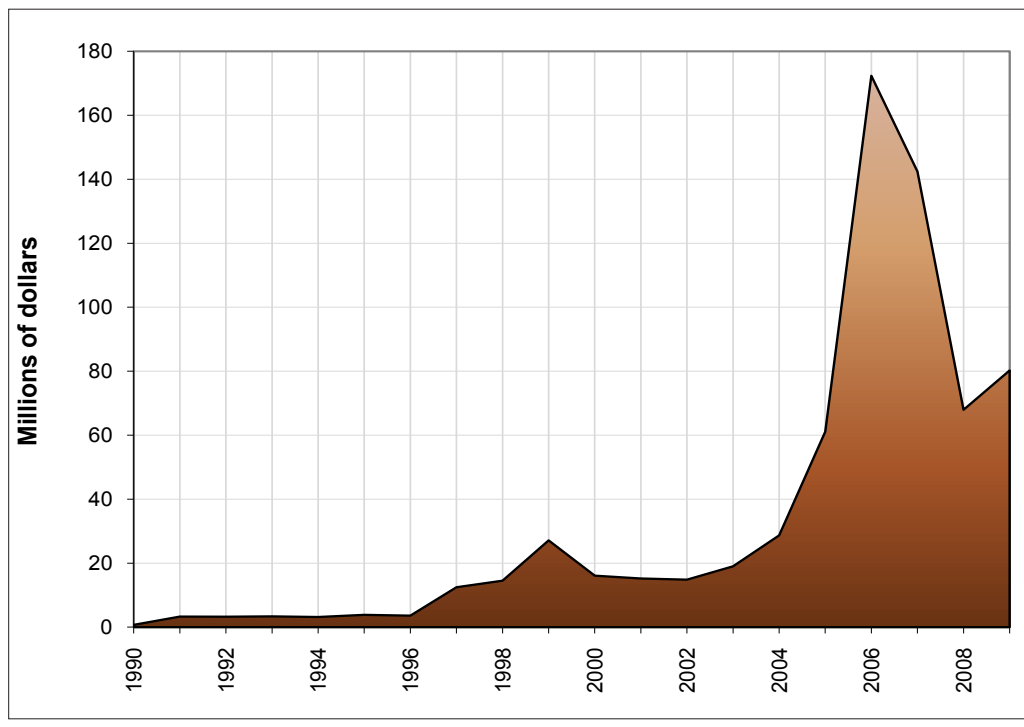

Figure 6. Mining industry revenue to State of Alaska and municipalities from 1990 to 2009.

the Recorder's Office should be contacted for the correct fee; recording fees are also posted at the following web site address: http://dnr.alaska.gov/ssd/recoff/fees.cfm. Rental fees under regulation 11 AAC 86.215 are shown in table 4, and must be paid according to the instructions on the back of the certificate form.

Annual rental fees for State mining claims, leasehold locations, upland mining leases, offshore mining leases, and prospecting sites increased in 2009. Alaska Statute directs DNR to revise the annual rental rates to match the changes in the Consumer Price Index (CPI) for Anchorage as compiled by the U.S. Department of Labor. The statute requires DNR to make the revisions every ten years, so the more than 60 percent increase in 2009 represents ten years increase to the CPI. The new rates began for mining claim payments due November 30 , 2009, which cover mining claims for the "mining fiscal year" that runs September 1, 2009, through August 31, 2010. The first rental payment covers the period from the date of posting the claim to the following September 1st. Annual labor must be performed on a mining claim each year. The annual lease rate for coal properties is $\$ 3.00$ per acre. The rental payments may be credited against royalties to the extent that they do not exceed the royalties.
In 1989, the Alaska State Legislature enacted a new production royalty law, Alaska Statute 38.05.212, which requires holders of state mining locations to pay a production royalty on all revenues received from minerals produced on state land. The production royalty requirement applies to all revenues received from minerals produced from a state mining claim or mining lease during each calendar year. Payment of royalty is in exchange for and to preserve the right to extract and possess the minerals produced. The production royalty is 3 percent of the net income as determined under the Mining License Tax Law AS 43.65 and regulation 15 AAC 65. Department of Natural Resources regulations 11 AAC 86.760-796 provide details regarding the production royalty requirements.

The state sells rock, sand, and gravel from its lands at a prescribed rate for use in construction. Lands involved in those sales include Mental Health Land Trust, Division of Lands, and State Pipeline Coordinator's Office (SPCO). Sales of these materials generated $\$ 4,674,472$ during 2009, compared to $\$ 3,038,078$ during 2008 . Other common variety minerals that could be involved in this category include riprap, limestone, slate, peat, and any other substances from the ground that are not designated through the location system for mining claims

Table 4. Alaska state annual claim rental rates by size and maturity. Rental rates were adjusted in 2009 in accordance with the Consumer Price Index for Anchorage as prescribed by statute AS 38.05.211.

\begin{tabular}{lccc}
$\begin{array}{l}\text { Years Since } \\
\text { Location }\end{array}$ & $\begin{array}{c}\text { Rental Per Quarter } \\
\text { Section Size Claim }\end{array}$ & $\begin{array}{c}\text { Rental Per Traditional Quarter- } \\
\text { Quarter Section Size Claim }\end{array}$ & $\begin{array}{c}\text { Rental for All Leases } \\
\text { (per acre fee) }\end{array}$ \\
\hline $0-5$ & $\$ 140$ & $\$ 35$ & $\$ 0.88$ \\
$6-10$ & $\$ 280$ & $\$ 70$ & $\$ 1.75$ \\
11 or more & $\$ 680$ & $\$ 170$ & $\$ 4.25$
\end{tabular}


(for example, gold, silver, and other metals) or leasing (for example, energy minerals such as coal, oil, and gas). Materials are measured and sold by the cubic yard. The price charged for materials depends on the type, or size, of sale, but prices are based on a competitive or fair market price of material in the area. Contact the DNR information office for further information (see Appendix F for contact information).

Claim and leaseholders on state land are assessed miscellaneous fees; these amounted to \$209,473 in 2009 compared to $\$ 87,889$ in 2008 . Miscellaneous fees are segregated in table 3 and comprise filing fees, penalties, exploration incentive application fees, bond pool payments, surface coal mining application fees, and Annual Placer Mining Application (APMA) fees.

Fuel tax collected by the State for 2009 amounted to $\$ 877,952$, compared to $\$ 428,214$ during 2008 . These numbers were collected from mining companies and are likely not entirely complete. The motor fuel tax was suspended for one year on September 1, 2008. The motor fuel tax is \$0.08/gallon and is collected for all fuel for mining operations. Fuel used for heating and stationary power plant is not taxable and application for refund of the full amount may be made to the State of Alaska. Off-highway fuel use for equipment and vehicles, mobile power plants, pumps, and unlicensed vehicle operation is partially refundable at the rate of $\$ 0.06 /$ gallon of gasoline or diesel fuel.

The Mining License Tax was established by statute (AS 43.65) to collect taxes on net income from mining operations after a 3.5 year initial production grace period provided to taxpayers to help return their initial investment. The rates on mining net income are as follows: No tax if net income is $\$ 40,000$ or less; $\$ 1,200$ plus 3 percent if over $\$ 40,000 ; \$ 1,500$ plus 5 percent if over $\$ 50,000$; and $\$ 4,000$ plus 7 percent if over $\$ 100,000$. The total Mining License Tax collected for 2009 was $\$ 29,725,100$, compared to $\$ 16,044,139$ in 2008 . Mining License Tax returns are confidential and cannot be reported by individual/entity.

Corporate income taxes are assessed on all corporations having net income from mining operations in the state. The preliminary total for corporate income tax collected by the state during 2009 from mining operations was not available at press time. The corporate income taxes collected from mining in 2008 amounted to $\$ 12,919,787$. Corporate income taxes are confidential and can't be reported by individual corporation. The corporate income tax rate is set by statute and is shown in table 5.

Mining companies were the largest taxpayers in the City and Borough of Juneau and the Fairbanks North Star Borough. Red Dog Mine paid \$6.7 million to the Northwest Arctic Borough in 2009 as Payment in Lieu of Taxes. Mining companies contributed to the Denali Borough through PILT and severance tax payments. The Alaska Industrial Development \& Export Authority (AIDEA) was paid annual user fees of $\$ 15.9$ million for use of the State-owned road and port, the DeLong Mountain Regional Transportation System, by Teck Alaska Inc., operator of the Red Dog Mine, and for use of the Skagway Ore Terminal by Minto Explorations Ltd., subsidiary of Capstone Mining Corp. (formerly Sherwood Copper Corp.).

\section{ACKNOWLEDGMENTS}

This report on Alaska's mineral industry is intended to provide current, accurate, and technically reliable information. The authors wish to thank all companies, agencies, and individuals that responded to the questionnaires or phone calls and provided information about their activities and operations. Without their voluntary and timely information this report would not be possible. DGGS mailed and emailed more than 700 questionnaires in December 2009 and continued sending additional questionnaires through 2010 . We received 115 responses and followed questionnaire requests with phone calls and other means of contact. Dave Szumigala (DGGS), Rich Hughes (Commerce), and Lisa Harbo (Commerce) prepared the body of the text, tables, graphic illustrations, and appendices with information supplied by many individuals. Some photos and images used in this report were provided by members of the public; these contributions are greatly appreciated. Where appropriate, these people have been acknowledged in the text. Information and text previously compiled for DGGS Information Circular 60 were used extensively.

The booklet's design, layout, and cover are by Joni Robinson (DGGS); Paula Davis (DGGS) edited the final version. Commerce's Division of Economic Development paid printing costs.

Table 5. State corporate income tax rate.

\begin{tabular}{lrlr}
\hline Net Income & $\begin{array}{c}\text { Base } \\
\text { Tax }\end{array}$ & $\begin{array}{c}\text { Plus } \\
\%\end{array}$ & $\begin{array}{c}\text { Of Amount } \\
\text { Over }\end{array}$ \\
\hline$<\$ 10,000$ & $\$--$ & $1 \%$ & $\$$ \\
$10,000-20,000$ & 100 & $2 \%$ & 10,000 \\
$20,000-30,000$ & 300 & $3 \%$ & 20,000 \\
$30,000-40,000$ & 600 & $4 \%$ & 30,000 \\
$40,000-50,000$ & 1,000 & $5 \%$ & 40,000 \\
$50,000-60,000$ & 1,500 & $6 \%$ & 50,000 \\
$60,000-70,000$ & 2,100 & $7 \%$ & 60,000 \\
$70,000-80,000$ & 2,800 & $8 \%$ & 70,000 \\
$80,000-90,000$ & 3,600 & $9 \%$ & 80,000 \\
$>\$ 90,000$ & $\$ 4,500$ & $9.40 \%$ & $\$ 90,000$
\end{tabular}




\section{EXPLORATION}

Mineral exploration expenditures in Alaska during 2009 were at least $\$ 180.0$ million, a sharp drop from the record value of $\$ 347.3$ million set in 2008 . Figure 7 shows the location of the most significant exploration projects in Alaska during the year. Twenty-three projects reported exploration expenditures of $\$ 1$ million or more and 39 additional projects expended $\$ 100,000$ or more. Most exploration funds, approximately 90 percent, were from Canadian sources. Almost 4 percent of funds were from overseas sources. Exploration projects spanned the state.

Decreased exploration expenditures in Alaska during 2009 followed worldwide trends. The worldwide economic downturn limited the amount of venture capital available for mineral exploration. In general, gold exploration projects were funded preferentially to other exploration targets following the rising gold price throughout the year. Advanced exploration projects for all commodities were generally funded at some level in 2009. Some projects postponed major expenditures like drilling as the worldwide financial crisis continued to affect financial markets.

Figure 8 shows a graph of mineral exploration expenditures in Alaska from 1956 to 2009. Exploration expenditures per year are shown with raw (not adjusted for inflation) and adjusted values (inflation adjusted to 2009 dollars). Exploration expenditures over the last several years have exceeded any previous era of mineral exploration in Alaska during the past 50 years. Companies explored for a wide variety of mineral deposits in Alaska during 2009. Table 6 lists exploration expenditures by commodity while figure 9 shows the data graphically.

Exploration was conducted in Alaska for a wide variety of metals and mineralization styles during 2009. Gold, grouped with other precious metals, remained a major exploration commodity, but exploration expenditures for deposits with a mixed group of metals (polymetallic) were also very strong and accounted for 48 percent of total exploration expenditures. Platinumgroup-element (PGE) exploration expenditures in 2009 were slightly above the average PGE expenditures from 2001 through 2008. Figure 10 shows 2009 Alaska exploration expenditures by deposit type. Copper-gold porphyry systems (grouped with polymetallic deposits in table 6) were the major exploration target in 2009, with slightly more than $\$ 74.5$ million in expenditures. In excess of $\$ 64.5$ million was spent on intrusion-related gold deposits and more than $\$ 12$ million was spent on various gold-quartz vein deposits. The sharp decrease in exploration expenditures for base-metal-rich, polymetallic massive-sulfide deposits was notable, with \$15 million spent in 2009, compared to more than $\$ 30$ million spent in 2008 and almost \$59.4 million spent in 2007. About \$4.2 million was spent on PGE-nickel-copper ultramafic-hosted deposits and almost $\$ 9.3$ million was spent on uranium, diamond, tin, coal, placer gold, and other deposit types, including significant expenditures exploring for iron-titanium-rich beach placer deposits.

Analysis of 2009 mineral exploration expenditures indicates that 41 percent of funds were spent exploring for porphyry copper-gold-molybdenum deposits, 36 percent for intrusion-related gold deposits, 8 percent for various types of massive sulfide deposits, 7 percent for gold vein deposits, and the remainder for a wide variety of deposit types. These percentages are not significantly different than the 2008 values.

Exploration occurred across Alaska, as shown in table 7, but more than $\$ 99$ million (55 percent of the exploration funds) were spent in southwestern Alaska and \$35 million were spent in the Eastern Interior region (fig. 11). However, the southwestern region saw a sharp decrease in exploration spending compared to 2008. Exploration expenditures also dropped sharply in the northern region during 2009 compared to 2008; moderate decreases occurred in the southcentral, eastern Interior, and southeastern regions. Exploration expenditures in the western region for 2009 increased 43 percent compared to 2008 expenditures.

Two advanced exploration projects, Pebble and Donlin Creek, accounted for more than 50 percent of the exploration expenditures in 2009. The Pebble copper-gold porphyry project in southwestern Alaska, with resources of 72 billion pounds of copper, 94 million ounces of gold, and 4.8 billion pounds of molybdenum, is a joint-venture project of Northern Dynasty Minerals Ltd. and Anglo American PLC, and was the largest exploration project in 2009. The 35.3-million-ounce Donlin Creek intrusion-hosted gold project in southwestern Alaska is a joint venture of Barrick Gold Corp., NovaGold Resources Inc., and Calista Corp.

Table 8 summarizes the number of new and active (new plus existing) mining claims per year, from 1991 through 2009. The table lists the number of 20 -acre federal mining claims, 160 -acre state prospecting sites, and 40- or 160-acre state mining claims. New mining claims staked during 2009 included 3,935 new state claims (492,560 acres), 40 new state prospecting sites $(6,400$ acres), and 1,057 new federal claims (21,140 acres). State claim staking increased more than 7 percent from 2008 levels, while the number of new federal mining claims decreased to 35 percent of the claims staked in 
I Northern Region

1. Red Dog Mine-Teck Alaska Inc.

2. Lik-Zazu Metals Corp.

3. Ambler Project-NovaGold Resources Inc.

4. Nolan Creek Mine-Silverado Gold Mines Ltd.

5. Western Arctic Coal-BHP Billiton Ltd.

6. Baird Mountain Project-TintinaGold Resources Inc.

\section{Western Region}

7. Rock Creek, Big Hurrah-NovaGold Resources Inc.

8. Colorado Creek-TintinaGold Resources Corp.

9. Kugruk-TintinaGold Resources Corp.

10. Nixon Fork Mine-Fire River Gold Corp.

11. Silver Chalice-Next Gen Metals Inc.

12. Omalik - TintinaGold Resources Corp.

13. Albion, Bering Straits-Millrock Resources Inc./Kinross Gold Corp.

14. RWN-Royal Pretoria Gold Inc.

15. Mystery Mountains-Newmont Exploration Ltd.

\section{Eastern Interior Region}

16. Livengood - International Tower Hill Mines Ltd

17. Fairbanks District

a. Fort Knox \& District-Kinross Gold Corp.

b. Golden Summit-Freegold Ventures Ltd.

c. Coffee Dome - International Tower Hill Mines Ltd.

d. Gil—Kinross Gold Corp./Teryl Resources Corp.

18. Pogo-Goodpaster mining district

a. Pogo-Sumitomo Metal Mining Pogo LLC

b. Maple Leaf, California North, ER-Ogo-FireRubicon Minerals Corp.

c. Rob-Freegold Ventures Ltd.

d. Mon-Sumitomo Metal Mining/Stone Boy Inc./ Pathfinder Mineral Services

19. Fortymile-Full Metal Minerals Ltd.

20. Gold Hill-Max Resource Corp.

21. Liberty Bell-New Gold Inc.

22. Caribou Dome-Caribou Copper Resources Ltd.

23. Tetlin-Contango ORE Co.

24. Tushtena-Triton Gold Ltd./Tushtena Resources Inc.

\section{Southcentral Region}

25. Chisna-International Tower Hill Mines Ltd.

26. Whistler-Kiska Metals Corp.

27. MAN-Pure Nickel Inc./Itochu Corp.

28. Golden Zone-Fire River Gold Corp.

29. Lucky Shot-Full Metal Minerals Ltd.

30. Yakutat-Geohedral LLC

31. Estelle-Millrock Resources Inc.

Figure 7. Selected exploration projects in Alaska, 2009.

\section{Southwestern Region}

32. Donlin Creek-Donlin Creek JV

33. Pebble-Northern Dynasty Minerals Ltd./Anglo American PLC

34. Terra-International Tower Hill Mines Ltd.

35. Tintina Gold - TintinaGold Resources Inc.

36. Russian Mountains-Full Metal Minerals Ltd.

37. Nyac - Calista Corp.

38. Vinasale-Freegold Ventures Ltd.

39. Goodnews Bay - XS Platinum Ltd.

40. a. Pebble South-Freeport-McMoRan Exploration Corp./Full Metal Minerals Ltd.

b. Big Chunk-Liberty Star Uranium \& Metals Co.

41. Tatalina River-Newmont Exploration Ltd.

42. Golden Lynx-TintinaGold Resources Inc.

\section{Alaska Peninsula Region}

43. Bee Creek/Kawisgag_Full Metal Minerals Ltd.

\section{Southeastern Region}

44. Kensington, Jualin-Coeur Alaska Inc.

45. Greens Creek Mine-Hecla Mining Co.

46. Palmer - Constantine Metal Resources Ltd.

47. Niblack-CBR Gold Corp./Heatherdale Resources Ltd.

48. Bokan Mountain-Ucore Uranium Inc./Rare Earth One

49. Mount Andrew-Mosam Capital Corp./Full Metal Minerals Ltd.

50. Woewodski Island-Bravo Venture Group Inc./Olympic Resources Group LLC

51. Duke Island - Quaterra Resources Inc./Copper Ridge Explorations Inc. 


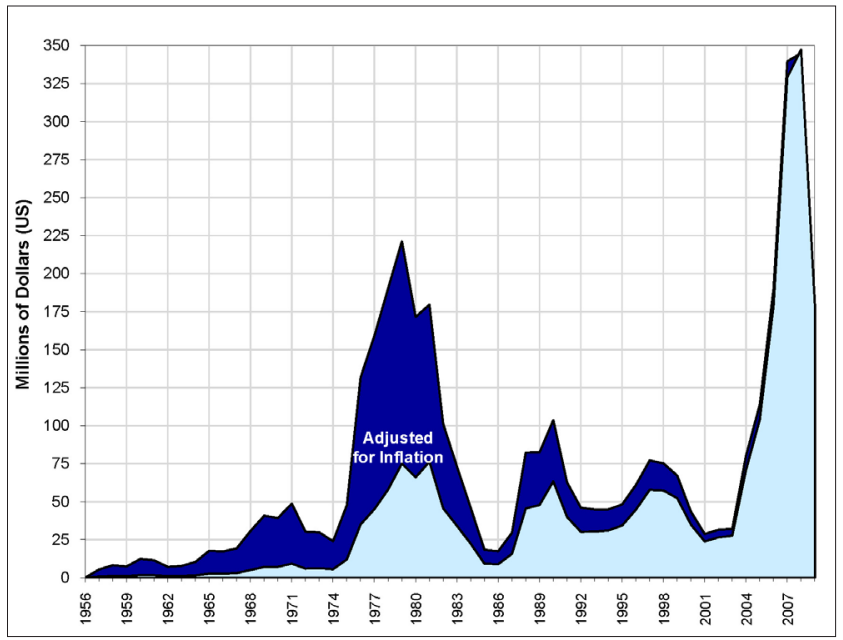

Figure 8. Alaska mineral exploration expenditures, 1956-2009. Inflation adjusted to 2009 dollars.

Table 6. Reported exploration expenditures in Alaska by commodity, 1981-2009.

\begin{tabular}{|c|c|c|c|c|c|c|c|c|}
\hline & $\begin{array}{c}\text { Base } \\
\text { metals }\end{array}$ & Polymetallic $^{\mathbf{a}}$ & & $\begin{array}{l}\text { Precious } \\
\text { metals }^{\text {b }}\end{array}$ & $\begin{array}{c}\text { Industrial } \\
\text { minerals }\end{array}$ & $\begin{array}{c}\text { Coal } \\
\text { and peat }\end{array}$ & Other $^{\mathrm{c}}$ & Total \\
\hline 1981 & $\$ 28,262,200$ & N/A & $\$$ & $35,273,200$ & $\$ 10,300,000$ & $\$ 2,341,000$ & 127,000 & $\$ 76,303,400$ \\
\hline 1982 & $31,757,900$ & N/A & & $10,944,100$ & - & $2,900,000$ & 15,300 & $45,617,300$ \\
\hline 1983 & $9,758,760$ & $\mathrm{~N} / \mathrm{A}$ & & $20,897,555$ & $2,068,300$ & $1,338,454$ & 70,000 & $34,133,069$ \\
\hline 1984 & $4,720,596$ & N/A & & $14,948,554$ & 270,000 & $2,065,000$ & 279,500 & $22,283,650$ \\
\hline 1985 & $2,397,600$ & N/A & & $6,482,400$ & - & 270,000 & - & $9,150,000$ \\
\hline 1986 & $1,847,660$ & N/A & & $6,107,084$ & 170,000 & 790,000 & -- & $8,914,744$ \\
\hline 1987 & $2,523,350$ & N/A & & $11,743,711$ & 286,000 & $1,150,000$ & 31,000 & $15,734,061$ \\
\hline 1988 & $1,208,000$ & N/A & & $41,370,600$ & 160,200 & $2,730,000$ & - & $45,468,800$ \\
\hline 1989 & $3,503,000$ & $\mathrm{~N} / \mathrm{A}$ & & $43,205,300$ & 125,000 & 924,296 & 5,000 & $47,762,596$ \\
\hline 1990 & $5,282,200$ & $\mathrm{~N} / \mathrm{A}$ & & $57,185,394$ & 370,000 & 321,000 & 97,000 & $63,255,594$ \\
\hline 1991 & $4,789,500$ & N/A & & $34,422,039$ & 92,000 & 603,000 & 2,000 & $39,908,539$ \\
\hline 1992 & $1,116,000$ & $3,560,000$ & & $25,083,000$ & 25,000 & 425,000 & - - & $30,209,000$ \\
\hline 1993 & 910,000 & $5,676,743$ & & $23,382,246$ & 163,500 & -- & 125,000 & $30,257,489$ \\
\hline 1994 & 600,000 & $8,099,054$ & & $18,815,560$ & 225,000 & $2,554,000$ & 810,000 & $31,103,614$ \\
\hline 1995 & $2,770,000$ & $10,550,000$ & & $20,883,100$ & 100,000 & -- & 3,000 & $34,306,100$ \\
\hline 1996 & $1,100,000$ & $11,983,364$ & & $31,238,600$ & 400,000 & -- & -- & $44,721,964$ \\
\hline 1997 & $1,700,000$ & $22,347,000$ & & $32,960,500$ & 80,000 & 720,000 & -- & $57,807,500$ \\
\hline 1998 & $1,000,000$ & $13,727,000$ & & $42,441,000$ & 12,000 & 87,000 & -- & $57,267,000$ \\
\hline 1999 & $3,869,000$ & $3,168,000$ & & $44,891,000$ & 1,000 & -- & 410,000 & $52,339,000$ \\
\hline 2000 & $8,545,000$ & $3,933,000$ & & $21,579,000$ & 58,500 & -- & 736,100 & $34,851,600$ \\
\hline 2001 & $4,810,000$ & $1,977,000$ & & $15,820,000$ & 50,000 & 10,000 & $1,106,000$ & $23,773,000$ \\
\hline 2002 & $1,700,000$ & $5,162,000$ & & $17,342,000$ & 185,000 & - - & $2,113,000$ & $26,502,000$ \\
\hline 2003 & 262,000 & $7,081,000$ & & $19,726,000$ & -- & $\mathrm{W}$ & 533,000 & $27,602,000$ \\
\hline 2004 & $3,100,000$ & $40,237,000$ & & $26,954,000$ & 213,000 & 50,000 & 258,000 & $70,812,000$ \\
\hline 2005 & $1,764,000$ & $54,271,000$ & & $46,255,000$ & 142,000 & - & $1,463,000$ & $103,895,000$ \\
\hline 2006 & $5,069,000$ & $81,073,000$ & & $89,793,000$ & 20,000 & $2,394,000$ & 580,000 & $178,929,000$ \\
\hline 2007 & $38,888,000$ & $123,487,500$ & & $155,601,400$ & 42,500 & $7,675,000$ & $3,447,000$ & $329,141,400$ \\
\hline 2008 & $30,116,000$ & $163,030,000$ & & $134,885,000$ & - - & W & $19,238,000$ & $347,269,000$ \\
\hline 2009 & $3,862,715$ & $85,871,529$ & & $84,020,531$ & 17,850 & $\mathrm{~W}$ & $6,193,518$ & $179,966,143$ \\
\hline TOTAL & $207,232,481$ & $\$ 645,234,190$ & & I,134,250,874 & $\$ 15,576,850$ & $\$ 29,347,750$ & $\$ 37,642,418$ & $\$ 2,069,284,563$ \\
\hline
\end{tabular}

a Polymetallic deposits considered a separate category for the first time in 1992.

${ }^{\mathrm{b}}$ Approximately $\$ 4.1 \mathrm{M}$ spent on platinum-group-element exploration during 2009 (\$3.2M in 2008, \$3.0M in 2007, \$1.4M in 2006, \$4.4M in $2005, \$ 3.4 \mathrm{M}$ in $2004, \$ 2.4 \mathrm{M}$ in $2003, \$ 650,000$ in 2002 , $\$ 2 \mathrm{M}$ in 2001).

'Includes uranium, tin, diamonds, magnetite sands, and tantalum.

$\mathrm{N} / \mathrm{A}=$ Not available

- - Not reported.

$\mathrm{W}=$ Withheld; data included in "Other" column. 


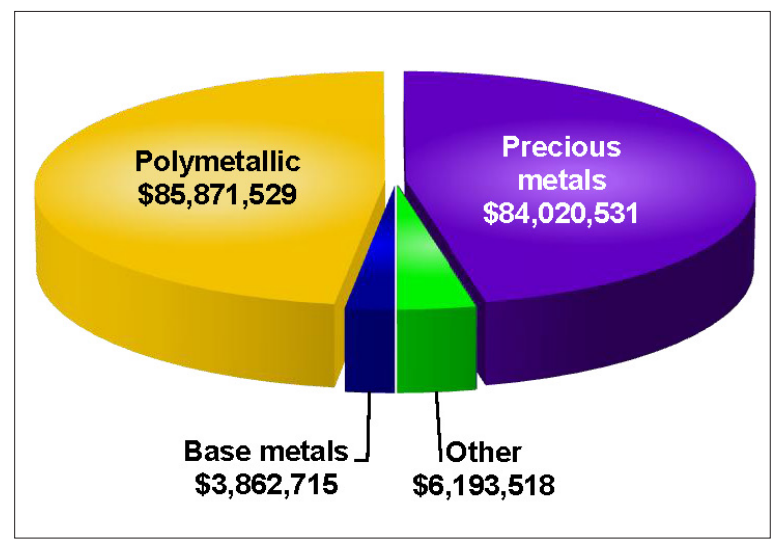

Figure 9. Exploration expenditures in Alaska in 2009 by commodity.

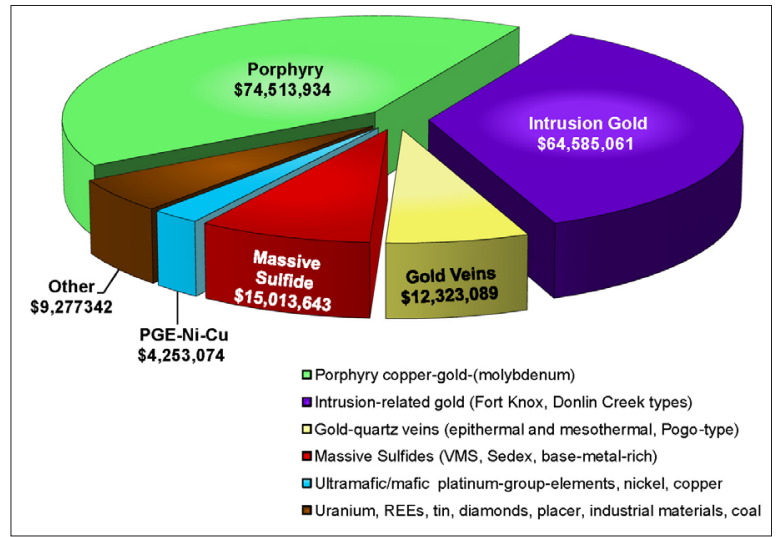

Figure 10. Alaska exploration expenditures in 2009 by deposit type.
2008. The number of active federal claims also decreased about 10 percent from 2008 to 2009. The amount of land in Alaska under claim increased approximately 13 percent from 2008 to 2009, with approximately 3.86 million acres of land covered by claims and prospecting sites in 2009. Alaska had 10,431 active federal and 40,721 active state mining claims in 2009. Prospecting sites and mining claims were staked across Alaska, with detailed information listed in Appendices A and B.

\section{NORTHERN REGION}

Zazu Metals Corp. reported completion of a Canadian National Instrument (NI) 43-101 resource estimate for the Lik zinc-lead-silver massive sulfide project by contractor Scott Wilson Roscoe Postle Associates Inc. The resource estimate is based on 204 diamond drill holes in the Lik South deposit and Lik North, its offset extension. The resource estimate includes more than 3.3 billion pounds of zinc, more than 1 billion pounds of lead, and more than 31 million ounces of silver in the indicated category for the Lik South deposit. It also tallied nearly 1.3 billion pounds of zinc, almost 500 million pounds of lead, and nearly 10 million ounces of silver in the inferred resource category for the Lik North and Lik South deposits. The Lik South deposit is amenable to open pit mining methods, according to Zazu, and the Lik North deposit could be mined underground with access from the bottom of the Lik South pit. The Alaska Industrial Development and Export Authority (AIDEA) approved a cost reimbursement agreement with Zazu and initiated due diligence on the proposed expansion of the De Long Mountain Transportation System to the Lik deposit. AIDEA may finance building the spur road to the Lik deposit and building additional storage and handling facilities at the Chukchi Sea port.

Table 7. Reported exploration expenditures and employment in Alaska, 2009.

\begin{tabular}{|c|c|c|c|c|c|c|c|c|}
\hline & Northern & Western & $\begin{array}{l}\text { Eastern } \\
\text { Interior }\end{array}$ & $\begin{array}{l}\text { South- } \\
\text { central }\end{array}$ & $\begin{array}{c}\text { South- } \\
\text { western }\end{array}$ & $\begin{array}{l}\text { South- } \\
\text { eastern }\end{array}$ & $\begin{array}{c}\text { Alaska } \\
\text { Peninsula }\end{array}$ & Total \\
\hline \multicolumn{9}{|c|}{ Exploration expenditures } \\
\hline Placer & $\$ 122,000$ & $\$ 2,098,660$ & $\$ \quad 446,301$ & $\$ 1,270,102$ & 327,925 & 10,600 & $\$ 5,000$ & $\$ \quad 4,280,588$ \\
\hline Lode & $7,071,690$ & $9,344,679$ & $34,595,171$ & $11,463,742$ & $99,110,596$ & $13,925,157$ & 174,521 & $175,685,556$ \\
\hline TOTAL & $\$ 7,193,690$ & $\$ 11,443,339$ & $\$ 35,041,472$ & $\$ 12,733,844$ & $\$ 99,438,521$ & $\$ 13,935,757$ & $\$ 179,521$ & $\$ 179,966,144$ \\
\hline \multicolumn{9}{|c|}{ Exploration employment } \\
\hline $\begin{array}{c}\text { Employmen } \\
\text { workdays }\end{array}$ & 3,238 & 3,223 & 19,691 & 8,159 & 66,467 & 8,776 & 58 & 109,612 \\
\hline Workyear & 12 & 12 & 76 & 31 & 256 & 34 & 1 & 422 \\
\hline \multicolumn{8}{|c|}{ Companies } & 327 \\
\hline
\end{tabular}

${ }^{a}$ Based on 260-day workyear.

${ }^{\mathrm{b} S}$ Some companies were active in several areas. 
Teck Alaska Inc. continued its exploration drilling program for polymetallic sedimentary-hosted massive sulfide deposits in the area surrounding Red Dog Mine. Long-term dewatering of five nearby shallow shale-gas exploration wells also continued. Gas flow tests will be conducted when the formation has been sufficiently dewatered. The flow tests will form the basis for decisions related to the economic feasibility of converting from diesel-fired power to natural gas obtained from the shale formations.

NovaGold Resources Inc. agreed to purchase the Ambler property, which hosts the high-grade copperzinc-gold-silver Arctic volcanogenic massive sulfide

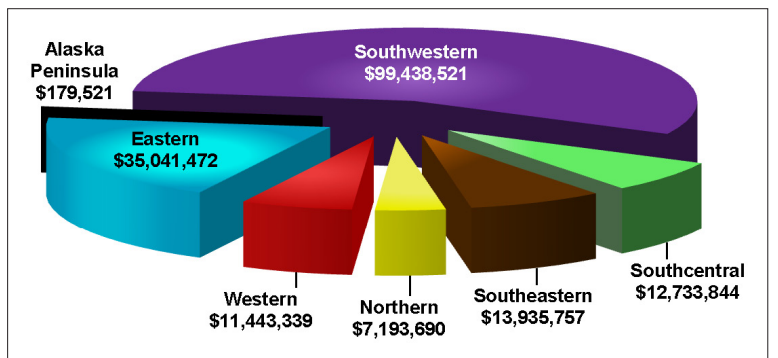

Figure 11. 2009 Alaska exploration expenditures by region. deposit, from Kennecott Exploration Co. for \$29 million. Work on the property in 2009 consisted primarily of community engagement.

Silverado Gold Mines Ltd. completed an NI 43-101 compliant report on the Workman's bench section of the Nolan gold-antimony lode property. The report states a probable reserve of 42,412 tons grading 28 percent antimony and 0.408 ounces of gold per ton as determined from drilling conducted through 2008. Silverado drilled 20 diamond-core drill holes totaling 4,992 feet under Workman's and Pringle benches in the Solomon Shear Zone. The drill program focused on increasing the size of the antimony-gold A Zone beyond the 2008 resource and reserve blocks. Immediately adjacent to the probable reserve is an indicated resource of 12,039 tons grading 20.02 percent antimony and 0.236 ounces of gold per ton, which was added as a result of the 2009 drilling. Drilling also tested a broad network of lower-grade gold-bearing quartz veins along Pringle Bench.

Goldrich Mining Co. completed a successful placer gold test mining operation on Little Squaw Creek in the Chandalar region. Some exploration was conducted on other placer gold-bearing creeks on the property. Minimal lode exploration was conducted on the Little Squaw property.

Table 8. Summary of claim activity by acres, 1991-2009.

\begin{tabular}{|c|c|c|c|c|c|c|c|c|}
\hline \multirow[b]{2}{*}{ Year } & \multicolumn{4}{|c|}{ State Claims } & \multicolumn{2}{|c|}{ State Prospecting Sites } & \multicolumn{2}{|c|}{ Federal Claims } \\
\hline & $\begin{array}{c}\text { New } \\
\text { (Active) } \\
40 \text { acre }^{\mathrm{a}}\end{array}$ & $\begin{array}{c}\text { New } \\
\text { (Active) } \\
160 \text { acre }\end{array}$ & $\begin{array}{c}\text { Total } \\
\text { (Active) } \\
40 \text { acre }^{a}\end{array}$ & $\begin{array}{c}\text { Total } \\
\text { (Active) } \\
160 \text { acre }\end{array}$ & New & Total & New & Total \\
\hline 1991 & 3,277 & 0 & 37,862 & 0 & 747 & 1,723 & 1,299 & 23,222 \\
\hline 1992 & 2,640 & 0 & 36,250 & 0 & 454 & 1,472 & 695 & 20,254 \\
\hline 1993 & 2,120 & 0 & 34,340 & 0 & 1,412 & 2,259 & 601 & 9,298 \\
\hline 1994 & 4,057 & 0 & 34,400 & 0 & 802 & 2,378 & 341 & 8,495 \\
\hline 1995 & 4,512 & 0 & 30,464 & 0 & 1,030 & 2,725 & 376 & 7,766 \\
\hline 1996 & 9,489 & 0 & 36,602 & 0 & 2,082 & 3,687 & 681 & 9,346 \\
\hline 1997 & 8,678 & 0 & 42,836 & 0 & 2,480 & 5,305 & 1,872 & 11,320 \\
\hline 1998 & 9,786 & 0 & 49,816 & 0 & 3,194 & 7,148 & 427 & 11,033 \\
\hline 1999 & 11,978 & 0 & 56,107 & 0 & 1,755 & 7,600 & 308 & 10,176 \\
\hline 2000 & 4,560 & 614 & 54,393 & 614 & 1,143 & 5,675 & 523 & 7,805 \\
\hline 2001 & 858 & 907 & 49,627 & 1,503 & 27 & 3,091 & 464 & 8,248 \\
\hline 2002 & 745 & 826 & 44,056 & 2,179 & 61 & 2,138 & 261 & 8,100 \\
\hline 2003 & 856 & 2,603 & 38,076 & 4,387 & 101 & 1,857 & 676 & 8,424 \\
\hline 2004 & 1,070 & 3,533 & 34,380 & 7,719 & 59 & 1,484 & 66 & 8,313 \\
\hline 2005 & 806 & 4,502 & 34,066 & 11,551 & 128 & 1,612 & 411 & 7,826 \\
\hline 2006 & 1,111 & 5,747 & 33,864 & 16,249 & 103 & 1,646 & 457 & 8,068 \\
\hline 2007 & 576 & 6,031 & 31,305 & 20,208 & 57 & 1,625 & 933 & 8,872 \\
\hline 2008 & 1,333 & 2,565 & 23,033 & 13,519 & 24 & 651 & 3,001 & 11,732 \\
\hline 2009 & 1,142 & 2,793 & 24,340 & 16,381 & 40 & 335 & 1,057 & 10,431 \\
\hline
\end{tabular}

Updated information provided by James McJimsey (Land Records Information Section, DNR), and Melody Smyth and Julie Capps (U.S. BLM). Table has been reorganized to conform with computer records available after 1990.

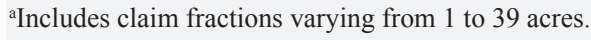


TintinaGold Resources Inc., formerly Mantra Mining Inc., had a small exploration program at the Baird property. Reconnaissance rock sampling focused on the Capital Hill area at the southeast end of a 6-mile-long zinc-lead-barium geochemical anomaly. Samples of scattered gossan float trains and lenses in carbonate contain as much as 1 percent zinc, 0.5 percent lead, and 500 parts per million copper; and samples of silica-barite veins in carbonate assayed as much as 5.3 percent zinc.

BHP Billiton Ltd. completed a third year of exploration at the Western Arctic Coal Project under a 5-year exploration agreement with Arctic Slope Regional Corp. Work included camp and drill site remediation.

Andover Ventures Inc. continued to evaluate results from previous work on the Sun volcanogenic massive sulfide property. Andover planned to complete a NI 43-101 compliant mineral resource estimate for the property in 2010 .

At least 23 individuals and companies reported placer gold exploration activities at various properties across the region. Much of the exploration was conducted in the Wiseman area and consisted of prospecting by panning or small-scale sluicing.

\section{WESTERN REGION}

Fire River Gold Corp. finalized acquisition of a 100 percent interest in the Nixon Fork gold-copper mine from Pacific North West Capital Corp. with a stock, cash, and work reimbursement deal. Fire River began a $\$ 1.25$ million evaluation of the project to confirm previous geologic work through re-logging all existing core at the site in conjunction with underground mapping of current workings, re-assaying selective drill intercepts, checking drill hole surveys, and confirming or building a geological model. Work was also planned to confirm the gold grade of the tailings pond, and conduct metallurgical testing. The evaluation program continued into 2010 .

Next Gen Metals Inc. entered into an agreement with Anglo Alaska Gold Corp., a privately owned Alaska corporation, to acquire a 100 percent interest in the Silver Chalice epithermal gold-silver project near Kaltag. Preliminary geochemical sampling was conducted in late 2009.

Mantra Mining Inc. acquired five of NovaGold Resources Inc.'s Alaska properties in exchange for 3.125 million shares of Mantra common stock, or about a 7 percent interest in the company. The deal gives Mantra Alaska state mining claims at the Colorado Creek and TintinaGold exploration properties, and the Kugruk, Baird, and Omalik polymetallic base metal properties.

TintinaGold Resources Inc., formerly Mantra Mining Inc., drilled 12 holes totaling 8,356 feet at the Colorado Creek gold property. The best results in this latest drilling encountered 323 feet grading 0.017 ounces of gold per ton (hole DDH 12); 79 feet grading 0.034 ounces of gold per ton and 7.5 feet grading 0.222 ounces of gold per ton within 364 feet grading 0.019 ounces of gold per ton (hole DDH 14); and 147 feet grading 0.029 ounces of gold per ton within 421 feet grading 0.017 ounces of gold per ton (hole DDH 15). Gold mineralization occurs in quartz-calcite-arsenopyrite-pyrite veins with sericite, carbonate, and clay alteration in rhyodacite and andesite. Reconnaissance soil sampling extended the gold-in-soil anomaly to a length of 5 miles with a width of up to 1.5 miles, and portions of the anomaly remain open.

TintinaGold Resources conducted orientationinduced polarization (IP) resistivity and gravity surveys over the three highest priority airborne geophysical anomalies on its Kugruk property. These anomalies include a 1.8-mile-long, very-high-magnetic zone at Billiken; a 1.8-mile-long, low-resistivity zone on the south flank of the Kugruk pluton; and a 3-mile-long, low-resistivity zone with coincident copper-in-soil anomaly in the Knowles Creek area in the south part of the claim block.

TintinaGold also worked on its Omalik property, with soil sampling across mineralized trends and rock sampling across the claim block.

Millrock Resources Inc. optioned the Albion property in the Council mining district on the Seward Peninsula. The 51 state mining claims are immediately adjacent to Millrock's land optioned from the Bering Straits Native Corp. Millrock entered into an exploration agreement with Kinross Gold Corp. for these properties. Millrock also announced a joint-venture agreement with Valdez Gold Inc. that gave Valdez Gold the rights to up to 75 percent interest in the Bluff project east of Nome, but the final agreement was not signed by year's end.

Newmont Exploration Ltd. conducted geologic mapping, geochemical sampling including 950 soil samples, and an IP geophysical program in the Mystery Mountains. Results of these studies were not announced.

Hinterland Metals Inc. staked claims on the Windy Fork property, covering two documented rare earth element showings, the Windy Fork placer, and the Eudialyte lode prospects. Past work on the placer deposits indicate that the gravels in the Windy Fork of the Kuskokwim River contain abundant chevkinite, eudialyte, ilmenite, monazite, and zircon and minor to trace allanite, cassiterite, and thorite.

Royal Pretoria Gold Inc. drilled 1,930 feet of core at the RWN property near Deering. At least 176 samples were collected for geochemical analysis, but no results were announced.

At least 22 individuals or companies reported limited placer gold exploration across the region. Most of the operations were on the Seward Peninsula. There was also limited lode exploration for gold in the Kigluaik 
Mountains; tin at the Win, Won, and Kougarok Mountain prospects; and polymetallic mineralization at the Wheeler, Foster, and Granite Creek prospects.

\section{EASTERN INTERIOR REGION}

International Tower Hill Mines Ltd. continued an aggressive exploration drill program on the Livengood project, with 207 holes totaling 211,000 feet completed in 2009. The surface gold geochemical anomaly at Livengood covers an area 3.7 miles long by 1 mile wide, of which approximately half has been explored by drilling through the end of 2009. Drilling continued to expand the eastern half of the Money Knob gold deposit, which includes the Sunshine, Northeast, Core (Money Knob), and Southwest zones. In addition, significant new mineralization was discovered in the Northwest Zone (drillholes MK-RC-0279 with 49 feet averaging 0.108 ounces of gold per ton and MK-RC-0281 with 75.5 feet averaging 0.026 ounces of gold per ton). In the new Sunshine and Northeast zones, mineralization begins at surface and extends to over 558-foot depth. Environmental baseline sampling program, wetlands mapping, and other related long-term mine permitting projects were also ongoing. The latest resource estimate (October 2009), at a 0.015 ounce of gold per ton cutoff, has an indicated resource of 327.1 million tons at an average grade of 0.025 ounces of gold per ton $(8.09$ million ounces) and an inferred resource of 70.8 million tons at an average grade of 0.025 ounces of gold per ton (4.4 million ounces). These resources make the Money Knob deposit one of the largest new gold discoveries in North America. The Core and Sunshine zones account for most of the higher-grade resource. Preliminary metallurgical and economic analysis study results are quite favorable, including a heap leach analysis for oxide ore yielding a life-of-project annual gold production of 459,000 recovered ounces of gold for 12.6 years, at a 0.78:1 strip ratio. Using a gold price of $\$ 850$ per ounce, an oxide-only mine would produce a 14.6 percent internal rate of return.

Fairbanks Gold Mining Inc., a subsidiary of Kinross Gold Corp., continued ore-body delineation with a 107,066-foot, 135-hole drilling program at Fort Knox Mine. Reverse-circulation drilling totaled 61,860 feet in 82 holes and core drilling totaled 45,206 feet in 53 holes.

Fairbanks Gold also added to an existing soil sample grid, drilled 33 reverse-circulation and six core holes totaling 15,295 feet and completed a 2.2-line-mile ground magnetometer survey concentrating on the Sourdough Ridge portion of the Gil project via a new 3,000 foot access road. Drill results included 105 feet grading 0.14 ounces of gold per ton in hole GVR-09-540 and 75 feet grading 0.09 ounces of gold per ton in hole GVR-09-534. The current drilling along Sourdough Ridge has drill indicated a mineralized zone at least 1,500 feet long, which remains open to the east. The Sourdough Ridge zone is adjacent to and east of the Main Gil zone, with a 2,500-foot-long mineralized zone. Near year's end, Fairbanks Gold offered to acquire Teryl Resources Corp.'s 20 percent interest in the Gil property. The offer was under review.

Sumitomo Metal Mining Pogo LLC continued exploration drilling at the Pogo Mine property. The 2009 exploration program at Pogo Mine focused entirely on drill targets in the immediate mine area. Surface drilling completed 44 core holes totaling 52,655 feet (NQ size core) and was conducted from June 18 through October 25. The surface drilling was helicopter-supported through September 11, and thereafter road-based. Surface drilling was contracted to Connors Drilling Co. using two CS-1000 fly-rigs. Connors Drilling also did the underground exploration drilling, completing 35 core holes totaling 17,745 feet (NQ size core). This drilling was undertaken intermittently in two phases from January 13 to April 10 and June 15 to October 5, 2009.

In late 2009, Grayd Resource Corp. staked 238 additional claims to cover prospective geology around the original 23 claims it owns in the Delta mining district.

Caribou Copper Resources Ltd. acquired all of the issued and outstanding shares of 1618254 Ontario Ltd. and 1618254 Ontario Ltd. completed two drillholes totaling 2,038 feet on the Caribou Dome copper property. Four distinct intervals of chalcopyrite-pyrite mineralization were encountered in one hole with visible pyrite over much of the hole below 339 feet.

Contango Oil \& Gas Co. agreed to invest up to $\$ 3.0$ million to conduct mineral exploration on approximately 580,000 acres of Alaska Native and State of Alaska lands near Tetlin. Contango purchased a 50 percent interest in the project from a private company. Contango collected a total of 1,076 rock, soil, pan concentrate, and stream silt samples. Of this total, 567 rock and soil samples were taken over a 40-acre area of exploration interest, with 348 samples showing measurable amounts of gold and 30 samples with gold values of 0.015 ounces of gold per ton or higher.

Millrock Resources Inc. optioned the Uncle Sam property from Kiska Metals Corp. The agreement grants Millrock the option to purchase a 100 percent interest in the Uncle Sam property by making cash payments, meeting exploration work commitments, and by issuing Millrock shares to Kiska.

Triton Gold Ltd. and joint-venture partner Tushtena Resources Inc. completed a short geological and geochemical mapping program and staked an additional 24 mining claims on the Tushtena property. The program was aimed at gathering detailed structural data on key areas of the Tushtena property, specifically around the 
Discovery, RS, and Dave's zones. A total of 214 rock chip samples were collected but results were not announced.

International Tower Hill Mines Ltd. completed a five-core-hole, 4,449-foot drilling campaign at the Coffee Dome project, testing the UAF and Zesiger areas. Results from the UAF area returned multiple thick zones of low-grade gold associated with arsenic in quartzite, highlighted by 56 feet grading 0.009 ounces of gold per ton and 72 feet grading 0.006 ounces of gold per ton in hole CD-09-03. The drill hole in the Zesiger target encountered the projected fault zone hosting mineralization in surface trenching, but drill results did not have significant gold mineralization.

Ashburton Ventures Inc. drill tested the Two Bit granitic pluton and surrounding metasedimentary rocks at the Bullion Hills property in the Circle mining district. Eight holes totaling 1,442 feet were drilled to a maximum depth of 300 feet. The best drill interval averaged 0.064 ounces of gold per ton over 4 feet.

Select Resources Corp., the minerals subsidiary of Tri-Valley Corp., increased its land position at its Shorty Creek gold property in the Livengood area from about 17 square miles to about 39 square miles by staking state mining claims.

Fire River Gold Corp. conducted a geochemical sampling program on the Draken property. Six 160acre claims cover the discovery outcrop on the Taylor Highway and an adjacent area to the east. A NI 43-101 technical report on this gold property was completed by Spectrum Resources Inc. Fire River Gold also acquired the Kansas Creek gold property in the Bonnifield Mining District from Pacific North West Capital. The property covers about 4,150 acres over potential lode gold mineralization. Rock sampling was conducted on both properties but results were not released.

Usibelli Coal Mine Inc. performed a property-wide reassessment of all available geologic data to obtain a current estimate of coal reserves on its leases in the Nenana Coal Field near Healy, Alaska. This assessment includes data from hundreds of exploration drill holes, outcrop mapping, production data, and other pertinent geologic information. This effort identified a surface mineable reserve base of approximately 700 million tons, of which, 450 million can be classified as proven and 250 million as probable. Some of the reserve areas are open ended and future exploration work and analysis is expected to increase the total figure to near one billion tons. All of the reserves at Usibelli's Healy operations are subbituminous $\mathrm{C}$ rank coal. Typical as-mined analysis is 7,650 Btu/lb, 28 percent moisture, 9 percent ash and 0.2 percent sulfur. In addition to very low sulfur content, Healy coal is also low in mercury and other trace elements of concern, making it one of the cleanest burning coals in the world.
Full Metal Minerals conducted geologic mapping, soil sampling, and property-wide reconnaissance exploration at the LWM polymetallic carbonate replacement prospect near Chicken. Full Metal also conducted mapping and soil and rock sampling on the Tanacross project.

Sumitomo Metal Mining and Stone Boy Inc. contracted Pathfinder Mineral Services to conduct exploration on the Monte Cristo Creek portion of the Stone Boy project. Work included core drilling, but no results were announced.

Alix Resources Corp. completed a soil sampling program on the Money-Rock gold properties near Pogo Mine. No results were announced.

New Gold Inc. continued working on the Liberty Bell property north of Healy including geologic mapping, geochemical sampling, and a core drilling program. No results were announced.

Millrock Resources conducted exploration on three mining claim blocks in the Fortymile mining district. Millrock is targeting disseminated and vein-style intrusion-related lode gold deposits. Millrock conducted mapping and rock and soil geochemical sampling on the Chicken and Canyon creeks properties. Work on the Napoleon property included stream-sediment sampling.

Miranda Gold Corp. leased 171 Alaska state mining claims from Range Minerals Inc. at the Ester Dome project in the Fairbanks mining district. The geology and mineralization on the Ester Dome project is prospective for high-grade vein deposits and shear-hosted gold deposits as well as large tonnage bulk minable gold deposits.

Goldstone Resources LLC trenched and sampled on its Amanita property near Fairbanks.

The Alaska Division of Geological \& Geophysical Surveys conducted geologic mapping along the Alaska Highway from Tetlin Junction to the Yukon-Alaska border and contracted helicopter-borne geophysical surveys for the Melozitna-Tanana area of central Alaska.

Minor placer gold exploration activities, including prospecting, trenching, drilling, and geophysical surveys, were reported by 126 individuals and companies, and work was performed in most mining districts across the region. Lode exploration in the region was also conducted to partially fulfill annual labor requirements to maintain mining claims in good standing.

\section{SOUTHCENTRAL REGION}

Full Metal Minerals Ltd. completed a 26-hole, 7,874-foot core drilling program at the Lucky Shot property. No results were announced. Environmental baseline and engineering studies were also completed. On November 9, 2009, Full Metal announced an option agreement whereby Harmony Gold Corp. can earn a 60 percent interest in the Lucky Shot property by paying $\$ 2$ million cash, issuing 4 million shares, and incurring 
\$8 million in exploration expenditures, upon acceptance of the Toronto Stock Exchange (TSX) Venture Exchange.

Rimfire Minerals Corp. and Geoinformatics Exploration Inc. merged in 2009 to form Kiska Metals Corp. Kiska conducted wide-spaced surface reconnaissance work at the Whistler project. Prospecting and mapping outlined several new areas of gold mineralization, including the Old Man Breccia target, where a continuous 33-foot channel sample returned 0.208 ounces of gold per ton. A total of five drillholes were also completed in 2009. Two holes at the Island Mountain prospect encountered copper and gold mineralization in actinolite-magnetite-altered hydrothermal breccia with pyrrhotite $>$ pyrite $>$ chalcopyrite. Drillhole IM09-001 intersected 1,256 feet of mineralization averaging 0.020 ounces of gold per ton, including an upper 492-foot interval averaging 0.021 ounces of gold per ton, 0.069 ounces of silver per ton, and 0.16 percent copper and a lower 350.7-foot interval at the bottom of the hole averaging 0.036 ounces of gold per ton, 0.020 ounces of silver per ton, and 0.05 percent copper. The three remaining holes were at the Lightning, Digger, and Raintree targets. Drill hole WH09-020 on the Raintree target, ended in mineralization and the total hole, to a depth of 1,547 feet, averaged 0.011 ounces of gold per ton, 0.14 ounces of silver per ton, 0.16 percent copper, 0.14 percent lead, and 0.35 percent zinc. Kiska also conducted a large 3D and 2D IP survey of up to 211 line miles on the Whistler property.

In collaboration with its project partner, Itochu Corp., Pure Nickel Inc. completed 13,779 feet of drilling on the Man nickel-platinum-group-element exploration project. Seven drill holes were completed by Cyr Drilling, with three holes in the Alpha Complex and four holes in the Beta Complex; three holes were abandoned early. Targets were generated from preliminary analysis of an 8,766-line-foot airborne time-domain electromagnetic (ZTEM; Z Axis Tipper Electromagnetic System) survey covering the Alpha and Beta complexes. The survey was conducted by Geotech Ltd. A thicker-thanexpected ultramafic sequence was intersected in hole PNI-09-25, which was drilled to 3,497 feet. Hole PNI09-24 intersected 674 feet grading 0.189 percent nickel. Extensive geophysical work was conducted concurrent with the drilling program. In particular, a new groundtime-domain EM system (full waveform, streaming, multi-sensor fluxgate array), was deployed extensively through the latter half of the exploration season.

Millrock Resources Inc. prospected and sampled on the Estelle property, resulting in the discovery of porphyry-style gold mineralization in bedrock at both the Shoeshine and Oxide Ridge occurrences. Geochemical results from rock chip sampling of quartz stockwork veinlets in altered granite at the Shoeshine prospect averaged 0.035 ounces of gold per ton over 39.7 feet.
At the Oxide Ridge prospect, samples of arsenopyritebearing quartz stockwork veins in porphyritic granitic rock averaged 0.029 ounces of gold per ton over 75 feet. Millrock also staked two claim blocks over the St. Eugene and Monte Cristo prospects. The Monte Cristo project consists of 29 claims covering an intrusiverelated gold-rich target. The St. Eugene project consists of 26 claims situated on a copper-gold-molybdenum porphyry system initially discovered in the 1970s.

International Tower Hill Mines Ltd. entered into a joint-venture agreement dated November 2, 2009, with Ocean Park Ventures Corp. on the Chisna copper-gold project in the Chistochina mining district. Among other stipulations, Ocean Park agreed to spend \$4.4 million on exploration in the first year of the agreement and $\$ 17.5$ million total over five years.

Fire River Gold conducted exploration at the Golden Zone property. Work included 1,200 feet of trenching with an excavator, geochemical sampling of the trench materials, relogging core, and geologic mapping.

In August 2009, Cook Inlet Region Inc. (CIRI) announced CIRI's underground coal gasification (UCG) project after having examined the technology for nearly a year. Laurus Energy Inc. is a partner on the Stone Horn Ridge LLC project. The project will be established on CIRI land on the west side of Cook Inlet near the Beluga River and is designed to produce syngas from coal, without mining, to fuel a 100-megawatt combined cycle power plant to supply electricity for Southcentral Alaska electricity consumers. Future UCG project phases could upgrade syngas into synthetic natural gas or clean liquid fuels. The first of three drilling programs designed to assess the coal resource and locate a specific project site was underway in 2009. Coal in the area is positioned at least 650 feet below the surface and appears to be isolated from fresh water aquifers.

Geohedral LLC in 2009 staked 521 federal mining claims contiguous to the more than 75 square miles of federal and state lands staked in 2008 by the company along the shore of the Gulf of Alaska near Yakutat. The claims cover black sand deposits with magnetite, ilmenite, rutile, and potentially meaningful quantities of gold, silver, and other precious metals. Geohedral dug or drilled 30 holes ranging from 3.5 to 27.1 feet deep, with a spacing of one-half mile over the central part of the claims. Thirty additional shallow holes ranging from 3 to 6 feet deep were dug near Tanis Mesa. A total of 242 samples were collected and assayed for gold, silver, platinum, and palladium. Two slim core holes were drilled on the south side of Tanis Mesa, one to 12.0 feet and the other to 50.3 feet, and 91 samples were assayed for gold, silver, platinum, and palladium. Geohedral reported that the unconsolidated materials above bedrock in the Tanis Mesa area average 0.30 ounces of gold per ton and 0.75 ounces of silver per ton. 
The Alaska Division of Geological \& Geophysical Surveys conducted geologic mapping in the Slate Creek area of the Chistochina mining district.

Diamond Gold Corp. continued exploration for diamonds, gemstones, and gold in the Yenlo Hills.

Limited placer gold exploration was reported by 32 individuals or companies in the region. Small-scale lode exploration was also reported at the Cliff Mine, Nugget Creek, Beaver Creek, and King \& Queen claims.

\section{SOUTHWESTERN REGION}

Donlin Creek LLC expended approximately $\$ 25.3$ million on the Donlin Creek project for prefeasibility and other studies. Work focused on geotechnical drilling for the location of mine facilities and a water storage dam in American Creek, environmental baseline data collection, community advisory meetings, and various optimization studies. A NI 43-1-01 compliant technical report on the Donlin Creek property prepared by AMEC Americas Ltd. announced that the property contains one of the largest gold deposits in the world, with 29.3 million ounces of gold in proven and probable reserves and 6 million additional ounces of gold in measured and indicated resources, at an approximate grade of 0.069 ounces of gold per ton. Based on the 2009 feasibility study, construction of the proposed Donlin Creek Mine would cost $\$ 4.48$ billion, and during the first five full years of production, the mine is expected to produce an average of 1.6 million ounces of gold annually with an average total cash cost of $\$ 394$ per ounce over a projected 21-year mine life. These projected costs place mining at Donlin Creek in the lower quartile for global industry total cash costs. The report also projects a payback of investment costs after 15 years of mining with an average gold price of $\$ 725$ per ounce, or a 5-year return of investment at a gold price of $\$ 1,000$ per ounce.

The proposed mine would process about 60,000 tons per day. The report assumes Donlin Creek ores will be processed by crushing and milling followed by flotation, pressure oxidation, and carbon-in-leach (CIL) recovery. Total gold recovery is expected to average 89.5 percent, based on the combined life-of-mine average recovery of 92.6 percent from flotation and 96.6 percent from pressure oxidation of the concentrate. The process plant design uses the most current technology for both the process systems and equipment selection. Particular attention was paid to incorporating state-of-the-art technology for safety and environmental protection.

Donlin Creek mine is expected to draw an average of 127 megawatts (MW) of electrical power sourced from a combination of on-site combined cycle gas turbine generators and wind co-generation. In an effort to optimize energy costs and reduce environmental impact, an average of 7.5 percent of annual energy requirements is expected to come from 14 wind turbine generators.

Key infrastructure for the mine includes a port on the Kuskokwim River, an access road connecting the port to the mine site, an airstrip, camp accommodations, the mine and plant site area, the tailings facility, and supporting turbine generator and wind power facilities. Cargo and supplies would be shipped on ocean barges to a port on the Kuskokwim River, barged upriver, and then transported via truck along the 76-mile access road to the mine site.

The Pebble copper-gold-molybdenum project remained the largest exploration project in Alaska, with an announced 2009 budget of $\$ 70$ million. The budget, approximately 50 percent of the project's 2008 budget, included \$20 million for drilling, \$14 million for environmental studies, and \$36 million for engineering, cultural, community outreach, and other prefeasibility studies. Approximately $\$ 452$ million has been spent on exploration at the Pebble project by Northern Dynasty Minerals Ltd., Anglo American Exploration (USA) Inc., and Pebble Limited Partnership from 2000 through 2009. A global resource for the Pebble West and Pebble East deposits was announced, with a measured and indicated resource of 5.617 billion tons grading 0.43 percent copper, 0.010 ounces of gold per ton, and 256 parts per million molybdenum; and an inferred resource of 4.374 billion tons grading 0.27 percent copper, 0.008 ounces of gold per ton, and 220 parts per million molybdenum. The total global resource contains approximately 72 billion pounds of copper, 94 million ounces of gold, and 4.8 billion pounds of molybdenum. The 2009 exploration and resource drilling program included condemnation drilling in the area of site facilities for completion of prefeasibility mine planning and exploration drilling outside of the main Pebble resource area. Drilling was completed in two phases that took place during MayJune and August-October. Approximately 34,940 feet of drilling was completed in 36 holes.

Engineering, metallurgy, infrastructure, environmental, cultural, and socioeconomic studies continued through the year. The 2009 engineering program was designed to assess a range of options to optimize the project scale, including trade-off studies of major project components; metallurgical studies to determine the optimal conventional processing systems and designs; and evaluations of the major infrastructure elements to identify the optimum alternatives and designs for these projects. Baseline hydrology, water quality, and fish resource studies continued, and will be used in an Environmental Baseline Document. An active program of stakeholder outreach also continued.

Anglo American PLC Chairman Sir Mark MoodyStuart visited Iliamna and Dillingham on a tour of Alaska concerning Anglo's 50 percent stake in the Pebble 
project. Residents near the mining project voiced support and concern about potential mine development in southwestern Alaska. Meetings scheduled for Naknek, Newhalen, and Anchorage were canceled after delays caused by unruly weather and eruptions of Redoubt Volcano.

Newmont Exploration Ltd. conducted exploration across southwestern and western Alaska. Extensive work including geologic mapping and soil and rock sampling was completed on several mining claim blocks, including Banner Creek, Sugarloaf Mountain, Marvel Creek, Tatalina River area, and Mount Joaquin.

In August, Full Metal Minerals, in alliance with Kinross Gold, entered into mining exploration license letter agreements with Calista Corp. to acquire 100 percent of the mineral rights to the Russian and Horn Mountain gold-silver properties. A 4,291-foot, 13-hole diamond drilling program was completed on the Russian Mountain property at the Owhat, Louise, and Headwall prospects. Gold-silver-copper-arsenic mineralization associated with quartz-tourmaline veining was encountered in all holes at the Owhat prospect. Best drill results were at the Owhat prospect, including drill hole RM-01, which intersected 0.251 ounces of gold per ton, 5.414 ounces of silver per ton and 6.03 percent copper over 3.3 feet true width; and drill hole RM-09, including 0.251 ounces of gold per ton, 19.836 ounces of silver per ton and 10.35 percent copper over 1.7 feet true width. Full Metal and Kinross notified Calista that they intended to drop the Russian and Horn Mountain property agreements.

Liberty Star contracted Geotech Ltd. to fly a ZTEM (Z Axis Tipper Electromagnetic System) helicopterborne geophysical survey over the Big Chunk porphyry copper property. The survey consisted of 780 line miles of ZTEM with 825-foot line spacing and very detailed airborne magnetic survey. Geotech also completed work on the Bonanza Hills property.

Mantra Mining Inc. acquired the Golden Lynx properties from Cougar Gold LLC, a Denver-based subsidiary of Electrum Ltd. The Golden Lynx properties-Kisa, Gold Lake, Gossan Valley, Little Swift and Gold Creek claim groups-were acquired from Gold Crest Mines Inc. by Electrum in 2008. The option was rescinded by year's end.

International Tower Hill Mines dropped their BMP property southeast of McGrath.

XS Platinum Ltd. continued to evaluate the tailings from past platinum mining operations in the Goodnews Bay area. An announced sale of all assets to Victory West Moly Ltd. in 2009 was not completed. The XSP multi-year sampling program conducted by Watts, Griffis, and McQuat (WGM) included a drill program using a 10-inch drill, with sample concentrates sent to Lakeshore Labs for assay and beneficiation work. In 2009, a 300-ton-per-hour test plant operating 20 hours a day, six days a week was put into production from July to October under the control of WGM. The bulk-sampling program processed mine tailings in and around the Salmon River, Squirrel Creek, and Platinum Creek. Tailings mined from the Squirrel and Platinum creek areas near the mining camp were processed and the areas reclaimed to facilitate camp expansions in the mined and reclaimed areas.

Blackpeak LLC conducted mapping and geochemical sampling at the Quicksilver Prospect in the Kilbuck Mountains. Results were not announced for 76 rock samples collected for geochemical analysis.

Five individuals or companies reported placer gold exploration work in the southwestern region. Ben Porterfield also reported bedrock trenching on Ben's Vein on the Terra property.

\section{SOUTHEASTERN REGION}

Coeur Alaska Inc. continued exploration drilling at the Kensington Mine project. A new vein named the Kimberly Vein was discovered as part of a 14-hole, 4,086-foot drilling program. Eight of the core holes encountered significant gold mineralization in Kensington-style veins.

Hecla Mining Co. completed approximately 39,000 feet of underground in-fill and exploration drilling at Greens Creek Mine. The drilling tested the peripheries of known zones including the 5250, Deep 200 South and the NWW-South zones in the mine, resulting in a replacement of tons mined during 2009. Hecla continues to be encouraged with the NE contact, a relatively new target area adjacent to mine infrastructure. Five exploration holes, including three from surface near the 920 Portal, were drilled through the targeted contact horizon and encountered disseminated and stringer mineralization in highly altered rocks with local intervals of low-grade silver mineralization. The last drill hole in the program intersected massive and semi-massive pyrite mineralization over a 20-foot interval. These results suggest proximity to a new massive sulfide body.

Constantine Metal Resources Ltd. focused on a 10hole, 15,233-foot drill program at the Palmer project. The drilling expanded South Wall Zone mineralization by 260 feet along strike, 295 feet vertically downdip, and 130 feet updip, for a total horizontal strike length of 1,250 feet and a total vertical extent of 1,350 feet. The continued expansion of the area of South Wall and RW mineralization, in conjunction with downhole geophysical results, identified specific target areas for future drilling with potential to significantly expand the sulfide zones. Downhole 3D Time Domain Electromagnetic (TDEM) surveys were completed on eight of 
ten holes drilled during the 2009 program. Preliminary, metallurgy-focused mineralogical work and metallurgical benchmarking was completed on six core samples of South Wall Zones I and II mineralization by SGS Vancouver Advanced Mineralogy Facility in association with SGS Lakefield Research Ltd. The analyses indicated coarse-grained mineralogy with good recoveries to high-grade concentrates. Constantine announced an inferred resource of 5.24 million tons grading 1.84 percent copper, 4.57 percent zinc, 0.008 ounces of gold per ton, and 0.849 ounces of silver per ton.

Ucore Uranium Inc., through subsidiary Rare Earth One, completed 27 core holes totaling 9,318 feet at Bokan-Dotson Ridge near Ketchikan. The drilling focused primarily on the road-accessible Dotson Trend, with additional drilling at the Geoduck, Cheri, and Sunday Lake areas. Rare-earth-element (REE) mineralization was encountered in 22 holes and the mineralization has an unusually high ratio of heavy REEs (Europium, Gadolinium, Terbium, Dysprosium, Holmium, Erbium, Thulium, Ytterbium, Lutetium, and Yttrium) constituting approximately one-half of the total REE content. Drilling at the Sunday Lake prospect confirms the presence of significant heavy REE mineralization, with 15.75 feet of 0.10 percent light REEs and 1.73 percent REEs in drill hole LM09-65. Drilling at the Dotson Trend suggests that mineralization occurs along a strike length of at least 2 miles and consists of multiple sub-parallel REE-bearing peralkaline dikes and veins localized by shear zones collectively comprising a steeply-dipping mineralized plane. Mineralogical studies identified coffinite and uranothorite as the dominant uranium-bearing minerals, and tombarthite, limoriite, synchisite, and bastnaesite as the dominant REE-bearing minerals at the Bokan Mountain property.

Committee Bay Resources Ltd. completed a consolidation and the restructured company changed its name to CBR Gold Corp. CBR Gold announced an updated NI 43-101 compliant resource for the Niblack precious-metals-rich volcanic massive sulfide deposit, using a $\$ 50$ net smelter return cutoff. The resource is based on 139,500 feet of drilling in 174 core holes and was completed by SRK Consulting (Canada) Inc. The indicated resource contains 2.87 million tons grading 1.18 percent copper, 2.19 percent zinc, 0.068 ounces of gold per ton, and 0.968 ounces of silver per ton. The inferred resource is 1.87 million tons grading 1.55 percent copper, 3.17 percent zinc, 0.061 ounces of gold per ton, and 0.950 ounces of silver per ton. Metallurgical test work on composite drill core samples led to the increased resources, and demonstrate greater than 90 percent copper, greater than 60 percent gold and silver, and greater than 90 percent zinc recoveries in copper and zinc concentrates. The latest test results are significantly better than past results for metal recoveries on Niblack deposit samples. CBR Gold also staked 150 federal mining claims adjacent to its existing claims at the Niblack property.

CBR Gold and the Hunter Dickinson Group completed a joint-venture agreement for the Niblack property in mid year. Heatherdale Resources Ltd., a privatelyowned subsidiary of Hunter Dickinson Group, agreed to spend $\$ 15$ million over the next three years for a 51 percent stake in the Niblack project. Heatherdale can earn up to 70 percent ownership in the Niblack property by meeting other work commitments. CBR Gold Corp. and joint-venture partner Heatherdale began a 25,000-foot underground drilling program in October on the Niblack project. Thick intersections of high-grade copper-gold-zinc-silver massive sulfide mineralization were announced for the initial holes. Hole UO31 returned the longest announced interval, 143.7 feet grading 0.088 ounces of gold per ton, 2.22 ounces of silver per ton, 2.25 percent copper, and 5.52 percent zinc.

Copper Ridge Explorations Inc. signed an option agreement with Quaterra Resources Inc. to earn up to a 65 percent interest, in stages, in the Duke Island copper-nickel-platinum-palladium property. Work commitments include spending up to $\$ 5$ million on exploration by December 31, 2013. Copper Ridge conducted a surface mapping and sampling program over the core of the main Marquis prospect and extended the Natural Source Audio-frequency Magnetotellurics (NSAMT) survey over the relatively unexplored Monte prospect to the south.

Mosam Capital Corp., in joint venture with Full Metals, funded an IP geophysical survey program at Kasaan, consisting of 6.2 line miles covering the historical Mount Andrew Mine.

Bravo Venture Group Inc. planned a 3,280-foot, two- or three-drillhole program at the Woewodski Island precious-metal-rich, volcanogenic massive sulfide project. The program was designed to test the center of the east-west-trending axis of the modeled East Lake "paleo-graben." Bravo relinquished its right to the property in August.

Four individuals or companies reported limited placer gold exploration. Five individuals or companies reported limited lode gold exploration activities.

\section{ALASKA PENINSULA}

Full Metal Minerals conducted minimal work on the Bee Creek and Kawisgag properties while seeking joint-venture partners.

Two companies reported exploration work in 2009 on claim groups in this region. Beach sands were evaluated on Trinity Island. A ground magnetic survey was completed on the Lucky Friday, Bunker, and Sunshine claims. 


\section{DEVELOPMENT}

The development sector of the mining phases as used in this report refers to building infrastructure or activities that facilitate production of mineral products. Development expenditures refer to actual expenditures at mines as well as sustaining capital. Sustaining capital includes equipment replacement and rebuilding, facility upgrades, and other expenditures that must be amortized or depreciated in accordance with tax laws.

Reported and estimated development expenditures in 2009 were approximately $\$ 330.8$ million, a 16.5 percent decrease from the 2008 value of $\$ 396.2$ million. A total of 27 projects reported development expenditures for 2009. Significant development expenditures were noted at Red Dog Mine, Fort Knox Mine, Pogo Mine, Rock Creek Mine, Greens Creek Mine, Kensington gold project, and Chuitna coal project. Development employment in 2009 was estimated to be 371 full-time-equivalent employees, a 28 percent decrease from the estimated 516 full-time-equivalent employees in 2008.

Table 9 shows development investment and regional employment. Table 10 compares the 2009 investment with that of the previous 27 years by commodity. Figure 12 shows the locations of selected development projects. Development activity was reported in all regions.

\section{NORTHERN REGION}

Total development expenditures in the region in 2009 amounted to $\$ 30.0$ million reported by three projects-Teck Cominco at Red Dog Mine and two placer operations - a 33 percent decrease from the $\$ 45.0$ million spent on development in this region in 2008. Total full-time-equivalent 2009 employment associated with these expenditures was 44 .

\section{Red Dog Mine}

Major capital projects at Red Dog in 2009 included \$15 million for tailings dams construction and \$14 million on other sustaining capital projects including mill design studies, SEIS, and other scoping studies. Additional drilling and capital expenditure decisions are pending completion of reservoir calculations by a thirdparty engineering firm. The results of this analysis are anticipated to be available in the second quarter of 2010.

Teck Alaska Inc. and NANA Regional Corp. Inc. are proposing to continue mining operations through 2031 by extending mining activity into the Aqqaluk deposit, adjacent to the Main deposit. The Aqqaluk deposit contains 51.6 million tons of reserves, with 16.7 percent zinc and 4.4 percent lead, and represents an estimated

Table 9. Reported mineral development expenditures and employment in Alaska by commodity and region, 2009.

\begin{tabular}{|c|c|c|c|c|c|c|c|c|c|c|c|}
\hline & Northern & Western & $\begin{array}{l}\text { Eastern } \\
\text { Interior }\end{array}$ & $\begin{array}{l}\text { South- } \\
\text { central }\end{array}$ & $\begin{array}{r}\text { Sot } \\
\text { wes }\end{array}$ & $\begin{array}{l}\text { uth- } \\
\text { tern }\end{array}$ & $\begin{array}{l}\text { South- } \\
\text { eastern }\end{array}$ & $\begin{array}{r}\text { Al } \\
\text { Pen }\end{array}$ & $\begin{array}{l}\text { iska } \\
\text { nsula }\end{array}$ & & Total \\
\hline \multicolumn{12}{|c|}{ Development Expenditures } \\
\hline Base metals & $\$ 29,000,000$ & -- & - - & $\$$ & $\$$ & -- & - - & $\$$ & -- & $\$$ & $29,000,000$ \\
\hline Polymetallic & -- & - - & - - & - & & - - & $17,500,000$ & & -- & & $17,500,000$ \\
\hline \multicolumn{12}{|l|}{ Precious metals } \\
\hline Placer $^{\mathrm{C}}$ & $1,000,000$ & 180,000 & 98,334 & 37,500 & & -- & 301,600 & & - - & & $1,617,434$ \\
\hline Lode & - - & $24,273,708$ & $203,100,000$ & - & & -- & $48,029,000$ & & - - & & $275,402,708$ \\
\hline Coal and peat & - - & - - & W & W & & -- & - - & & - - & & $6,800,000$ \\
\hline Industrial minerals & - - & -- & - - & 270,000 & & -- & - - & & - - & & 270,000 \\
\hline Other & - & -- & -- & 225,250 & & -- & -- & & -- & & 225,250 \\
\hline TOTAL & $\$ 30,000,000$ & $\$ 24,453,708$ & $\$ 203,198,334$ & $\$ 532,750$ & $\$$ & - & $\$ 65,830,600$ & $\$$ & - & & $330,815,392$ \\
\hline \multicolumn{12}{|c|}{ Development Employment } \\
\hline \multicolumn{12}{|l|}{ Employment } \\
\hline Workdays & 11,520 & 5,794 & 32,930 & 4,853 & & 0 & 41,283 & & 0 & & 96,380 \\
\hline Workyears $^{\mathrm{a}}$ & 44 & 22 & 127 & 19 & & 0 & 159 & & 0 & & 371 \\
\hline \multirow{2}{*}{\multicolumn{12}{|c|}{$\begin{array}{l}\text { No. of companies } \\
\text { reporting }\end{array}$}} \\
\hline & 3 & 3 & 10 & 7 & & 0 & 4 & & 0 & & 27 \\
\hline
\end{tabular}

aBased on 260-day work year. Total based on non-rounded numbers. Full-time equivalent employees per year.

${ }^{b}$ Some companies are active in more than one area/commodity.

- - = No expenditures reported.

$\mathrm{W}=$ withheld. Data included in state total.

'Some companies reported development work but did not give an amount for the expenditure; these companies are listed as reporting, but the amounts spent are unknown and are not included in the development expenditures total. 
20 years of additional mining for the region and NANA. To meet the requirements of the National Environmental Policy Act, a Supplemental Environmental Impact Statement (SEIS) was completed to evaluate the environmental effects associated with development of the Aqqaluk deposit and new circumstances or information relevant to environmental concerns that have arisen since the 1984 EIS. On December 5, 2008, the U.S. Environmental Protection Agency (EPA) announced the availability of the draft SEIS and the start of a 60-day public comment period.

On December 15, 2009, the State of Alaska issued a certification of Red Dog's National Pollutant Discharge Elimination System Permit (NPDES Permit), the mine's water discharge permit. The NPDES Permit is issued by the EPA and certified by the State under Section 401 of the U.S. Clean Water Act. Other State and local permits required for the development of Aqqaluk were received in December 2009. The appeal period for those permits has expired. Teck stated that a wetlands permit from the Army Corps of Engineers was the only outstanding agency authorization, and that the permit was undergoing final agency review.

Teck plans to start pre-stripping of the Aqqaluk deposit in 2010 on receipt of the SEIS and the new NPDES and other required permits. The Aqqaluk deposit is expected to be the main ore supply for the mine for the next 20 years, from 2011 onward, according to Teck.

\section{WESTERN REGION}

Development expenditures were reported for lode and placer projects. Five projects reported expenditures amounting to approximately $\$ 24.45$ million for 2009 , which compares to development expenditures of $\$ 124.9$ million for 2008, a decrease of 80 percent. Total 2009 employment associated with these expenditures was 22 full-time-equivalent employees.

Table 10. Reported mineral development expenditures in Alaska by commodity, 1982-2009.

\begin{tabular}{|c|c|c|c|c|c|c|c|}
\hline Year & $\begin{array}{c}\text { Base } \\
\text { metals }\end{array}$ & Polymetallics & $\begin{array}{c}\text { Precious } \\
\text { metals }\end{array}$ & Gemstones $^{\mathrm{a}}$ & $\begin{array}{c}\text { Industrial } \\
\text { minerals }\end{array}$ & $\begin{array}{c}\text { Coal and } \\
\text { peat }\end{array}$ & Total \\
\hline 1982 & $\$ 10,270,000$ & N/A & $\$ \quad 19,320,000$ & & $\$ 4,251,000$ & $\$ 7,750,000$ & $41,591,000$ \\
\hline 1983 & $19,500,000$ & N/A & $7,112,500$ & & $1,000,000$ & 250,000 & $27,862,500$ \\
\hline 1984 & $10,710,500$ & N/A & $15,058,555$ & & 579,000 & $27,000,000$ & $53,348,055$ \\
\hline 1985 & $13,000,000$ & N/A & $16,890,755$ & & $1,830,000$ & $2,400,000$ & $34,120,755$ \\
\hline 1986 & $3,260,800$ & $8,000,000$ & $12,417,172$ & & 124,000 & 530,000 & $24,331,972$ \\
\hline 1987 & $38,080,000$ & $48,000,000$ & $13,640,848$ & & 188,000 & 342,000 & $100,250,848$ \\
\hline 1988 & $165,500,000$ & $69,000,000$ & $40,445,400$ & & -- & -- & $274,945,400$ \\
\hline 1989 & $118,200,000$ & 411,000 & $6,465,350$ & & $7,000,000$ & $2,196,000$ & $134,272,350$ \\
\hline 1990 & -- & $4,101,000$ & $7,136,500$ & & 30,000 & $3,079,000$ & $14,346,500$ \\
\hline 1991 & -- & $8,000,000$ & $14,994,350$ & & 262,000 & $2,318,000$ & $25,574,350$ \\
\hline 1992 & 80,000 & $4,300,000$ & $23,151,300$ & & 404,000 & $1,655,000$ & $29,590,300$ \\
\hline 1993 & -- & $10,731,136$ & $15,103,000$ & & 433,500 & $1,400,000$ & $27,667,636$ \\
\hline 1994 & $10,000,000$ & $5,000,000$ & $27,392,850$ & & 5,000 & $2,545,000$ & $44,942,850$ \\
\hline 1995 & $11,200,000$ & $9,590,000$ & $127,165,750$ & & 426,000 & 200,000 & $148,581,750$ \\
\hline 1996 & $60,000,000$ & $60,100,000$ & $273,042,000$ & & 495,000 & 400,000 & $394,037,000$ \\
\hline 1997 & $133,880,000$ & $7,300,000$ & $26,299,000$ & & 500,000 & 410,000 & $168,389,000$ \\
\hline 1998 & $28,000,000$ & $5,600,000$ & $15,602,000$ & & $5,355,000$ & 850,000 & $55,407,000$ \\
\hline 1999 & $12,500,000$ & $2,500,000$ & $15,864,000$ & & 400,000 & $2,575,000$ & $33,839,000$ \\
\hline 2000 & $100,000,000$ & $16,400,000$ & $24,699,000$ & & 611,000 & -- & $141,710,000$ \\
\hline 2001 & $43,800,000$ & $3,300,000$ & $32,719,000$ & & 300,000 & $1,040,000$ & $81,159,000$ \\
\hline 2002 & -- & $5,700,000$ & $26,655,000$ & & 250,000 & $1,450,000$ & $34,055,000$ \\
\hline 2003 & -- & -- & $38,839,332$ & & 315,000 & -- & $39,154,332$ \\
\hline 2004 & $17,700,000$ & $6,215,000$ & $177,440,081$ & & $4,991,434$ & $2,760,000$ & $209,106,515$ \\
\hline 2005 & $28,000,000$ & $16,700,000$ & $301,011,469$ & & 856,500 & $1,350,000$ & $347,917,969$ \\
\hline 2006 & $31,200,000$ & $26,183,280$ & $420,759,203$ & & $1,566,000$ & $15,985,000$ & $495,693,483$ \\
\hline 2007 & $41,374,880$ & $30,766,902$ & $239,931,040$ & & $1,320,500$ & $5,385,000$ & $318,778,322$ \\
\hline 2008 & $45,000,000$ & $24,000,000$ & $319,702,594$ & & 205,113 & $7,260,000$ & $396,167,707$ \\
\hline $2009^{a}$ & $29,000,000$ & $17,500,000$ & $277,020,142$ & 225,250 & 270,000 & $6,800,000$ & $330,815,392$ \\
\hline TOTAL & $970,256,180$ & $\$ 389,398,318$ & $\$ 2,535,878,191$ & $\$ 225,250$ & $\$ 33,968,047$ & $\$ 97,930,000$ & $\$ 4,027,655,986$ \\
\hline
\end{tabular}

$\mathrm{N} / \mathrm{A}=$ Figures not available prior to 1986 .

-- Not reported

${ }^{\mathrm{a}} \mathrm{Gemstone}$ development category added in 2009 . 
Rock CReek Mine

NovaGold's Nome properties include Rock Creek, Big Hurrah, and a significant holding of placer and gravel deposits.

The most advanced property is the Rock Creek gold mine. Construction at the mine is nearly complete and is designed to produce approximately 100,000 ounces of gold annually, based on the existing 0.5 million ounces of probable gold reserves, 1.9 million ounces of measured and indicated resources, and 0.3 million ounces of inferred gold resources at the three properties.

Construction at Rock Creek began in the summer of 2006, and Rock Creek Mine received regulatory authorizations and began the commissioning process in September 2008. Production at Rock Creek began on September 19, 2008, with the 7,100-ton-per-day mill being fed at 25 percent capacity. The mill operated until October 9, when the ball mill resistor packs burned out, shutting the mill down. The mill was recommissioned on November 12 and operated until November 24, at which time operations were suspended. A total of 100,000 tons of ore were milled in 2008.

The Rock Creek mine is currently on care and maintenance status. NovaGold anticipates staffing Rock Creek with approximately 14 employees during the temporary closure. NovaGold states that it is completing a

\section{Northern Region}

1. Red Dog-Teck Resources Ltd.-Permitting, tailings improvement, mill design studies

\section{Western Region}

2. Rock Creek-NovaGold Resources Inc.-Water management, structure improvements

3. Nome placers

4. Nixon Fork-Fire River Gold Corp./Pacific North West Capital - Comprehensive re-evaluation studies

III Eastern Interior Region

5. Fort Knox gold mine-Kinross Gold Corp.-Phase 7 dewatering and stripping, upgrade mill

6. Placer gold

7. Pogo mine-Teck \& Sumitomo-Underground development, camp construction, tailings dam grouting

8. Usibelli Coal Mine Inc.

9. Placer gold

\section{Southwestern Region}

VI Alaska Peninsula Region

Figure 12. Selected development projects, 2009. detailed review process to evaluate start-up requirements for the Rock Creek project, but does not currently plan to initiate start-up activities in 2010. NovaGold is also considering selling the mine.

According to NovaGold, 2009 expenditures at the Rock Creek project totaled approximately \$24.3 million.

NovaGold reported in 2009 that the company was focused on improving the project's water management structures and action plan to ensure the project remains in compliance with all environmental regulations during the spring thaw and runoff period.

Probable reserves at Rock Creek and satellite Big Hurrah are 8.6 million tons at a grade of 0.0379 ounces of gold per ton and 1.32 million tons at 0.140 ounces of gold per ton, respectively (table 11).

\section{NixOn Fork Mine}

The Nixon Fork gold-copper mine is approximately 35 miles northeast of McGrath. It was owned by Mystery Creek Resources Inc., a wholly-owned subsidiary of St. Andrew Goldfields Ltd. The mine was closed in October 2007 pending additional exploration drilling and efforts to sell the operation. No development was reported for 2008. On December 18, 2008, Pacific North West Capital Corp. announced that it had acquired an option, exercisable until February 15, 2009, to purchase

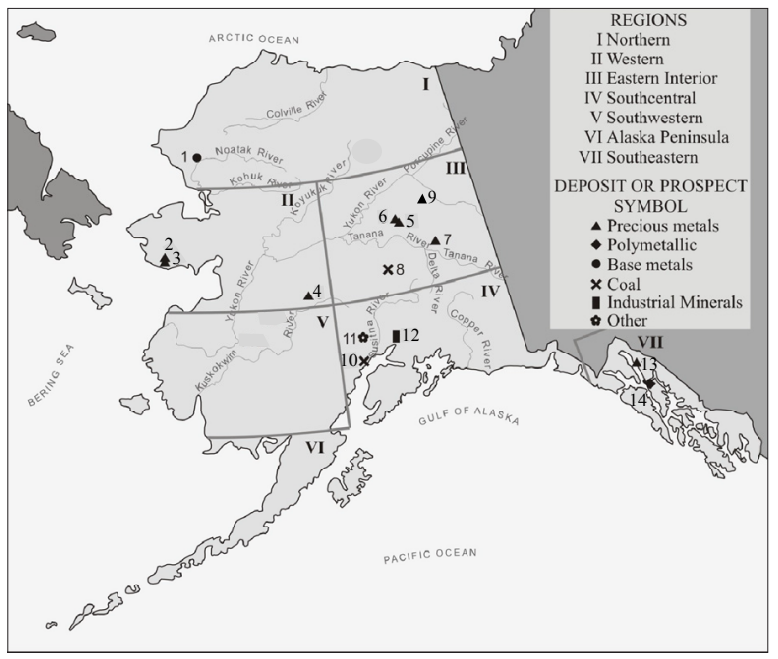

IV Southcentral Region

10. Chuitna Coal-PacRim Coal LP-Studies, permitting

11. Gemstone development-Road construction

12. Industrial minerals - Various

VII Southeastern Region

13. Kensington-Coeur Alaska Inc.-Permitting, tailings facilities, road improvements

14. Greens Creek-Hecla-Underground development 
Table 11. Gold reserves and resources at Rock Creek, Big Hurrah, and various NovaGold holdings at Nome, as of December 22, 2009 and as of June 1, 2010.

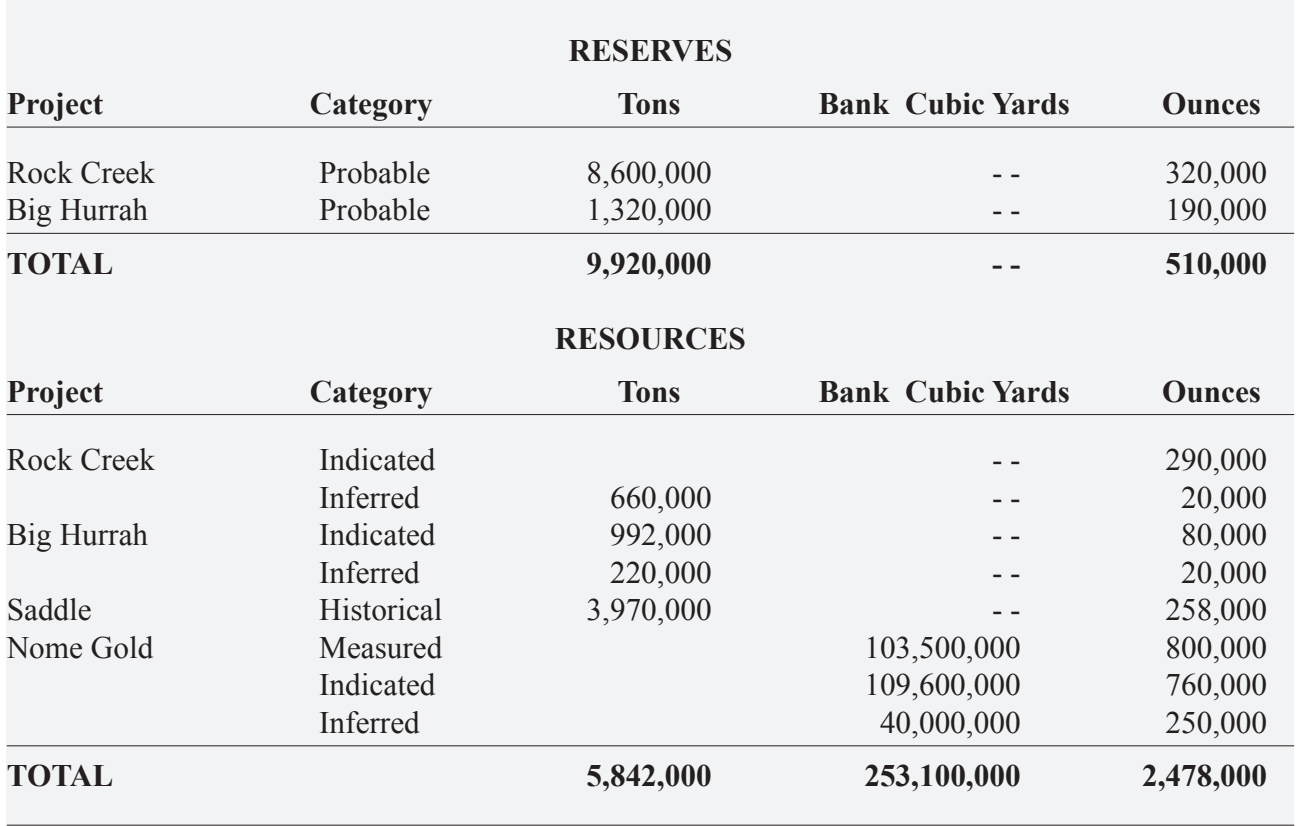

- - Not applicable.

a 100 percent interest in Mystery Creek Resources. Pacific North West Capital paid $\$ 100,000$ on signing the agreement. Subject to regulatory approval and the satisfactory completion of its due diligence review, Pacific North West Capital could exercise the option by paying an additional $\$ 400,000$, of which $\$ 100,000$ is required to be paid on closing of the purchase of Mystery Creek Resources, with the balance to be paid in three equal installments on May 1, July 1, and September 1, 2009.

On August 13, 2009, Fire River Gold Corp. announced that it was exercising its option to purchase 100 percent interest in Mystery Creek Resources Inc. from Pacific North West Capital Corp. Fire River Gold Corp. agreed to pay a total of $\$ 500,000$, a total of $\$ 2.5$ million in Fire River shares at a deemed price of $\$ 0.45$ per share, and 1 million share purchase warrants at an exercise price of $\$ 0.50$ for a period of 24 months from the date of issue. Fire River also agreed to refund all expenses incurred by Pacific North West Capital Corp. from May 1, 2009, until the finalization of the transaction, which will not exceed $\$ 1,250,000$.

Facilities at Nixon Fork Mine include a 200-ton-perday flotation plant with a gravity gold separation circuit, a sulfide flotation circuit, and a newly constructed carbon-in-leach (CIL) gold leaching circuit. The mine also includes a fleet of mining vehicles, a power plant, maintenance facilities, an 85-person camp, office facilities, and five aircraft landing strips. Mining and processing operations at Nixon Fork Mine are fully permitted and bonded. Mine stockpiles amount to 2,315 tons of ore and approximately 127,868 tons of mineralized tailings.

\section{EASTERN INTERIOR REGION}

Total construction and other capitalized expenditures allocated to the eastern interior region amounted to $\$ 203.2$ million (exclusive of coal expenditures) in 2009 , compared to $\$ 151.9$ million in 2008 , an increase of $\$ 51.3$ million, nearly 34 percent more than in 2008 . Coal expenditures shown as withheld are reflected in the total statewide expenditures.

The eastern interior region had the highest regional development spending in 2009, with ten projects reporting development activity. Estimated employment allocated to development in the region in 2009 amounted to 127 full-time-equivalent positions.

\section{Fort KNOX Mine}

Fort Knox Mine, approximately 25 miles northeast of Fairbanks, is owned and operated by Fairbanks Gold Mining Inc., a wholly owned subsidiary of Kinross Gold Corp. Fort Knox Mine includes the main Fort Knox open-pit gold mine, the mill and tailings storage facility, and the Walter Creek heap leach facility. The True North open-pit mine is currently being reclaimed. 
Activities at Fort Knox in 2009 included:

- construction of the in-heap storage pond, carbon-in-column (CIC) building, and barren and pregnant solution lines for the Walter Creek Valley Fill Heap Leach;

- initiation of Phase 7 dewatering and continued Phase 7 stripping;

- major upgrades to the mill gravity circuit and semi-autogenous grinding (SAG) drive;

- construction of a pumping system for discharge of tailings from the mill;

- initiation of construction on the Assembly Line Preventative Maintenance (ALPM) shop to support maintenance of the haul trucks;

- relocation and upgrade of the explosives magazine;

- initiation of studies regarding increasing the height of the tailings dam and geotechnical investigations in preparation for permitting the planned dam raise; and

- commencement of final reclamation of True North.

Major activities planned for 2010 include:

- completing stage 1 construction and initiating stage 2 construction of the Walter Creek Valley Fill Heap Leach;

- obtaining permits for construction of the tailings storage facility (TSF) dam raise from the Alaska Department of Natural Resources (DNR) and the U.S. Army Corps of Engineers (COE);

- excavating and reconstructing the top 22 feet of the TSF dam raise, reversing the core and preparing for additional raises in 2011 and 2013;

- acquiring 32 acres from the National Oceanic and Atmospheric Agency withdrawal for placement of waste rock;

- upgrading the Phase 6 dewatering system with a new lift station;

- completing the revision and update of the Fort Knox reclamation and closure plan and obtaining approvals of the plan from DNR, Alaska Department of Environmental Conservation (DEC), and $\mathrm{COE}$;

- completing the revision and update of the True North reclamation and closure plan and obtaining approvals of the plan from DNR; and

- completing all major earthwork activities, removal of buildings, and initial revegetation activities at True North.

Capital expenditures at Fort Knox Mine were approximately \$133.1 million in 2009 compared to $\$ 126.6$ million in 2008.
Pogo Mine

Pogo Mine began operations in 2006 with a ten-year mine life and was declared to have reached commercial production in April 2007. Underground development was required to open up the additional ore headings needed to reach the full production rate of 2,500 tons per day, which was reached in 2009 with an average production rate of 2,550 tons per day. Mining in 2009 was budgeted for 900,000 tons of ore and 13,500 feet of lateral development.

Capital expenditures at the project during 2009 included 16,771 feet of lateral drilling, exceeding the projected 13,500 lateral feet. A new 78-person camp was constructed in the lower camp area, and was fully commissioned in December 2009. A grout curtain extension was installed at the recycle tailings pond during the summer of 2009 to intercept potential seepage pathways within the south abutment bedrock that trend parallel and perpendicular to the Liese Creek Fault System. Drilling included 31 holes for a total of approximately 2,545 feet; 25,250 gallons of grout, including 113,000 pounds of cement, were used in the curtain extension. The Liese Creek diversion ditch received approximately 800 feet of shotcrete lining to decrease possible seepage. Development expenditures for 2009 are estimated to be $\$ 70$ million.

Development activity will remain high during 2010. Ramp development will continue over the next two years. Mining in 2010 is budgeted for 920,415 tons of ore and 21,000 feet of lateral development. The mining contractor will remain on site throughout 2010 with 50 employees housed in the new lower camp. Mining of additional gravel from the airstrip borrow pit will be completed on an as-needed basis to complete underground road maintenance. Additional material from Material Site 18 will be used to conduct road repairs on the remainder of the access road from Mile 0 to Mile 28. Additional planned development expenditures in 2010 include the following: the Liese Creek diversion ditch will receive further concrete lining in the summer of 2010 to help decrease possible seepage; Pogo will purchase and install a new 2,000 kW generator for backup power generation during power outages; and Pogo will design and install secondary containment around a number of structures at the mine that contain low-level cyanide contacted solutions.

\section{SOUTHCENTRAL REGION}

Development expenditures totaling \$532,750 (exclusive of coal expenditures) were reported for seven projects in 2009. This is 94 percent lower than the $\$ 7.99$ million spent in 2008. Coal expenditures shown as withheld are reflected in the total statewide expenditures. Estimated development employment in the southcentral 
region was 19 full-time-equivalent positions in 2009 compared to 44 in 2008.

Diamond Gold Corp. reported development activity including 5 miles of pioneer road construction for its Sable-Kahiltna Mine in the Yentna mining district. Four industrial minerals (rock, sand, and gravel) projects reported development activity during 2009.

\section{Chuitna Coal Project}

The largest development expenditure in the southcentral region in 2009 was by PacRim Coal LP. PacRim Coal LP continued environmental, permitting, and engineering work on the Chuitna Coal project west of Anchorage on the north side of Cook Inlet. The project is being designed to include a coal export terminal at Ladd Landing, connected to the mine with a 12-mile-long covered conveyor. Mine production capacity is designed to handle 3 to 12 million tons per year. Proven reserves are reported to be 771 million tons.

\section{SOUTHWESTERN REGION}

No companies reported development activity in 2009 in the southwestern region. This compares to three companies that reported $\$ 161,000$ in development activity in 2008 .

\section{ALASKA PENINSULA REGION}

There were no reports of development activity in 2009 in the Alaska Peninsula region. This compares with one company that reported $\$ 70,000$ in development expenditures in the area in 2008.

\section{SOUTHEASTERN REGION}

The southeastern region had one lode gold, one polymetallic, and two placer gold projects that reported development expenditures in 2009. Construction continued at the Kensington project, and Greens Creek Mine saw ongoing development throughout the year. Development expenditures in the southeastern region totaled $\$ 65.83$ million. Development-related employment in the southeast region in 2009 was approximately 159 full-time-equivalent employees.

\section{Greens Creek Mine}

Greens Creek Mine, an underground silver-zinclead-gold mine on Admiralty Island near Juneau, is operated by Hecla Greens Creek Mining Co. and produces approximately 2,100 tons of ore per day. The primary mining methods are cut-and-fill and longhole stoping. The ore is processed on site at a mill, which produces lead, zinc, and bulk concentrates, as well as doré containing silver and gold. The doré is sold to a precious metal refiner, and the three concentrate products are sold to a number of major smelters worldwide.
Concentrates are shipped from a marine terminal about 9 miles from the mine site.

During 2009, $\$ 17.5$ million was capitalized for underground development and purchases of new mobile equipment at the Greens Creek Mine and for other noncash additions. Most of the development expenditures were for drilling and preliminary production. Hecla completed approximately 39,000 feet of underground in-fill and exploration drilling at the mine. Manpower allocated to development at Greens Creek amounted to approximately 85 full-time-equivalent persons for the year.

Greens Creek Mine was powered completely by onsite diesel generators prior to 2005. An agreement was reached in 2005 to purchase excess local hydroelectric power from Alaska Electric Light and Power Company (AEL\&P). Infrastructure installation was completed in 2006, and by the third quarter of that year, hydroelectric power was in use at the mine. Although low lake levels and increased demand in the Juneau area combined to reduce the amount of power available to Greens Creek in 2007 and 2008, the mine received an increased proportion of its power from AEL\&P in 2009, after the power company was able to increase its production capacity. The combination of available hydroelectric power and lower diesel fuel prices helped decrease costs at Greens Creek in 2009.

\section{Kensington Mine}

The Kensington gold project is owned and operated by Coeur Alaska Inc., a wholly owned subsidiary of Coeur d'Alene Mines Inc. The project is located on the western and southern flanks of Lions Head Mountain; between Berners Bay and Lynn Canal; and in the drainages of Johnson, Sherman, and Slate creeks.

All major underground development activities and surface facilities at Kensington were complete by 2009 with the exception of the tailings facility. Construction of the tailings facility was delayed due to an injunction granted by the Ninth Circuit Court of Appeals in August 2006, which led to the suspension of construction activities associated with the Slate Lake Tailings Facility. On June 27, 2008, the U.S. Supreme Court granted the State of Alaska and Coeur Alaska's petitions for a writ of certiorari to review the decision relating to the Kensington 404 tailings permit. Oral arguments were presented to the Supreme Court on January 12, 2009. Care and maintenance were conducted at the site from January to June 2009, awaiting a Supreme Court decision.

The Supreme Court issued a ruling favorable to Coeur Alaska on June 22, 2009, reversing the judgment of the Ninth Circuit Court, resulting in the Ninth Circuit Court dissolving its injunction in July 2009. The Corps of Engineers issued a permit modification and lifted the suspension of the original permit on August 14, 2009. Construction activities subsequently resumed, primarily 
focused on the dam embankment and tailings treatment facility. Construction activities are scheduled to be completed in the second half of 2010 with operations beginning in the third or fourth quarter.

Additional construction activities included the installation of a new kitchen, dining, and recreational facility, partial installation of a new 120-person dorm facility, site grading for an expansion of the Comet water treatment plant, and preparatory work for the installation of an assay lab. Activities also continued toward commissioning the mill and crusher facilities. The water treatment plant, associated ponds and infrastructure received upgrades and were operated and maintained through the year in accordance with the NPDES Permit.

Underground exploration, definition, and geotechnical drilling were completed in 2009. A total of 10,426 feet of drilling was conducted in 2009 with 4,086 feet as part of the exploration program, 5,520 feet as part of the definition drilling program, and 820 feet as part of a geotechnical assessment.

Road improvements were an ongoing priority at Kensington in 2009. Road surfacing and interim reclamation seeding were major improvements to the road projects. Maintenance of storm water best management practices along the Jualin and Kensington access corridors was also a major ongoing priority for 2009 .

Coeur spent more than $\$ 48$ million for development at Kensington in 2009 and employed approximately 74 full-time employees.
No gold production occurred at the Kensington gold project during calendar year 2009. Proven and probable reserves at the project as of December 31, 2009, were $5,500,000$ tons with a grade of 0.27 ounces of gold per ton, containing 1,478,000 ounces of gold. Measured and indicated resources were 2,724,000 tons with a grade of 0.18 ounces of gold per ton, containing 494,000 ounces of gold.

Coeur plans a production rate of 120,000 ounces of gold per year at a cash cost of $\$ 475$ per ounce. Production is expected to be 40,000 ounces of gold in 2010 . The milling plant will process approximately 1,100 tons of ore per day, involving primary crushing, semiautogenous grinding (SAG), mill grinding, gravity, and flotation concentration. About 40 percent of the tailings will be returned to the mine for backfill; the remaining tailings will be sent to the selected tailings disposal facility as required by court resolution. Concentrates will be packaged and shipped offsite for final gold recovery. The mine is expected to provide approximately 225 direct jobs once it is operating.

In 2010, construction is planned to expand the existing Comet water treatment system. Tailings facility construction is planned to be completed in the second half of 2010. Coeur estimates an additional \$81.7 million in capital expenditures will be necessary to complete construction and mine-related activities at the Kensington gold project.

\section{PRODUCTION}

The value of mineral production in Alaska during 2009 is estimated at $\$ 2.456$ billion. The estimate represents an increase in value of approximately $\$ 28.43$ million, or a 1 percent increase from 2008 production values of $\$ 2.427$ billion. Note that the industrial minerals sector reflects reporting shortfalls. With the amount of production reported, there appears to be a fairly significant downturn in sand, gravel, and rock production; however, several major rock, sand, and gravel producers declined to contribute their production numbers, which are consequently not included and the estimates are known to be lower than actual production totals. Metals (gold, silver, lead, and zinc) account for \$2,318 million (about 94 percent of the total), coal and peat for $\$ 69$ million (2.8 percent of the total), and industrial minerals for $\$ 69$ million (2.8 percent of the total). Employment attributed to production in 2009 is estimated to be 2,487 full-time-equivalent positions.

Table 12 shows the estimated mineral production quantity and value for 2007 through 2009. Figures 13-15 show the historic production of sand and gravel, gold, and coal. Selected production sites are shown in figure 16.

Allocation of value of production by commodity is shown in figure 17. Zinc leads by far with the largest percent of value at 43.52 percent, with Red Dog Mine being the most significant contributor of zinc production. Gold moved forward one step to second place, carrying 30.91 percent of total value. In descending order, the values of the remaining products are lead at 10.62 percent, silver at 9.33 percent, coal and peat at 2.80 percent, and industrial minerals (rock, sand, gravel, and gemstones) at 2.81 percent.

Table 13 shows the average metal values used in this report over the last 16 years. Some respondents reported actual unit values received for production and these were used in place of those in the table. In general, however, metal values were computed from weekly averages on the London Metal Exchange, and do not take into account mining, shipping, smelting, and other costs incurred by the producer. 
Table 12. Estimated mineral production in Alaska, 2007-2009a.

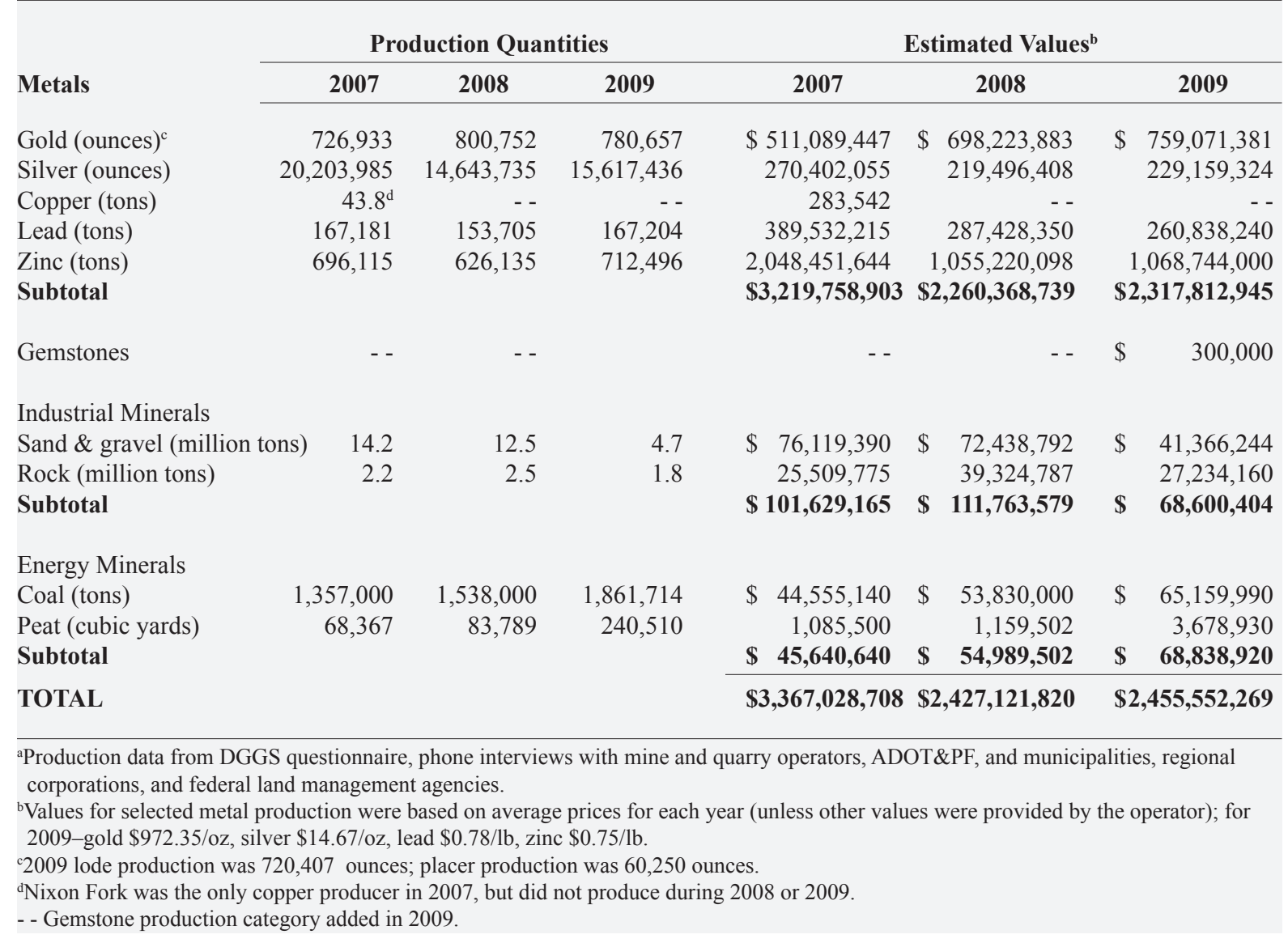

The increased mineral production value in 2009 compared to 2008 resulted primarily from increased production volumes of lead, zinc, silver, placer gold, and coal, and to the increased value of gold. Lode gold production declined compared to 2008. Average gold prices were higher in 2009 than in 2008, but silver, copper, lead, and zinc prices declined. The gold price increase was 11.51 percent; price decreases in silver, copper, lead, and zinc were 2.13 percent, 24.68 percent, 17.02 percent, and 10.71 percent, respectively.

The production estimates included in this report are from questionnaires returned by miners and mining companies, Native organizations, government agencies, municipalities, and service companies, complemented by telephone queries, emails, faxes, searches of annual reports, $10-\mathrm{K}$ reports, and news releases by producers. Additional information was derived from State of Alaska Annual Placer Mining Applications (APMAs) submitted to the Division of Mining, Land \& Water. Appendix D lists Alaskan metal producers for 2009.

The authors wish to thank the Alaska Railroad Corp., the Alaska Mental Health Trust Land Office, the
Table 13. Average metal prices, 1994-2009.

\begin{tabular}{|c|c|c|c|c|c|}
\hline & $\begin{array}{l}\text { Gold } \\
\$ / o z\end{array}$ & $\begin{array}{l}\text { Silver } \\
\$ / 0 z\end{array}$ & $\begin{array}{c}\text { Copper } \\
\text { \$/lb }\end{array}$ & $\begin{array}{l}\text { Lead } \\
\$ / l \mathbf{l b}\end{array}$ & $\begin{array}{l}\text { Zinc } \\
\text { \$/lb }\end{array}$ \\
\hline 1994 & 386.00 & 5.41 & 1.05 & 0.35 & 0.45 \\
\hline 1995 & 395.00 & 5.43 & 1.33 & 0.34 & 0.48 \\
\hline 1996 & 387.60 & 5.19 & 1.03 & 0.37 & 0.49 \\
\hline 1997 & 330.76 & 4.91 & 1.03 & 0.28 & 0.59 \\
\hline 1998 & 293.88 & 5.53 & 0.75 & 0.24 & 0.46 \\
\hline 1999 & 278.70 & 5.20 & 0.71 & 0.23 & 0.49 \\
\hline 2000 & 279.10 & 4.96 & 0.82 & 0.21 & 0.51 \\
\hline 2001 & 271.04 & 4.37 & 0.71 & 0.22 & 0.40 \\
\hline 2002 & 310.06 & 4.61 & 0.41 & 0.21 & 0.35 \\
\hline 2003 & 363.38 & 4.88 & 0.81 & 0.23 & 0.38 \\
\hline 2004 & 409.72 & 6.67 & 1.29 & 0.40 & 0.47 \\
\hline 2005 & 444.74 & 7.32 & 1.61 & 0.43 & 0.63 \\
\hline 2006 & 603.46 & 11.55 & 3.02 & 0.58 & 1.47 \\
\hline 2007 & 695.39 & 13.38 & 3.24 & 1.17 & 1.47 \\
\hline 2008 & 871.96 & 14.99 & 3.12 & 0.94 & 0.84 \\
\hline $2009^{a}$ & 972.35 & 14.67 & 2.35 & 0.78 & 0.75 \\
\hline
\end{tabular}


Alaska Department of Transportation \& Public Facilities, the Alaska Division of Mining, Land \& Water, the Alaska Department of Environmental Conservation, the Fairbanks North Star Borough, the Denali Borough, the City and Borough of Juneau, Alyeska Pipeline Service Co., the U.S. Forest Service, the U.S. Bureau of Land Management, Native regional corporations, and the many large and small Alaska mining operations that contributed data to this report.

Tables 14 and 15 show gold production by region of the state, and placer production by small, medium, and large-sized producers. Two placer operations achieved a "large sized" rating in 2009. Placer gold production in 2009 was 60,250 ounces, compared with 56,759 ounces of placer gold produced in Alaska in 2008. The Western region was the biggest placer producer in 2009 , producing an estimated 27,741 ounces, followed by the Eastern Interior region at 18,255 ounces. The Southcentral region produced an estimated 4,940 ounces of placer gold in 2009, and the Southwestern region produced an estimated 4,659 ounces. The Northern region reported production of 4,432 ounces of placer gold in

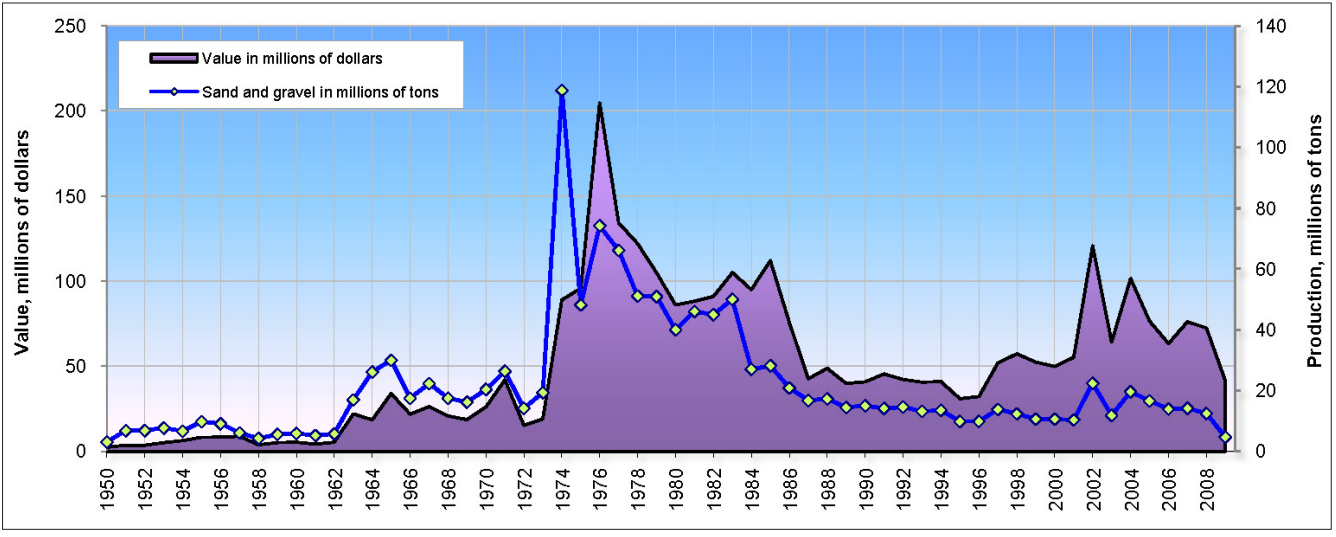

Figure 13. Sand and gravel production in Alaska 1950-2009.

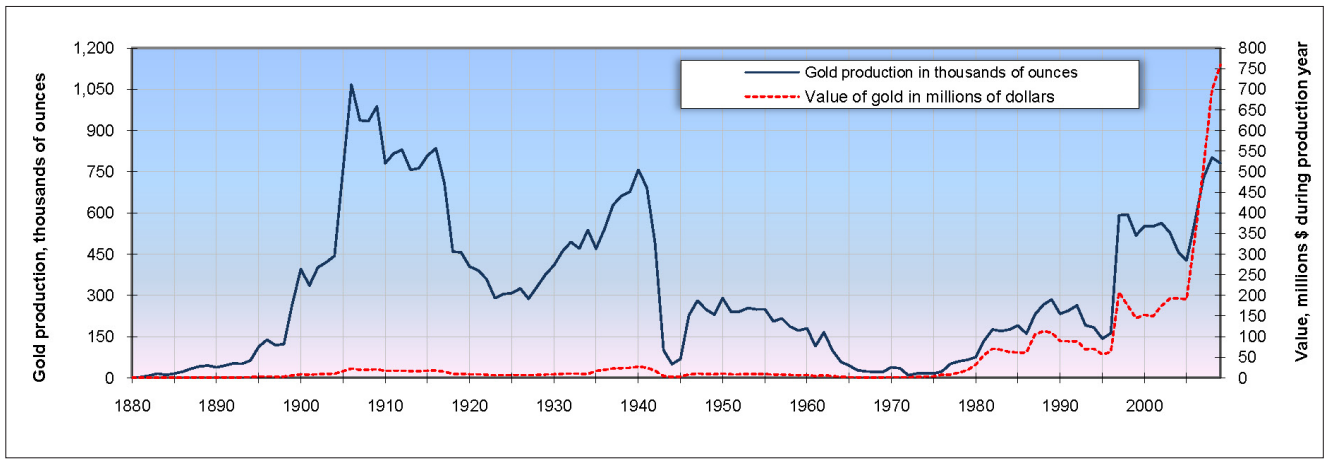

Figure 14. Amount of value of gold production in Alaska, 1880-2009.

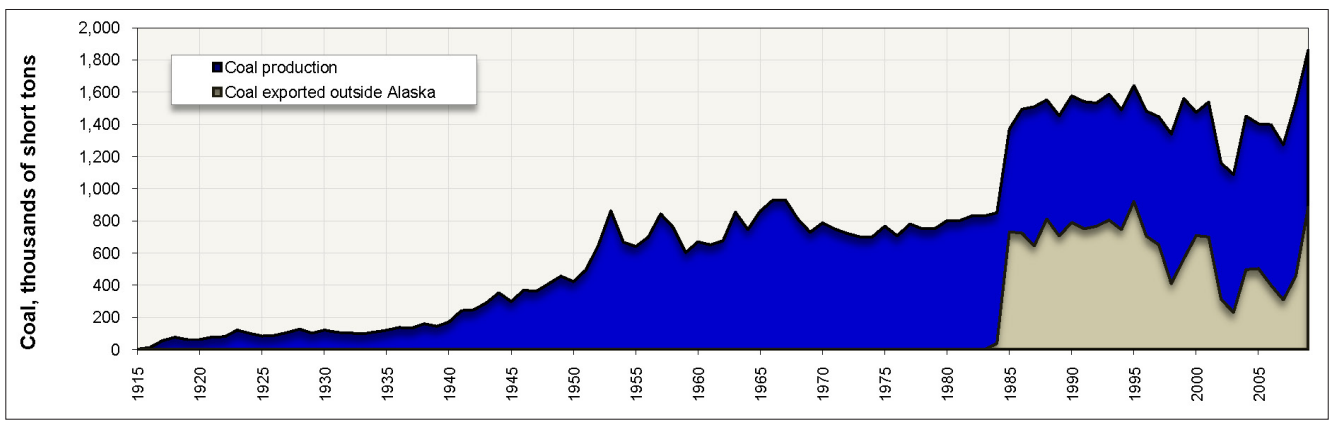

Figure 15. Coal production in Alaska, 1915-2009, including exports outside Alaska. 


\section{Northern Region}

1. Teck Cominco Alaska Inc. Red Dog Mine, Noatak district-Zinc, lead, silver (germanium, indium, cadmium)

2. Placer gold mines

3. Prudhoe Bay and Kuparuk pits (numerous)-Sand and gravel

\section{Western Region}

4. Nome-Placer gold, sand, and gravel

5. Placer gold mines

\section{Eastern Interior Region}

6. Placer gold mines

7. Polar Mining Inc., Fairbanks district-Gold, silver, screened aggregate

8. Fairbanks Gold Mining Inc., Fort Knox Mine, Fairbanks district — Gold

9. Earthmovers of Fairbanks Inc., Fairbanks district-Gold

10. Sumitomo Metal Mining Pogo LLC, Pogo Mine, Fairbanks district-Gold

11. Usibelli Coal Mine Inc., Bonnifield district-Coal

12. Placer gold mines

13. Placer gold mines

14. Placer gold mines

\section{Southcentral Region}

15. Palmer/Wasilla-Anchorage district—Sand and gravel

Figure 16. Selected production projects, 2009.

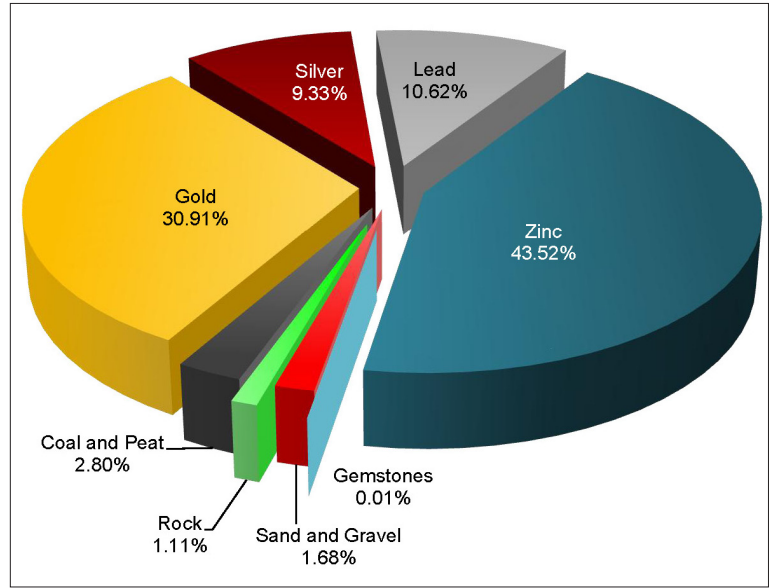

Figure 17. Alaska mineral production value by commodity.

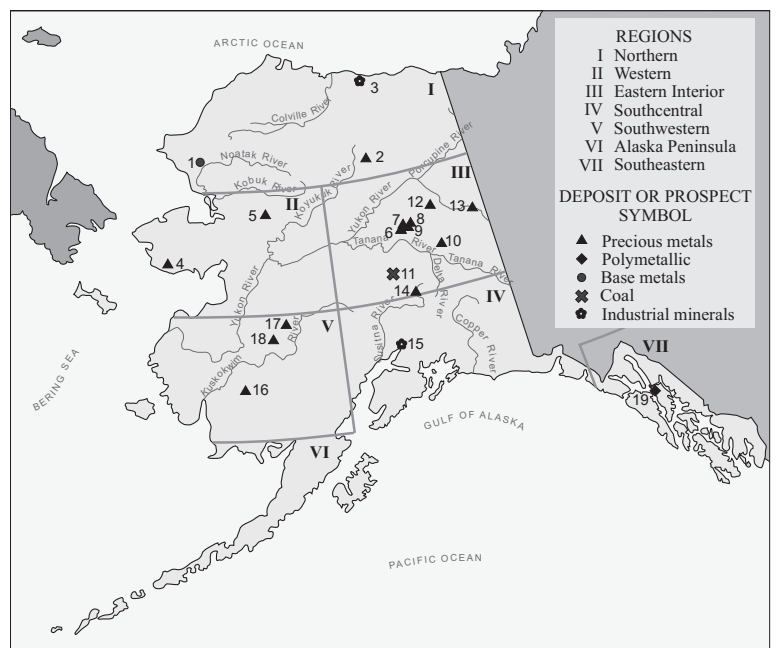

V Southwestern Region

16. NYAC Mining Co.- - Gold

17. Placer gold mines

18. Placer gold mines

\section{Alaska Peninsula Region}

VII Southeastern Region

19. Hecla Mining Co., Greens Creek Mine, JuneauAdmiralty district-Silver, zinc, gold, lead
2009 , and the Southeastern region reported production of 223 ounces. An estimated 234 placer mines operated in Alaska in 2009 compared to 195 in 2008, an increase of 20 percent. Total employment in the placer industry in 2009 is estimated at 435 , including recreational sized operations, compared with approximately 312 full-time equivalent employees in 2008, a 39 percent growth from 2008 levels.

Tables 16 and 17 show the value and regional importance of sales of sand and gravel, and rock stockpiling. The nonmetallic (rock, sand, gravel, and peat) sector suffered what appears to be a loss of production during the year, but it is likely primarily due to reporting shortfalls. The value of the sector for 2009 is currently estimated to be $\$ 68.6$ million compared to a value of $\$ 112.9$ million in 2008, a decrease in value of 39 percent. Employment in 2009 is estimated to be 369 , compared with a final estimate of 377 in 2008. 
Table 14. Reported refined gold production, number of operators, and industry employment in Alaska, 2007-

\begin{tabular}{|c|c|c|c|c|c|c|c|c|c|}
\hline \multirow[b]{2}{*}{ Region } & \multicolumn{3}{|c|}{ Number of operators } & \multicolumn{3}{|c|}{ Production in ounces } & \multicolumn{3}{|c|}{ Number of employees ${ }^{b}$} \\
\hline & 2007 & 2008 & 2009 & 2007 & 2008 & 2009 & 2007 & 2008 & 2009 \\
\hline Northern & 18 & 20 & 24 & 8,555 & 3,695 & 4,432 & 31 & 35 & 54 \\
\hline Western & 34 & 37 & 49 & 21,904 & 14,704 & 27,741 & 122 & 66 & 96 \\
\hline Eastern Interior & 97 & 103 & 109 & 621,783 & 704,334 & 671,323 & 858 & 877 & 968 \\
\hline Southcentral & 13 & 25 & 32 & 1,801 & 2,424 & 4,979 & 26 & 47 & 80 \\
\hline Southwestern & 12 & 11 & 18 & 4,714 & 8,197 & 4,659 & 25 & 18 & 47 \\
\hline Alaska Peninsula ${ }^{c}$ & 1 & 1 & 0 & 3 & 2 & 0 & 2 & 2 & 0 \\
\hline Southeastern $^{\mathrm{d}}$ & 3 & 3 & 6 & 68,173 & 67,396 & 67,523 & 283 & 322 & 343 \\
\hline TOTAL & 178 & 200 & 238 & 726,933 & 800,752 & 780,657 & 1,347 & 1,367 & 1,588 \\
\hline
\end{tabular}

a2009 production includes 720,407 ounces of gold from hardrock mines and 60,250 ounces of gold from placer sources. 'Includes recreation numbers (operators, ounces, employees) and is calculated on the basis of full-year employment.

'Production from this single source is combined with southwestern production for confidentiality purposes.

Includes Greens Creek Mine numbers in all categories, which is a polymetallic producer with a strong gold component.

Table 15. Production for selected Alaska placer gold mines, 2002-2009.

\begin{tabular}{|c|c|c|c|c|c|c|c|c|}
\hline \multicolumn{9}{|c|}{ Number of Mines } \\
\hline Mine Size & 2002 & 2003 & 2004 & 2005 & 2006 & 2007 & 2008 & 2009 \\
\hline Small $^{\mathrm{a}}$ & 43 & 58 & 60 & 50 & 177 & 153 & 169 & 485 \\
\hline Medium ${ }^{b}$ & 4 & 4 & 5 & 20 & 21 & 19 & 24 & 16 \\
\hline Large $^{c}$ & 2 & 2 & 3 & 1 & 3 & 2 & 2 & 2 \\
\hline TOTAL & 49 & 64 & 68 & 71 & 201 & 174 & 195 & 503 \\
\hline \multicolumn{9}{|c|}{ Production in Ounces $^{d}$} \\
\hline Small & 9,931 & 8,124 & 7,621 & 6,783 & 23,343 & 19,755 & 19,601 & 23,916 \\
\hline Medium & 4,739 & 4,976 & 4,504 & 17,822 & 22,144 & 23,366 & 27,298 & 20,680 \\
\hline Large & 7,711 & 10,500 & 15,950 & $-e^{e}$ & 14,895 & 10,728 & 9,860 & 15,654 \\
\hline TOTAL & 22,381 & 23,600 & 28,075 & 24,605 & 60,382 & 53,849 & 56,759 & 60,250 \\
\hline
\end{tabular}

Final 2009 sand and gravel production was reported to be 4.7 million tons of sand and gravel processed by approximately 286 full-time-equivalent employees compared with final 2008 sand and gravel production estimate of 12.46 million tons processed by $277 \mathrm{em}-$ ployees. Preliminary 2009 rock production reports are 1.8 million tons processed by 83 employees compared to final 2009 rock production reports of 2.47 million tons processed by 93 employees. Reporting shortfalls for both sand and gravel production and rock production are noted. Several large rock, sand, and gravel producers declined to contribute non-mandatory information; as a result rock, sand, and gravel estimates are very incomplete and are probably quite low.

The Alaska export value of minerals was $\$ 980$ million for 2009, 15 percent higher than in 2008 at $\$ 853$ million. The total exports include copper-gold concentrates from the Minto Mine in Yukon that were shipped through the terminal in Skagway. See table 18 and figure 18.

Peat production estimates for 2009 are approximately 240,510 cubic yards, processed by seven employees, compared with 2008 production of 83,789 cubic yards processed by seven employees. Significant reporting shortfalls for peat are noted. 
Table 16. Reported sand and gravel production and industry employment in Alaska by region, 2009.

\begin{tabular}{lcrrrr}
\hline Region & $\begin{array}{c}\text { Companies and } \\
\text { agencies reporting }\end{array}$ & Tons & $\begin{array}{c}\text { Estimated unit } \\
\text { value (\$/ton) }\end{array}$ & $\begin{array}{c}\text { Total } \\
\text { value }\end{array}$ & $\begin{array}{c}\text { Estimated number } \\
\text { of employees }\end{array}$ \\
\cline { 2 - 6 } Northern & 23 & $2,039,176$ & $\$ 6.70$ & $\$ 13,662,480$ & 115 \\
Western & 15 & 464,387 & 7.23 & $3,359,541$ & 22 \\
Eastern Interior & 63 & $1,546,183$ & 6.59 & $10,192,040$ & 56 \\
Southcentral & 43 & $2,501,058$ & 4.37 & $10,924,484$ & 66 \\
Southwestern & 4 & 348,973 & 5.94 & $2,073,560$ & 16 \\
Alaska Peninsula & 0 & -- & -- & -- & 0 \\
Southeastern & 13 & 172,260 & 6.70 & $1,154,139$ & 10 \\
TOTAL & $\mathbf{1 6 1}$ & $\mathbf{7 , 0 7 2 , 0 3 7}$ & & $\mathbf{\$ 4 1 , 3 6 6 , 2 4 4}$ & $\mathbf{2 8 6}$ \\
\end{tabular}

${ }^{\mathrm{a}}$ From returned questionnaires, telephone surveys, follow-up fax questionnaires, and e-mails to probable producers, etc. Data were also returned from the Alaska Railroad, Alyeska Pipeline Service Co., DML\&W, USFWS, USBLM, USFS, regional corporations, and others. ${ }^{b}$ Values are based on estimates from producers.

- - = Not reported.

Table 17. Reported rock production and industry employment in Alaska by region, 2009a .

\begin{tabular}{|c|c|c|c|c|c|}
\hline Region & $\begin{array}{c}\text { Companies and } \\
\text { agencies reporting }\end{array}$ & Tons & $\begin{array}{l}\text { Estimated unit } \\
\text { value (\$/ton) }{ }^{\mathrm{c}}\end{array}$ & $\begin{array}{l}\text { Total } \\
\text { value }\end{array}$ & $\begin{array}{c}\text { Estimated number } \\
\text { of employees }\end{array}$ \\
\hline Northern & 9 & 143,109 & $\$ 15.00$ & $\$ 2,146,635$ & 8 \\
\hline Western & 1 & 52,000 & 25.00 & $1,300,000$ & 2 \\
\hline Eastern Interior & 18 & 229,803 & 13.57 & $3,119,545$ & 13 \\
\hline Southcentral & 12 & 188,213 & 18.89 & $3,556,195$ & 9 \\
\hline Southwestern & 16 & 376,160 & 15.00 & $5,642,393$ & 21 \\
\hline Alaska Peninsula & 0 & -- & -- & - - & 0 \\
\hline Southeastern & 10 & 847,805 & 13.53 & $11,469,393$ & 29 \\
\hline TOTAL & 66 & $1,837,090$ & & $\$ 27,234,160$ & 83 \\
\hline
\end{tabular}

${ }^{a}$ Includes shot rock, crushed stone, D-1, riprap, and modest quantities of ornamental stone.

${ }^{b}$ From 15 returned DGGS questionnaires, more than 100 telephone surveys, follow-up fax questionnaires, more than 100 e-mails to probable producers, etc. Data were also returned from the Alaska Railroad, Alyeska Pipeline Service Co., DML\&W, DOT\&PF, USFS, USBLM, USFS, regional corporations, and others.

'Values are based on estimates from producers, from historic records, etc.

- - = Not reported.

\section{NORTHERN REGION}

Northern region estimated production value was $\$ 1,331$ million with an employment of 595 full-timeequivalent positions. Red Dog Mine dominated the production value and employment numbers. Placer gold, sand and gravel, and minor rock production also took place in the region. Production was reported by 22 commercial and two recreational placer mining operations in the Northern region; 23 sand and gravel and eight rock operations reported production.

Approximately 54 full-time-equivalent positions were employed in placer mining, and approximately 4,432 ounces of placer gold were produced. This compares with approximately 20 placer gold mining operations employing approximately 35 full-timeequivalent positions and producing 3,695 ounces of placer gold in 2008.

\section{Red Dog Mine}

Red Dog Mine is 100 percent owned and operated by Teck Resources Ltd. under an agreement with NANA Regional Corp., a Native Alaskan regional corporation. Red Dog Mine is in northwestern Alaska, approximately 100 miles north of Kotzebue and 50 miles inland from the Chukchi Sea, at the southern foothills of the Brooks Range. Red Dog is the world's largest zinc producer, both in terms of reserves and annual zinc production. Lead and zinc concentrates are trucked to the Delong Mountain terminal on the coast for shipping during the summer. Red Dog Mine dominates Alaska's mineral production value, accounting for approximately 54 percent of the total value of Alaska's mineral production in 2009.

The Red Dog deposit comprises a number of sedimentary-hosted exhalative (SEDEX) lead-zinc sulfide deposits hosted in Mississippian- to Pennsylvanian-age 
sedimentary rocks. The ore bodies are lens shaped and occur within structurally controlled (thrust fault) plates. The sulfide mineralization consists of semi-massive to massive sphalerite, pyrite, marcasite, and galena.

The mining method employed is conventional drill and blast open-pit mining. The main pit has an expected life of two years at current rates of production. Total proven and probable reserve estimates, including the Aqqaluk deposit, as of December 31, 2009 are shown in table 19.

Employment at Red Dog Mine complex during 2009 equaled 413 full-time-equivalent employees, a significant ( 13 percent) reduction from the 475 full-timeequivalent employees in 2008. More than 50 percent of the employees are NANA shareholders.

The shipping season at Red Dog Mine is restricted to approximately 100 days per year because of sea ice conditions, and Red Dog Mine's sales are seasonal with the majority of sales in the last five months of each year. Concentrate is stockpiled at the port facility and is typi- cally shipped between July and October. Red Dog's 2009 shipping season began on June 30 and was completed on October 18. The mine shipped 1,124,000 tons of zinc concentrate and 243,000 tons of lead concentrate during the 2009 season. This compares with shipments of 1,014,000 tons of zinc and 272,000 tons of lead concentrate for the 2008 shipping season.

Red Dog set a new annual record for contained metal production in 2009 following a number of site-driven performance improvement initiatives. The project milled $3,729,000$ tons of ore in 2009 with a zinc grade of 20.9 percent and a lead grade of 5.9 percent compared with $3,362,000$ tons milled in 2008 with a zinc grade of 20.1 percent and a lead grade of 6.0 percent. In 2009, zinc recovery was 82.4 percent, and lead recovery was 65.9 percent. See table 20 for complete production information.

The mine produced 642,096 tons of zinc in concentrate and 144,954 tons of lead in concentrate in 2009. In addition, the mine was credited with production of

Table 18. Alaska international mineral exports.

\begin{tabular}{lc}
\hline & $\begin{array}{c}\text { Export value } \\
\text { (millions) }\end{array}$ \\
\cline { 2 - 2 } 1996 & $\$ 249$ \\
1997 & 369 \\
1998 & 317 \\
1999 & 359 \\
2000 & 293 \\
2001 & 329 \\
2002 & 380 \\
2003 & 414 \\
2004 & 505 \\
$2005^{\mathrm{a}}$ & 603 \\
$2006^{\mathrm{a}}$ & 1,196 \\
$2007^{\mathrm{a}}$ & 1,317 \\
$2008^{\mathrm{a}, \mathrm{b}}$ & 853 \\
$2009^{\mathrm{c}}$ & 980 \\
& \\
\hline
\end{tabular}

Source: U.S. Census Bureau, Origin of Movement Series.

${ }^{a}$ Includes mineral/metal ores and concentrates, coal, and unwrought, nonmonetary gold exports.

bIncludes $\$ 103$ million of copper concentrates produced in Yukon Territory by Sherwood Copper/Capstone Mining and shipped through the Skagway Ore Terminal.

'Includes zinc ores and concentrates, lead ores and concentrates, gold, nonmonetary, unwrought; coal; and zirconium ores and concentrates.

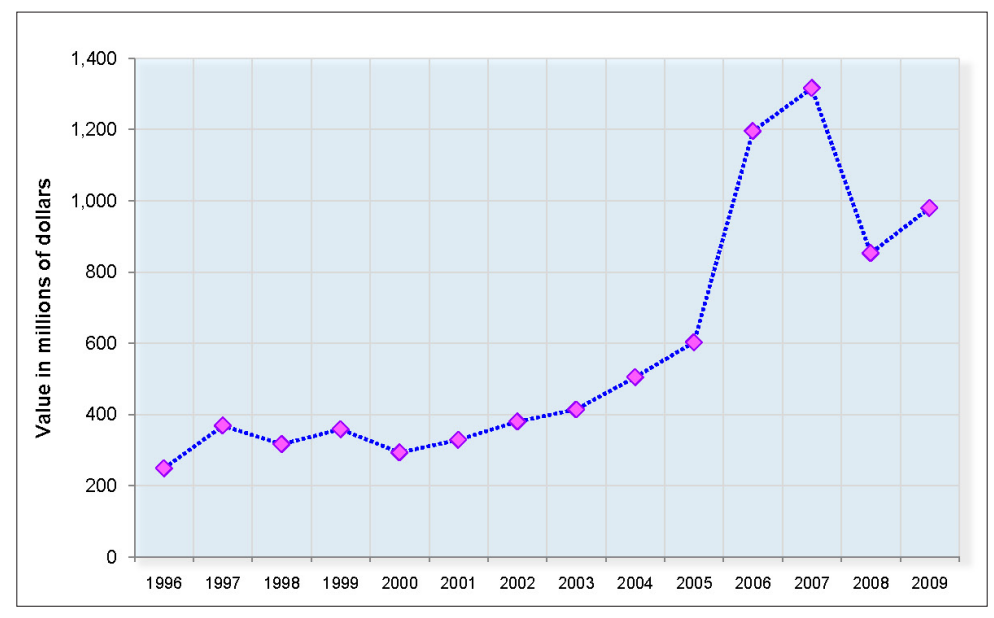

Figure 18. Alaska international mineral exports, 1996-2009.

Table 19. Reserves and resources by category at Red Dog Mine as of December 31, 2009 (Teck Resources Ltd. Annual report).

\begin{tabular}{lllrr}
\hline Class & Metal & Category & $\begin{array}{c}\text { Tons, } \\
\text { millions }\end{array}$ & $\begin{array}{r}\text { Grade, } \\
\text { percent }\end{array}$ \\
\hline \multirow{3}{*}{ Reserves } & & & & \\
& Zinc & Proven & 10.14 & 20.0 \\
& & Probable & 57.52 & 16.6 \\
& Lead & Proven & 10.14 & 5.4 \\
& & Probable & 57.52 & 4.4 \\
Resources & Zinc & Indicated & 6.50 & 20.0 \\
& & Inferred & 34.16 & 11.0 \\
& Lead & Indicated & 6.50 & 6.6 \\
& & Inferred & 34.16 & 4.0
\end{tabular}


Table 20. Red Dog Mine production statistics, 1989-2009a.

\begin{tabular}{|c|c|c|c|c|c|c|c|c|c|}
\hline & \multirow[b]{2}{*}{$\begin{array}{c}\text { Tons } \\
\text { Milled }\end{array}$} & \multicolumn{3}{|c|}{ Ore Grade } & \multirow{2}{*}{$\begin{array}{c}\text { Total Tons } \\
\text { Concentrate } \\
\text { Produced }^{\mathbf{b}}\end{array}$} & \multirow{2}{*}{$\begin{array}{c}\text { Contained } \\
\text { Tons } \\
\text { Zinc } \\
\end{array}$} & \multirow{2}{*}{$\begin{array}{c}\text { Contained } \\
\text { Tons } \\
\text { Lead } \\
\end{array}$} & \multirow{2}{*}{$\begin{array}{c}\text { Million } \\
\text { Ounces } \\
\text { Silver }^{c}\end{array}$} & \multirow[b]{2}{*}{ Employees } \\
\hline & & $\begin{array}{l}\text { Zinc } \\
(\%)\end{array}$ & $\begin{array}{r}\text { Lead } \\
(\%)\end{array}$ & $\begin{array}{l}\text { Silver } \\
\text { (oz/ton) }\end{array}$ & & & & & \\
\hline 1989 & 33,300 & 20.4 & 7.6 & 3.6 & 8,532 & -- & -- & - - & 228 \\
\hline 1990 & 996,700 & 26.5 & 8.5 & 3.6 & 443,600 & 191,981 & 31,187 & 1.60 & 350 \\
\hline 1991 & $1,599,300$ & 22.5 & 6.6 & 2.8 & 521,400 & 234,510 & 43,815 & 1.46 & 331 \\
\hline 1992 & $1,582,000$ & 19.9 & 6.0 & 2.9 & 474,900 & 231,363 & 15,960 & 1.38 & 349 \\
\hline 1993 & $1,874,600$ & 18.4 & 5.7 & 2.8 & 539,800 & 255,149 & 24,788 & 1.51 & 376 \\
\hline 1994 & $2,339,500$ & 18.8 & 5.7 & 2.8 & 658,000 & 328,160 & 32,775 & 1.84 & 391 \\
\hline 1995 & $2,485,900$ & 19.0 & 5.8 & 2.8 & 753,600 & 358,676 & 55,715 & 3.62 & 397 \\
\hline 1996 & $2,312,600$ & 18.7 & 5.0 & 2.8 & 765,300 & 357,680 & 65,886 & 4.30 & 417 \\
\hline 1997 & $2,127,000$ & 20.3 & 5.2 & 2.9 & 799,400 & 373,097 & 69,284 & 4.27 & 479 \\
\hline 1998 & $2,752,587$ & 21.4 & 5.2 & 2.7 & $1,015,773$ & 490,461 & 80,193 & 5.20 & 466 \\
\hline 1999 & $3,282,788$ & 21.3 & 5.2 & 2.7 & $1,207,160$ & 574,111 & 97,756 & 6.21 & 539 \\
\hline 2000 & $3,365,508$ & 21.0 & 4.7 & 2.5 & $1,211,539$ & 585,030 & 91,557 & 5.84 & 536 \\
\hline 2001 & $3,560,430$ & 19.8 & 5.0 & 2.5 & $1,215,837$ & 570,980 & 105,000 & 5.90 & 559 \\
\hline 2002 & $3,489,600$ & 21.1 & 5.4 & 2.7 & $1,366,480$ & 637,800 & 118,880 & 6.75 & 560 \\
\hline 2003 & $3,476,689$ & 21.7 & 6.2 & 3.1 & $1,410,892$ & 638,569 & 137,679 & 7.70 & 388 \\
\hline 2004 & $3,249,613$ & 22.0 & 6.0 & 3.0 & $1,337,545$ & 610,900 & 128,970 & 7.22 & 508 \\
\hline 2005 & $3,402,831$ & 21.7 & 5.6 & 3.0 & $1,330,717$ & 626,112 & 112,766 & 1.97 & 449 \\
\hline 2006 & $3,569,280$ & 20.6 & 6.1 & 3.0 & $1,378,384$ & 614,538 & 136,135 & 7.62 & 457 \\
\hline 2007 & $3,726,910$ & 20.2 & 6.1 & 3.1 & $1,428,014$ & 633,511 & 146,152 & 11.55 & 459 \\
\hline 2008 & $3,306,934$ & 20.1 & 6.0 & 3.1 & $1,273,885$ & 567,911 & 135,143 & 7.50 & 475 \\
\hline 2009 & $3,729,119$ & 20.9 & 5.9 & 3.1 & $1,445,870$ & 642,096 & 144,954 & 8.12 & 413 \\
\hline
\end{tabular}

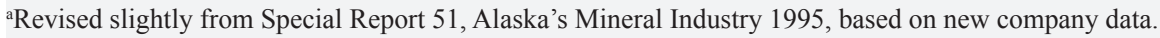

${ }^{\text {b} T o t a l s ~ f o r ~ y e a r s ~} 1990$ through 1995 include bulk concentrate.

'Estimate calculated at 56 ounces per ton of lead metal produced to from 1990 to 2004 and 2006, as reported credit for 2005, net of treatment charges, calculated at $3.1 \mathrm{oz} /$ ton of ore for 2007 .

- - = No concentrate produced.

$8,114,400$ ounces of silver in 2009. In 2008, the mine produced 567,911 tons of zinc in concentrate, and 135,144 tons of lead in concentrate, and was credited with an estimated 7,498,024 ounces of silver.

Teck expects 2010 production to be approximately 606,000 tons of zinc in concentrate and 105,000 tons of lead contained in concentrate. Production in 2010 is forecast to be lower than in 2009 due to the lower ore grades expected in the bottom of the main pit.

Red Dog's operating profit before depreciation and amortization was $\$ 414$ million in 2009, compared with $\$ 225$ million in 2008. In accordance with the operating agreement governing Red Dog Mine, the royalty to NANA Regional Corporation Inc., Teck's Alaska Native Regional Corporation partner, is 25 percent of net proceeds of production. The NANA royalty charge in 2009 was $\$ 128$ million compared with $\$ 92$ million in 2008 . The net proceeds royalty will increase by 5 percent every fifth year to a maximum of 50 percent. The increase to 30 percent of net proceeds of production will occur in 2012. NANA shares approximately 62 percent of the royalty with other Alaska Native Regional Corporations pursuant to section 7(i) of the Alaskan Native Claims Settlement Act.

\section{WESTERN REGION}

Forty-nine placer operations, including eight recreational in nature, reported production in the region for 2009, compared to 36 and five, respectively, for 2008. Reported production for 2009 was 27,741 ounces of gold, contrasted with a production of 14,704 ounces of gold in 2008. Placer gold employment in 2009 was estimated to be 96 full-time-equivalent positions, compared with 66 for 2008. Reporting shortfalls are noted with most of the commercial recreational services.

Sand and gravel production in the western region in 2009 was reported to be 464,387 tons from 15 operations compared to 638,139 tons from 15 operations in 2008. Employment was estimated to be 22 full-time-equivalent jobs in 2009 compared to 14 full-time-equivalent jobs in 2008.

Rock production was reported at 52,000 tons from one operation in 2008 compared with a reported 125,088 tons from three operations in 2008. Full-time equivalent jobs during 2009 were estimated to be two, whereas full-time-equivalent jobs during 2008 were estimated at six. The apparent decline in sand and gravel and rock production in 2009 is likely due to a lack of reporting. 


\section{EASTERN INTERIOR REGION}

As in previous years, the eastern interior region had the largest number of mining operations region during 2009 compared to other Alaskan regions. Pogo Mine was the largest gold producer in the region, followed by Fort Knox Mine. Total gold production from the region was 671,323 ounces in 2009 compared to 704,334 ounces during 2008. Lode gold (hardrock) production of gold amounted to 653,068 ounces, compared to 676,724 in 2008.

Placer gold production from 107 operations amounted to 18,255 ounces compared to 27,610 ounces during 2008. Nine of the 2009 operations were considered recreational in size. Employment estimates for placer operations is 136 persons, compared with an estimated 139 persons who were employed in full-time-equivalent placer production in the region in 2008 .

Industrial minerals continued to be an important sector in the interior region during 2009. Sand and gravel production amounted to 1.55 million tons from 63 operations in 2009 compared with 2.5 million tons from 48 different operations in 2008. Estimated employment for these operations was approximately 56 full-time-equivalent positions in 2009 compared with 82 positions in 2008. Rock production amounted to 229,803 tons from 18 operations and created approximately 13 full-time-equivalent positions compared with 120,474 tons, three operations, and approximately seven fulltime-equivalent positions in 2008. Note that there is a poor reporting rate in the sand and gravel category, so estimates are probably low.
Peat production was reported to be 33,265 bank cubic yards for 2009, an approximately 25 percent decrease from a reported 44,345 bank cubic yards for 2008 . The authors surmise there are also shortfalls in the reporting of this commodity. Employment for the coal and peat industry was estimated to be 117 full-time-equivalent positions in both 2009 and 2008.

\section{Fort Knox Mine}

Fort Knox Mine, operated by Fairbanks Gold Mining Inc. (FGMI), a wholly owned subsidiary of Kinross Gold Corp., produced 263,260 ounces of gold in 2009, a 20 percent decrease from the 329,105 ounces produced in 2008.

Fort Knox mined 27.59 million tons in 2009 compared with 46.3 million tons in 2008 (table 21). Geotechnical issues at the East Wall caused fewer tons of ore to be mined in 2009 compared with 2008. The mine plan was modified to improve stability in the pit wall.

Mill throughput in 2009 was 17,884,000 tons compared to 2008 mill throughput of $15,110,000$ tons, with an average 82.9 percent recovery in 2009 compared with 81.8 percent in 2008. Mill throughput was increased following the start of the Walter Creek heap leach facility. Approximately 3.75 million tons of ore had been stacked at the new Fort Knox heap leach as of the end of the fourth quarter 2009. According to Kinross, the leaching was progressing well.

According to Kinross, gold production in 2009 was lower than 2008 primarily due to lower grades, which more than offset the higher tons processed and the slightly higher recovery.

Table 21. Fort Knox Mine production statistics, 1996-2009.

\begin{tabular}{|c|c|c|c|c|c|c|c|c|}
\hline & \multicolumn{3}{|c|}{ Tons Mined (ore + waste) } & \multicolumn{3}{|c|}{ Tons milled (ore) } & \multirow{2}{*}{$\begin{array}{l}\text { Ounces } \\
\text { Gold } \\
\text { Produced }\end{array}$} & \multirow{2}{*}{$\begin{array}{c}\text { Employ- } \\
\text { ees }\end{array}$} \\
\hline & Fort Knox & True North ${ }^{a}$ & Total & Fort Knox & True North ${ }^{a}$ & Total & & \\
\hline 1996 & $16,684,000$ & NA & $16,684,000$ & 769,700 & NA & 769,700 & 16,085 & 243 \\
\hline 1997 & $32,380,000$ & NA & $32,380,000$ & $12,163,151$ & NA & $12,163,151$ & 366,223 & 249 \\
\hline 1998 & $33,294,000$ & NA & $33,294,000$ & $13,741,610$ & NA & $13,741,610$ & 365,320 & 245 \\
\hline 1999 & $30,350,000$ & NA & $30,350,000$ & $13,819,010$ & NA & $13,819,010$ & 351,120 & 253 \\
\hline 2000 & $35,600,000$ & NA & $35,600,000$ & $15,000,000$ & NA & $15,000,000$ & 362,929 & 253 \\
\hline 2001 & $25,957,900$ & $8,448,400$ & $34,406,300$ & $13,282,614$ & $2,377,386$ & $15,660,000$ & 411,220 & 360 \\
\hline 2002 & $24,583,500$ & $11,461,000$ & $36,044,500$ & $11,887,200$ & $3,371,800$ & $15,259,000$ & 410,519 & 360 \\
\hline 2003 & $30,597,940$ & $12,707,100$ & $43,305,040$ & $11,473,000$ & $3,611,682$ & $15,084,682$ & 391,831 & 316 \\
\hline 2004 & $44,187,000$ & $3,763,000$ & $47,950,000$ & $12,917,966$ & $1,675,854$ & $14,593,820$ & 338,334 & 427 \\
\hline 2005 & $63,248,000$ & - & $63,248,000$ & $14,384,842$ & - & $14,384,842$ & 329,320 & 411 \\
\hline 2006 & $51,070,000$ & - - & $51,070,000$ & $14,839,297$ & - & $14,839,297$ & 333,383 & 406 \\
\hline 2007 & $45,940,000$ & - & $45,940,000$ & $14,021,400$ & - & $14,021,400$ & 338,459 & 399 \\
\hline 2008 & $46,300,000$ & - & $46,300,000$ & $15,110,000$ & - & $15,110,000$ & 329,105 & 449 \\
\hline 2009 & $27,585,000$ & - & $27,585,000$ & $17,884,000$ & - & $17,884,000$ & 263,260 & 500 \\
\hline
\end{tabular}


Production focused on higher grades (although a harder-to-grind portion of the ore body) and was supplemented by lower-grade stockpile ores. The grade mined was lower in 2009 because of three factors: (1) the processing of lower-grade stockpile ore, (2) the mine plan called for mining an area of the pit with a lower grade than the area mined in 2008, and (3) the inclusion of 3.7 million tons added to the heap leach.

Fort Knox paid a royalty of $\$ 832,676$ to the Alaska Mental Health Trust Land Office for 2009 production from Trust lands.

As of December 2009, FGMI reached 2.82 million man hours and three years without a lost-time incident. Fort Knox employees worked approximately 1,041,376 man hours in 2009. The milling and mining operations at Fort Knox continue to operate 24 hours a day, 365 days a year. As of the end of 2009, FGMI employed 467 full-time-equivalent personnel, a decrease from the yearly average of 500 employees.

In 2009, Fort Knox and the Alaska Department of Fish and Game were recipients of the Alaska Conservation Alliance and the Resource Development Council's Second Annual Tileston Award for their work in restoring fish habitat and Arctic grayling to Fish Creek.

Total proven and probable reserve estimates for Fort Knox Mine, as of December 31, 2009, are shown in table 22.

\section{Pogo Mine}

Pogo Mine, an underground gold mine about 90 miles southeast of Fairbanks and 38 miles northeast of Delta Junction, produced 389,808 ounces of gold in 2009 compared with 347,219 ounces in 2008 , a 12 percent increase (table 23). The mine was a joint venture

Table 22. Reserves at Fort Knox as of December 31, 2009.

\begin{tabular}{lccc}
\hline & & & \\
& Tons & Grade & $\begin{array}{c}\text { Gold } \\
\text { Ounces }\end{array}$ \\
\cline { 2 - 4 } Proven & $166,202,000$ & 0.0113 & $1,879,000$ \\
Probable & $112,622,000$ & 0.0161 & $1,813,000$ \\
\cline { 2 - 4 } Total & $\mathbf{2 7 8 , 8 2 4 , 0 0 0}$ & $\mathbf{0 . 0 1 3 2}$ & $\mathbf{3 , 6 9 2 , 0 0 0}$
\end{tabular}

between Sumitomo Metal Mining Co. Ltd. (51 percent), Sumitomo Corp. (9 percent), and Teck Resources Ltd. (40 percent) and was operated by Teck Pogo Inc. On July 7, 2009, Teck Resources Ltd. announced the \$245 million sale of its 40 percent ownership to affiliates of Sumitomo Metal Mining Co. Ltd. and Sumitomo Corp. Sumitomo Metal Mining Pogo LLC (SMM Pogo) operates the mine on behalf of owners Sumitomo Metal Mining Co. Ltd. (85 percent) and Sumitomo Corp. (15 percent).

Pogo Mine excavated 944,823 tons of material in 2009. According to SMM Pogo, the milling focus in 2009 was continuous improvement and optimization of the milling process. The mill processed 2,550 tons per day in 2009 for a total of 930,836 tons for the year. The budgeted production was 900,527 tons. Gold produced was 389,808 ounces, exceeding the 357,894 ounces budgeted by 9 percent. Pogo poured its one millionth ounce of gold - a milestone - on October 6, 2009.

Employment at year end was 299 full-time-equivalent employees with an additional 101 contract employees in housekeeping and underground development.

Mining in 2010 is budgeted for 920,414 tons of ore and 21,000 feet of lateral development.

Pogo was one of three mines that supplied a total of 4.52 pounds of gold for the gold medals being presented at the 2010 Winter Olympics in Vancouver. The others were the Hemlo mine in Ontario and the Trail smelter in British Columbia.

Pogo Mine's proven gold reserves are 2,451,440 tons at 0.445 ounces of gold per ton; probable reserves are $4,133,797$ tons at 0.420 ounces of gold per ton.

\section{Usibelli CoAl Mine}

Usibelli Coal Mine Inc. continued production of subbituminous coal from its Two Bull Ridge site near Healy with an output of $1,861,714$ tons of coal in 2009, an increase of 21 percent over the 1,538,000 tons of coal mined in 2008. Of the coal produced at Usibelli in 2009, 975,578 tons ( 52 percent) were consumed in Alaska; the balance was shipped to South Korea and several other Pacific Rim destinations. Six power plants in interior Alaska utilize approximately 900,000 tons annually.

Table 23. Pogo Mine production statistics, 2006-2009

\begin{tabular}{lcccccc}
\hline & $\begin{array}{c}\text { Tons Ore } \\
\text { Mined }\end{array}$ & $\begin{array}{c}\text { Tons Ore } \\
\text { Milled }\end{array}$ & $\begin{array}{c}\text { Ounces of } \\
\text { Gold Recovered }\end{array}$ & $\begin{array}{c}\text { Head Grade } \\
\text { Recovery, \% }\end{array}$ & $\begin{array}{c}\text { Gold } \\
\text { oz/ton }\end{array}$ & Employees \\
\hline 2006 & 447,129 & 338,000 & 113,364 & 85.0 & 0.395 & 477 \\
2007 & 715,665 & 715,400 & 259,820 & 84.4 & 0.430 & 339 \\
2008 & 882,400 & 818,237 & 347,219 & 83.8 & 0.506 & 285 \\
2009 & 944,823 & 930,836 & 389,808 & 88.2 & 0.475 & 272 \\
\hline
\end{tabular}

Includes contractor employees; calculated as 11 hour days, 260 employee-days per year. 
Permitted reserves at Usibelli total 30.6 million tons. According to Usibelli's website, the mine currently has a work force of about 95 full-time-equivalent employees and operates year-round.

\section{SOUTHCENTRAL REGION}

Rock, sand, gravel, and peat (topsoil) continue to be the most valuable commodities produced in this region. The southcentral region had 43 sand and gravel operations in 2009, the same number of operations recorded for 2008. Reported sand and gravel production was down by 56 percent from the previous year's levels and amounted to 2.5 million tons, compared to 5.74 million tons in 2008. The apparent decrease is probably mainly due to a lack of response from producers. Sand and gravel provided 37 percent fewer, or 66 full-time-equivalent jobs, compared to 104 jobs in 2008. Rock production in the southcentral region in 2009 was estimated to be 188,213 tons, reported by 12 operations; employment was estimated at nine full-time-equivalent persons in 2009. This compares to rock production of 404,897 tons and 23 full-time positions in 2008. Reported peat production in 2009 totaled an estimated 37,900 bank cubic yards compared to 39,444 bank cubic yards in 2008. Only one full-time-equivalent position was estimated for peat production in 2009, the same as in 2008 . Reporting shortfalls are thought to be very significant and actual production could be more than 50 percent above reported numbers.

Placer gold production in the southcentral region in 2009 was estimated to be 4,979 ounces. Placer gold production reported for this region during 2008 was 2,424 ounces. Placer gold production was reported by 32 operators in 2009 compared to 25 in 2008 . In both 2009 and 2008, six of the operators were recreational in size. Total full-time-equivalent employment in 2009 was estimated at 80 positions compared to 47 during 2008.

Diamond Gold Corp. produced 30,000 carats of rough jelly and potch opal from the Sable-Kahiltna Mine. Production methods included a backhoe washplant, hand picking, and sorting rough gemstones.

\section{SOUTHWESTERN REGION}

Placer gold production in the southwestern region amounted to 4,659 ounces in 2009 compared to 8,197 ounces in 2008, a drop of 43 percent. Calculated fulltime-equivalent employment was 47 in 2009, a rise of 160 percent compared to 18 persons in 2008. Eighteen operators reported production in 2009, compared to 11 operators in 2008 . As in 2008 , one of the southwestern operations was considered recreational in size.

Rock, sand, and gravel production was reported from the southwestern region in both 2009 and 2008. Sand and gravel production in 2009 amounted to 348,973 tons and provided 16 full-time-equivalent jobs, compared to
551,700 tons and 12 full-time-equivalent jobs in 2008 . Rock production in 2009 amounted to 376,160 tons and provided 21 full-time-equivalent jobs, compared with 205,200 tons and 12 full-time-equivalent jobs in 2008 . Four sand and gravel and 16 rock operations provided reports in 2009, compared with nine sand and gravel and four rock operations in 2008. Reporting shortages are noted, particularly in the sand and gravel sector.

\section{ALASKA PENINSULA REGION}

No production for any commodity was noted in the Alaska Peninsula region in 2009. One recreational gold operation producing 2.3 ounces of gold was reported in 2008 , but no production was reported for any commodity in 2006 or 2007. The limited production reported from this area is believed to be due to reporting shortfalls rather than to a lack of production.

\section{SOUTHEASTERN REGION}

The southeastern region reported polymetallic, rock, sand and gravel, and placer gold production for 2009 . Total employment in minerals industry production for the region was 382 full-time-equivalent positions in 2009, compared to approximately 369 in 2008.

Five placer gold operations reported production for 2009 , with a yield of 223 ounces of gold. Calculated employment was 22 full-time-equivalent positions. This compares to two placer gold operations that reported production for 2008 and yielded 127 ounces of gold with five full-time-equivalent positions.

Rock, sand, and gravel operations in 2009 in the southeastern region produced 172,260 tons of sand and gravel and 847,805 tons of rock; 13 sand and gravel and ten rock producers reported. This compares to rock, sand, and gravel operations in 2008 in the southeastern region that produced 151,457 tons of sand and gravel and 1,592,797 tons of rock with 14 sand and gravel and 14 rock producers reporting. This area reported approximately ten full-time-equivalent employees in the sand and gravel sector in 2009 and approximately 29 full-time-equivalent employees in the rock sector. This compares to three full-time-equivalent sand and gravel and 44 full-time-equivalent rock employees in 2008. The southeastern and western regions are the only areas with skewed sand and gravel to rock production ratio; all the other regions have higher sand and gravel to rock production ratio. Serious shortfalls in reporting are indicated.

\section{Greens Creek Mine}

Greens Creek Mine is a polymetallic, volcanogenic massive sulfide deposit (silver-zinc-lead-gold-copper) and is considered the fifth-largest primary silver producer in the world. It produces a silver-gold doré and sulfide concentrates containing zinc and lead. Hecla Mining Co. 
owned a 29.7 percent interest in Greens Creek through April 16, 2008, and a 100 percent interest thereafter. The mine has produced a total of about 151.2 million ounces of silver and 1.12 million ounces of gold since 1989. Probable ore reserves on December 31, 2009, contained 100.97 million ounces of silver, 847,400 ounces of gold, 852,900 tons of zinc, and 303,300 tons of lead, with a mine life projected to 2019 (table 24).
Production at Greens Creek Mine was higher in 2009 than in 2008, a result of increased mill throughput. Mill throughput at Greens Creek in 2009 averaged 2,167 tons per day in 2009,8 percent more than in 2008. Mill recovery totaled approximately 72 percent silver, 79 percent zinc, 69 percent lead, and 64 percent gold in 2009. According to Hecla, the mine produced 7.5 million ounces of silver in 2009 , at an average total

Table 24. Reserves and resources by category at Greens Creek Mine as of December 31, 2009 (Hecla Mining Co. 2009 annual report).

\begin{tabular}{lrrrrr}
\hline & & \multicolumn{4}{c}{ Grade } \\
\cline { 3 - 6 } Class & Tons & $\begin{array}{c}\text { Silver } \\
\text { oz/ton }\end{array}$ & $\begin{array}{c}\text { Gold } \\
\text { oz/ton }\end{array}$ & $\begin{array}{c}\text { Lead } \\
\text { percent }\end{array}$ & $\begin{array}{c}\text { Zinc } \\
\text { percent }\end{array}$ \\
\hline Probable Reserve & $8,314,700$ & 12.1 & 0.102 & 3.6 & 10.3 \\
Mineralized Material & 789,800 & 4.1 & 0.063 & 2.0 & 4.6 \\
Other Resources & $2,412,000$ & 11.5 & 0.092 & 2.7 & 6.8 \\
\hline TOTAL & $\mathbf{1 1 , 5 1 6 , 5 0 0}$ & $\mathbf{1 1 . 4}$ & $\mathbf{0 . 0 9 7}$ & $\mathbf{3 . 3}$ & $\mathbf{9 . 2}$
\end{tabular}

Table 25. Greens Creek Mine production statistics, 1989-2009.

\begin{tabular}{|c|c|c|c|c|c|c|c|c|}
\hline & \multirow[b]{2}{*}{$\begin{array}{c}\text { Tons } \\
\text { Milled }\end{array}$} & \multirow[b]{2}{*}{$\begin{array}{c}\text { Tons } \\
\text { Concentrate }\end{array}$} & \multicolumn{5}{|c|}{ Contained Metal } & \multirow[b]{2}{*}{ Employees } \\
\hline & & & $\begin{array}{l}\text { Tons } \\
\text { Zinc }\end{array}$ & $\begin{array}{l}\text { Tons } \\
\text { Lead }\end{array}$ & $\begin{array}{c}\text { Tons } \\
\text { Copper }^{\mathrm{a}}\end{array}$ & $\begin{array}{c}\text { Ounces } \\
\text { Gold }\end{array}$ & $\begin{array}{l}\text { Ounces } \\
\text { Silver }\end{array}$ & \\
\hline 1989 & 264,600 & - & 187,007 & 9,585 & - & 23,530 & $5,166,591$ & 235 \\
\hline 1990 & 382,574 & - & 37,000 & 16,728 & - & 38,103 & $7,636,501$ & 265 \\
\hline 1991 & 380,000 & - & 41,850 & 16,900 & - & 37,000 & $7,600,000$ & 238 \\
\hline 1992 & 365,000 & 113,827 & 40,500 & 16,500 & - & 32,400 & $7,100,000$ & 217 \\
\hline $1993^{b}$ & 77,780 & - & 9,500 & 3,515 & - & 7,350 & $1,721,878$ & 217 \\
\hline $1994^{\mathrm{c}}$ & - & - & - & - - & - - & - - & - & - - \\
\hline $1995^{\mathrm{c}}$ & - & - & - & - & - & - & - & -- \\
\hline $1996^{\mathrm{b}}$ & 135,000 & 43,000 & 9,100 & 4,200 & 193 & 7,480 & $2,476,000$ & 265 \\
\hline 1997 & 493,000 & - & 46,000 & 19,000 & 1,300 & 56,000 & $9,700,000$ & 275 \\
\hline 1998 & 540,000 & - & 58,900 & 22,700 & 1,300 & 60,572 & $9,500,000$ & 275 \\
\hline 1999 & 578,358 & - & 68,527 & 25,503 & 1,400 & 80,060 & $10,261,835$ & 275 \\
\hline 2000 & 619,438 & - & 84,082 & 31,677 & 1,400 & 128,709 & $12,424,093$ & 275 \\
\hline 2001 & 658,000 & - - & 63,903 & 22,385 & 1,400 & 87,583 & $10,900,000$ & 275 \\
\hline 2002 & 733,507 & 217,200 & 80,306 & 27,582 & 1,600 & 102,694 & $10,913,183$ & 262 \\
\hline 2003 & 781,200 & - & 76,200 & 24,800 & - - & 99,000 & $11,707,000$ & 295 \\
\hline 2004 & 805,789 & - - & 69,115 & 21,826 & - & 86,000 & $9,707,000$ & 265 \\
\hline 2005 & 717,600 & - & 58,350 & 18,600 & - & 72,800 & $9,700,000$ & $265^{\mathrm{d}}$ \\
\hline 2006 & 732,176 & - - & 59,429 & 20,992 & - & 62,935 & $8,865,818$ & $245^{\mathrm{e}}$ \\
\hline 2007 & 732,227 & -- & 62,603 & 21,029 & - & 68,006 & $8,646,825$ & $276^{\mathrm{f}}$ \\
\hline 2008 & 734,910 & -- & 58,224 & 18,562 & - - & 67,269 & $7,145,711$ & $336^{g}$ \\
\hline 2009 & 790,871 & -- & 70,379 & 22,253 & - & 67,278 & $7,459,170$ & $321^{\mathrm{h}}$ \\
\hline
\end{tabular}

${ }^{a}$ No copper credits in 1989-1993 and 2003-2009.

bPartial-year production.

'No production in 1994 and 1995 due to mine closure.

${ }^{\mathrm{d}}$ Fifteen of these employees were assigned to development effort.

'Fifty employees were assigned to development and reported in that section's employment.

fForty-five employees were assigned to development and reported in that section's employment.

'Nineteen employees were assigned to development and reported in that section's employment.

- - = Not reported.

hEighty-five employees were assigned to development and reported in that sector's employment. 
cash cost per ounce of $\$ 0.35$, compared to a pro forma production of 7.1 million ounces of silver at an average total cash cost per ounce of $\$ 3.29$ in 2008. Hecla attributes the decrease in cash costs in 2009 to the result of increased mill throughput, increased availability and use of hydroelectric power, and lower prices for some consumable products, primarily diesel fuel.

Greens Creek milled 790,871 tons of ore in 2009,
32 percent more than the 598,931 tons milled in 2008 (table 25). In 2009, the mine also produced 67,278 ounces of gold, 70,379 tons of zinc, and 22,253 tons of lead. This compares to 2008 production of 67,269 ounces of gold, 58,224 tons of zinc, and 18,562 tons of lead.

Greens Creek manpower numbers for 2009 were 321 persons assigned to production and 85 working on development, for a total of 406 .

\section{RECREATIONAL MINING}

Interest in recreational mining has flourished with improved gold prices. Production quantities are not believed to be large, and exact numbers are extremely difficult to obtain. The identity of recreational miners is not sought from individuals and reporting is believed to be a small proportion of the actual number of miners. Returns are sought from commercial ventures, but returns are meager. Production numbers from this sector of the industry are reported in the placer gold production in tables 14 and 15 and are estimated to amount to 367 ounces for 2009 compared to 368 ounces in 2008. Employment numbers reported here are educated guesses, and they include estimates of commercial enterprise employees, miner time at the sites, and time involved by unorganized recreational miners in pursuit of the activity. The indicated full-time-equivalent jobs for 2009 are estimated at 36 throughout the state, compared with 30 in 2008 . These numbers are probably low, especially with respect to commercial enterprise employees and time.

Steve Herschback, of Alaska Mining and Diving, has provided an informative website to list recreational mining opportunities: www.akmining.com/mine/recsites.htm. At least ten commercial ventures that provide recreational mining opportunities are included on the list and in Appendix E. The ventures provide the right to mine along with varying degrees of services and facilities depending on the desires of the prospective miner, which in turn is driven by the remoteness of and access to the site. Charges for mining are moderate to high depending on the location and services provided. The website also lists other opportunities available to the recreational miner.

\section{DRILLING}

Drilling was conducted during all phases of mining (exploration, development, and production) on various projects across Alaska during the year. Table 26 lists companies with a significant drilling program in Alaska during 2009, and tables 27 and 28 summarize drilling activity in the state during 2009 by region and type of drilling. Drilling totals for 2009 are 403,275 feet of core drilling, 260,059 feet of reverse-circulation drilling, and
1,244 feet of placer churn/auger drilling. Placer churn/ auger drilling appears to be under-reported, but yearly total footage for placer operations has varied widely over the past decade. About 70 percent of the 2009 drilling footage was from exploration and development projects in the eastern interior region of Alaska and 13 percent of the drilling footage for the year was from exploration and development projects in southeastern Alaska. The

Table 26. Companies reporting significant drilling programs in Alaska, 2009.

Bravo Venture Group Inc.

Caribou Copper Resources Ltd.

Coeur Inc.

Constantine Metal Resources Ltd.

Donlin Creek JV (Barrick Gold Corp. and NovaGold Resources Inc.)

Full Metal Minerals Ltd.

Geohedral LLC

Hecla Mining Co.

International Tower Hill Mines Ltd. (Talon Gold)

Kinross Gold Corp. (Fairbanks Gold Mining Inc.)

Kiska Metals Corp.

New Gold Inc.
Niblack Mining Corp./CBR GoldCorp./Heatherdale Resources Ltd.

NovaGold Resources Inc.

Pathfinder Mineral Services

Pebble Limited Partnership (Northern Dynasty Minerals Ltd. and Anglo American PLC)

Pure Nickel Inc.

Royal Pretoria

Silverado Gold Mines Ltd.

Sumitomo Metal Mining Pogo LLC

TintinaGold Resources Inc.

Ucore Uranium Inc. (Rare Earth One)

Usibelli Coal Mine Inc. 
2009 drilling footage decreased 43 percent from the 2008 value, but was less than 4 percent lower than the average drilling total between 2000 and 2008. Total drilling footage is expected to increase in 2010 with improving economic conditions.
Information about significant drilling programs in Alaska during 2009 is summarized in the exploration and development sections of this report. The Livengood project operated by International Tower Hill Mines Ltd. had the largest drill program in 2009 , with more than 211,000 feet of reverse-circulation and core drilling.

Table 27. Drilling footage by region in Alaska, 2009.

\begin{tabular}{|c|c|c|c|c|c|c|c|c|}
\hline Type of drilling & Northern & Western & $\begin{array}{l}\text { Eastern } \\
\text { Interior }\end{array}$ & $\begin{array}{l}\text { South- } \\
\text { central }\end{array}$ & $\begin{array}{l}\text { South- } \\
\text { western }\end{array}$ & $\begin{array}{l}\text { South- } \\
\text { eastern }\end{array}$ & $\begin{array}{c}\text { Alaska } \\
\text { Peninsula }\end{array}$ & Total \\
\hline Placer subtotal & 160 & 50 & 610 & 200 & 224 & -- & - & 1,244 \\
\hline Coal subtotal & - & -- & - & - - & -- & -- & - & $0^{\mathrm{a}}$ \\
\hline Hardrock core & 4,994 & 18,720 & 210,767 & 34,698 & 42,355 & 91,741 & - & 403,275 \\
\hline Hardrock rotary & - & 7,519 & 251,440 & 600 & 500 & - - & - - & 260,059 \\
\hline Hardrock subtotal & 4,994 & 26,239 & 462,207 & 35,298 & 42,855 & 91,741 & - & 663,334 \\
\hline TOTAL (feet) & 5,154 & 26,289 & 462,817 & 35,498 & 43,079 & 91,741 & -- & 664,578 \\
\hline
\end{tabular}

- - = Not reported.

Drill footages do not include sand and gravel drilling.

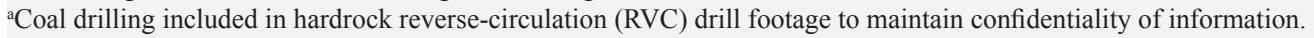

Table 28. Drilling footage reported in Alaska, 1982-2009.

\begin{tabular}{|c|c|c|c|c|c|c|c|c|}
\hline Year & $\begin{array}{c}\text { Placer } \\
\text { Exploration }\end{array}$ & $\begin{array}{c}\text { Placer } \\
\text { Thawing }\end{array}$ & $\begin{array}{c}\text { TOTAL } \\
\text { PLACER }\end{array}$ & $\begin{array}{l}\text { TOTAL } \\
\text { COAL }\end{array}$ & $\begin{array}{c}\text { Hardrock } \\
\text { Core }^{\mathrm{a}}\end{array}$ & $\begin{array}{c}\text { Hardrock } \\
\text { Rotary }^{\mathrm{a}}\end{array}$ & $\begin{array}{c}\text { TOTAL } \\
\text { HARDROCK } \\
\end{array}$ & $\begin{array}{c}\text { TOTAL } \\
\text { FEET }\end{array}$ \\
\hline 1982 & 30,000 & 94,000 & 124,000 & 80,000 & - & - & 200,000 & 404,000 \\
\hline 1983 & 23,000 & 30,000 & 53,000 & 12,000 & - - & -- & 180,500 & 245,500 \\
\hline 1984 & 31,000 & 98,000 & 129,000 & 25,700 & - - & -- & 176,000 & 330,700 \\
\hline 1985 & 46,000 & 34,000 & 80,000 & 8,700 & - - & - - & 131,700 & 220,400 \\
\hline 1986 & 32,400 & 227,000 & 259,400 & 28,800 & - - & - & 50,200 & 338,400 \\
\hline 1987 & 50,250 & 130,000 & 180,250 & 19,900 & 95,600 & 19,500 & 115,100 & 315,250 \\
\hline 1988 & 152,000 & 300,000 & 452,000 & 26,150 & 223,630 & 130,230 & 353,860 & 832,010 \\
\hline 1989 & 97,250 & 210,000 & 307,250 & 38,670 & 242,440 & 89,790 & 332,230 & 678,150 \\
\hline 1990 & 78,930 & 105,000 & 183,930 & 18,195 & 648,600 & 112,355 & 760,955 & 963,080 \\
\hline 1991 & 51,247 & 130,000 & 181,247 & 16,894 & 205,805 & 110,850 & 316,655 & 514,796 \\
\hline 1992 & 6,740 & 65,000 & 71,740 & 12,875 & 211,812 & 148,022 & 359,834 & 444,449 \\
\hline 1993 & 25,216 & -- & 25,216 & -- & 124,325 & 127,990 & 252,315 & 277,531 \\
\hline 1994 & 21,000 & -- & 21,000 & 8,168 & 347,018 & 91,692 & 438,710 & 467,878 \\
\hline 1995 & 27,570 & -- & 27,570 & - & 363,690 & 51,795 & 415,485 & 443,055 \\
\hline 1996 & 61,780 & -- & 61,780 & 8,500 & 524,330 & 134,527 & 658,857 & 729,137 \\
\hline 1997 & 38,980 & -- & 38,980 & 13,998 & 523,676 & 180,834 & 704,510 & 757,488 \\
\hline 1998 & 33,250 & -- & 33,250 & 2,300 & 505,408 & 45,670 & 551,078 & 586,628 \\
\hline 1999 & 6,727 & -- & 6,727 & -- & 369,863 & 78,934 & 448,797 & 455,524 \\
\hline 2000 & 15,480 & -- & 15,480 & - & 418,630 & 127,638 & 546,268 & 561,748 \\
\hline 2001 & 1,100 & -- & 1,100 & 36,151 & 240,318 & 75,750 & 316,068 & 353,319 \\
\hline 2002 & 1,250 & -- & 1,250 & - & 385,290 & 103,612 & 488,902 & 490,152 \\
\hline 2003 & 10,108 & -- & 10,108 & 2,000 & 270,456 & 100,178 & 370,634 & 382,742 \\
\hline 2004 & 107,526 & -- & 107,526 & - - & 415,628 & 36,024 & 451,652 & 559,178 \\
\hline 2005 & 3,360 & -- & 3,360 & - - & 592,497 & 41,780 & 634,277 & 637,637 \\
\hline 2006 & 8,759 & -- & 8,759 & 7,500 & 765,363 & 54,173 & 819,536 & 835,795 \\
\hline 2007 & 19,575 & -- & 19,575 & 50,539 & 830,478 & 268,112 & $1,098,590$ & $1,168,704$ \\
\hline 2008 & 1,216 & -- & 1,216 & 26,869 & 874,634 & 250,278 & $1,124,912$ & $1,152,997$ \\
\hline 2009 & 1,244 & -- & 1,244 & W & 403,275 & 260,059 & 663,334 & 664,578 \\
\hline
\end{tabular}

${ }^{a}$ Core and rotary drilling not differentiated prior to 1987.

- - = Not reported.

$\mathrm{W}=$ withheld for confidentiality, included in hardrock rotary 


\section{GOVERNMENT ACTIONS}

The Alaska Division of Geological \& Geophysical Surveys (DGGS) in early 2009 released airborne magnetic and electromagnetic geophysical maps covering 442 square miles in the Mentasta-Slana survey area in the northern Chistochina mining district. The geophysical surveys were conducted by Fugro Airborne Surveys Corp. and managed by Stevens Exploration Management Corp. DGGS conducted geologic ground-truth mapping of about 113 square miles of the geophysical survey tract during July 2009. The Slate Creek map area is in the southern foothills of the Alaska Range about 140 miles southeast of Fairbanks and 20 miles east of Paxson. This mapping project is funded primarily by State Capital Improvements Project (CIP) funding, with supplementary Federal STATEMAP funding. The mapping project is part of DGGS's Airborne Geophysical/Geological Mineral Inventory (AGGMI) program, a special multi-year investment by the State of Alaska to expand Alaska's geologic and mineral resources knowledge base, catalyze future private-sector mineral exploration and development, and guide state planning. Geochemical data from the mapping study will be released in 2010 and a series of 1:50,000-scale geologic maps will be available in 2011.

During a 31-day field season in 2008, geologists from the DGGS Minerals Section mapped and sampled approximately 200 square miles in the eastern Bonnifield mining district as part of DGGS's AGGMI program. Geochemical data from the mapping study was released in 2009. A series of 1:50,000-scale geologic maps will be available in 2011 .

DGGS also conducted geologic fieldwork along the proposed gas pipeline corridor between Tetlin Junction and the Yukon Territory-Alaska border along the Alaska Highway during 2009. Surficial and bedrock mapping were completed at a scale of 1:63,360.

The State of Alaska, through DGGS, funded and acquired airborne magnetic, electromagnetic, and radiometric geophysical data for approximately 653 square miles of mixed state- and Native-owned lands centered on Moran Creek and Moran Dome in the Tanana and Melozitna quadrangles. The area has not been extensively explored, but the district contains known plutonic-related lode-gold prospects, and has the potential for hosting porphyry copper \pm molybdenum \pm gold, mesothermal, epithermal, proximal to distal skarn, and polymetallic vein deposits. Structurally controlled, stacked, gold-bearing quartz veins occur at the Gold Hill lode gold prospect. Survey data and maps for this area about 150 miles west-northwest of Fairbanks and 25 miles west of the village of Tanana will be released in 2010 .
To date, with an investment of $\$ 10.4$ million, almost 9.25 million acres (more than 14,400 square miles) of Alaska have been flown for detailed geophysical surveys and about 2.7 million acres of 1:63,360- and 1:50,000-scale geologic maps have been produced as part of the State-funded DGGS AGGMI Program (table 29). Federal monies from the U.S. Geological Survey's STATEMAP Program fund some of the geologic mapping within the AGGMI Program.

Table 30 shows the geophysical surveys flown in Alaska that were funded largely by federal monies through the U.S. Bureau of Land Management (BLM). No new surveys were acquired or released in 2009.

The DGGS Geologic Materials Center received mineral industry samples and data during the year. DGGS shipped approximately 10 tons of surface samples from Fairbanks to the Eagle River facility to be archived. Calista Corp. donated core and soil samples from the Nyac gold property in southwestern Alaska.

The Alaska Railroad Corp. made \$13.9 million in net income during 2009 from total revenue of $\$ 169.4$ million. Total assets grew from $\$ 854$ million in 2008 to $\$ 861$ million in 2009 . Freight amounted to $\$ 84.9$ million of the total revenue in 2009. Total freight tonnage, the railroad's core business, was 5.3 million tons. The railroad hauled more than 886,000 tons of coal from Usibelli Coal Mine to the Seward port in 2009 and set a new record for coal export to places like Asia and Chile. As part of the American Recovery and Reinvestment Act of 2009, the Alaska Railroad received nearly \$26 million in stimulus funding from the federal government for "shovel-ready" projects in Fairbanks, Seward, Talkeetna, and Anchorage. The U.S. Department of Defense made a one-time appropriation of $\$ 60$ million for the Tanana River access project in support of the Northern Rail Extension Program. The Alaska Railroad and Aurora Energy Services, an affiliate of Usibelli Coal Mine Inc., were sued in December 2009 under the Federal Water Pollution Control Act (also known as the Clean Water Act) by the Alaska Community Action on Toxics and the Alaska Chapter of the Sierra Club for alleged violations regarding coal dust emissions at the Seward Coal Loading Facility at the southern terminus of the Alaska Railroad.

BLM adjusted fees for the staking and maintenance of unpatented mining claims, mill sites, and tunnel sites. The staking fee increased 13.3 percent (to $\$ 34$ from $\$ 30$ ), and the maintenance fee increased 12 percent (to $\$ 140$ from $\$ 125)$ for such unpatented claims in which no federal land has been transferred to the individual or company staking the claim. The higher fees were 
due on or before September 1, 2009. Mining claimants must pay the new location fee for any mining claim or site located after June 29, 2009. Parties that already submitted maintenance fees for the 2010 maintenance year were given an opportunity to pay the additional amount without penalty upon notice from BLM. The agency had not adjusted location and maintenance fees since 2004 and fee adjustments are required every five years at a minimum. The adjustments made in this final rule are based on the change in the Consumer Price Index between December 31, 2003 and December 31, 2008, as reported by the U.S. Bureau of Labor Statistics.

On August 25, 2009, Alaska Industrial Development and Export Authority (AIDEA) announced that the AIDEA Board approved execution of a new asset purchase and sale agreement that would continue the sale

\section{Table 29. Detailed state airborne geophysical surveys and follow-up geologic ground-truth mapping as of} December $2009^{a}$.

Nome District western core area

Nyac District core area

Circle District core area

Valdez Creek District

Fairbanks District

Richardson District

Rampart/Manley-Tofty

Upper Chulitna District

Petersville-Collinsville District

Iron Creek District

Ruby District

Fortymile District

Livengood District

Salcha River/North Pogo

Southeast extension of Salcha River-Pogo

Liberty Bell

Broad Pass

Council

Goodpaster River

Liscum $^{\circ}$

Black Mountain

East Richardson

Northeast Fairbanks

Alaska Highway Corridor ${ }^{\mathrm{d}}$

Bonnifield District

Styx River

Slate Creek-Slana River
494 sq. miles

183 sq. miles

338 sq. miles

78 sq. miles

626 sq. miles

137 sq. miles

1,017 sq. miles

364 sq. miles

415 sq. miles

689 sq. miles

591 sq. miles

1,036 sq. miles

229 sq. miles

1,032 sq. miles

91 sq. miles

276 sq. miles

304 sq. miles

618 sq. miles

210 sq. miles

67 sq. miles

222 sq. miles

224 sq. miles

404 sq. miles

3,045 sq. miles

602 sq. miles

710 sq. miles

442 sq. miles
Airborne geophysical survey geologic map

Airborne aeromagnetic survey

Airborne geophysical survey geologic map

Airborne geophysical survey

Airborne geophysical survey geologic map

Airborne geophysical survey

Airborne geophysical survey geologic map

Airborne geophysical survey geologic map

Airborne geophysical survey geologic map

Airborne geophysical survey geologic map

Airborne geophysical survey/published geologic map ${ }^{\mathrm{b}}$

Airborne geophysical survey geologic maps

Airborne geophysical survey geologic maps

Airborne geophysical survey geologic maps

Airborne geophysical survey

Airborne geophysical survey geologic map

Airborne geophysical survey

Airborne geophysical survey geologic map

Airborne geophysical survey geologic mapping (field work completed; map in prep.)

Airborne geophysical survey

Airborne geophysical survey

Airborne geophysical survey

Airborne geophysical survey geologic mapping (field work completed; map in prep.)

Airborne geophysical survey geologic mapping (field work completed; map in prep.)

Airborne geophysical survey geologic mapping (field work completed; map in prep.)

Airborne geophysical survey

Airborne geophysical survey

TOTAL 16 years $\quad \$ 10.4$ million $\quad 14,444$ sq. miles $\quad 2.53 \%$ of Alaska's total area

aProjects funded by the Alaska State Legislature. Projects concentrate on state, Native, state-selected, and Native-selected lands and are managed by DGGS.

${ }^{b}$ DGGS published a geologic map of the Ruby-Poorman mining district based on mapping in 1984 by the Anaconda Minerals Co. 'Project funded through agreement with AngloGold Ashanti (USA) Exploration Inc.

dProject funded by the Alaska State Legislature as a \$2 million Capital Improvement Project to assess the geologic hazards and resource potential along the proposed natural gas pipeline corridor between Delta Junction and the Canada border.

eProject partially funded through agreement with Anglo American Exploration (USA) Inc. under the DGGS Mineral Industry Sponsorship Program.

Note: Surveys listed above are complete except where noted. Additional areas will be scheduled for surveying at later dates contingent on future funding. 
Table 30. Detailed federally funded airborne geophysical survey work as of December 2009ª

\begin{tabular}{|c|c|c|}
\hline Wrangell/Stikine ${ }^{\mathrm{b}}$ & 1,111 sq. miles & Airborne geophysical survey \\
\hline Koyukuk/Wiseman & 533 sq. miles & Airborne geophysical survey \\
\hline Ketchikan $^{\mathrm{c}}$ & 605 sq. miles & Airborne geophysical survey \\
\hline Aniak & 1,240 sq. miles & Airborne geophysical survey \\
\hline Delta River & 603 sq. miles & Airborne geophysical survey \\
\hline Sleetmute & 641 sq. miles & Airborne geophysical survey \\
\hline Howard Pass-Misheguk Mountain & 1,447 sq. miles & Airborne geophysical survey \\
\hline Western Fortymile & 250 sq. miles & Airborne geophysical survey \\
\hline TOTAL 9 years & 6,430 sq. miles & $1.1 \%$ of Alaska's total area \\
\hline \multicolumn{3}{|c|}{$\begin{array}{l}\text { aProjects funded mainly by U.S. Bureau of Land Management with contributions by DGGS, local and state governments, and private corpo- } \\
\text { rations. Projects concentrate mainly on federal land. Data are released through DGGS. } \\
{ }^{\mathrm{b}} \text { Major funding came from BLM and the City of Wrangell. } \\
{ }^{\mathrm{c} M a j o r} \text { funding came from BLM and Ketchikan Gateway Borough. Sealaska Corp., Alaska State Mental Health Land Trust Office, the City } \\
\text { of Coffman Cove, and the City of Thorne Bay also contributed funds. Sealaska Corp. also contributed previously acquired geophysical } \\
\text { data. }\end{array}$} \\
\hline
\end{tabular}

and transfer of the Healy Clean Coal Project (HCCP) to Tri-Valley Electric Cooperative, a wholly-owned subsidiary of Golden Valley Electric Association. The new agreement terminated the February 13, 2009, asset purchase and sale agreement (which included Homer Electric Association's participation) upon execution of the new agreement.

In November 2009, the Alaska Department of Natural Resources presented its 2009 Annual Reclamation Awards for exceptional mine reclamation to Sheldon Maier for reclamation work associated with a placer mine on Montana Creek in the Fortymile District; to Eric Pyne for reclamation work associated with a placer mine on California Creek in the Koyukuk District; and to Usibelli Coal Mine Inc. for its reclamation work in Gold Run Pass and the Hoseanna Creek valley in the Healy area.

The U.S. Forest Service received \$1.4 million in federal stimulus money to clean up the abandoned Salt Chuck Mine on Prince of Wales Island. The historical mine was active between 1919 and 1941 and reportedly produced 300,000 tons of copper sulfide ore grading 0.95 percent copper, 0.058 ounces of palladium per ton, 0.032 ounces of gold per ton, and 0.166 ounces of silver per ton. The specific cleanup work won't be finalized until coordination with other owners of the site, including the State of Alaska and the Organized Village of Kasaan. The Organized Village of Kasaan is the tribal government for the small Haida village on east Prince of Wales Island. The work will focus on the Forest Service-owned portion and not the state's tidelands, with the options ranging from posting more signs to barging contaminated soil to the Lower 48. Besides getting rid of the contaminants, the Forest Service is considering the removal of dilapidated structures.
The U.S. Forest Service also received \$1.4 million for cleanup efforts at Resurrection Creek, a historical gold mining site near Hope.

The Alaska Department of Labor and Workforce Development announced a first-of-its-kind apprenticeship program to deliver core driller training. The intensive core driller training program is a collaborative effort of the Alaska Department of Labor and Workforce Development's Office of Apprenticeship, the U.S. Department of Labor Employment Training Administration's Office of Apprenticeship, the University of Alaska's Mining and Petroleum Training Service, and the mining industry. Registered apprenticeship combines on-the-job learning with classroom instruction, with a progressive pay scale so that participants earn while they learn. Apprenticeship, with nationally recognized certification, allows Alaskans to compete locally and globally in the mining industry. Employers can establish the standards of proficiency while developing a local and loyal work force. The first 18 participants, all registered apprentices, graduated April 22 at the Alaska Technical Center in Kotzebue.

The United States Geological Survey (USGS) awarded grants in 2009 through the USGS Mineral Resources External Research Program for two projects in Alaska. The focus of one study will be the uranium and rare earth deposits within the Bokan Mountain Granite complex, and will be conducted by a group of researchers from four Canadian universities, led by Dr. Jaroslav Dostal of the Department of Geology, Saint Mary's University, Halifax, Nova Scotia. This research is expected to provide further insight into the geological processes of deposit formation, while characterizing the granite complex that hosts the deposit at Bokan. In particular, the project aims to define the various types of mineralization, 
decipher the nature and origin of the uranium and REE mineralization, document the petrographic features and the chemical nature of the host peralkaline rocks, and supplement data as to their origin and tectonic settings. The study also may establish geochemical parameters to help distinguish ore-bearing from barren peralkaline granitic complexes.

The other USGS-funded study was awarded to Craig Hart of the University of Western Australia to investigate the regional geology and age of igneous rocks including those of the Pebble copper deposit in southwestern Alaska. The Pebble deposit is potentially one of the largest copper deposits of its type in the world. This research is expected to yield a better understanding of regional controls on the formation of the Pebble copper deposit and assist with the assessment for similar deposits that might be concealed in this region of Alaska where rocks are largely covered by younger material.

Geologists from the USGS, the Geological Survey of Canada, the British Columbia Geological Survey, and the Yukon Geological Survey conducted joint field work in 2009 as part of a collaborative research initiative involving detailed frontier geological mapping, airborne geophysics, paleontology, geochronology, and isotope studies, to help outline resource-rich environments for both scientific and economic benefit.

The U.S. Environmental Protection Agency (EPA) approved a request from the State of Alaska Department of Environmental Conservation (DEC) to run the National Pollutant Discharge Elimination System (NPDES). The NPDES program would give the state environmental regulators the ability to write wastewater discharge permits for local business and industry, as well as enforce those permits to ensure compliance. Alaska is phasing in implementation of the NPDES Program over three years. EPA will continue to write permits for those facilities that Alaska does not take on during this period. The transition will be complete by November 2011. In 2009, DEC issued a total of 145 authorizations under phases I and II of the transfer process.

On November 28, 2008, a petition (Akiak and others v. EPA) challenging EPA's approval of Alaska's NPDES primacy application was filed in the U.S. Ninth Circuit Court. The petitioners include several tribal councils, Cook Inlet Keeper, Alaska Center for the Environment, Alaska Community Action on Toxics, The Center for Biological Diversity, and the Center for Water Advocacy. The petitioners claim that the state's program does not comply with 40 CFR Statute123.30 (judicial review of permits) because the state's "loser pays" rule will deter potential litigants from challenging a permit decision in court. The petitioners also challenged the program based on the absence of administrative penalty authority and the loss of tribal consultation. DEC has filed to intervene in the case in support of EPA's decision.

DNR Resource Assessment and Development Section staff continued studies to revise the Yukon-Tanana Area Plan. The area covered by the proposed plan was the western portion of the existing Tanana Basin Area Plan. The existing area plan was adopted in 1985 and updated in 1991. The proposed plan encompasses more than 15 million acres of state-owned and non-stateowned land. DNR staff also continued studies for the companion Eastern Tanana Area Plan. This plan area contains approximately 6.5 million acres of general stateowned and state-selected lands, with numerous mineral resources and many areas of high mineral potential.

The U.S. Bureau of Land Management (BLM) continued studies to update the federal Eastern Interior Plan. The planning area is somewhat triangular in shape and is east of Fairbanks, running south of the Brooks Range to the Canada border and generally bounded on the south by the Richardson and Alaska highways. The plan area includes about 8 million acres of federally managed lands.

BLM is nearing the completion of the Accelerated Land Transfer Act. The agency has reached its near-term target of conveying 96 percent of the State of Alaska's land entitlement and 94 percent of the Alaska Native Claims Settlement Act (ANCSA) corporations. The majority of the land transferred is unsurveyed and will require a survey before exact acreage calculations can be made. The goal of the Accelerated Land Transfer Act was to complete land transfers from BLM to the State of Alaska and Alaska ANCSA regional corporations by 2009 .

Trustees for Alaska, an Anchorage-based environmental law firm, filed an appeal on March 18 against a miscellaneous land use permit granted to the Pebble Partnership by the Alaska Department of Natural Resources (DNR) on Feb. 26. The appeal, filed on behalf of Nunamta Aukulestai, Jack Hobson, and Rick Delkettie, is in response to DNR approving a multi-agency permit application that would allow the Pebble Partnership to conduct drilling and other planned research and exploration activities. The law firm cited a lack of proper public notice and a failure by DNR to analyze and verify baseline conditions as reasons for the appeal. Trustees for Alaska requested that a stay of approval be issued for the Pebble copper-gold-molybdenum project while the appeal is being decided.

Trustees for Alaska filed a civil suit in Anchorage Superior Court on July 29 contending that permits issued by DNR for exploration of the Pebble deposit in southwestern Alaska violate the Alaska Constitution. The lawsuit, filed on behalf of Nunamta Aulukestai, Jack Hobson, and former Alaska First Lady Bella Hammond, among others, claims the exploration and water 
use permits issued to Pebble's developers by DNR were illegally issued due to a lack of public notice and analysis of whether the permits are in the public's interest.

The Pebble Partnership, in conjunction with the Resource Development Council for Alaska, filed a complaint with the Alaska Public Offices Commission, alleging 18 violations of Alaska campaign law. The 20-page complaint, supported by 37 pages of evidence, outlined a joint effort by the Renewable Resources Coalition, Alaskans for Clean Water, and Americans for Job Security and investment manager Bob Gillam to conceal about \$2 million in contributions from Gillam in support of Ballot Measure 4 during Alaska's 2008 primary election.
A complaint was filed with the Alaska Public Offices Commission by Arthur Hackney on June 15, 2009, alleging Alaskans Against the Mining Shutdown, the Council of Alaska Producers, and NANA Regional Corporation conspired to hide $\$ 3.5$ million in expenditures and more than $\$ 1.3$ million in contributions in opposition to Ballot Measure 4 in 2008.

Minerals Specialist Rich Hughes retired from the Division of Economic Development in the Alaska Department of Commerce, Community \& Economic Development on June 30, 2010 (fig. 19). Rich's service as co-author of annual Alaska mineral industry reports for the past 7 years is gratefully acknowledged.

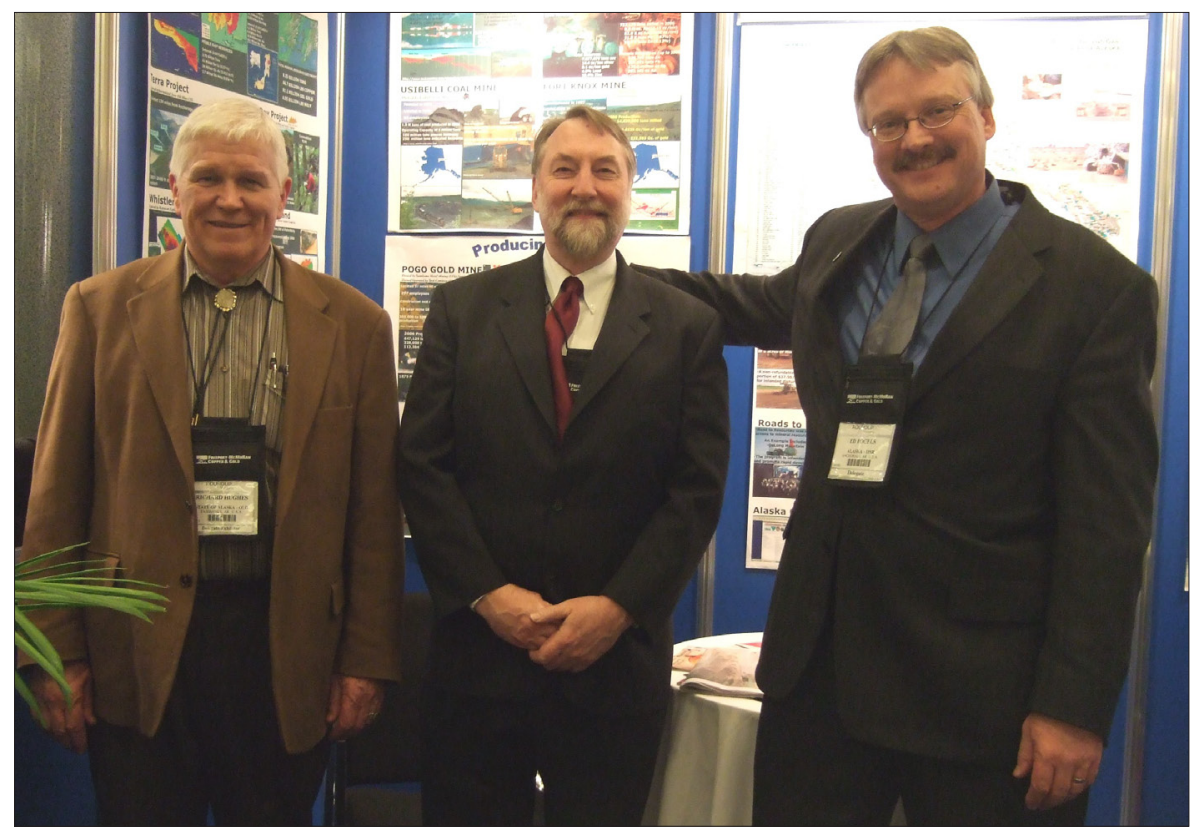

Figure 19. Rich Hughes (DCCED/Division of Economic Development), Rick Fredericksen (DNR/Division of Mining, Land \& Water), and Ed Fogels (DNR/ Office of Project Management \& Permitting) work the State of Alaska trade show booth at the Mineral Exploration Roundup 2008 conference. 

APPENDIX A

New claims staked in Alaska 2005-2009

\begin{tabular}{|c|c|c|c|c|c|c|c|c|c|c|c|}
\hline \multirow{2}{*}{$\begin{array}{r}\text { Quad } \\
\text { no. }\end{array}$} & \multirow{2}{*}{$\begin{array}{c}\text { Quadrangle } \\
\text { name }^{\mathrm{a}}\end{array}$} & \multicolumn{5}{|c|}{ New federal mining claims } & \multicolumn{5}{|c|}{ New state mining claims } \\
\hline & & 2005 & 2006 & 2007 & 2008 & 2009 & 2005 & 2006 & 2007 & $2008^{b}$ & 2009 \\
\hline 18 & De Long Mountains & 0 & 0 & 0 & 0 & 0 & 0 & 0 & 0 & & $\mathrm{u}$ \\
\hline 23 & Phillip Smith Mountains & 0 & 0 & 0 & 0 & 0 & 0 & 0 & 0 & & $\mathrm{u}$ \\
\hline 26 & Noatak & 0 & 0 & 0 & 0 & 0 & 0 & 0 & 0 & & $\mathrm{u}$ \\
\hline 27 & Baird Mountains & 0 & 0 & 0 & 0 & 0 & 20 & 260 & 4 & & $\mathrm{u}$ \\
\hline 28 & Ambler River & 0 & 0 & 0 & 0 & 0 & 313 & 15 & 57 & & $\mathrm{u}$ \\
\hline 29 & Survey Pass & 0 & 0 & 0 & 0 & 0 & 68 & 68 & 44 & & $\mathrm{u}$ \\
\hline 30 & Wiseman & 14 & 250 & 134 & 6 & 2 & 13 & 0 & 4 & 12 & $\mathrm{u}$ \\
\hline 31 & Chandalar & 25 & 30 & 0 & 3 & 11 & 13 & 68 & 173 & & $\mathrm{u}$ \\
\hline 36 & Selawik & 0 & 0 & 0 & 0 & 0 & 0 & 0 & 0 & & $\mathrm{u}$ \\
\hline 38 & Hughes & 0 & 0 & 0 & 0 & 0 & 0 & 0 & 20 & & $\mathrm{u}$ \\
\hline 39 & Bettles & 12 & 7 & 0 & 26 & 6 & 0 & 0 & 0 & & $\mathrm{u}$ \\
\hline 43 & Teller & 0 & 0 & 0 & 0 & 0 & 36 & 80 & 111 & & $\mathrm{u}$ \\
\hline 44 & Bendeleben & 0 & 0 & 0 & 0 & 0 & 55 & 405 & 632 & 500 & $\mathrm{u}$ \\
\hline 45 & Candle & 0 & 0 & 0 & 0 & 0 & 148 & 178 & 8 & & $\mathrm{u}$ \\
\hline 47 & Melozitna & 0 & 0 & 0 & 0 & 0 & 0 & 28 & 0 & & $\mathrm{u}$ \\
\hline 48 & Tanana & 0 & 0 & 0 & 0 & 0 & 45 & 46 & 52 & & $\mathrm{u}$ \\
\hline 49 & Livengood & 0 & 0 & 0 & 0 & 0 & 89 & 125 & 41 & 36 & $\mathrm{u}$ \\
\hline 50 & Circle & 0 & 0 & 0 & 0 & 0 & 126 & 147 & 101 & & $\mathrm{u}$ \\
\hline 51 & Charley River & 0 & 0 & 0 & 0 & 0 & 0 & 2 & 2 & & $\mathrm{u}$ \\
\hline 52 & Nome & 0 & 0 & 0 & 0 & 0 & 7 & 57 & 31 & & $\mathrm{u}$ \\
\hline 53 & Solomon & 0 & 0 & 9 & 0 & 0 & 48 & 56 & 25 & & $\mathrm{u}$ \\
\hline 55 & Nulato & 0 & 0 & 0 & 0 & 0 & 69 & 0 & 0 & & $\mathrm{u}$ \\
\hline 56 & Ruby & 0 & 0 & 0 & 0 & 0 & 0 & 9 & 15 & & $\mathrm{u}$ \\
\hline 58 & Fairbanks & 0 & 0 & 0 & 0 & 0 & 70 & 96 & 61 & 23 & $\mathrm{u}$ \\
\hline 59 & Big Delta & 0 & 0 & 0 & 0 & 0 & 988 & 2,218 & 153 & & $\mathrm{u}$ \\
\hline 60 & Eagle & 0 & 0 & 0 & 0 & 0 & 230 & 257 & 589 & & $\mathrm{u}$ \\
\hline 64 & Ophir & 0 & 0 & 0 & 0 & 0 & 1 & 0 & 61 & 20 & $\mathrm{u}$ \\
\hline 65 & Medfra & 0 & 0 & 0 & 0 & 0 & 0 & 12 & 33 & & $\mathrm{u}$ \\
\hline 67 & Healy & 0 & 0 & 0 & 0 & 0 & 149 & 47 & 271 & & $\mathrm{u}$ \\
\hline 68 & Mt. Hayes & 253 & 0 & 4 & 0 & 0 & 84 & 429 & 127 & & $\mathrm{u}$ \\
\hline 69 & Tanacross & 0 & 0 & 0 & 0 & 0 & 0 & 34 & 410 & 140 & $\mathrm{u}$ \\
\hline 73 & Iditarod & 0 & 0 & 0 & 0 & 0 & 1 & 589 & 302 & 178 & $\mathrm{u}$ \\
\hline 74 & McGrath & 0 & 0 & 0 & 0 & 0 & 0 & 139 & 72 & & $\mathrm{u}$ \\
\hline 75 & Talkeetna & 0 & 0 & 0 & 0 & 0 & 178 & 383 & 62 & 10 & $\mathrm{u}$ \\
\hline 76 & Talkeetna Mountains & 0 & 0 & 0 & 0 & 0 & 234 & 65 & 72 & & $\mathrm{u}$ \\
\hline 77 & Gulkana & 0 & 0 & 0 & 0 & 0 & 0 & 103 & 85 & & $\mathrm{u}$ \\
\hline 78 & Nabesna & 0 & 0 & 0 & 0 & 0 & 1 & 0 & 56 & & $\mathrm{u}$ \\
\hline 81 & Russian Mission & 0 & 0 & 0 & 0 & 0 & 0 & 160 & 0 & & $\mathrm{u}$ \\
\hline 82 & Sleetmute & 0 & 0 & 0 & 0 & 0 & 6 & 25 & 753 & & $\mathrm{u}$ \\
\hline 83 & Lime Hills & 0 & 0 & 0 & 0 & 0 & 271 & 122 & 281 & 156 & $\mathrm{u}$ \\
\hline 84 & Tyonek & 0 & 0 & 0 & 0 & 0 & 113 & 125 & 81 & & $\mathrm{u}$ \\
\hline 85 & Anchorage & 0 & 0 & 0 & 0 & 0 & 80 & 72 & 66 & & $\mathrm{u}$ \\
\hline 86 & Valdez & 0 & 0 & 0 & 0 & 0 & 1 & 48 & 1 & & $\mathrm{u}$ \\
\hline 91 & Bethel & 0 & 0 & 0 & 0 & 0 & 8 & 154 & 516 & & $\mathrm{u}$ \\
\hline 92 & Taylor Mountains & 0 & 0 & 0 & 0 & 0 & 26 & 55 & 10 & & $\mathrm{u}$ \\
\hline 93 & Lake Clark & 0 & 0 & 0 & 0 & 0 & 866 & 87 & 831 & & $\mathrm{u}$ \\
\hline 95 & Seward & 18 & 13 & 29 & 26 & 24 & 7 & 12 & 18 & & $\mathrm{u}$ \\
\hline 96 & Cordova & 0 & 0 & 0 & 0 & 0 & 0 & 0 & 0 & & $\mathrm{u}$ \\
\hline 101 & Goodnews Bay & 0 & 0 & 0 & 0 & 0 & 0 & 0 & 0 & & $\mathrm{u}$ \\
\hline 102 & Dillingham & 0 & 0 & 0 & 0 & 0 & 147 & 0 & 99 & & $\mathrm{u}$ \\
\hline 103 & Iliamna & 0 & 0 & 0 & 0 & 0 & 318 & 26 & 171 & & $\mathrm{u}$ \\
\hline 104 & Seldovia & 0 & 0 & 0 & 0 & 0 & 0 & 0 & 0 & & $\mathrm{u}$ \\
\hline 105 & Blying Sound & 0 & 0 & 0 & 0 & 0 & 0 & 0 & 4 & & $\mathrm{u}$ \\
\hline 108 & Yakutat & 0 & 0 & 0 & 2,383 & 820 & 0 & 0 & 41 & & $\mathrm{u}$ \\
\hline
\end{tabular}




\begin{tabular}{|c|c|c|c|c|c|c|c|c|c|c|c|}
\hline \multirow{2}{*}{$\begin{array}{r}\text { Quad } \\
\text { no. }\end{array}$} & \multirow{2}{*}{$\begin{array}{c}\text { Quadrangle } \\
\text { name }^{\mathrm{a}}\end{array}$} & \multicolumn{5}{|c|}{ New federal mining claims } & \multicolumn{5}{|c|}{ New state mining claims } \\
\hline & & 2005 & 2006 & 2007 & 2008 & 2009 & 2005 & 2006 & 2007 & $2008^{b}$ & 2009 \\
\hline 109 & Skagway & 0 & 0 & 0 & 0 & 0 & 4 & 20 & 100 & & $\mathrm{u}$ \\
\hline 112 & Juneau & 0 & 1 & 67 & 199 & 43 & 2 & 7 & 0 & & $\mathrm{u}$ \\
\hline 114 & Sitka & 0 & 0 & 9 & 0 & 0 & 0 & 0 & 1 & & $\mathrm{u}$ \\
\hline 115 & Sumdum & 0 & 0 & 0 & 40 & 0 & 0 & 0 & 0 & & $\mathrm{u}$ \\
\hline 116 & Port Alexander & 0 & 0 & 0 & 2 & 0 & 0 & 0 & 0 & & $\mathrm{u}$ \\
\hline 117 & Petersburg & 1 & 54 & 23 & 0 & 0 & 0 & 0 & 0 & & $\mathrm{u}$ \\
\hline 118 & Bradfield Canal & 0 & 0 & 0 & 1 & 0 & 0 & 0 & 0 & & $\mathrm{u}$ \\
\hline 119 & Craig & 83 & 94 & 365 & 64 & 150 & 2 & 0 & 0 & & $\mathrm{u}$ \\
\hline 120 & Ketchikan & 0 & 0 & 0 & 0 & 0 & 0 & 0 & 0 & & $\mathrm{u}$ \\
\hline 121 & Dixon Entrance & 13 & 8 & 293 & 176 & 1 & 0 & 0 & 0 & & $\mathrm{u}$ \\
\hline 122 & Prince Rupert & 0 & 0 & 0 & 75 & 0 & 0 & 0 & 0 & & $\mathrm{u}$ \\
\hline 128 & Bristol Bay & 0 & 0 & 0 & 0 & 0 & 10 & 0 & 0 & & $\mathrm{u}$ \\
\hline 129 & Ugashik & 0 & 0 & 0 & 0 & 0 & 0 & 16 & 0 & & $\mathrm{u}$ \\
\hline 130 & Karluk & 0 & 0 & 0 & 0 & 0 & 0 & 0 & 0 & & $\mathrm{u}$ \\
\hline 131 & Kodiak & 0 & 0 & 0 & 0 & 0 & 1 & 0 & 0 & & $\mathrm{u}$ \\
\hline 133 & Chignik & 0 & 0 & 0 & 0 & 0 & 6 & 0 & 0 & & $\mathrm{u}$ \\
\hline 135 & Trinity Islands & 0 & 0 & 0 & 0 & 0 & 383 & 13 & 1 & & $\mathrm{u}$ \\
\hline 136 & Kaguyak & 0 & 0 & 0 & 0 & 0 & 71 & 0 & 0 & & $\mathrm{u}$ \\
\hline & TOTALS & 419 & 457 & 933 & 3,001 & 1,057 & 5,308 & 6,858 & 6,648 & 1,075 & $\mathbf{u}$ \\
\hline
\end{tabular}

anlisted quadrangles did not have any staked mining claims between 2003 and 2008 .

*Eight federal claims extend over two quadrangles.

bState mining claim information is estimated and not complete.

$\mathrm{u}=$ New state mining claim data for 2009 was unavailable by press deadline. The division intends to publish the data in the online version of this booklet (available at no charge from the DGGS website, dggs.alaska.gov).

Source: Data provided by Alaska Department of Natural Resources Land Records Information Section and U.S. Bureau of Land Management. 


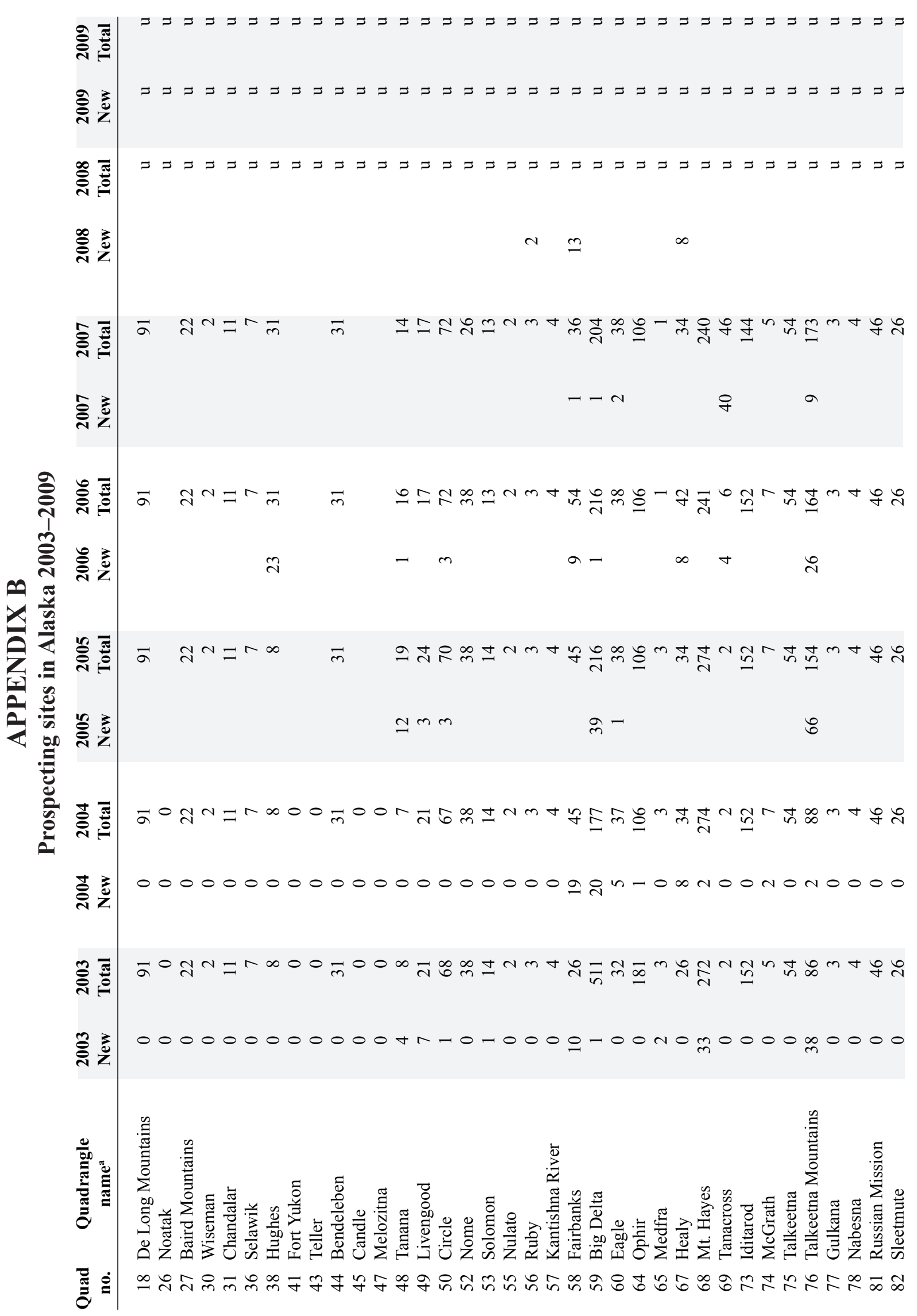




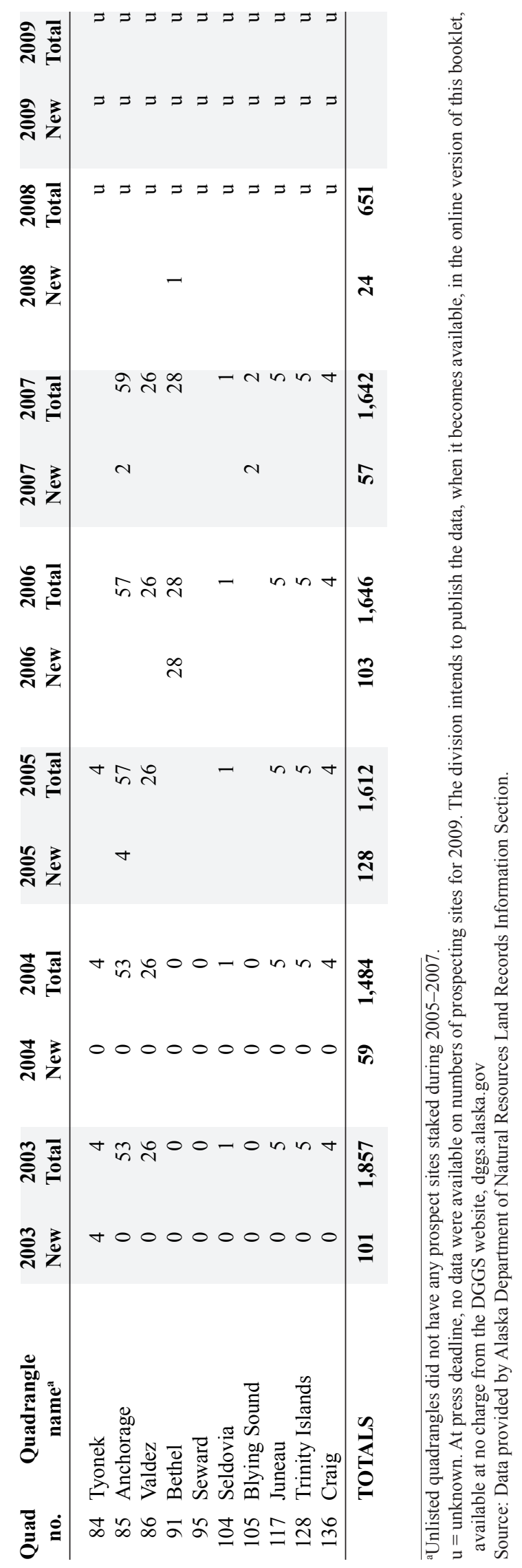




\section{APPENDIX C}

\section{Selected significant mineral deposits and mineral districts in Alaska ${ }^{a}$}

The alphabetized list of mineral deposits and mineral districts is keyed to the list of explanatory paragraphs that follow. For example, The Lik deposit in the alphabetized list is "Lik, 1, (fig. C-1)." This says that the location of Lik is shown as number 1 in figure $\mathrm{C}-1$.

Alaska-Juneau, 100, (fig. C-3).

Anderson Mountain, 54, (fig. C-1).

Aniak district, 84, (fig C-3).

Apex-EI Nido, 104, (fig. C-3).

Apollo-Sitka mines, 86, (fig. C-3).

Arctic, 9, (fig. C-1).

Avan Hills, 12, (fig. C-3).

Baultoff, 75, (fig. C-2)

Bear Mountain, 21, (fig. C-2).

Big Creek/Ladue, 58, (fig. C-1).

Big Hurrah, 32, (fig. C-3).

Binocular and other prospects, 72, (fig. C-1).

Bohemia Basin, 103, (fig. C-3).

Bokan Mountain, 122, (fig. C-3).

Bonanza Creek, 45, (fig. C-2).

Bond Creek, 73, (fig. C-2).

Bonnifield district massive sulfide deposits, 54, (fig. C-1).

Bornite, 8, (fig. C-1).

Brady Glacier, 98, (fig. C-3).

BT, 54, (fig. C-1).

Buck Creek, 23, (fig. C-2)

Calder Mine, 133, (fig C-2).

Canwell and Nikolai Complex, 140

(fig. C-3)

Cape Creek, 22, (fig. C-2).

Carl Creek, 74, (fig. C-2).

Casca VABM, 53, (fig. C-1).

Castle Island, 111, (fig. C-1).

Chandalar mining district, 17, (fig. C-3).

Chichagof, 101, (fig. C-3).

Chistochina, 68, (figs. C-2, C-3).

Circle mining district, 52, (fig. C-3).

Claim Point, 82, (fig. C-3).

Coal Creek, 63, (fig. C-2).

Copper City, 119, (fig. C-1).

Cornwallis Peninsula, 110, (fig. C-1).

Council mining district, 33 , (fig. C-3).

Delta massive sulfide belt, 55, (fig. C-1).

Denali prospect, 67, (fig. C-1).

Dolphin, 49e, (fig. C-3).

Donlin Creek, 137, (fig. C-3).

Drenchwater, 3, (fig. C-1).

Dry Creek, 54, (fig. C-1).

Duke Island, 141 (fig. C-3)

Eagle Creek, 34, (fig. C-3).

Ear Mountain, 25, (fig. C-2).

Ellamar, 78, (fig. C-1).

Ernie Lake (Ann Creek), 15, (fig. C-1).

Esotuk Glacier, 20, (fig. C-2).

Fairbanks mining district, 49, (fig. C-3).

Fairhaven/Inmachuk district, 39, (fig. C-3).

Fort Knox, 49a, (fig. C-3).

Fortymile mining district, 60, (fig. C-3).

Frost, 7a, (fig. C-1).

Funter Bay mining district, 99, (fig. C-3).

Galena Creek, 21a, (fig. C-1).

Gil Claims, 49f, (fig. C-3).
Ginny Creek, 4, (fig. C-1).

Golden Zone mine, 64, (figs. C-1, C-3).

Goodnews Bay, 85, (fig. C-3).

Grant Mine, 49c, (fig. C-3).

Greens Creek, 105, (fig. C-1).

Groundhog Basin, 112, (fig. C-1).

Haines Barite/Palmer, 95, (fig. C-1).

Hannum, 27, (fig. C-1).

Hirst Chichagof, 101, (fig. C-3).

Horsfeld, 76, (fig. C-2).

Hot Springs mining district, 47 , (figs. C-2, C-3).

Hyder mining district, 117, (figs. C-1, C-2).

Iditarod district, 43, (fig. C-3).

Illinois Creek, 132, (figs. C-1, C-3).

Independence, 79, (fig. C-3).

Independence Creek, 28, (fig. C-1).

Inmachuk River, 39, (fig. C-3).

Innoko-Tolstoi mining district, 44, (fig. C-3).

Ivanof, 88 , (fig. C-2).

Jimmy Lake, 94, (fig. C-1).

Johnson River, 125, (fig. C-3).

Jualin, 128, (fig. C-3).

Jumbo, 118, (fig. C-1).

Kaiyah, 138, (fig. C-3).

Kantishna mining district, 61, (fig. C-3).

Kasaan Peninsula, 114, (fig. C-1).

Kasna Creek, 92, (fig. C-1).

Kemuk Mountain, 123, (fig. C-3).

Kennecott deposits, 71, (fig. C-1).

Kensington, 127, (fig. C-3).

Kivliktort Mountain, 5a, (fig. C-1).

Klery Creek, 14, (fig. C-3).

Klukwan, 96, (fig. C-3).

Kougarok Mountain, 26, (fig. C-2).

Koyukuk-Hughes mining district, 42 , (fig. C-3).

Koyukuk-Nolan mining district, 16, (fig. C-3).

Latouche, Beatson, 80, (fig. C-1).

Liberty Bell, 54, (fig. C-1)

Lik, 1, (fig. C-1).

Livengood-Tolovana mining district, 48 , (fig. C-3).

Lost River, 24, (fig. C-2).

Lucky Shot, 79, (fig. C-3).

McLeod, 124, (fig. C-2).

Mertie Lode, 99, (fig. C-3).

Midas mine, 77, (fig. C-1).

Mike deposit, 90, (fig. C-2).

Mirror Harbor, 102, (fig. C-3).

Misheguk Mountain, 13, (fig. C-3).

Mosquito, Peternie, 56, (fig. C-2).

Mt. Prindle, 50, (fig. C-3).

Nabesna mine, 69, (fig. C-3).

Niblack, 121, (fig. C-1).

Nim prospect, 65 , (fig. C-1).

Nimiuktuk River, 126, (fig. C-1).
Nixon Fork, 135, (fig. C-3).

Nome mining district, 30, (fig. C-3).

Nunatak, 97, (fig. C-2).

Omalik, 35, (fig. C-1).

Omar, 7, (fig. C-1).

Orange Hill, 73, (fig. C-2).

Pebble Copper, 129, (fig. C-1).

Placer River, 38, (fig. C-2).

Pleasant Creek, 53, (fig. C-1).

Pogo, 130, (fig. C-3).

Poovookpuk Mountain, 40, (fig. C-2).

Porcupine Lake, 18, (fig. C-2).

Purcell Mountain, 41, (fig. C-2).

Pyramid, 87, (fig. C-2).

Quartz Creek, 37, (fig. C-1).

Quartz Hill, 120, (fig. C-2).

Red Bluff Bay, 109, (fig. C-3).

Red Devil, 83, (fig. C-3).

Red Dog, 2, (fig. C-1).

Red Mountain, 82, (fig. C-3).

Rex deposit, 91, (fig. C-2).

Rock Creek, 31, (fig. C-3).

Rua Cove, 81, (fig. C-1).

Ruby mining district, 46, (fig. C-3).

Ryan Lode, 49b, (fig. C-3).

Salt Chuck, 115, (fig. C-3).

Sheep Creek, 54, (fig. C-1).

Shotgun Hills, 131, (fig. C-3).

Shulin Lake, 139 (fig. C-3)

Sinuk River region, 29, (fig. C-1).

Slate Creek, 59, (fig. C-3).

Sleitat Mountain, 93, (fig. C-2).

Smucker, 11, (fig. C-1).

Snettisham, 107, (fig. C-3).

Snipe Bay, 113, (fig. C-3).

Solomon mining district, 33, (fig. C-3).

Spirit Mountain, 70, (fig. C-3).

Stampede mine, 62, (fig. C-3).

Story Creek, 5, (fig. C-1).

Sumdum, 106, (fig. C-1).

Sun, 10, (fig. C-1).

Taurus, 57, (fig. C-2).

Three Castle Mountain, 53, (fig. C-1).

Tracy Arm, 108, (fig. C-1).

True North, 49d, (fig. C-3).

Twin Mountain, 51, (fig. C-2).

Union Bay, 116, (fig. C-3).

Valdez Creek district, 66, (fig. C-3).

Vinasale Mountain, 134, (fig. C-3)

Virginia Creek, 54, (fig. C-1).

Von Frank Mountain, 136, (fig. C-3).

War Baby, 79, (fig. C-3).

Weasel Mountain, Bee Creek, 89, (fig. C-2)

Whoopee Creek, 6, (fig. C-1).

Willow Creek, 79, (fig. C-3).

Wind River, 19, (fig. C-1).

Windy Creek, 36, (fig. C-2).

Zackly, 67a, (fig. C-1).

$\overline{{ }^{a}}$ This generalized summary does not describe all of the 7,000 known mineral occurrences in Alaska. NOTE: In cooperation with DGGS and the Russian Academy of Sciences, the USGS published Open-File Report 93-339 (Nokleberg and others, 1993), Metallogenesis of mainland Alaska and the Russian northeast, which describes 273 lode deposits and 43 significant placer districts in Alaska. 


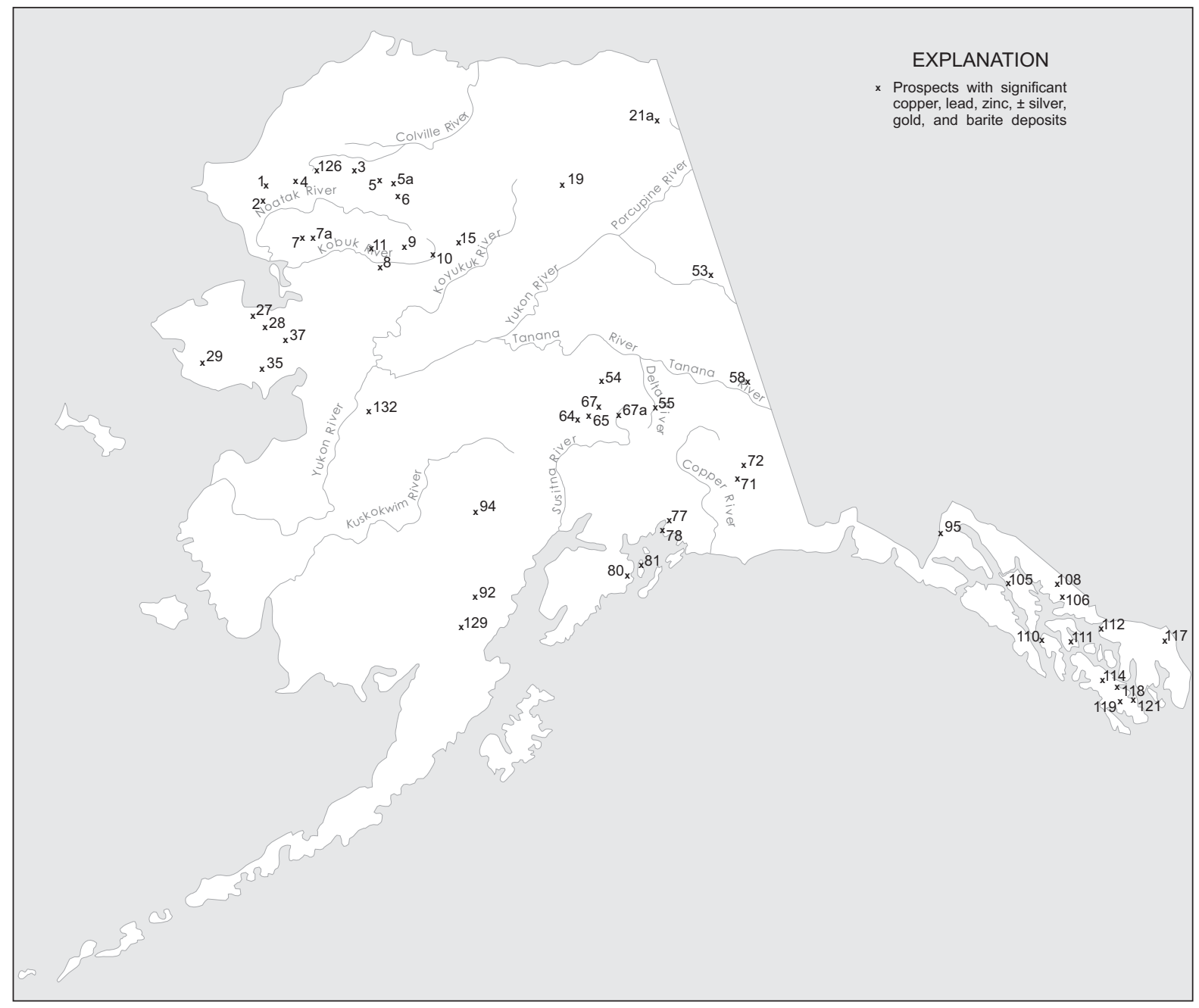

Figure C-1. Significant copper, lead, zinc with credits of silver, gold, and barite deposits in Alaska, 2009.

\section{Map no.}

1 Lik-Major stratabound massive sulfide $(\mathrm{Zn}-\mathrm{Pb}-\mathrm{Ag}-$ Ba) deposit in black shale and chert. Proven reserve (Lik) estimate of 24 million tons of $9 \% \mathrm{Zn}, 3.1 \% \mathrm{~Pb}$, and $1.4 \mathrm{oz} /$ ton $\mathrm{Ag}$ (fig. C-1).

2 Red Dog-At least five major stratabound massive sulfide deposits hosted in Pennsylvanian or Mississippian shale; similar to locality 1 . Mining from 1989 to 2006 produced 7.7 million tons of $\mathrm{Zn}, 1.35$ million tons of $\mathrm{Pb}$, and 74.4 million oz Ag. Deposits, with announced reserves from 2000, include: (a) The Main deposit at Red Dog contains 46.2 million tons of proven ore grading $19.2 \% \mathrm{Zn}, 5.2 \% \mathrm{~Pb}$, with 2.92 oz/ton Ag. (b) The Aqqaluk deposit contains probable, indicated, and inferred reserves of 73.0 million tons grading $15.2 \% \mathrm{Zn}, 4.03 \% \mathrm{~Pb}$, and $2.17 \mathrm{oz} /$ ton $\mathrm{Ag}$. (c) The Qanaiyaq (formerly named Hilltop) deposit with an indicated reserve is 10.6 million tons grading $17.8 \% \mathrm{Zn}, 5.5 \% \mathrm{~Pb}$, and $3.41 \mathrm{oz} /$ ton $\mathrm{Ag}$. (d) Inferred resource in the Paalaaq deposit is 14.3 million tons of $15.0 \% \mathrm{Zn}, 4.0 \% \mathrm{~Pb}$, and $2.63 \mathrm{oz} /$ ton Ag. (e) Anarraq deposit discovered in 1999 has an inferred reserve of 19.0 million tons of $15.8 \% \mathrm{Zn}, 4.8 \% \mathrm{~Pb}$, and 2.07 oz/ton Ag (fig. C-1).

3 Drenchwater-Mississippian and Pennsylvanian shales and cherts contain three stratabound base metal occurrences spatially related to acid volcanics. The lowest unit, a siliceous mudstone, contains a $2 \mathrm{ft}$ layer with up to $23 \% \mathrm{Zn}$. An overlying gray chert contains up to $11 \% \mathrm{Zn}$ and up to $5 \% \mathrm{~Pb}$ with some $\mathrm{Ag}$ in fracture fillings. At the top of the overlying tuffaceous layer, Ag-bearing $\mathrm{Zn}$ and $\mathrm{Pb}$ mineralization outcrops discontinuously for at least $6,500 \mathrm{ft}$, and contains up to $26 \% \mathrm{Zn}$ and $51 \% \mathrm{~Pb}$ in grab samples (fig. C-1).

4 Ginny Creek-Epigenetic, disseminated $\mathrm{Zn}-\mathrm{Pb}-\mathrm{Ag}$ deposits with barite in sandstone and shale of Late Devonian through Early Mississippian Noatak Sandstone. Random grab samples of float contain $0.3 \%$ to $3.0 \% \mathrm{Zn}$ and highly variable amounts of $\mathrm{Pb}$ and Ag (fig. C-1).

5 Story Creek-Epigenetic replacement deposits of $\mathrm{Zn}-\mathrm{Pb}-\mathrm{Ag}-\mathrm{Cu}-\mathrm{Au}$ hosted in brecciated zones in Devonian Kanayut Conglomerate or Lower Mississippian Kayak Shale. Grab samples of high- 


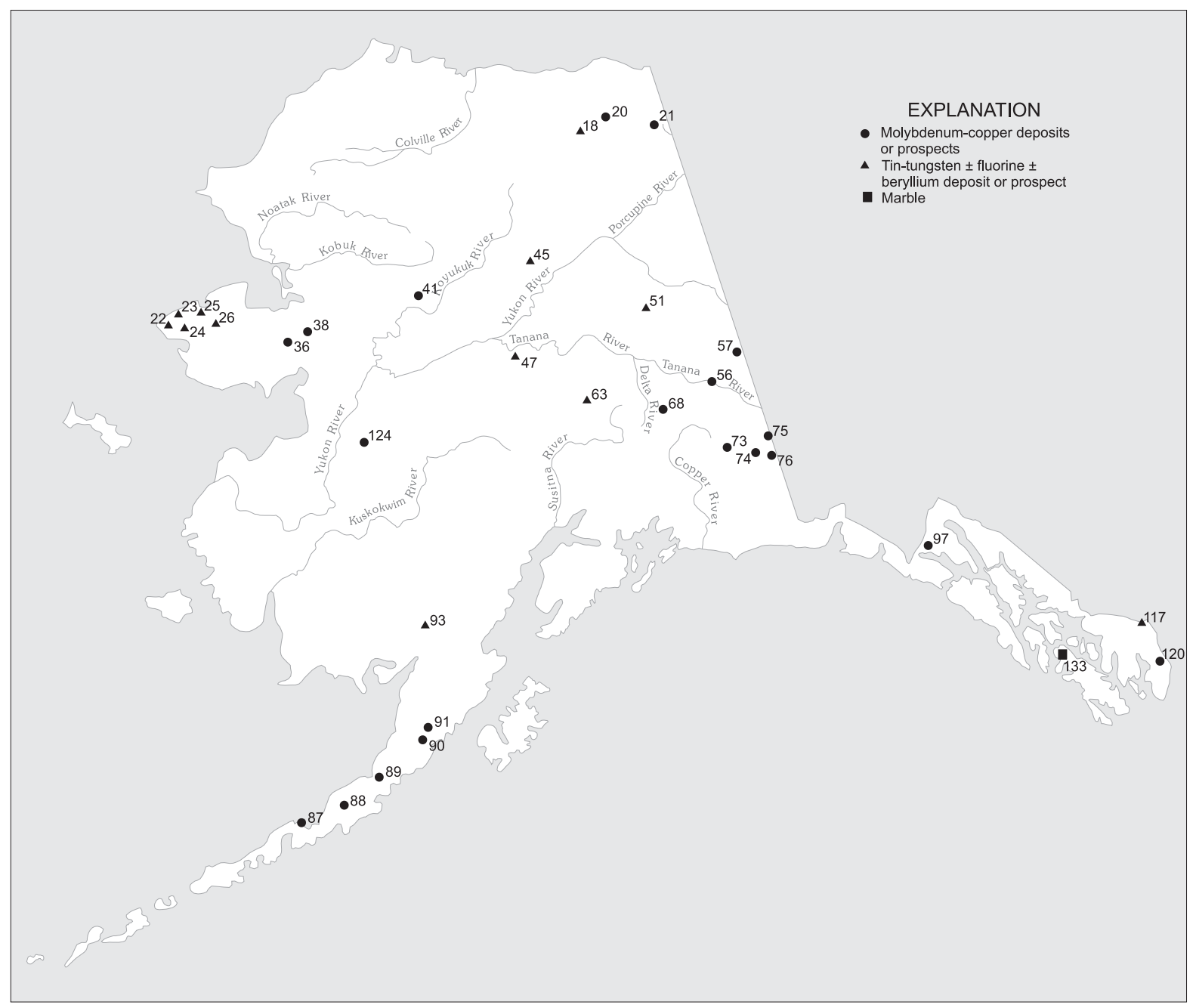

Figure C-2. Significant molybdenum-copper and tin-tungsten with credits of fluorite and beryllium deposits in Alaska, 2009.

grade material contain up to $0.43 \% \mathrm{Cu}, 34 \% \mathrm{~Pb}$, $28.8 \% \mathrm{Zn}, 0.04 \mathrm{oz} /$ ton $\mathrm{Au}$, and $30 \mathrm{oz} /$ ton $\mathrm{Ag}$ (fig. C-1).

5a Kivliktort Mountain-Mineralized float is widespread on the north flanks of the mountain, apparently spatially related to the contact between shales at the base of the hills and coarse-grained siliceous clastic rocks on the upper slopes. Rock samples containing up to $30 \% \mathrm{Zn}$ have been reported (fig. C-1).

6 Whoopee Creek-Epigenetic replacement deposits of $\mathrm{Zn}-\mathrm{Pb}-\mathrm{Cu}-\mathrm{Ag}-\mathrm{Au}-\mathrm{Cd}$ in breccia zones in Devonian Kanayut Conglomerate or Lower Mississippian Kayak Shale. Random grab samples of mineralized material contain $0.24 \% \mathrm{Cu}, 0.37 \% \mathrm{Cd}, 46 \% \mathrm{Zn}, 44 \% \mathrm{~Pb}, 0.14$ oz/ton $\mathrm{Au}$, and $14.8 \mathrm{oz} /$ ton $\mathrm{Ag}$ (fig. C-1).

7 Omar-Epigenetic replacement deposits of Paleozoic age; include bedded barite occurrences. Grab samples contain $15.3 \% \mathrm{Cu}, 0.15 \% \mathrm{~Pb}, 0.95 \% \mathrm{Zn}, 0.05 \% \mathrm{Co}$, and $0.3 \mathrm{oz} /$ ton $\mathrm{Ag}$. BLM estimates 35 million tons of $4 \% \mathrm{Cu}$ (fig. $\mathrm{C}-1$ ).

7a Frost-Possible 9 million tons of barite in pods, lenses, and wavy-banded quartz-calcite-barite veins.
Chalcopyrite and galena occur in veins which cross cut Paleozoic limestone and dolomite for a minimum distance of $1 \mathrm{mi}$. Selected samples contain up to 13.2\% Zn (fig. C-1).

8 Bornite-Major stratabound $\mathrm{Cu}-\mathrm{Zn}$ deposit in brecciated carbonate rock of Devonian age; 5.0 million ton orebody contains $4.0 \% \mathrm{Cu}$ and accessory $\mathrm{Zn}$ and Co. Larger reserve estimate of 40 million tons of about $2 \% \mathrm{Cu}$ and undisclosed amount of $\mathrm{Zn}$ and $\mathrm{Co}$. At grade of $1.2 \% \mathrm{Cu}$, reserves are 100 million tons (fig. C-1).

9 Arctic-Major volcanogenic $(\mathrm{Cu}-\mathrm{Zn})$ massive sulfide deposit hosted in sequence of metarhyolite, metatuff, and graphitic schist of Devonian age; indicated reserves of 40 million tons grade $4.0 \% \mathrm{Cu}, 5.5 \% \mathrm{Zn}$, $0.8 \% \mathrm{~Pb}, 1.6 \mathrm{oz} /$ ton $\mathrm{Ag}$, and $0.02 \mathrm{oz} /$ ton $\mathrm{Au}$ (fig. C-1).

$10 \mathrm{Sun}$-Major $(\mathrm{Cu}-\mathrm{Pb}-\mathrm{Zn}-\mathrm{Ag})$ massive sulfide deposit in sequence of middle Paleozoic metarhyolite and metabasalt. Average grades are 1 to $4 \% \mathrm{~Pb}, 6$ to $12 \%$ $\mathrm{Zn}, 0.5$ to $7 \% \mathrm{Cu}, 3$ to $11 \mathrm{oz} / \mathrm{ton} \mathrm{Ag}$ (fig. C-1).

11 Smucker-Middle Paleozoic volcanogenic massive sulfide deposit; 3,000 ft long and up to $190 \mathrm{ft}$ wide; 


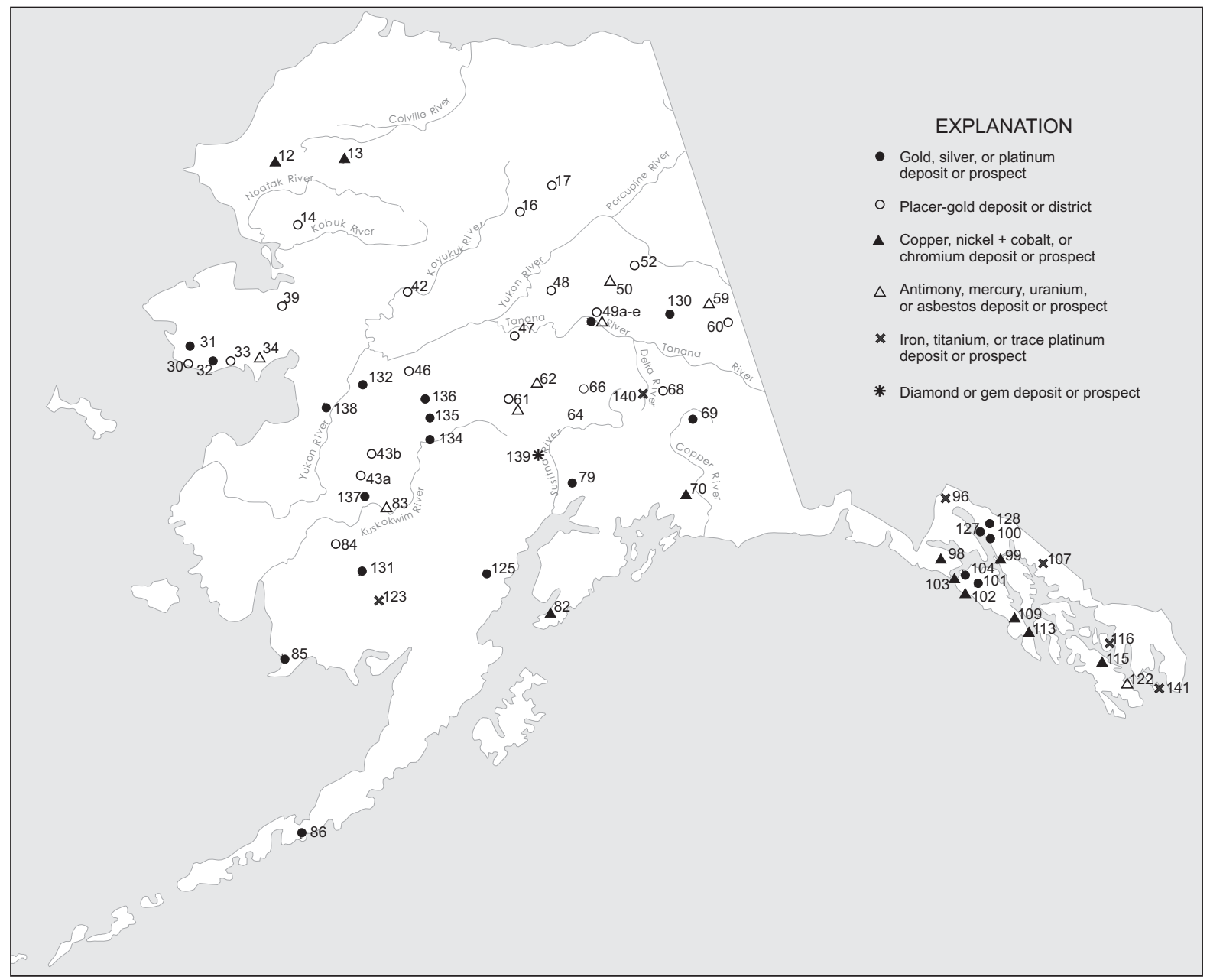

Figure C-3. Significant gold, silver, platinum, and strategic mineral deposits in Alaska, 2009.

contains significant tonnage of $\mathrm{Cu}-\mathrm{Pb}-\mathrm{Zn}$ ore that grades $1.5 \% \mathrm{~Pb}, 5$ to $10 \% \mathrm{Zn}, 3$ to $10 \mathrm{oz} /$ ton $\mathrm{Ag}$, with minor Au (fig. C-1).

12 Avan Hills - Disseminated chromite in layered ultramafic rocks; grab samples contain up to $4.3 \% \mathrm{Cr}$ with $0.015 \mathrm{oz} /$ ton PGM (fig. C-3).

13 Misheguk Mountain - Chromite occurrences similar to those in Avan Hills (fig. C-3).

14 Klery Creek-Lode and placer Au deposits worked intermittently from 1909 through 1930s. Total production through 1931, mostly from placer deposits, estimated at 31,320 oz Au (fig. C-3).

15 Ernie Lake (Ann Creek) - Stratabound massive sulfide occurrence in metarhyolite, metatuff, and marble.

Gossan zones strongly anomalous in $\mathrm{Cu}-\mathrm{Pb}-\mathrm{Zn}$ and Ag (fig. C-1).

16 Koyukuk mining district-Major placer Au district; from 1893 to 2006 produced an estimated $347,661 \mathrm{oz}$ $\mathrm{Au}$. Gold placers in Nolan Creek mined on surface and underground, both sources of large gold nuggets. Significant deep placer reserves remain (fig. C-3).
17 Chandalar mining district-Major Au-producing district; substantial production in excess of $66,287 \mathrm{oz}$ Au through 2006 from lode and placer sources; lode $\mathrm{Au}$ found in crosscutting quartz veins that intrude schist and greenstone. Active development of placer deposits and lodes in progress. Inferred lode reserves estimated to be 45,000 tons with grade of $2 \mathrm{oz} /$ ton $\mathrm{Au}$ (fig. C-3).

18 Porcupine Lake - Stratiform fluorite occurrences and argentiferous enargite, tetrahedrite associated with felsic volcanic rocks of late Paleozoic age. Reported grades of up to $30 \%$ fluorite $\left(\mathrm{CaF}_{2}\right)$ reported, with grab samples of $4.8 \% \mathrm{Cu}$ (fig. $\mathrm{C}-2$ ).

19 Wind River - Stratabound $\mathrm{Pb}-\mathrm{Zn}$ massive sulfide prospects; reported grades of up to $5 \% \mathrm{~Pb}$ (fig. C-1).

20 Esotuk Glacier-Disseminated Mo-Sn-W-Pb-Zn mineralization in skarns associated with Devonian(?) schistose quartz monzonite. Grab samples contain up to $0.08 \% \mathrm{Sn}$ and $0.15 \% \mathrm{~W}$ (fig. C-2).

21 Bear Mountain-Major stockwork Mo-W-Sn occurrence in intrusive breccia. Rock samples containing up to $0.8 \%$ Mo and $0.6 \% \mathrm{~W}$ occur within a 35-acre area where soil samples average more than 
$0.2 \% \mathrm{MoS} 2$, and an adjacent 25 -acre area where rubble contains wolframite has soils averaging greater than $0.12 \% \mathrm{WO}$. Rubble crop in this area indicates a Tertiary porphyry system as the source of the Mo and W (fig. C-2).

21a Galena Creek-Steeply dipping veins contain up to $21 \% \mathrm{Cu}, 3.5 \% \mathrm{Zn}$, and $1.3 \% \mathrm{~Pb}$ with $5.5 \mathrm{oz} /$ ton $\mathrm{Ag}$ on the east side of the creek, and on the ridge west of the creek a large area of disseminated mineralization and veinlets contains predominantly Zn (fig. C-1).

22 Cape Creek-Major placer Sn producer. More than 500 tons Sn produced from 1935 to 1941; from 1979 to 1990 , produced 1,040 tons Sn. Derived from Cape Mountain in contact zone of Cretaceous granite and limestone (fig. C-2).

23 Buck Creek-Major placer Sn producer. More than 1,100 tons Sn produced from 1902 to 1953 (fig. C-2).

24 Lost River-Major Sn, fluorite, W, and Be deposit associated with Cretaceous Sn granite system. More than 350 tons $\mathrm{Sn}$ produced from skarn and greisen lode sources. Measured reserves amount to 24.6 million tons that grade $0.15 \% \mathrm{Sn}, 16.3 \% \mathrm{CaF} 2$, and $0.03 \% \mathrm{WO}$, based on $45,000 \mathrm{ft}$ of diamond drilling (fig. C-2).

25 Ear Mountain - Placer Sn district and $\mathrm{Sn}-\mathrm{Cu}-\mathrm{Au}-$ $\mathrm{Ag}-\mathrm{Pb}-\mathrm{Zn}$ skarn mineralization of Cretaceous age. Area also anomalous in U (fig. C-2).

26 Kougarok Mountain - Sn deposit hosted in quartztourmaline-topaz greisen of Cretaceous age. Grades may average $0.5 \% \mathrm{Sn}$ and $0.01 \% \mathrm{Ta}$ and $\mathrm{Nb}$, but a high-grade resource of 150,000 tons grading $1 \%+\mathrm{Sn}$ was identified, with incrementally higher tonnage at lower grades (fig. C-2).

27 Hannum - Stratiform, carbonate-hosted $\mathrm{Pb}-\mathrm{Zn}-\mathrm{Ag}$ massive sulfide deposit of mid-Paleozoic age in heavily oxidized zone that ranges from 30 to $150 \mathrm{ft}$ thick. Mineralized zone reported to assay up to $10 \%$ $\mathrm{Pb}, 2.2 \% \mathrm{Zn}, 0.04 \mathrm{oz} /$ ton $\mathrm{Au}$, and $1.76 \mathrm{oz} /$ ton $\mathrm{Ag}$ (fig. C-1).

28 Independence Creek- $\mathrm{Pb}-\mathrm{Zn}-\mathrm{Ag}$ massive sulfide deposit; high-grade ore shipped in 1921 contained $30 \% \mathrm{~Pb}, 5 \% \mathrm{Zn}$, up to $150 \mathrm{oz} / \mathrm{ton} \mathrm{Ag}$. Mineralization restricted to shear zone in carbonates (fig. C-1).

29 Sinuk River region - Several $\mathrm{Pb}-\mathrm{Zn}-\mathrm{Ag}-\mathrm{Ba}-\mathrm{F}$ bearing massive sulfide deposits and layered $\mathrm{Fe}$ deposits in carbonate and metavolcanic rocks of Nome Group. Mineralized zones extend for over $8,000 \mathrm{ft}$ along strike (fig. C-1).

30 Nome mining district-Major placer $\mathrm{Au}$ producer. Production from 1897-2006 in excess of 4,998,886 oz Au, all from placers. Past $\mathrm{Sb}$ and $\mathrm{W}$ production (fig. C-3).

31 Rock Creek-550,000 oz Au resource, with about 11.79 million tons grading $0.059 \mathrm{oz} /$ ton $\mathrm{Au}$ in vein swarms and stringers in an area 1,500 ft long, $500 \mathrm{ft}$ maximum width and $300 \mathrm{ft}$ deep (fig. C-3).

32 Big Hurrah-Epigenetic vein deposit in black slate and metasedimentary rocks of the Solomon schist. Deposit contains some W mineralization and has produced over 27,000 oz Au from nearly 50,000 tons milled ore. Proven, inferred, and indicated reserves total 104,000 tons that grade $0.61 \mathrm{oz} /$ ton $\mathrm{Au}, 0.55$ oz/ton Ag, and credits of $\mathrm{WO}_{3}$ (fig. C-3).

33 Solomon and Council mining districts-Major placer Au districts; produced over 1,046,522 oz through 2006. Three structurally controlled $\mathrm{Au}$ deposits in Bluff area-Daniels Creek, Saddle, and Koyana Creek - contain minimum inferred reserves of 6.5 million tons grading $0.1 \mathrm{oz} /$ ton $\mathrm{Au}$ (fig. C-3).

34a Eagle Creek-U prospect in Cretaceous Kachauik alkalic intrusive rocks. Highly anomalous $\mathrm{U}$ concentrations up to 1,000 ppm reported (fig. C-3).

34b Death Valley (Boulder Creek) - Sandstonetype $U$ prospect with predominantly epigenetic mineralization. Over 11,000 feet of drilling defined a minimum reserve of 1 million pounds of $\mathrm{U}_{3} \mathrm{O}_{8}$ with average grade of $0.27 \% \mathrm{U}_{3} \mathrm{O}_{8}$ and 9.9 foot thickness within 200 feet of surface (fig. C-3).

35 Omalik - Vein-type $\mathrm{Pb}-\mathrm{Zn}-\mathrm{Ag}$ massive sulfide prospect in Paleozoic carbonate rocks; from 1881 to 1900 , produced 400 tons of $\mathrm{Pb}-\mathrm{Zn}$ ore that averaged about $10 \% \mathrm{~Pb}$ and $40 \mathrm{oz} /$ ton $\mathrm{Ag}$. Grades of oxidized $\mathrm{Zn}$ ore reported to be up to $34 \% \mathrm{Zn}$ (fig. C-1).

36 Windy Creek-Disseminated $\mathrm{Mo}-\mathrm{Pb}-\mathrm{Zn}$ mineralization in quartz veins and skarn with reported values as high as $0.15 \%$ Mo (fig. C-2).

37 Quartz Creek-Significant $\mathrm{Pb}-\mathrm{Zn}-\mathrm{Ag}$ mineralization; reported grades of $15 \%$ combined $\mathrm{Pb}-\mathrm{Zn}$ and $10 \mathrm{oz} /$ ton $\mathrm{Ag}$ (fig. C-1).

38 Peace River-Significant Mo-F mineralization disseminated in intrusive rocks. Reported values of $0.2 \%$ Mo (fig. C-2).

39 Fairhaven/Inmachuk district-Placer deposits with 348,924 oz production from 1902-2006; significant reserves remaining in a large ancestral channel system. Large base metal sulfide concentrations and $U$ values in concentrates (fig. C-3).

40 Poovookpuk Mountain - Porphyry Mo mineralization. Reported grades of up to $0.25 \% \mathrm{Mo}$ (fig. C-2).

41 Purcell Mountain-Mo and Ag occurrences associated with Cretaceous alkalic igneous plutons, alaskite, and bostonite dikes (fig. C-2).

42 Hughes mining district-Production of $289,104 \mathrm{oz}$ $\mathrm{Au}$ from 1930 to 2006, mainly from Alaska Gold Co. dredge at Hogatza; dredge reactivated in 1981, but deactivated in 1984, and reactivated again in 1990. Non-float mechanized operation on Utopia Creek produced significant amount of placer Au from 1930 to 1962 (fig. C-3).

43 Iditarod district-Major placer Au district; produced 1,563,459 oz Au through 2006. Significant reserves of lode $\mathrm{Au}$ and lode $\mathrm{W}$ at Golden Horn deposit Chicken Mountain, and other known lodes in region associated with shear zones and monzonite intrusive rocks of Late Cretaceous age (fig. C-3).

44 Innoko-Tolstoi mining district-Major placer $\mathrm{Au}$ district with significant lode $\mathrm{Au}-\mathrm{Sb}-\mathrm{Hg}$ potential; lode sources are Late Cretaceous volcanic-plutonic complexes and dike swarms that intrude Mesozoic 
flysch; mining district produced 732,353 oz Au through 2006, almost all from placer deposits (fig. C-3).

45 Bonanza Creek-Skarn-type W mineralization along intrusive contact; no published information available (fig. C-2).

46 Ruby mining district-Placer $\mathrm{Au}-\mathrm{Sn}$ district; produced more than 477,976 oz Au from 1931 to 2006; mining district also contains $\mathrm{Pb}-\mathrm{Ag}$ prospects with grades reportedly as high as $82 \mathrm{oz} /$ ton $\mathrm{Ag}$ (fig. C-3).

47 Hot Springs mining district $-\mathrm{Placer} \mathrm{Au}-\mathrm{Sn}$ district; produced more than 582,620 oz Au and over 720,000 lb cassiterite through 2006. Includes Eureka and Tofty subdistricts. Magnetite-rich, niobium-bearing carbonatite sill in the Tofty area contains geochemically anomalous $\mathrm{Nb}, \mathrm{REE}, \mathrm{P}$, and $\mathrm{Y}$ (figs. C-2, C-3).

48 Tolovana mining district-Placer $\mathrm{Au}$ district; produced more than 529,573 oz Au since discovery in 1914 to 2006. Substantial reserves remain mainly on Livengood Bench, a Pliocene ancestral channel (fig. C-3).

49 Fairbanks mining district-Nationally ranked $\mathrm{Au}$-producing district; largest producer in Alaska. Produced about 8,197,458 oz Au from placer deposits (1902-2006). Major lode Au and lode Sb producer; produced more than 4,094,196 oz Au and over 2000 tons $\mathrm{Sb}$ from veins and shear zones through 2006. Production of W exceeded 4,000 short ton units since 1915, all derived from skarn near Cretaceous quartz monzonite (fig. C-3).

49a Fort Knox-Disseminated $\mathrm{Au}$ deposit within granodiorite/quartz monzonite pluton near Fairbanks. Proven and probable reserves as of December 31, 2006 , open at depth, are 2,705,000 oz of $\mathrm{Au}$ in 176.0 million tons of rock at an average Au grade of 0.015 oz/ton. Measured and indicated resources are 70.69 million tons grading $0.018 \mathrm{oz} /$ ton Au containing $1,289,000$ ounces of gold, with 1,573,000 ounces of measured and indicated gold resources in the Fort Knox area. Fairbanks Gold Mining Inc. at Fort Knox and True North mines produced 3,676,284 oz of $\mathrm{Au}$ from 1996 to 2006 (fig. C-3).

49b Ryan Lode - Based on a 0.015 oz/ton cutoff, total reserves in the metasediment-hosted Ryan Lode and subparallel igneous-hosted Curlew Shear are 822,200 $\mathrm{oz}$ of $\mathrm{Au}$ in 14.6 million tons of rock. A geologic resource of about 2.4 million oz occurs within the total shear zone system (fig. C-3).

49c Grant Mine - Series of subparallel Au-bearing quartz veins in schist and quartzite of Ester Dome based on exploration in 1990. Indicated reserves one of the O'Dea vein system are 212,000 tons of $0.36 \mathrm{oz} /$ ton $\mathrm{Au}$. Other similar vein systems are found nearby (fig. C-3).

49d True North-Au occurs in siderite-quartz veins in carbonaceous quartzite and schist within a terrane containing eclogitic rocks. An indicated resource of $188,000 \mathrm{oz} \mathrm{Au}$ at grade of $0.040 \mathrm{oz} /$ ton $\mathrm{Au}$ in
4,665,000 tons of rock as of December 31, 2006. 11.04 million tons of $0.04 \mathrm{oz} /$ ton ore were processed at Fort Knox mill from 2001 through 2004 (fig. C-3).

49e Dolphin-Mineralized intermediate intrusion contains anomalous $\mathrm{Au}, \mathrm{As}, \mathrm{Bi}$ and $\mathrm{Sb}$. Discovery hole in 1995 intercepted $330 \mathrm{ft}$ of $0.049 \mathrm{oz} /$ ton Au (fig. C-3).

49f Gil Claims - Gold occurs in two calc-silicate zones within Paleozoic schist units. Gold enrichment occurs along iron-stained shears and within quartz-calcite veinlets. Drilling identified an in-place $\mathrm{Au}$ resource of $433,000 \mathrm{oz}$ at an average grade of $0.04 \mathrm{oz} / \mathrm{ton} \mathrm{Au}$ (fig. C-3).

50 Mt. Prindle - Significant U-rare-earth mineralization in Mesozoic alkaline igneous rocks. Rock geochemical values of up to $0.7 \% \mathrm{U}$; up to $15 \%$ rare-earth elements reported (fig. C-3).

51 Twin Mountain - Significant W mineralization associated with skarn development along contact zone of quartz monzonite stock of Cretaceous age (fig. C-2).

52 Circle mining district - Currently one of Alaska's largest producing placer $\mathrm{Au}$ districts; produced more than $1,068,860 \mathrm{oz}$ Au since discovery in 1893 to 2006. Has significant potential for $\mathrm{Sn}, \mathrm{W}$, and $\mathrm{Au}$ mineralization from variety of lode sources (fig. C-3).

53 Three Castle Mountain, Pleasant Creek, Casca VABM - Stratabound $\mathrm{Pb}-\mathrm{Zn}$ massive sulfide mineralization. Reported grades of up to $17 \% \mathrm{Zn}$ and $2 \% \mathrm{~Pb}$ (fig. C- 1 ).

54 Bonnifield district massive sulfide deposits (Anderson Mountain, Dry Creek, Sheep Creek, Virginia Creek, BT, Liberty Bell) - Significant volcanogenic $\mathrm{Cu}-\mathrm{Pb}-\mathrm{Zn}-\mathrm{Ag}$ massive sulfide deposits of Devonian to Mississippian age. Potential for high-grade deposits reported. Includes Liberty Bell stratabound $\mathrm{Au}-\mathrm{B}$ deposit and mineralization in Sheep Creek; latter contains $\mathrm{Sn}$ as well as base metals (fig. C-1).

55 Delta massive sulfide belt - Contains at least 30 known volcanogenic massive sulfide deposits and occurrences. Grades from 0.3 to $1.1 \% \mathrm{Cu}, 1.7$ to $5.7 \%$ $\mathrm{Zn}, 0.5$ to $2.3 \% \mathrm{~Pb}, 0.7$ to $2.0 \mathrm{oz} /$ ton $\mathrm{Ag}$, and 0.018 to $0.061 \mathrm{oz} /$ ton $\mathrm{Au}$; estimated potential reserve of 40 million tons for all deposits. Recent exploration has identified several gold prospects associated with silicified structures in the White Gold trend (fig. C-1).

56 Mosquito, Peternie - Porphyry Mo prospects of early Tertiary age; reported grades of up to $0.17 \% \mathrm{Mo}$ (fig. C-2).

57 Taurus - Significant major porphyry $\mathrm{Cu}-\mathrm{Au}$ prospect of Paleocene age. East Taurus Zone contains inferred reserves of 140 million tons grading about $0.30 \% \mathrm{Cu}$ and $0.01 \mathrm{oz} /$ ton $\mathrm{Au}$, and $0.03 \% \mathrm{Mo}$ (fig. C-2).

58 Big Creek/Ladue - Stratabound $\mathrm{Pb}-\mathrm{Zn}-\mathrm{Ag}$ massive sulfide prospects in metavolcanic rocks (fig. C-1).

59 Slate Creek-At least 55 million tons of $6.3 \%$, highquality chrysotile asbestos in serpentinized ultramafic rocks of Permian(?) age (fig. C-3).

60 Fortymile mining district-Major placer $\mathrm{Au}$ district. Produced over 561,646 oz placer and very minor 
lode Au since discovery in 1883 to 2006 , the longest continuous production of $\mathrm{Au}$ (120 years) of any Alaskan mining district (fig. C-3).

61 Kantishna mining district-Major placer $\mathrm{Au}$ and lode $\mathrm{Ag}-\mathrm{Au}-\mathrm{Pb}-\mathrm{Zn}-\mathrm{Sb}-\mathrm{W}$ district. Produced 99,307 oz placer and lode $\mathrm{Au}$, about 307,000 oz lode Ag, and 2,500 tons $\mathrm{Sb}$ from shear zones and vein deposits hosted in metamorphic units of Yukon-Tanana terrane. Nearly 90 lode deposits have been identified; potential exists for significant $\mathrm{Ag}-\mathrm{Au}-\mathrm{Pb}-\mathrm{Zn}$ resources. Metalliferous stratabound base metal deposits occur in schist and quartzite (fig. C-3).

62 Stampede mine-Major Sb deposit; produced more than 1,750 tons $\mathrm{Sb}$ from large shear zone in poly-metamorphic rocks of Yukon-Tanana terrane (fig. C-3).

63 Coal Creek-Greisen-hosted $\mathrm{Sn}-\mathrm{Cu}-\mathrm{W}$ deposit in "McKinley" age pluton (55 million years old). Reported reserves of 5 million tons of ore that grade $0.28 \% \mathrm{Sn}$ and $0.3 \% \mathrm{Cu}$ with credits of $\mathrm{W}, \mathrm{Ag}$, and $\mathrm{Zn}$ (fig. C-2).

64 Golden Zone mine-Major $\mathrm{Au}-\mathrm{Cu}-\mathrm{Ag}$ deposits in Late Cretaceous breccia pipe and skarn deposits. Produced more than 1,581 oz Au, 8,617 oz Ag, and 21 tons $\mathrm{Cu}$. The Golden Zone deposit contains measured and indicated resources of approximately 2 million tons, grading $0.106 \mathrm{oz} /$ ton $\mathrm{Au}, 0.47 \mathrm{oz} /$ ton $\mathrm{Ag}$ and $0.12 \% \mathrm{Cu}$ (utilizing a $0.05 \mathrm{oz} /$ ton Au cut-off grade), and contains approximately 214,800 ounces of gold, 948,000 ounces of silver and 24,000 pounds of copper. (figs. C-1, C-3).

65 Nim Prospect-Porphyry $\mathrm{Cu}-\mathrm{Ag}-\mathrm{Au}$ deposit of Late Cretaceous age. Reported grades of up to $5.0 \% \mathrm{Cu}$ and 9 oz/ton Ag (fig. C-1).

66 Valdez Creek district-About 513,671 oz Au production through 2006. Cambior Alaska Inc., the largest placer mine in Alaska, operated in this district until September 1995 (fig. C-3).

67 Caribou Dome (Denali) - Ten identified stratabound $\mathrm{Cu}$ deposits in volcanic sedimentary rocks of Triassic age. Proven and probable ore is 700,000 tons grading $6 \% \mathrm{Cu}$ with $\mathrm{Ag}$ credits, with indicated resources that may contain 2 million tons ore over strike length of 4,000 feet (fig. C-1).

67a Zackly-Disseminated $\mathrm{Cu}$ and $\mathrm{Au}$ in garnet-pyroxene skarn and marble. Reserves are estimated at 1.4 million tons grading 2.6 percent $\mathrm{Cu}$ and $0.175 \mathrm{oz} /$ ton $\mathrm{Au}$ (fig. C-1).

68 Chistochina-Porphyry $\mathrm{Cu}$ prospects of Tertiary age and placer Au district; produced more than $182,719 \mathrm{oz}$ $\mathrm{Au}$ and small amount $\mathrm{Pt}$ from placer deposits through 2006 (figs. C-2, C-3).

69 Nabesna mine - Classic high-grade Au skarn that envelopes quartz diorite of Jurassic(?) age; produced over 66,500 oz Au from about 88,000 tons of ore from 1930 to 1941 (fig. C-3).

70 Spirit Mountain-Massive and disseminated $\mathrm{Cu}-\mathrm{Ni}$ mineralization in mafic-ultramafic complex (fig. C-3).

71 Kennecott deposits-Major stratiform $\mathrm{Cu}-\mathrm{Ag}$ massive sulfide deposits localized near contact between Chitistone Limestone and Nikolai Greenstone of Triassic age; contained some of highest grade $\mathrm{Cu}$ lodes mined in North America. From 1911 to 1938, produced more than 600,000 tons $\mathrm{Cu}$ and 10 million oz Ag from 4.8 million tons ore. Some reserves remain (fig. C-1).

72 Binocular and other prospects - Kennecott-type $\mathrm{Cu}-\mathrm{Ag}$ massive sulfide deposits (fig. $\mathrm{C}-1$ ).

73 Bond Creek-Orange Hill-Two major porphyry $\mathrm{Cu}-\mathrm{Mo}$ deposits of Late Cretaceous age; reported inferred reserves of 850 million tons ore that grade 0.3 to $0.5 \% \mathrm{Cu}$ and $0.03 \% \mathrm{Mo}$ (fig. C-2).

74 Carl Creek-Porphyry $\mathrm{Cu}$ prospect in altered intrusive complex; similar to locality 73 (fig. C-2).

75 Baultoff-Porphyry $\mathrm{Cu}$ prospect in altered intrusive rocks; inferred reserves of 145 million tons of $0.20 \%$ $\mathrm{Cu}$; similar to locality 73 (fig. C-2).

76 Horsfeld - Porphyry $\mathrm{Cu}$ prospect of Late Cretaceous age (fig. C-2).

77 Midas mine - Significant stratabound $\mathrm{Cu}(\mathrm{Ag}-$ $\mathrm{Au}-\mathrm{Pb}-\mathrm{Zn}$ ) massive sulfide deposit in volcanic sedimentary rocks of Tertiary Orca Group. Produced more than 1,650 tons $\mathrm{Cu}$ from 49,350 tons ore (fig. C-1).

78 Ellamar-Stratabound $\mathrm{Cu}-\mathrm{Zn}-\mathrm{Au}$ massive sulfide deposit in sediment of Eocene(?) Orca Group. Produced more than 8,000 tons $\mathrm{Cu}, 51,307 \mathrm{oz} \mathrm{Au}$, and $191,615 \mathrm{oz} \mathrm{Ag}$ from about 301,835 tons ore (fig. C-1).

79 Willow Creek, Independence, Lucky Shot, War Baby-Major lode $\mathrm{Au}$ deposits ( $\mathrm{Ag}-\mathrm{Cu}-\mathrm{Pb}-\mathrm{Zn}-\mathrm{Mo}$ ) in veins cutting Mesozoic quartz diorite. Produced more than 606,400 oz Au from lode sources and about 55,600 oz Au from associated placer deposits (fig. C-3).

80 Latouche, Beatson-Major stratabound $\mathrm{Cu}-\mathrm{Zn}-\mathrm{Ag}$ massive sulfide deposits in Orca Group sedimentary rocks and mafic volcanic rocks. Produced more than 10,250 tons $\mathrm{Cu}$ from 6 million tons ore. Inferred reserves of 5 million tons ore that grade $1 \% \mathrm{Cu}, 1.5 \%$ $\mathrm{Pb}+\mathrm{Zn}$ (fig. C-1).

81 Rua Cove-Major stratabound $\mathrm{Cu}-\mathrm{Zn}$ massive sulfide deposit in complex ore shoots enclosed in mafic volcanic rocks of Orca Group. Reported reserves of over 1.1 million tons ore that grade $1.25 \% \mathrm{Cu}$ (fig. C-1).

82 Red Mountain and Claim Point-Significant Cr occurrences associated with Jurassic layered ultramafic complexes at Red Mountain near Seldovia. More than 39,951 tons of metallurgical-grade ore shipped through 1976; huge low-grade $\mathrm{Cr}$ resource may remain, of which 30 million tons grade $5.1 \%$ $\mathrm{Cr}_{2} \mathrm{O} 3$ (fig. C-3).

83 Red Devil-Major Hg-Sb deposit; high-grade epithermal $\mathrm{Hg}-\mathrm{Sb}$ deposit hosted in shear zones in Kuskokwim Group sedimentary rocks. More than 35,000 flasks $\mathrm{Hg}$ produced from 75,000 tons ore (fig. C-3).

84 Aniak district - Significant placer Au district with 595,366 oz Au produced through 2006, mainly from the Nyac and Donlin Creek areas (fig. C-3). 
85 Goodnews Bay-Major placer Pt district; estimated to have produced over 555,000 oz refined PGE metals from 1934 to 1976; one of the largest known PGE metal resources in United States. Possible resources of 60 million yd 3 of deep, PGE-bearing gravels remain. Lode source believed to be Alaskan-type zoned ultramafic complex of Jurassic or Cretaceous age. Possible significant offshore placer potential (fig. C-3).

86 Apollo-Sitka mines - Major lode Au deposits; produced more than $107,600 \mathrm{oz} \mathrm{Au}$ from ore that averaged about $0.22 \mathrm{oz} /$ ton $\mathrm{Au}$. Inferred reserves are 748,000 tons grading $0.76 \mathrm{oz} /$ ton $\mathrm{Au}, 2.16 \mathrm{oz} /$ ton $\mathrm{Ag}$, with base metal credits (fig. C-3).

87 Pyramid-Late Tertiary porphyry $\mathrm{Cu}-\mathrm{Mo}$ deposit; inferred reserves of 125 million tons ore that grade $0.4 \% \mathrm{Cu}$ and $0.03 \%$ Mo reported (fig. C-2).

88 Ivanof-Late Tertiary porphyry $\mathrm{Cu}$ prospect; grades of up to $0.72 \% \mathrm{Cu}$ reported. Potential for large tonnages (fig. C-2).

89 Weasel Mountain, Bee Creek-Porphyry $\mathrm{Cu}-\mathrm{Mo}$ prospect of late Tertiary to Quaternary age; grades of up to $0.48 \% \mathrm{Cu}$ and $0.035 \%$ Mo reported. Potential for moderate tonnages of low-grade mineralization (fig. C-2).

90 Mike deposit - Porphyry Mo prospect of late Tertiary age; grades up to $0.21 \%$ Mo. Potential for large tonnages of low-grade Mo mineralization (fig. C-2).

91 Rex deposit - Porphyry $\mathrm{Cu}$ prospect similar to locality 90; grades up to $0.3 \% \mathrm{Cu}$. Potential for moderate reserves of low-grade mineralization (fig. C-2).

92 Kasna Creek-Major stratiform $\mathrm{Cu}-\mathrm{Pb}-\mathrm{Zn}$ and skarn-sulfide deposits of Mesozoic age in mafic, volcanic, and sedimentary rocks; reported reserves of over 10 million tons ore that grade more than $1 \% \mathrm{Cu}$ (fig. C-1).

93 Sleitat Mountain - High-grade east-west-trending, $\mathrm{Sn}-\mathrm{W}-\mathrm{Ag}$ topaz-quartz greisen system hosted in 59-million-year-old granite and in hornfels. Zone up to 3,000 ft long and $500 \mathrm{ft}$ wide. One drill-hole with $85 \mathrm{ft}$ of $1.8 \% \mathrm{Sn}$, and $0.4 \% \mathrm{~W}$. Inferred resources up to 106,000 tons $\mathrm{Sn}$ in 29 million tons ore (fig. C-2).

94 Jimmy Lake - Complex $\mathrm{Cu}-\mathrm{Ag}-\mathrm{Sn}$ mineralization of late Tertiary(?) age; reported grades of up to 105 oz/ton $\mathrm{Ag}$ and $3 \% \mathrm{Cu}$ (fig. C-1).

95 Haines Barite/Palmer-Major stratiform $\mathrm{Ba}-\mathrm{Pb}-\mathrm{Zn}$ $\mathrm{Cu}-\mathrm{Ag}$ deposit in pillow basalt-dominated section of Paleozoic or Triassic age; consists of 48 - to 60 -ft-thick zone of $60 \%$ barite with upper zone ( 2 to $8 \mathrm{ft}$ thick) of massive sulfides that contain $2 \% \mathrm{~Pb}, 3 \% \mathrm{Zn}, 1 \% \mathrm{Cu}$, up to $4 \mathrm{oz} /$ ton $\mathrm{Ag}$, and $0.12 \mathrm{oz} /$ ton $\mathrm{Au}$. Estimated to contain 750,000 tons of $65 \%$ barite with $\mathrm{Zn}$ and $\mathrm{Ag}$ credits (fig. C-1).

96 Klukwan-Major Fe-Ti deposits in zoned ultramafic complex of Mesozoic age; reported to contain 3 billion tons of material grading $16.8 \% \mathrm{Fe}$ and 1.6 to $3.0 \% \mathrm{Ti}$ (fig. C-3).

97 Nunatak - Porphyry Mo deposit; reported reserves of 2.24 million tons ore grading $0.067 \% \mathrm{Mo}, 0.16 \%$ $\mathrm{Cu}$, and 129.5 million tons of $0.026 \% \mathrm{Mo}, 0.18 \% \mathrm{Cu}$ (fig. C-2).
98 Brady Glacier-Major Ni-Cu deposit in layered gabbro-pyroxenite complex of Tertiary age. Proven reserves of 100 million tons ore that grade $0.5 \% \mathrm{Ni}$, $0.3 \% \mathrm{Cu}$ reported and about $0.03 \% \mathrm{Co}$; also contains PGE concentrations (fig. C-3).

99 Mertie Lode and Funter Bay - Contains substantial reserves of lode Au mineralization. Past production totaled about 15,000 oz Au. Deposits also contain significant $\mathrm{Ni}-\mathrm{Cu}$ and $\mathrm{Pb}-\mathrm{Zn}-\mathrm{Ag}$ mineralization. Funter Bay deposit contains reported reserves of 560,000 tons that grade $0.34 \% \mathrm{Ni}, 0.35 \% \mathrm{Cu}$, and $0.15 \%$ Co in gabbro-pipe system (fig. C-3).

100 Alaska-Juneau-Major lode Au deposit that consists of 100- to 300-ft-wide zone that contains en echelon, $\mathrm{Au}$-bearing quartz veins in metamorphic rocks; produced more than 3.52 million oz Au from 88.5 million tons ore from 1893 to 1944. Reserves (all categories) of 105.7 million tons of $0.05 \mathrm{oz} /$ ton $\mathrm{Au}$ (fig. C-3).

101 Chichagof and Hirst Chichagof-Major lode $\mathrm{Au}$ deposits in quartz veins that cut Mesozoic graywacke; produced more than $770,000 \mathrm{oz} \mathrm{Au}$, most of which was produced at Chichagof Mine. Inferred leased reserves estimated to be $100,000 \mathrm{oz} \mathrm{Au}$ (fig. C-3).

102 Mirror Harbor- $-\mathrm{Ni}-\mathrm{Cu}$ mineralization in layered gabbro complex of Mesozoic age; reported proven reserves of 8,000 tons of $1.57 \% \mathrm{Ni}$ and $0.88 \% \mathrm{Cu}$ and reported inferred reserves of several million tons ore that grade $0.2 \% \mathrm{Ni}$ and $0.1 \% \mathrm{Cu}$ (fig. C-3).

103 Bohemia Basin-Major Ni-Cu-Co mineralization in layered mafic complex similar to locality 102 ; reported reserves of 22 million tons ore that grade 0.33 to $0.51 \% \mathrm{Ni}, 0.21$ to $0.27 \% \mathrm{Cu}$, and $0.02 \% \mathrm{Co}$, all of which are recoverable with standard flotation technology (fig. C-3).

104 Apex-EI Nido - Significant lode $\mathrm{Au}-\mathrm{W}$ deposits occurring as cross-cutting veins in graywacke; produced more than 50,000 oz Au (fig. C-3).

105 Greens Creek-Major sediment-hosted $\mathrm{Pb}-\mathrm{Zn}$ $\mathrm{Cu}-\mathrm{Ag}-\mathrm{Au}$ volcanogenic massive sulfide deposit of Devonian or Triassic age. Production from 1989 to 1993 and 1996 to 2006 is 989,769 tons of $\mathrm{Zn}, 302,493$ tons of $\mathrm{Pb}$, over 8,600 tons of $\mathrm{Cu}, 135.4$ million oz of $\mathrm{Ag}$, and $982,216 \mathrm{oz}$ of $\mathrm{Au} .2006$ probable reserve estimate is 7.68 million tons grading $10.39 \% \mathrm{Zn}$, $3.98 \% \mathrm{~Pb}, 14.42 \mathrm{oz} /$ ton $\mathrm{Ag}$, and $0.113 \mathrm{oz} /$ ton $\mathrm{Au}$. Inferred resources are 5.07 million tons grading $10.4 \%$ $\mathrm{Zn}, 4.0 \% \mathrm{~Pb}, 0.113 \mathrm{oz} /$ ton $\mathrm{Au}$, and $14.42 \mathrm{oz} /$ ton $\mathrm{Ag}$. (fig. C-1).

106 Sumdum - Volcanogenic $\mathrm{Cu}-\mathrm{Pb}-\mathrm{Zn}$ massive sulfide deposit in Mesozoic metamorphic complex with potential strike length of over 10,000 ft. Inferred reserves of 26.7 million tons ore that grade $0.57 \% \mathrm{Cu}$, $0.37 \% \mathrm{Zn}$, and $0.3 \mathrm{oz} /$ ton $\mathrm{Ag}$ reported (fig. C-1).

107 Snettisham-Fe-Ti deposit in mafic zoned intrusive complex; reported grades of about $18.9 \% \mathrm{Fe}$ and $2.6 \%$ Ti (fig. C-3).

108 Tracy Arm - Stratabound $\mathrm{Cu}-\mathrm{Zn}-\mathrm{Pb}$ massive sulfide prospect in Mesozoic schist; over 1,100 ft long and up to $12 \mathrm{ft}$ thick. Reported grades of $1.5 \% \mathrm{Cu}, 3.9 \% \mathrm{Zn}$, $0.76 \mathrm{oz} / \mathrm{ton} \mathrm{Ag}$, and $0.013 \mathrm{oz} /$ ton $\mathrm{Au}$ (fig. C-1). 
109 Red Bluff Bay-Significant chrome mineralization in Mesozoic ultramafic complex (probably ophiolite); reported reserves of 570 tons of material that grade $40 \% \mathrm{Cr}$ and 29,000 tons that grade 18 to $35 \% \mathrm{Cr}$ (fig. C-3).

110 Cornwallis Peninsula-Volcanogenic $\mathrm{Cu}-\mathrm{Pb}-\mathrm{Zn}-$ $\mathrm{Ag}-\mathrm{Ba}$ massive sulfide deposit of Triassic(?) age; reported grades of up to $20 \% \mathrm{~Pb}-\mathrm{Zn}$ and $23 \mathrm{oz} / \mathrm{ton} \mathrm{Ag}$ (fig. C-1).

111 Castle Island - Stratiform barite deposit of Triassic age hosted in carbonate and pillow basalt; about 856,000 tons of raw and refined barite produced from 1963 to 1980; also contains $\mathrm{Zn}, \mathrm{Pb}$, and $\mathrm{Cu}$ sulfides. Reported to be mined out (fig. C-1).

112 Groundhog Basin - Area with several massive sulfide prospects in Mesozoic schist and gneiss whose origins are possibly plutonic associated. Reported grades of up to $8 \% \mathrm{~Pb}, 29 \mathrm{oz} /$ ton $\mathrm{Ag}$, and $0.5 \mathrm{oz} /$ ton $\mathrm{Au}$. Sn has also been recently identified. Area also contains potential for porphyry Mo deposits (fig. C-1).

113 Snipe Bay-Ni-Cu deposit in zoned mafic-ultramafic complex; inferred reserves of 430,000 tons of $0.3 \%$ $\mathrm{Ni}, 0.3 \% \mathrm{Cu}$, and $0.13 \mathrm{oz} / \mathrm{ton} \mathrm{Ag}$ reported (fig. C-3).

114 Kasaan Peninsula-Major skarn-type $\mathrm{Cu}-\mathrm{Fe}-\mathrm{Au}$ massive sulfide deposit of Jurassic age; area has produced over 14,000 tons $\mathrm{Cu}$, and 55,000 oz Ag. Reported reserves of 4 million tons ore that grade $50 \%$ $\mathrm{Fe}$ and less than $2 \% \mathrm{Cu}$ (fig. C-1).

115 Salt Chuck- $\mathrm{Cu}-\mathrm{PGM}-\mathrm{Ag}-\mathrm{Au}$ deposit in contact zone between pyroxenite and gabbro within Alaskantype zoned mafic-ultramafic pluton. From 1900 to 1941, 2,500 tons $\mathrm{Cu}$, over 20,000 oz PGM, and $\mathrm{Au}$ and $\mathrm{Ag}$ credits were produced from 325,000 tons ore (fig. C-3).

116 Union Bay-Significant Fe-Ti-(V) mineralization in zoned, Ural-Alaska type ultramafic complex At least 7 zones of PGE-magnetite hydrothermal mineralization associated with pyroxene veins that crosscut magmatic layering (fig. C-3).

117 Hyder mining district-Area produced more than 25,000 tons high-grade $\mathrm{W}-\mathrm{Cu}-\mathrm{Pb}-\mathrm{Zn}-\mathrm{Ag}$ ore from 1925 to 1951 from crosscutting ore shoots in Texas Creek granodiorite of Tertiary age. Area contains potential for porphyry Mo-W mineralization and massive sulfide-skarn $\mathrm{Pb}-\mathrm{Ag}-\mathrm{Au}-\mathrm{W}$ deposits (figs. C-1, C-2).

118 Jumbo - $\mathrm{Cu}-\mathrm{Fe}-\mathrm{Mo}-\mathrm{Ag}$ skarn deposit; produced more than 5,000 tons $\mathrm{Cu}, 280,000 \mathrm{oz} \mathrm{Ag}$, and 7,000 oz Au from 125,000 tons ore. Zoned magnetite- $\mathrm{Cu}$ skarns are associated with epizonal granodiorite pluton of Cretaceous age. Reported reserves of 650,000 tons ore that grade $45.2 \% \mathrm{Fe}, 0.75 \% \mathrm{Cu}, 0.01 \mathrm{oz} /$ ton $\mathrm{Au}$, and $0.08 \mathrm{oz} /$ ton $\mathrm{Ag}$ (fig. C-1).

119 Copper City-Stratiform $\mathrm{Cu}-\mathrm{Zn}-\mathrm{Ag}-\mathrm{Au}$ massive sulfide deposit in late Precambrian or earliest Paleozoic Wales Group. Reported grades of up to $12.7 \% \mathrm{Cu}, 2.7 \% \mathrm{Zn}, 2.5 \mathrm{oz} / \mathrm{ton} \mathrm{Ag}$, and $0.2 \mathrm{oz} /$ ton $\mathrm{Au}$ (fig. C-1).

120 Quartz Hill - A porphyry Mo deposit hosted in a 25-million-year-old composite felsic pluton. Probable reserves are 232 million tons with a grade of $0.22 \%$ $\mathrm{MoS} 2$, and possible reserves are 1.2 billion tons with $0.12 \% \mathrm{MoS} 2$ (fig. C-2).

121 Niblack-Volcanogenic $\mathrm{Cu}-\mathrm{Pb}-\mathrm{Au}-\mathrm{Ag}$ massive sulfide deposit hosted in Precambrian(?) Wales Group or Ordovician to Silurian Descon Formation; produced more than 700 tons $\mathrm{Cu}, 11,000 \mathrm{oz} \mathrm{Au}$, and 15,000 oz Ag. Resource of 2.78 million tons at $3.22 \% \mathrm{Zn}, 1.70 \%$ $\mathrm{Cu}, 0.93 \mathrm{oz} /$ ton $\mathrm{Ag}$ and $0.081 \mathrm{oz} / \mathrm{ton} \mathrm{Au}$. (fig. C-1).

122 Bokan Mountain-Numerous U-Th prospects associated with Jurassic peralkaline intrusive complex; from 1955 to 1971 , produced more than 120,000 tons ore that graded about $1 \% \mathrm{U}_{3} \mathrm{O} 8$. Contains inferred reserves of about 40 million tons of $0.126 \% \mathrm{Nb}$ and up to $1 \%$ REE metals (fig. C-3).

123 Kemuk Mountain-Magmatic Fe-Ti deposit hosted in Cretaceous(?) pyroxenite. Inferred reserves of 2.4 billion tons that average 15 to $17 \% \mathrm{Fe}, 2$ to $3 \% \mathrm{TiO} 2$, and $0.16 \% \mathrm{P}_{2} \mathrm{O} 5$ (fig. C-3).

124 McLeod-Porphyry Mo deposit that contains quartzmolybdenite fissure veins in quartz-feldspar porphyry. Chip samples contain up to $0.09 \%$ Mo (fig. C-2).

125 Johnson River-Epigenetic(?) quartz-sulfide stockwork or massive sulfide deposit hosted in volcaniclastic, pyroclastic, and volcanic rocks of Jurassic Talkeetna Formation. Deposit has drilledout reserves at a $\$ 45 /$ ton cutoff with no cut of high $\mathrm{Au}$ assays, 1,099,580 tons grading $0.32 \mathrm{oz} /$ ton $\mathrm{Au}$, $0.24 \mathrm{oz} /$ ton $\mathrm{Ag}, 0.76 \% \mathrm{Cu}, 1.17 \% \mathrm{~Pb}$, and $8.37 \% \mathrm{Zn}$ (fig. C-3).

126 Nimiuktuk River - Small hill of massive, high-grade barite estimated to contain at least 1.5 million tons barite. Widespread stream-sediment $\mathrm{Ba}$ anomalies in area indicate further barite potential (fig. C-1).

127 Kensington-Stockwork quartz veins in sheared and chloritized quartz diorite produced 10,900 tons grading $0.18 \mathrm{oz} /$ ton Au prior to 1930. Recent estimates indicate at least 4.42 million tons grading $0.31 \mathrm{oz} /$ ton $\mathrm{Au}$ for 1,352,140 oz Au of proven and probable reserves and 4.32 million tons of mineralized material grading $0.20 \mathrm{oz} /$ ton $\mathrm{Au}$ (fig. C-3).

128 Jualin-Five quartz-fissure veins in Cretaceous quartz diorite, more than $15,000 \mathrm{ft}$ of underground workings; produced 48,387 oz Au, mainly prior to 1930 . Reserves included in the reserves of the Kensington property (fig. C-3).

129 Pebble (Copper) - One of the world's largest $\mathrm{Cu}-\mathrm{Au}$ porphyry deposits with several known centers. The Pebble West deposit has a measured, indicated and inferred resource of 2.04 billion tons grading $0.34 \%$ $\mathrm{Cu}, 0.011 \mathrm{oz} /$ ton $\mathrm{Au}$ and $0.018 \% \mathrm{Mo}$ at a $0.50 \% \mathrm{Cu}$ equivalent cutoff. The new Pebble East deposit has an inferred resource of 3.75 billion tons grading $0.57 \%$ $\mathrm{Cu}, 0.011 \mathrm{oz} /$ ton $\mathrm{Au}$ and $0.036 \% \mathrm{Mo}$ at a $0.60 \%$ $\mathrm{Cu}$ equivalent cutoff. The 2007 combined resource contains 67 billion pounds of copper, 82 million ounces of gold and 5.2 billion pounds of molybdenum. Mineralized system extends over 35 square mile area and includes other $\mathrm{Cu}-\mathrm{Au}-\mathrm{Mo}$ porphyry, $\mathrm{Cu}-\mathrm{Au}$ skarn, and Au vein prospects (fig. C-1). 
130 Pogo - Au hosted in at least three sub-parallel and tabular, gently dipping, quartz vein zones hosted by Paleozoic gneisses intruded by Cretaceous felsic plutonic rocks. Au in the $3 \mathrm{ft}$ to $60 \mathrm{ft}$ thick quartz bodies has a strong correlation with $\mathrm{Bi}$. A mining reserve for the Liese L1 and L2 zones is 7.7 million tons at an average grade of $0.47 \mathrm{oz} / \mathrm{ton}$, for a total of 3.63 million oz at a $0.1 \mathrm{oz} /$ ton cut-off grade. Produced 113,364 ounces of gold in 2006. Other high-grade $\mathrm{Au}$ targets have been identified along an 8-mi-long trend southeast of the Liese zones (fig. C-3).

131 Shotgun - Quartz stockwork and breccia $\mathrm{Au}-\mathrm{Cu}-\mathrm{As}$ mineralization in a Late Cretaceous rhyolite (granite porphyry) stock. A preliminary, inferred Au resource of 980,000 oz (36.11 million tons at an average grade of $0.027 \mathrm{oz} /$ ton $\mathrm{Au}$ ) at a $0.016 \mathrm{oz} /$ ton Au cut-off grade, with initial metallurgical tests indicating $>90 \% \mathrm{Au}$ recovery by cyanide leaching (fig. $\mathrm{C}-3$ ).

132 Illinois Creek- $\mathrm{Au}-\mathrm{Ag}-\mathrm{Cu}-\mathrm{Pb}-\mathrm{Zn}-\mathrm{Bi}-\mathrm{As}$-bearing, $\mathrm{Fe}-\mathrm{Mn}$ oxide (gossan) shear zone crosscutting dolomitic quartzite localized near Cretaceous granitic pluton. Shear zone averaged $148 \mathrm{ft}$ wide, with a drilldefined east-west strike length of 11,600 ft. Produced approximately 143,860 oz Au and 755,600 oz Ag from 1997 to 2004. Past ore grade of $0.076 \mathrm{oz} /$ ton $\mathrm{Au}$ and $1.6 \mathrm{oz} /$ ton Ag (figs. C-1, C-3).

133 Calder Mine - Seven recrystallized carbonate units exposed at the apex of a large regional antiform. Drilling has identified 13 million tons of chemically homogenous, high-brightness, high-whiteness marble with a purity of 98 to $99 \%$ calcium carbonate. Potential resource of 80 million tons of high-value calcium carbonate (fig. C-2).

134 Vinasale Mountain-Intrusion-hosted $\mathrm{Au}$ deposit. $\mathrm{Au}$ occurs as disseminated and veinlet mineralization, with arsenopyrite and pyrite in quartz-dolomite hydrothermal breccias, magmatic breccias, and zones of phyllic and silicic alteration hosted within a $69 \mathrm{Ma}$ quartz monzonite stock. Inferred resource of 14.35 million tons grading $0.067 \mathrm{oz} /$ ton $\mathrm{Au}$, with an $0.03 \mathrm{oz} /$ ton cut-off grade was for the Central zone (fig. C-3).

135 Nixon Fork-Au-Cu skarn deposits; Historic Nixon Fork mine produced 59,500 oz Au from Late Cretaceous skarns associated with quartz monzoniteDevonian limestone contact zones. Underground mining resumed in October 1995, with 137,748 oz of $\mathrm{Au}, 1,050$ tons of $\mathrm{Cu}$, and significant $\mathrm{Ag}$ produced through mine closure in 1999. 2006 ore resources and reserves are 25,787 tons grading $1.07 \mathrm{oz} /$ ton
$\mathrm{Au}$ (measured), 138,852 tons grading $0.63 \mathrm{oz} / \mathrm{ton}$ (indicated), and 102,486 tons grading $0.45 \mathrm{oz} /$ ton (inferred), with proven reserves of 51,800 tons grading $0.993 \mathrm{oz} /$ ton $\mathrm{Au}$ and probable reserves of 151,600 tons grading $0.54 \mathrm{oz} /$ ton $\mathrm{Au}$, for a total of 295,430 ounces of gold (fig. C-3). .

136 Von Frank Mountain-Au and very weak $\mathrm{Cu}$ mineralization are associated with chalcopyrite, pyrite, and rare molybdenite within a zone of quartz stockwork veining hosted in a 69 Ma quartz-diorite stock. The stock is a cupola of the larger Von Frank Pluton. Drill intercepts include up to $429 \mathrm{ft}$ wide with an average grade of $0.013 \mathrm{oz} /$ ton Au. Higher-grade intercepts include $0.035 \mathrm{oz} /$ ton $\mathrm{Au}$ up to $135 \mathrm{ft}$ (fig. C-3).

137 Donlin Creek-Au mineralization associated with disseminated pyrite and arsenopyrite, sulfide veinlets, and quartz-carbonate-sulfide veinlets in sericite-altered Late Cretaceous to early Tertiary rhyodacitic porphyry dikes and sills. Au mineralization is structurally controlled, refractory, and occurs along a 4-mile long, 1-mile wide zone. 2006 measured and indicated resource estimated at 16.6 million oz of Au grading $0.070 \mathrm{oz} /$ ton $\mathrm{Au}$ and an inferred resource of 17.1 million oz Au grading $0.068 \mathrm{oz} /$ ton $\mathrm{Au}$ at a $0.022 \mathrm{oz} /$ ton Au cut-off grade. Considered the 25th largest gold resource in the world (fig. C-3).

138 Kaiyah-Au-Ag epithermal prospect in silicified Koyukuk sedimentary rocks adjacent to Poison Creek caldera. Polymetallic sulfides in quartz veins, with some veins over 100 feet thick, and silicification are associated with pervasive advanced argillic, and sericite alteration (fig. C-3).

139 Shulin Lake - Micro-and macro-diamonds occur in interbedded volcaniclastic and tuffaceous rocks containing olivine and pyroxene. Discovered by tracing diamond indicator minerals in placer gravels. Possibly lamproitic intrusions with up to 1-mile diameter circular aeromagnetic anomalies (fig. C-3).

140 Canwell and Nikolai Complex-Ni-Cu-PGE semimassive to massive sulfide prospects hosted in mafic and ultramafic rocks of the Nikolai intrusive/extrusive complex. Five mafic-ultramafic intrusions in the central Alaska Range are comagmatic with the Nikolai flood basalts (fig. C-3).

141 Duke Island - $\mathrm{Cu}-\mathrm{Ni}-\mathrm{PGE}$ disseminated, semimassive, and massive sulfides associated with 2 zoned, Ural-Alaska type ultramafic bodies (fig. C-3). 


\section{Appendix D \\ Companies and individuals reported to be producing metal in Alaska, 2009}

\begin{tabular}{|c|c|c|c|}
\hline Operator & Creek or Mine & District & Type $^{\text {a }}$ \\
\hline \multicolumn{4}{|c|}{ NORTHERN REGION } \\
\hline Barry Lambeth and Dave Burrow & Hammond River & Koyukuk-Nolan & $\mathrm{O} / \mathrm{P}$ Placer \\
\hline Boreal Resources Inc./Eric Pyne & California Creek, Jim Pup & Koyukuk-Nolan & $\mathrm{O} / \mathrm{P}$ Placer \\
\hline $\begin{array}{l}\text { BREXCO Brooks Range Exploration } \\
\text { Company Inc. (and Tod Bauer, } \\
\text { Operator) }\end{array}$ & Lake Creek & Koyukuk-Nolan & $\mathrm{O} / \mathrm{P}$ Placer \\
\hline Brian Yoder & Sheep Creek & Koyukuk-Nolan & $\mathrm{O} / \mathrm{P}$ Placer \\
\hline Compass Mining Inc./John Hall & Linda Creek & Koyukuk-Nolan & $\mathrm{O} / \mathrm{P}$ Placer \\
\hline D.M.V.G. Ventures/Michael Fischer & Prospect Creek & Koyukuk-Nolan & $\mathrm{O} / \mathrm{P}$ Placer \\
\hline Daniel Even and Matthew Even & $\begin{array}{l}\text { Gold Basin Creek, Webster } \\
\text { Gulch }\end{array}$ & Koyukuk-Nolan & $\mathrm{O} / \mathrm{P}$ Placer \\
\hline Glen DeFord & Smally Creek & Koyukuk-Nolan & $\mathrm{S} / \mathrm{D}$ - Recreation \\
\hline Goldrich Mining Company & Various & Chandalar & $\mathrm{O} / \mathrm{P}$ Placer \\
\hline Goldrich Mining Company & Little Squaw Creek & Chandalar & $\mathrm{O} / \mathrm{P}$ Placer \\
\hline James and Lorna Lounsbury & Union Gulch & Koyukuk-Nolan & $\mathrm{O} / \mathrm{P}$ Placer \\
\hline James Wicken & Gold Basin Creek & Koyukuk-Nolan & $\mathrm{O} / \mathrm{P}$ Placer \\
\hline Joe Annagulles & S. Fork Koyukuk River & Koyukuk-Nolan & $\mathrm{O} / \mathrm{P}$ Placer \\
\hline John and Christy Perkins & Marion Creek & Koyukuk-Nolan & $\mathrm{O} / \mathrm{P}$ Placer \\
\hline Larry Weisz & Hammond River & Koyukuk-Nolan & $\begin{array}{l}\text { O/P Placer and } \\
\text { S/D - Recreation }\end{array}$ \\
\hline Lee and Tom Crawford & Glacier Creek & Koyukuk-Nolan & $\mathrm{O} / \mathrm{P}$ Placer \\
\hline Lloyd Swenson & Slate Creek & Koyukuk-Nolan & $\mathrm{O} / \mathrm{P}$ Placer \\
\hline Mike Dobson & Near Prospect Creek & Koyukuk-Nolan & O/P Placer \\
\hline Northern Lights Mining Inc./Ben Batty & Rye Creek, Jay Creek & Koyukuk-Nolan & $\mathrm{S} / \mathrm{D}$ - Recreation \\
\hline Paradise Valley Inc./Mick Manns & $\begin{array}{l}\text { Birch Creek, Flat Creek, Agnes } \\
\text { Creek, Oregon Creek }\end{array}$ & Koyukuk-Nolan & $\begin{array}{l}\text { O/P Placer and } \\
\text { S/D - Recreation }\end{array}$ \\
\hline Q4M Production Company & Marion Creek & Koyukuk-Nolan & $\mathrm{O} / \mathrm{P}$ Placer \\
\hline Richard Wright & $\begin{array}{l}\text { Magnet Creek, Gold Basin } \\
\text { Creek }\end{array}$ & Koyukuk-Nolan & $\mathrm{O} / \mathrm{P}$ Placer \\
\hline Rick Conklin & Boulder Creek & Koyukuk-Nolan & $\mathrm{O} / \mathrm{P}$ Placer \\
\hline Slisco Inc./Ralph Hamm & $\begin{array}{l}\text { Hammond River, Swift Creek, } \\
\text { Marion Creek }\end{array}$ & Koyukuk-Nolan & $\mathrm{O} / \mathrm{P}$ Placer \\
\hline Stewart Brandon & Myrtle Creek & Koyukuk-Nolan & O/P Placer \\
\hline Teck Cominco Alaska Inc. & Red Dog Mine & Lisburne & $\mathrm{O} / \mathrm{P} \mathrm{HR}$ \\
\hline William Nordeen & Emma Creek & Koyukuk-Nolan & $\begin{array}{l}\mathrm{O} / \mathrm{P} \text { Placer and } \\
\text { S/D - Recreation }\end{array}$ \\
\hline
\end{tabular}

Alfred Johnson

Alvin Hanson

Anderson \& Sons Mining/Ralph Anderson

Andrew Lee and Robert Hehnlin Beaton Path Mining LLC/Tim Beaton

$\begin{array}{ll}\text { Byron Henshaw } & \text { Boob Creek } \\ \text { Craig Coggins } & \text { Norton Sound } \\ \text { Daniel Martinson } & \text { Near Anvil Creek } \\ \text { Daniel Murphy } & \text { Norton Sound } \\ \text { Daryl Galipeau } & \text { Norton Sound } \\ \text { David McCully } & \text { Bering Sea }\end{array}$

Norton Sound

\section{WESTERN REGION}

Norton Sound

Boulder Creek

$\mathrm{n} / \mathrm{a}$

Norton Sound

Nugget Creek, Wilson Creek

Boob Creek

Norton Sound

Bering Sea

\section{Cape Nome \\ Council-Solomon \\ Cape Nome}

Cape Nome

Gold Hill-Melozitna

Innoko-Tolstoi-

Ophir

Cape Nome

Cape Nome

Cape Nome

Cape Nome

Cape Nome
$\mathrm{S} / \mathrm{D}$ - Large

$\mathrm{O} / \mathrm{P}$ Placer and S/D

$\mathrm{O} / \mathrm{P}$ Placer

S/D - Large

O/P Placer and placer exploration O/P Placer

S/D - Large O/P Placer S/D - Large S/D - Recreation S/D - Large

${ }^{\mathrm{a}} \mathrm{O} / \mathrm{P}=$ Open pit; $\mathrm{HR}=$ Hardrock; $\mathrm{U} / \mathrm{G}=$ Underground; $\mathrm{S} / \mathrm{D}=$ Suction Dredge; Large - Greater than or equal to an 8" nozzle. $\mathrm{S} / \mathrm{D}-$ Recreation $=$ small suction dredge and recreational operations. Prepared from a list of permitted operations; not all produced during the year. 


\begin{tabular}{|c|c|c|c|}
\hline Operator & Creek or Mine & District & Type \\
\hline Donal Mullikin & Windy Creek, Garfield Creek & Kougarok & O/P Placer \\
\hline Frank McFarland & Bering Sea & Cape Nome & $\mathrm{S} / \mathrm{D}$ - Large \\
\hline Gene Brown and Scott Foster & Norton Sound & Cape Nome & $\mathrm{S} / \mathrm{D}$ - Large \\
\hline $\begin{array}{l}\text { Gold Prospectors Association of } \\
\text { America/Ken Rucher }\end{array}$ & Nome area & Cape Nome & $\mathrm{S} / \mathrm{D}-$ Recreation \\
\hline Jan Kralik & Bering Sea & Cape Nome & $\mathrm{S} / \mathrm{D}$ - Large \\
\hline Jan Kralik & Gold Run & Cape Nome & $\mathrm{S} / \mathrm{D}$ - Recreation \\
\hline Jan Siks and Jim Hatadis & $\begin{array}{l}\text { Davis Creek, tributary of South } \\
\text { Fork Koyukuk River }\end{array}$ & Koyukuk-Hughes & $\mathrm{S} / \mathrm{D}-$ Recreation \\
\hline Jerry Landgrebe & Cape Nome & Cape Nome & $\mathrm{S} / \mathrm{D}$ - Large \\
\hline Joey Comoza & Norton Sound & Cape Nome & $\mathrm{S} / \mathrm{D}$ - Large \\
\hline John Mehelich & Norton Sound & Cape Nome & $\mathrm{S} / \mathrm{D}$ - Large \\
\hline K \& S Leasing, Inc./Norman Stiles & Nome Offshore & Cape Nome & $\mathrm{S} / \mathrm{D}$ - Large \\
\hline Kenneth Takak & Ungalik River, Tubutulik River & Koyuk & S/D - Recreation \\
\hline Little Creek Mine/Paul Sayer & Bedrock Creek & $\begin{array}{l}\text { Innoko-Tolstoi- } \\
\text { Ophir }\end{array}$ & $\mathrm{O} / \mathrm{P}$ Placer \\
\hline Lonnie Fausett & Norton Sound & Cape Nome & $\mathrm{S} / \mathrm{D}-$ Recreation \\
\hline MacIsh Mining, LLC/Ronald MacLaren & Chapman Creek & Koyukuk-Hughes & $\mathrm{O} / \mathrm{P}$ Placer \\
\hline Mark Gumaer & Dick Creek & Serpentine & O/P Placer \\
\hline Mark West & Norton Sound & Cape Nome & $\mathrm{S} / \mathrm{D}$ - Recreation \\
\hline Mike Gibson and Wayne Gibson & Golden Creek, Gay Creek & Gold Hill-Melozitna & $\mathrm{O} / \mathrm{P}$ Placer \\
\hline N.B. Tweet \& Sons, LLC/N.B. Tweet & Kougarok River & Kougarok & $\mathrm{O} / \mathrm{P}$ Placer \\
\hline Neil Rosander & Cripple Creek & $\begin{array}{l}\text { Innoko-Tolstoi- } \\
\text { Ophir }\end{array}$ & $\mathrm{O} / \mathrm{P}$ Placer \\
\hline Nome Alaska Gold Concentrates & Anvil Creel & Cape Nome & $\mathrm{O} / \mathrm{P}$ Placer \\
\hline $\begin{array}{l}\text { Ocean View Gravels, Inc. Alaska Entity } \\
\quad \# 115542\end{array}$ & $\mathrm{n} / \mathrm{a}$ & Cape Nome & $\mathrm{O} / \mathrm{P}$ Placer \\
\hline $\begin{array}{l}\text { Peckenpaugh Mining Inc./Jon } \\
\text { Peckenpaugh }\end{array}$ & West Branch Sherrette Creek & Council & $\mathrm{O} / \mathrm{P}$ Placer \\
\hline Randy Sowell & Norton Sound & Cape Nome & $\mathrm{S} / \mathrm{D}$ - Large \\
\hline Richard Markley & Norton Sound & Cape Nome & $\mathrm{O} / \mathrm{P}$ Placer \\
\hline Richard Redmong & Macklin Creek & Kougarok & $\mathrm{O} / \mathrm{P}$ Placer and $\mathrm{S} / \mathrm{D}$ \\
\hline Samuel "Kelly" Thomas & Sweepstakes Creek & Koyuk & $\mathrm{O} / \mathrm{P}$ Placer \\
\hline Sona Holdings Co./Evan Morse & Bering Sea/Cape Nome & Cape Nome & $\mathrm{S} / \mathrm{D}$ - Large \\
\hline Steve Phillips & Norton Sound/Bering Sea & Cape Nome & S/D - Recreation \\
\hline Steve Pomrenke & Martin Creek & Cape Nome & $\mathrm{O} / \mathrm{P}$ Placer \\
\hline Strategic Materials/Les Cobb & Quartz Creek & Kougarok & $\mathrm{O} / \mathrm{P}$ Placer \\
\hline Taiga Mining Company Inc./Jerry Birch & Aloha Creek, Clear Creek & Koyukuk-Hughes & $\mathrm{O} / \mathrm{P}$ Placer \\
\hline Thomas Blake & Dome Creek & Kougarok & $\mathrm{O} / \mathrm{P}$ Placer \\
\hline Thomas Stamps & Norton Sound & Cape Nome & $\mathrm{S} / \mathrm{D}$ - Large \\
\hline Tom Massie and Blake Harmon & Arctic Creek & Cape Nome & $\begin{array}{l}\mathrm{S} / \mathrm{D} \text { - Large and } \\
\mathrm{S} / \mathrm{D}-\text { Recreation }\end{array}$ \\
\hline Victor Loyer & Near Candle Creek & Fairhaven & O/P Placer \\
\hline Wesley DeVore & Norton Sound & Cape Nome & $\mathrm{S} / \mathrm{D}$ - Large \\
\hline
\end{tabular}

\begin{tabular}{|c|c|c|c|}
\hline \multicolumn{4}{|c|}{ EASTERN INTERIOR REGION } \\
\hline A. J. Davis & Cherry Creek & Fortymile & $\mathrm{O} / \mathrm{P}$ Placer \\
\hline AK Team GS LLC & Uhler Creek & Fortymile & $\mathrm{O} / \mathrm{P}$ Placer \\
\hline Andy Miscovich & Wolf Creek & Fairbanks & $\mathrm{O} / \mathrm{P}$ Placer \\
\hline Arctic Mining LLC/Morris Wolters & Crooked Creek & Circle & $\mathrm{O} / \mathrm{P}$ Placer \\
\hline Bruce Herning & Palmer Creek & Fairbanks & S/D - Recreation \\
\hline C.J. Hill & Lost Chicken Creek & Fortymile & $\mathrm{O} / \mathrm{P}$ Placer \\
\hline $\begin{array}{l}\text { Cascade Gold LLC (operator)/Ronald } \\
\text { Timroth }\end{array}$ & Walker Fork Fortymile River & Fortymile & $\mathrm{O} / \mathrm{P}$ Placer \\
\hline CCR Mining LLC & Mammoth Creek, Stack Pup & Circle & $\mathrm{O} / \mathrm{P}$ Placer \\
\hline Charles "Dick" Hammond & 45 Pup, Chicken & Fortymile & $\mathrm{O} / \mathrm{P}$ Placer \\
\hline Charles Zimmerman & Killarney Creek, Irish Gulch & Hot Springs & $\begin{array}{l}\text { O/P Placer, with use of } \\
\text { S/D for exploration }\end{array}$ \\
\hline Cy Bras & Canyon Creek, Squaw Gulch & Fortymile & $\mathrm{O} / \mathrm{P}$ Placer \\
\hline Dave Eberhardt & Nugget Creek & Fairbanks & $\mathrm{O} / \mathrm{P}$ Placer \\
\hline
\end{tabular}

${ }^{\mathrm{a}} \mathrm{O} / \mathrm{P}=$ Open pit; HR = Hardrock; U/G = Underground; $\mathrm{S} / \mathrm{D}=$ Suction Dredge; Large - Greater than or equal to an 8 " nozzle. $\mathrm{S} / \mathrm{D}-$ Recreation $=$ small suction dredge and recreational operations. Prepared from a list of permitted operations; not all produced during the year. 
Operator

Creek or Mine

District

Type $^{\mathrm{a}}$

\begin{tabular}{|c|c|c|c|}
\hline David Hatch and Sonya Simon & Dome Creek & Fortymile & $\mathrm{O} / \mathrm{P}$ Placer \\
\hline David Jacobs & Moose Creek & Bonnifield & $\mathrm{O} / \mathrm{P}$ Placer \\
\hline David Jacobs & Eva Creek, Wilson Creek & Fairbanks & $\mathrm{O} / \mathrm{P}$ Placer \\
\hline Dean Willis & Crooked Creek & Circle & $\mathrm{O} / \mathrm{P}$ Placer \\
\hline DEPEM/Donald Stein & Gilmore Creek, Tom Creek & Fairbanks & $\mathrm{O} / \mathrm{P}$ Placer \\
\hline Dexter Clark & Fox Creek & Fairbanks & $\mathrm{O} / \mathrm{P}$ Placer \\
\hline Don Kiehl & Gold King Creek & Bonnifield & $\mathrm{O} / \mathrm{P}$ Placer \\
\hline Donald Korte & Clara Creek & Koyukuk-Nolan & $\mathrm{O} / \mathrm{P}$ Placer \\
\hline Donald Smithwick & Crooked Creek & Eagle & $\mathrm{O} / \mathrm{P}$ Placer and S/D \\
\hline Earl Voytilla & Ester Creek & Fairbanks & $\mathrm{O} / \mathrm{P}$ Placer \\
\hline Earth Movers of Fairbanks, Inc. & Fairbanks Creek & Fairbanks & O/P Placer \\
\hline Ed and Willow Salter & Lillian Creek & $\begin{array}{l}\text { Tolovana- } \\
\text { Livengood }\end{array}$ & $\mathrm{O} / \mathrm{P}$ Placer \\
\hline Ed Salter & Alameda Creek & Hot Springs & O/P Placer \\
\hline Elton McGhan & Kal Creek & Fortymile & $\mathrm{O} / \mathrm{P}$ Placer \\
\hline Eric Kile & Woods Creek, Canyon Creek & Fortymile & $\mathrm{O} / \mathrm{P}$ Placer \\
\hline Ernest Johnson & Rhode Island Creek & Hot Springs & $\mathrm{O} / \mathrm{P}$ Placer \\
\hline Fairbanks Gold Mining Inc. & Fort Knox Mine & Fairbanks & $\mathrm{O} / \mathrm{P}$ HR \\
\hline Frank Morrison III & Big Eldorado Creek & Fairbanks & $\mathrm{O} / \mathrm{P}$ Placer \\
\hline Geoquest/Michael Busby & Chicken Creek, Myers Fork & Fortymile & $\mathrm{O} / \mathrm{P}$ Placer \\
\hline Gerald and Kathryn Pitcher & Deadwood Creek & Circle & $\mathrm{S} / \mathrm{D}$ - Recreation \\
\hline Gerald Standefer & Newman Creek & Bonnifield & $\mathrm{O} / \mathrm{P}$ Placer \\
\hline Goldstream Mining LLC & Rhode Island Creek & Hot Springs & O/P Placer \\
\hline Gordon and Judy Olson & Wade Creek & Fortymile & $\mathrm{S} / \mathrm{D}-$ Recreation \\
\hline Hans Sobanja & Rebel Creek & Circle & $\mathrm{O} / \mathrm{P}$ Placer \\
\hline Jackson Mining Company/Roy Traxler & Totatlanika River & Bonnifield & O/P Placer \\
\hline James Dahl & Gold Dust Creek & Circle & $\mathrm{O} / \mathrm{P}$ Placer \\
\hline James Decker & Sheep Creek & Bonnifield & O/P Placer \\
\hline James Kimbro & Fortymile River & Fortymile & $\mathrm{S} / \mathrm{D}$ - Large \\
\hline James Leach III and Annie Leach & Fortymile River & Fortymile & $\mathrm{O} / \mathrm{P}$ Placer \\
\hline James Shriner & Deadwood Creek & Circle & $\mathrm{S} / \mathrm{D}-$ Recreation \\
\hline James Treesh & No name - near Cherry Creek & Fortymile & $\mathrm{O} / \mathrm{P}$ Placer \\
\hline $\begin{array}{l}\text { Jason Minekome, Kenneth Fox, Gerald } \\
\text { Brilke, Ken Fry }\end{array}$ & Walker Fork Fortymile River & Fortymile & $\mathrm{O} / \mathrm{P}$ Placer \\
\hline Jean Turner & Fortymile River & Fortymile & $\mathrm{O} / \mathrm{P}$ Placer \\
\hline Jean Turner and Randy Powelson & Fox Creek & Fairbanks & $\mathrm{O} / \mathrm{P}$ Placer \\
\hline Jeff Owen & Davis Creek & Fortymile & O/P Placer \\
\hline Jeff Owen & Walker Fork Fortymile River & Fortymile & $\mathrm{O} / \mathrm{P}$ Placer \\
\hline Jeffrey and Laura Thimsen & Upper Woods Creek & Fortymile & $\mathrm{O} / \mathrm{P}$ Placer \\
\hline Jerry Hassel & Ready Bullion Creek & Fairbanks & $\mathrm{O} / \mathrm{P}$ Placer \\
\hline Jim Roland & Moose Creek & Bonnifield & $\mathrm{O} / \mathrm{P}$ Placer \\
\hline Jim Roland and Wallace Turner & Moose Creek & Fairbanks & $\mathrm{O} / \mathrm{P}$ Placer \\
\hline Jim Swearingin & Fortymile River & Fortymile & $\mathrm{S} / \mathrm{D}$ - Recreation \\
\hline John and Dawn Lines & North Fork Harrison Creek & Circle & $\mathrm{O} / \mathrm{P}$ Placer \\
\hline Judd Edgerton & Napoleon Creek & Fortymile & O/P Placer \\
\hline Keith Clark & Shamrock Creek & Fairbanks & $\mathrm{O} / \mathrm{P}$ Placer \\
\hline Larry Crouse & Fox Gulch & Fairbanks & O/P Placer \\
\hline Lawrence Ostnes & Totatlanika River & Bonnifield & O/P Placer \\
\hline Leo Regner & Lillywig Creek & Fortymile & O/P Placer \\
\hline Linda Penfield & Slate Creek & Rampart & O/P Placer \\
\hline Mammoth Contracting/Wayne Peppler & Porcupine Creek & Circle & $\mathrm{O} / \mathrm{P}$ Placer \\
\hline Metallogeny & Dome Creek & Fairbanks & O/P Placer \\
\hline Michael Cook & Thistle Creek & Bonnifield & O/P Placer \\
\hline Michael Williams and Guy A. Matthews & McArthur Creek & Fortymile & O/P Placer \\
\hline Mickey Jones and Gary L. Freeland & Mosquito Fork & Fortymile & O/P Placer \\
\hline Miller Creek Mining Co./Fred Wilkinson & Ketchem Creek & Circle & $\mathrm{O} / \mathrm{P}$ Placer \\
\hline $\begin{array}{l}\text { Mudminers, LLC/Timber and Margaret } \\
\text { Wolff }\end{array}$ & Walker Fork Fortymile River & Fortymile & $\mathrm{O} / \mathrm{P}$ Placer \\
\hline Nancy and Harry Dillon & Deadwood Creek & Circle & O/P Placer \\
\hline O.J. Jiles & Gold Bottom Gulch & Koyukuk-Nolan & O/P Placer \\
\hline
\end{tabular}

${ }^{\mathrm{a}} \mathrm{O} / \mathrm{P}=$ Open pit $\mathrm{HR}=$ Hardrock; $\mathrm{U} / \mathrm{G}=$ Underground; $\mathrm{S} / \mathrm{D}=$ Suction Dredge; Large - Greater than or equal to an 8 " nozzle. $\mathrm{S} / \mathrm{D}-$ Recreation $=$ small suction dredge and recreational operations. Prepared from a list of permitted operations; not all produced during the year. 


\begin{tabular}{|c|c|c|c|}
\hline Operator & Creek or Mine & District & Type $^{a}$ \\
\hline Olton Riddles & No Name Creek & Fortymile & O/P Placer \\
\hline Otto and Griswold Stoeppler & Eureka Creek & Hot Springs & $\mathrm{O} / \mathrm{P}$ Placer \\
\hline Paul \& Co./Paul Manuel & Porcupine Creek & Circle & $\mathrm{O} / \mathrm{P}$ Placer \\
\hline Polar Mining/Daniel May & Goldstream Creek & Fairbanks & $\mathrm{O} / \mathrm{P}$ Placer \\
\hline $\begin{array}{l}\text { R \& M Mining/Raymond Lester and } \\
\text { Mike Lester }\end{array}$ & Birch Creek & Circle & $\mathrm{O} / \mathrm{P}$ Placer \\
\hline Raleigh Cline & Eagle Creek & Fortymile & $\mathrm{O} / \mathrm{P}$ Placer \\
\hline Rampart Exploration LLC & $\begin{array}{l}\text { American Creek, Colorado } \\
\text { Gulch }\end{array}$ & Hot Springs & $\mathrm{O} / \mathrm{P}$ Placer \\
\hline Raymond Meder & Flume Creek & Fairbanks & $\mathrm{O} / \mathrm{P}$ Placer \\
\hline Red Olson Mining/Richard Olson & Deadwood Creek & Circle & $\mathrm{O} / \mathrm{P}$ Placer \\
\hline Richard and Wendy Ott & Omega Creek & Hot Springs & $\mathrm{O} / \mathrm{P}$ Placer \\
\hline Richard Loud & $\begin{array}{l}\text { North Fork and South Fork } \\
\text { Harrison Creek }\end{array}$ & Circle & $\mathrm{O} / \mathrm{P}$ Placer \\
\hline Richard Wilder & Little Boulder Creek & Hot Springs & $\mathrm{O} / \mathrm{P}$ Placer \\
\hline Richardson Shield LLC/Alan Las & Smith Creek, Pool Creek & Fairbanks & $\mathrm{O} / \mathrm{P}$ Placer \\
\hline Ricky Nix and Don Sprague & $\begin{array}{l}\text { Mogul Creek, Seventymile } \\
\text { River, Broken Neck Creek }\end{array}$ & Fortymile & $\mathrm{S} / \mathrm{D}$ - Recreation \\
\hline Robert Cook & Gold Dust Creek & Circle & $\mathrm{O} / \mathrm{P}$ Placer \\
\hline Robert Emerson & No stream on property & Fairbanks & $\mathrm{O} / \mathrm{P}$ Placer \\
\hline Robert Hare & Gold Dust Creek & Circle & $\mathrm{O} / \mathrm{P}$ Placer \\
\hline Roberta Brooks & $\begin{array}{l}\text { Mosquito Fork, North Fork, } \\
\text { and South Fork Fortymile } \\
\text { River }\end{array}$ & Fortymile & $\mathrm{S} / \mathrm{D}$ - Recreation \\
\hline Roger Cope & Louis Creek & Fairbanks & O/P Placer \\
\hline Ronald Bergh & $\mathrm{n} / \mathrm{a}$ & Fairbanks & $\mathrm{O} / \mathrm{P}$ Placer \\
\hline Sam and Donna Skidmore & Vault Creek & Fairbanks & Placer exploration \\
\hline Sam Koppenberg & Hunter Creek & Rampart & $\mathrm{O} / \mathrm{P}$ Placer \\
\hline Scott Thomas & Deadwood Creek & Circle & $\mathrm{O} / \mathrm{P}$ Placer \\
\hline $\begin{array}{l}\text { Seuffert Mining Company/George } \\
\text { Seuffert, Jr. }\end{array}$ & Faith Creek & Fairbanks & O/P Placer \\
\hline Sheldon and Janine Maier & Montana Creek & Fortymile & $\mathrm{O} / \mathrm{P}$ Placer \\
\hline Sherlund Mining, LLC/Rick Sherlund & Ketchum Creek & Circle & $\mathrm{O} / \mathrm{P}$ Placer \\
\hline Silver Jim Stroer & Confederate Creek & Fortymile & $\mathrm{O} / \mathrm{P}$ Placer \\
\hline Slate Creek Mining/Steve Adams & Slate Creek & Rampart & O/P Placer \\
\hline Stanley Gelvin & Crooked Creek & Circle & $\mathrm{O} / \mathrm{P}$ Placer \\
\hline Stephen Olson & Liberty Creek & Fortymile & $\mathrm{O} / \mathrm{P}$ Placer \\
\hline Steven Gavora & Fairbanks Creek & Fairbanks & $\mathrm{O} / \mathrm{P}$ Placer \\
\hline Sumitomo Metal Mining Pogo LLC & Pogo Mine & Goodpaster & U/G HR \\
\hline Terry Russell & Trail Creek (Wilder Gulch) & Hot Springs & $\mathrm{O} / \mathrm{P}$ Placer \\
\hline Terry Russell & Boulder Creek & Hot Springs & $\mathrm{O} / \mathrm{P}$ Placer \\
\hline $\begin{array}{l}\text { Tillicum Resources Inc./Fred Cornelius } \\
\text { and Gerald Erickson }\end{array}$ & Fox Creek & Fairbanks & $\mathrm{O} / \mathrm{P}$ Placer \\
\hline Timothy Kelly & North Fork Creek & Hot Springs & $\mathrm{O} / \mathrm{P}$ Placer \\
\hline Timothy Ruppert & Little Moose Creek & Bonnifield & S/D - Recreation \\
\hline TonoGold Resources Inc./Alan Las & No Grub Creek, The Lost Mine & Fairbanks & $\mathrm{O} / \mathrm{P}$ Placer \\
\hline Vernon and Carol Thurneau & Fortymile River & Fortymile & $\mathrm{O} / \mathrm{P}$ Placer \\
\hline $\begin{array}{l}\text { Walter Bohan, William Bohan, Dawn } \\
\text { Miller }\end{array}$ & Ottertail Creek & Fairbanks & $\begin{array}{l}\text { S/D - Large and } \\
\text { S/D - Recreation }\end{array}$ \\
\hline Walter Stockwell & Tenderfoot Creek & Delta River & $\mathrm{O} / \mathrm{P}$ Placer \\
\hline William Aldridge & Poker Creek & Fortymile & $\mathrm{O} / \mathrm{P}$ Placer \\
\hline William Bayless & Franklin Creek & Fortymile & $\mathrm{O} / \mathrm{P}$ Placer \\
\hline $\begin{array}{l}\text { Yello Metal Exploration and Mining/Jack } \\
\text { Barnes }\end{array}$ & Baby Creek, Squaw Gulch & Fortymile & $\mathrm{O} / \mathrm{P}$ Placer and $\mathrm{S} / \mathrm{D}$ \\
\hline \multicolumn{4}{|c|}{ SOUTHCENTRAL REGION } \\
\hline Birch Yuknis & Pass Creek & $\begin{array}{l}\text { Yentna-Cache } \\
\text { Creek }\end{array}$ & $\mathrm{O} / \mathrm{P}$ Placer \\
\hline Brian Berkhahn & Mills Creek & Hope & S/D - Recreation \\
\hline Busch Creek Mining/Dennis Boyce & Busch Creek & Valdez Creek & $\mathrm{O} / \mathrm{P}$ Placer \\
\hline
\end{tabular}




\begin{tabular}{|c|c|c|c|}
\hline Operator & Creek or Mine & District & Type $^{\text {a }}$ \\
\hline C A Gold LLC & Rusty Creek & Valdez Creek & $\mathrm{O} / \mathrm{P}$ Placer \\
\hline Carl Wilbur & Yacko Creek & Nelchina & $\mathrm{O} / \mathrm{P}$ Placer \\
\hline Clearwater Mountain Mining & White Creek & Valdez Creek & $\mathrm{O} / \mathrm{P}$ Placer \\
\hline Crow Creek Mine/Kate Toohey & Crow Creek & Anchorage & S/D - Recreation \\
\hline Daniel Hartman & Cache Creek & $\begin{array}{l}\text { Yentna-Cache } \\
\text { Creek }\end{array}$ & O/P Placer \\
\hline David Burch & Canyon Creek & $\begin{array}{l}\text { Hope-Sunrise \& } \\
\text { Seward }\end{array}$ & $\mathrm{O} / \mathrm{P}$ Placer \\
\hline David Howland & Dry Channel & Chistochina & $\mathrm{O} / \mathrm{P}$ Placer \\
\hline Earle Foster & Wet Gulch & $\begin{array}{l}\text { Willow Creek- } \\
\text { Hatcher Pass }\end{array}$ & S/D - Recreation \\
\hline Fred Wilkes and Robert Bradford & Cache Creek & $\begin{array}{l}\text { Yentna-Cache } \\
\text { Creek }\end{array}$ & $\mathrm{O} / \mathrm{P}$ Placer \\
\hline Fred Wilkes and Robert Bradford & Bird Creek & $\begin{array}{l}\text { Yentna-Cache } \\
\text { Creek }\end{array}$ & $\mathrm{O} / \mathrm{P}$ Placer \\
\hline Gordon Bartel & Mills Creek & $\begin{array}{l}\text { Yentna-Cache } \\
\text { Creek }\end{array}$ & $\begin{array}{l}\text { Placer exploration and } \\
\text { O/P Placer }\end{array}$ \\
\hline Gordon Richmond & Buchia Creek & Valdez Creek & $\mathrm{O} / \mathrm{P}$ Placer \\
\hline Gordon Wolff & Peters Creek & $\begin{array}{l}\text { Yentna-Cache } \\
\text { Creek }\end{array}$ & $\mathrm{O} / \mathrm{P}$ Placer \\
\hline Harold Olson & $\mathrm{n} / \mathrm{a}$ & Willow Creek & $\mathrm{O} / \mathrm{P}$ Placer \\
\hline Jeanard and Brendt Aafedt & Yacko Creek & Nelchina & $\mathrm{O} / \mathrm{P}$ Placer \\
\hline Kenneth and Winona Lee & Cache Creek & $\begin{array}{l}\text { Yentna-Cache } \\
\text { Creek }\end{array}$ & $\begin{array}{l}\text { O/P Placer and } \\
\text { S/D - Recreation }\end{array}$ \\
\hline $\begin{array}{l}\text { Mark Richards, Mark Biggs, and Cree } \\
\text { Biggs }\end{array}$ & $\begin{array}{l}\text { Caribou Creek, Squaw Creek, } \\
\text { Alfred Creek, Jesus Creek, } \\
\text { JehovaJireah Creek }\end{array}$ & $\begin{array}{l}\text { Willow Creek- } \\
\text { Hatcher Pass }\end{array}$ & $\mathrm{S} / \mathrm{D}$ - Large \\
\hline Michael Kingsbury & White Creek & Valdez Creek & $\mathrm{O} / \mathrm{P}$ Placer \\
\hline New Recovery Systems/Estill DeWitt & Alfred Creek & Willow Creek & $\mathrm{S} / \mathrm{D}-3 "$ and $4 "$ dredge \\
\hline $\begin{array}{l}\text { North American Mining LLC/Steve } \\
\text { Sneed }\end{array}$ & $\begin{array}{l}\text { Cottonwood Creek, Willow } \\
\text { Creek, Little Willow Creek }\end{array}$ & $\begin{array}{l}\text { Yentna-Cache } \\
\text { Creek }\end{array}$ & $\mathrm{O} / \mathrm{P}$ Placer \\
\hline Rainbow Mining/Ron Connor & Peters Creek & $\begin{array}{l}\text { Yentna-Cache } \\
\text { Creek }\end{array}$ & $\mathrm{O} / \mathrm{P}$ Placer \\
\hline Samuel Turner & Cache Creek & $\begin{array}{l}\text { Yentna-Cache } \\
\text { Creek }\end{array}$ & $\mathrm{O} / \mathrm{P}$ Placer \\
\hline Steve Sneed & Peters Creek & Yentna & $\mathrm{O} / \mathrm{P}$ Placer \\
\hline Steven Priddle and John Chamberlain & Roosevelt Creek & Valdez Creek & $\mathrm{O} / \mathrm{P}$ Placer \\
\hline Thomas Sternberg & Quartz Creek & $\begin{array}{l}\text { Hope-Sunrise \& } \\
\text { Seward }\end{array}$ & S/D - Recreation \\
\hline Tod Bauer & Dry Creek & $\begin{array}{l}\text { Yentna-Cache } \\
\text { Creek }\end{array}$ & $\mathrm{O} / \mathrm{P}$ Placer \\
\hline Walt Willie & Rusty Creek & Valdez Creek & $\mathrm{O} / \mathrm{P}$ Placer \\
\hline William Stock & White Creek & Valdez Creek & $\mathrm{O} / \mathrm{P}$ Placer \\
\hline
\end{tabular}

\section{SOUTHWESTERN REGION}

Ben Porterfield

Clark-Wiltz Mining Ganes Creek

Recreational/Doug Clark

Daniel Plano

David Wilmarth

Doug Clark

Harry Faulkner
L. E. Wyrick
LeRoy Busk and Richard Busk
Mark Matter
Moore Creek Pay to Mine LLC/Roger
Cowes, Agent
NYAC Mining Co.

Fishhook Creek

Ganes Creek and tributaries

Anvil Creek/Innoko River

George River, Julian Creek

Ganes Creek and tributaries

Ophir Creek
Granite Creek
Syneeva Creek
Marvel Creek
Moore Creek
Shamrock Creek, Bear Creek

McGrath-McKinley

Innoko-TolstoiOphir

Innoko-TolstoiOphir

Aniak-Tuluksak

Innoko-TolstoiOphir

Aniak-Tuluksak

Aniak-Tuluksak

Aniak

Aniak-Tuluksak

Innoko-TolstoiOphir

Aniak-Tuluksak
O/P Placer

S/D - Recreation

O/P Placer

S/D - Large

O/P Placer

O/P Placer

$\mathrm{O} / \mathrm{P}$ Placer

$\mathrm{O} / \mathrm{P}$ Placer

O/P Placer

$\mathrm{O} / \mathrm{P}$ Placer and

S/D - Recreation

${ }^{\mathrm{a}} \mathrm{O} / \mathrm{P}=$ Open pit; HR $=$ Hardrock; $\mathrm{U} / \mathrm{G}=$ Underground; $\mathrm{S} / \mathrm{D}=$ Suction Dredge; Large - Greater than or equal to an $8 "$ nozzle.

$\mathrm{S} / \mathrm{D}-$ Recreation $=$ small suction dredge and recreational operations. Prepared from a list of permitted operations; not all produced during the year. 


\begin{tabular}{|c|c|c|c|}
\hline Operator & Creek or Mine & District & Type $^{\text {a }}$ \\
\hline Randy Sowell & In the ocean & Bethel & $\mathrm{S} / \mathrm{D}$ - Large \\
\hline Rodger Roberts & Ophir Creek & $\begin{array}{l}\text { Innoko-Tolstoi- } \\
\text { Ophir }\end{array}$ & $\mathrm{O} / \mathrm{P}$ Placer \\
\hline Rosander Mining Company Inc. & Colorado Creek & $\begin{array}{l}\text { Innoko-Tolstoi- } \\
\text { Ophir }\end{array}$ & $\mathrm{O} / \mathrm{P}$ Placer \\
\hline Spencer and Carolyn Lyman & Crooked Creek & Iditarod & O/P Placer \\
\hline Strandberg \& Sons/Sigvald Strandberg & $\begin{array}{l}\text { Montana Creek, Creston Creek, } \\
\text { Colorado Creek }\end{array}$ & Innoko & $\mathrm{O} / \mathrm{P}$ Placer \\
\hline XS Platinum Inc. & Salmon River and tributaries & Goodnews Bay & $\mathrm{O} / \mathrm{P}$ Placer \\
\hline \multicolumn{4}{|c|}{ SOUTHEASTERN REGION } \\
\hline Big Nugget Mine/John Schnabel & Porcupine Creek & Porcupine & $\mathrm{O} / \mathrm{P}$ Placer \\
\hline Hecla Greens Creek Mining Company & Greens Creek Mine & $\begin{array}{l}\text { Juneau and } \\
\text { Admirality }\end{array}$ & $\mathrm{U} / \mathrm{G} H \mathrm{HR}$ \\
\hline Mark Sebens & Porcupine Creek & $\begin{array}{l}\text { Juneau and } \\
\text { Admirality }\end{array}$ & $\mathrm{O} / \mathrm{P}$ Placer \\
\hline $\begin{array}{l}\text { Snow Lion II Ltd. Partnership/Jerry } \\
\text { Fabrizio }\end{array}$ & Porcupine Creek & Porcupine & O/P Placer \\
\hline Coeur Alaska, Inc. & Kensington Gold Mine & Berners Bay & U/G HR \\
\hline
\end{tabular}

${ }^{\mathrm{a}} \mathrm{O} / \mathrm{P}=$ Open pit; $\mathrm{HR}=$ Hardrock; $\mathrm{U} / \mathrm{G}=$ Underground; $\mathrm{S} / \mathrm{D}=$ Suction Dredge; Large - Greater than or equal to an 8" nozzle. 


\section{APPENDIX E \\ Websites for commercial recreational mining ventures and mining-related attractions in Alaska}

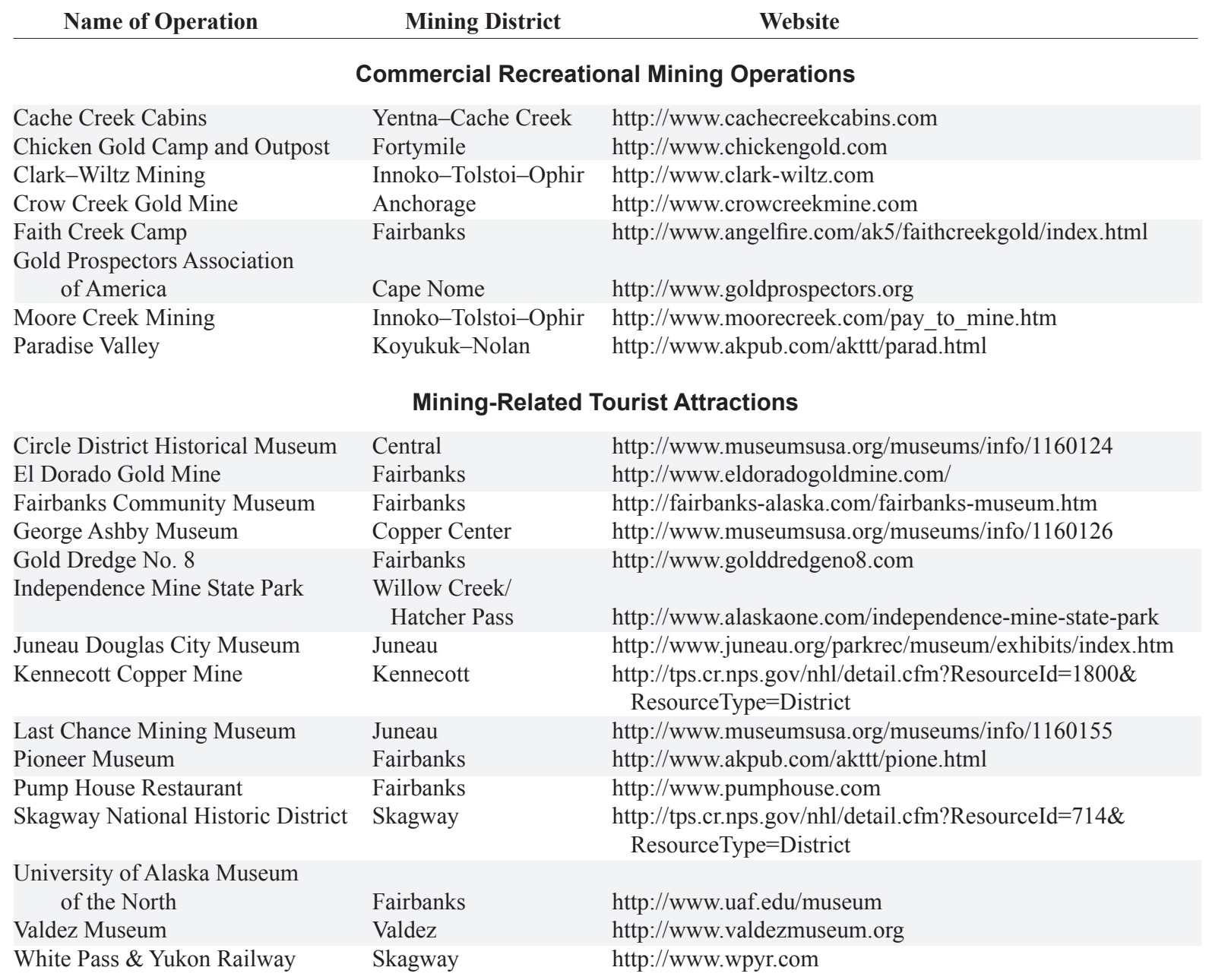

The lists of companies and attractions shown above are not intended to be comprehensive. 


\section{APPENDIX F \\ State and federal agencies and private interest groups involved in mineral development activities, 2009}

(The Alaska Miners Association Directory lists technical and professional consultants and companies available for work in Alaska. The report is published annually and is free to AMA members. The cost for non members is \$20 plus shipping and handling.)

\section{STATE OF ALASKA}

\section{OFFICE OF THE GOVERNOR}

Office of International Trade

550 West 7th Ave., Ste. 1700

Anchorage, AK 99501

(907) 269-7450

(907) 269-7461 (fax)

email: patricia.eckert@alaska.gov

Function: Primary state office for promotion of exports.

Maintains overseas offices to increase Alaska's visibility in key markets.

\section{DEPARTMENT OF COMMERCE, COMMUNITY \&} ECONOMIC DEVELOPMENT

State Office Building, 9th Fl.

P.O. Box 110801

Juneau, AK 99811-0801

(907) 465-2500

(907) 465-5442 (fax)

http://www.commerce.state.ak.us

Function: Promotes economic development in Alaska.

Division of Economic Development

550 W. 7th Ave., Ste. 1770

Anchorage, AK 99501

(907) 269-8110

(907) 269-8125 (fax)

Division of Economic Development

211 Cushman St.

Fairbanks, AK 99701-4639

(907) 451-2748

(907) 451-2742(fax)

email: lisa.harbo@alaska.gov

http://www.commerce.state.ak.us/oed/minerals/mining.htm

Function: Primary state government advocacy agency for economic growth. Researches and publishes economic data on Alaska's mining industry. Attracts capital investment by advertising Alaska's resource potential. Provides research staff aid for the Alaska Minerals Commission. In cooperation with the Office of International Trade, OED also encourages the development of new markets for Alaska resources, increases the visibility of Alaska and its products in the international marketplace, and makes referrals and provides technical assistance to those interested in developing export markets for Alaska-produced or value-added goods and services.

Alaska Industrial Development \& Export Authority (AIDEA) 813 W. Northern Lights Blvd.

Anchorage, AK 99503

(907) 269-3000

(907) 269-3044 (fax)

http://www.aidea.org

Function: AIDEA provides capital to finance economic growth throughout Alaska-from multi-million-dollar mining projects to small, family-owned businesses; from urban centers to small towns and rural villages. Regardless of project size, location, or business type, all AIDEA-financed projects must enhance the state's economy and provide or maintain jobs for Alaskans. AIDEA's financing assistance programs-the Credit Program and the Development Finance Program - have played an important role in Alaska's mineral development. The Credit Program includes the Loan Participation, Business and Export Assistance loan guarantee, and the Tax-Exempt Revenue Bond programs. AIDEA's Development Finance Program allows AIDEA to develop, own, and operate facilities within Alaska such as roads, ports, and utilities which are essential to the economic wellbeing of an area; are financially feasible; and are supported by the community in which they are located.

\section{P.O. Box 111800 Juneau, AK 99811-1800 (907) 465-5070 (fax) (907) 465-5065 Commissioner's Office http://www.dec.state.ak.us}

DEPARTMENT OF ENVIRONMENTAL CONSERVATION

Function: Issues permits for activities (including mining) that affect air or water quality or involve land disposal of wastes. Sets air-and water-quality standards. Inspects, monitors, and enforces environmental quality statutes, regulations, and permits. Reviews all federal permits.

Department of Environmental Conservation

Anchorage Office

555 Cordova St.

Anchorage, AK 99501-2617

(907) 269-7500

(907) 269-7600 (fax)

1-800-510-2332 (inside Alaska only)

http://www.dec.state.ak.us

Department of Environmental Conservation

Fairbanks Office

610 University Ave.

Fairbanks, AK 99709-3643

(907) 451-2100

(907) $451-5120$ (fax)

(907) 451-2184 TTY

http://www.dec.state.ak.us

\section{DEPARTMENT OF FISH AND GAME}

P.O. Box 115526

Juneau, AK 99811-5526

(907) 465-4100

(907) 465-2332

http://www.state.ak.us/adfg

Division of Habitat

Headquarters

P.O. Box 115526

Juneau, AK 99811-5526

(907) 465-2747

(907) 465-2066 (fax)

http://www.habitat.adfg.alaska.gov 
Function: The Division of Habitat fulfills specific statutory responsibilities for (1) protecting freshwater and anadromous fish habitat under the Anadromous Fish Act (AS 16.05.811) and (2) providing free passage of anadromous and resident fish in fresh waterbodies (AS 16.05.841). It requires prior written authorizations for any work affecting the free movement of fish, for any use or activity that may affect designated anadromous fish waters, and for any disturbance-producing or habitat-altering activity. The Division also authorizes activities in legislatively designated Special Areas (AS 16,.20.010- .630; 5 AAC95).

Operations Manager \& Fairbanks Area Office

1300 College Rd.

Fairbanks, AK 99701-1551

(907) 459-7289

(907) 459-7303 (fax)

Anchorage Area Office

333 Raspberry Rd.

Anchorage, AK 99518-1565

(907) $267-2342$

(907) 267-2499 (fax)

Juneau Office

P.O. Box 110024

Juneau, AK 99811-0024

(907) 465-4105

(907) 465-4759 (fax)

Kenai Area Office

514 Funny River Rd.

Soldotna, AK 99669-8255

(907) 714-2475

(907) 260-5992 (fax)

Mat-Su Area Office

1800 Glenn Highway, Ste. 12

Palmer, AK 99645-6736

(907) 761-3855

(907) 745-7369 (fax)

Prince of Wales Area Office

P.O. Box 668

Craig, AK 99921-0668

(907) 826-2560

(907) 826-2562 (fax)

DEPARTMENT OF NATURAL RESOURCES

Office of the Commissioner

550 W. 7th Ave., Ste. 1400

Anchorage, AK 99501

(907) 269-8431

http://www.dnr.alaska.gov

Alaska Coastal Management Program

302 Gold St., Ste. 202

Juneau, AK 99801

(907) 465-3562

(907) 465-3075 (fax)

Function: Conducts coordinated State reviews of mining projects within the coastal zone, while coordinating with Federal mining permitting agencies. Assists applicants in shaping mining projects to be consistent with the ACMP. Coordinates State response to Federal development activities and permitting actions (including proposed regulations) that affect Alaska's mining industry.
Southcentral Regional Office

550 W. 7th Ave., Ste. 1660

Anchorage, AK 99501-3568

(907) 269-7470

(907) 269-3981 (fax)

\section{Alaska Mental Health Trust Land Office}

718 L St., Ste. 202

Anchorage, AK 99501

(907) 269-8658

(907) 269-8905 (fax)

http://www.mhtrustland.org

Function: The Trust Land Office (TLO) manages the approximately 1 million acres of land that are included in the Alaska Mental Health Land Trust, which was created by Congress in 1956. Lands in the Trust are located throughout the state and are used to generate revenues to meet the expenses of mental health programs in Alaska. Management activities include all aspects of land use and resource development, including mineral and oil and gas leasing, exploration, and development; material sales (including gravel, sand, and rock); timber sales; surface leasing; land sales; and issuance of easements across Trust land.

Division of Forestry

550 W. 7th Ave., Ste. 1450

Anchorage, AK 99501-3566

(907) 269-8463

http://forestry.alaska.gov

Function: Establishes guidelines to manage mining in state forests.

Northern Region Office

3700 Airport Way

Fairbanks, AK 99709-4699

(907) 451-2670

Coastal Region Office

101 Airport Rd.

Palmer, AK 99645

(907) 761-6200

Division of Geological \& Geophysical Surveys

3354 College Rd.

Fairbanks, AK 99709-3707

(907) 451-5010

(907) 451-5050 (fax)

email: dggs@alaska.gov

http://www.dggs.alaska.gov

Function: Conducts geological and geophysical surveys to determine the potential of Alaska land for production of metal, mineral, fuel, and energy resources; locations and supplies of construction materials; potential geologic hazards to buildings, roads, bridges, and other installations and structures; and other surveys and investigations as will advance knowledge of the geology of Alaska (from AS 41.08.020). Publishes a variety of maps and reports and maintains a web site that contain the results of these investigations. Advises the public and government agencies on geologic issues. Maintains a library of geologic bulletins, reports, and periodicals. Maintains a Geologic Materials Center storage facility at Eagle River.

Geologic Materials Center

P.O. Box 772805

Eagle River, AK 99577-2805

(907) 696-0079

(907) 696-0078 (fax)

kenneth.papp@alaska.gov 
Division of Mining, Land \& Water

550 W. 7th Ave., Ste. 1070

Anchorage, AK 99501

\section{A. Mining}

Function: Principal agency for management of mining on state land in Alaska and reclamation of mined lands throughout Alaska. Maintains offices in Anchorage and Fairbanks. Issues property rights to leasable minerals; manages locatable mineral filings. Also issues millsite leases and permits for hard rock and placer mining activity. Maintains records of mineral locations, permits and leases. Provides technical, legal, and land-status information. Administers the Alaska Surface Mining Control and Reclamation Act (ASMCRA), which includes permitting and inspection of coal mining activity and reclamation of abandoned mines.

\section{B. Land}

Function: Manages surface estate and resources, including materials (gravel, sand, and rock) on state-owned lands. Handles statewide and regional land-use planning. Issues leases, material-sale contracts, land-use permits, and easements for temporary use of State land and access roads. Administers land sales program.

\section{Water Management}

Function: Manages water resources of the State; issues waterrights permits and certificates; responsible for safety of all dams in Alaska.

Regional Land \& Water Information:

Northern Regional Office

3700 Airport Way

Fairbanks, AK 99709-4699

(907) 451-2740

(907) 451-2751 (fax)

Southcentral Regional Office

550 W. 7th Ave., Ste. 900C

Anchorage, AK 99501

(907) 269-8503

(907) 269-8913 (fax)

Southeast Regional Office

400 Willoughby Ave., Ste. 400

Juneau, AK 99801-1724

(907) 465-3400

(907) 586-2954 (fax)

email: sero@dnr.state.ak.us

Division of Parks and Outdoor Recreation

550 W. 7th Ave., Ste. 1310

Anchorage, AK 99501-3565

(907) 269-8700

Function: Manages approximately 3,000,000 acres of state park lands primarily for recreational uses, preservation of scenic values, and watershed. Responsible for overseeing mining access, recreational mining activity, and valid mining-claim holdings within state park lands. The Office of History and Archaeology reviews mining permit applications on all lands within the state for impacts to historic resources.

Northern Regional Office 3700 Airport Way

Fairbanks, AK 99709-4699

(907) 451-2695
Southeast Area Office

400 Willoughby Ave., 5th Fl.

P.O. Box 111071

Juneau, AK 99811-1071

(907) 465-4563

(907 586-3113 (fax)

Office of History and Archaeology

550 W. 7th Ave., Ste. 1310

Anchorage, AK 99501-3565

(907) 269-8721

(907) 269-8908 (fax)

email: oha@alaska.net

http://dnr.alaska.gov/parks/oha/index.htm

\section{DEPARTMENT OF PUBLIC SAFETY}

Public Safety Headquarters

Office of the Commissioner

5700 East Tudor Rd.

Anchorage, AK 99507-1225

(907) 269-5086

(907) 269-4543 (fax)

http://www.dps.state.ak.us

\section{Alaska Wildlife Troopers \\ 5700 East Tudor Rd. \\ Anchorage, AK 99507-1225 \\ (907) 269-5509}

Function: Enforces state laws, in particular AS Title 16. Protects Alaska's fish and wildife resources through enforcement of laws and regulations governing use of natural resources within Alaska. These laws are in Alaska Statutes 8, 16, 46, and Alaska Administrative Codes 5, 12, and 20.

\section{DEPARTMENT OF REVENUE}

State Office Bldg.

11th Fl., Entrance A

P.O. Box 110400 (mailing)

Juneau, AK 99811-0400

(907) 465-2300

http://www.revenue.state.ak.us

Tax Division

550 W 7th Ave., Ste. 500

Anchorage, AK 99501-3555

(907) 269-6620

(907) 269-6444 (fax)

email: dor.tax.mining@alaska.gov

http://www.tax.alaska.gov/

Function: Issues licenses for sand and gravel operations. Administers mining-license tax based on net income, including royalties. New mining operations - except sand and gravel mining - can apply for and receive certificates of tax exemption for the first $3^{1 / 2}$ years of operation. (Tax returns must be filed annually.)

\section{UNIVERSITY OF ALASKA}

College of Natural Science and Mathematics

Department of Geology \& Geophysics

P.O. Box 755780

Natural Sciences Building, Room 308

University of Alaska Fairbanks

Fairbanks, AK 99775-5780

(907) 474-7565

(907) 474-5163 (fax) 
email: geology@.uaf.edu

http://www.uaf.edu/geology

Function: Provides undergraduate and graduate education in geology and geophysics and conducts basic and applied research in geologic sciences. For undergraduate studies, the department offers a B.A. program in Earth Science and a B.S. program in Geology (with emphasis options in general geology, economic geology, and petroleum geology). For graduate studies, the department offers M.S. and Ph.D. programs in Geology and Geophysics, with concentrations in: General geology; economic geology; petroleum geology; Quaternary geology; remote sensing; volcanology; solid-earth geophysics; and snow, ice, and permafrost geophysics.

\section{College of Engineering and Mines}

P.O. Box 755960

Duckering Building, Room 357

University of Alaska Fairbanks

Fairbanks, AK 99775-5960

(907) 474-7730

(907) 474-6994 (fax)

email: fycem@uaf.edu

http://www.uaf.edu/cem

Function: Provides undergraduate and graduate education programs in geological engineering, mining engineering, mineral preparation engineering, civil engineering, mechanical engineering, and electrical engineering. Through research programs, conducts laboratory and field studies to promote mineral and energy development.

Mineral Industry Research Laboratory (MIRL)

College of Engineering and Mines

P.O. Box 757240

Duckering Building, Room 403

University of Alaska Fairbanks

Fairbanks, AK 99775-7240

(907) 474-6746

(907) 474-5400 (fax)

email: ffdew1@uaf.edu

Function: Conducts applied and basic research in exploration development, and utilization of Alaska's mineral and coal resources with emphasis on coal characterization, coal utilization, coal upgrading, coal preparation, mineral beneficiation, fine gold recovery, hydrometallurgy, and environmental concerns. Publishes reports on research results and provides general information and assistance to the mineral industry.

Department of Mining and Geological Engineering

College of Engineering and Mines

P.O. Box 755800

Duckering Building, Room 301

University of Alaska Fairbanks

Fairbanks, AK 99775-5800

(907) 474-7388

(907) 474-6635 (fax)

email: fyminge@uaf.edu

http://www.uaf.edu/cem

Function: Provides undergraduate and graduate education programs in geological engineering, mining engineering, and mineral preparation engineering. Through research programs, conducts laboratory and field studies to promote mineral and energy development.

Mining and Petroleum Training Service

162 College Rd.

University of Alaska
Soldotna, AK 99669

(907) $262-2788$

(907) 262-2812 (fax)

email:mapts@alaska.net

www.mapts.alaska.edu

Function: Provides direct training and assistance to mine operators, service and support companies, and governmental agencies in mine safety and health, mining extension, vocational mine training, and technical transfer. Specialized training services in hazardous materials, first aid and CPR, and industrial hygiene. Professional safety education and consulting are available on demand.

\section{FEDERAL AGENCIES}

\section{U.S. DEPARTMENT OF THE INTERIOR}

Office of the Secretary

1689 C St., Ste. 100

Anchorage, AK 99501-5151

(907) 271-5485

(907) 271-4102

Function: Coordinates the Department of the Interior's policy and stewardship with DOI bureaus for the management of more than 200 million acres of public land in Alaska.

\section{U.S. Bureau of Land Management}

Alaska State Office

Division of Lands, Minerals, and Resources

222 West 7th Ave., Ste. 13

Anchorage, AK 99513-7599

Public Information Center (907) 271-5960

Northern Field Office (907) 474-2252

Public Information Center

http://www.ak.blm.gov/

Energy Branch (907) 271-5049

Solid Minerals Branch (907) 271-5049

\section{Division Functions:}

$B L M$ is the surface manager of federal public lands (except national parks, wildlife refuges, national monuments, national forests, and military withdrawals). The Division is responsible for developing and coordinating statewide and regional program management policies and strategies related to federal onshore energy and non-energy leasable minerals, mineral assessments, and locatable minerals. It provides technical assistance and coordinates activities relating to ANILCA 1010 mineral assessments. The Division provides the basis for economic analysis relating to energy and mineral development in the state. It also provides leadership and technical assistance on abandoned mine lands inventories and impacts on public lands.

\section{Energy Branch Functions:}

The Branch is responsible for the federal onshore mineral leasing programs and functions; including oil and gas, geothermal resources, coal, and other energy and non-energy minerals. The Branch prepares and conducts oil and gas lease sales and is responsible for preparing pre- and post-lease sale fair market value evaluations for National Petroleum Reserve-Alaska leasing, and issuing leases; adjudicates oil and gas leases, transfers, and bonds; approves oil and gas industry operations for federal onshore oil and gas leases; protects federal lands from drainage of oil and gas resources, and inspects industry operations for compliance; and coordinates with other federal surface management agencies for the leasing and monitoring of minerals operations under their jurisdictions. 


\section{Solid Minerals Branch Functions:}

The Branch maintains mining claim and mineral patent case files and electronic public minerals records related to those files. It adjudicates federal mining claim recordation filings, annual assessment affidavits, and timely payment of annual claim holding fees. It also adjudicates mineral survey and patent applications, and serves contest complaints for all federal lands in Alaska.

Anchorage Field Office

6881 Abbott Loop Rd.

Anchorage, AK 99507-2599

(907) 267-1246

(907) 267-1267 (fax)

Glennallen Field Office

P.O. Box 147

Glennallen, AK 99588

(907) 822-3217

(907) 822-3120 (fax)

http://www.glennallen.ak.blm.gov

Kotzebue Field Station

P.O. Box 1049

Kotzebue, AK 99752-1049

(907) 442-3430

(907) 442-2720 (fax)

Nome Field Station

P.O. Box 925

Nome, AK 99762-0925

(907) 443-2177

(907) 443-3611 (fax)

Northern Field Office

1150 University Ave.

Fairbanks, AK 99709-3899

(907) 474-2200

(907) 474-2251 Public Room

(907) 474-2282 (fax)

1-800-437-7021

Tok Field Station

P.O. Box 309

Tok, AK 99780

(907) 883-5121

(907) 883-5123 (fax)

\section{U.S. Fish and Wildlife Service}

Region 7 Office

Mail Stop 361

1011 East Tudor Rd.

Anchorage, AK 99503

(907) 786-3542

http://alaska.fws.gov/

Function: Administers the federal public lands in national wildlife refuges, issues special-use permits for activities on refuges, reviews permits and applications for various mining activities on all private and public lands and waters, and provides information to regulatory agencies on fish and wildlife and their habitat. Makes recommendations to regulatory agencies to mitigate adverse environmental impacts.

U.S. Fish and Wildlife Service Fairbanks Fish and Wildlife Field Office 101 12th Ave., Room 110

Fairbanks, AK 99701
(907) 456-0203

(907) 456-0208 (fax)

U.S. Fish and Wildlife Service

Juneau Fish and Wildlife Field Office

3000 Vintage Blvd., Ste. 201

Juneau, AK 99801-7100

(907) $780-1160$

(907) 586- 7154 (fax)

U.S. Fish and Wildlife Service

Anchorage Fish and Wildlife Field Office

605 West 4th Ave., Rm. G-61

Anchorage, AK 99501

(907) 271-2888

(907) 271-2786 (fax)

U.S. Geological Survey

Alaska Science Center

Geology Office

4200 University Dr.

Anchorage, AK 99508-4667

(907) 561-1181

Function: The mission of the USGS Alaska Science Center (ASC) is to provide scientific leadership and accurate, objective, and timely data, information, and research findings about the earth and its flora and fauna to Federal and State resource managers and policy makers, local government, and the public to support sound decision making regarding natural resources, natural hazards, and ecosystems in Alaska and circumpolar regions.

Geologic Discipline programs in the ASC are based on insightful monitoring, assessments, and research activities that address natural hazards, earth resources, and geologic processes. The Geologic Discipline provides comprehensive, high quality, and timely scientific information to decision makers at Federal, State, and local government levels, as well as the private sector. The Minerals Program investigates and reports on the occurrence, quality, quantity, and environmental characteristics of mineral resources in Alaska, the processes that create and modify them, models for assessing mineral endowment, and the potential impacts of mineral development.

U.S. Geological Survey

Alaska Science Center

National Geospatial Program Office

4230 University Dr., Ste. 101

Anchorage, AK 99508-4664

(907) 786-7011

Function: Publishes and distributes all available topographic maps of Alaska, digital products, and aerial photography.

\section{National Park Service}

Alaska Regional Office

Natural Resources Science Team

240 W. 5th Ave.

Anchorage, AK 99501

(907) 644-3571

(907) 644-3809 (fax)

Function: Administers lands within the national park system in Alaska. Manages oil and gas operations and pre-existing valid mining claims in parklands through plans of operation under Mining in Parks Act, National Park Service regulations, and other applicable federal and state laws and regulations. 


\author{
U.S. DEPARTMENT OF LABOR \\ Mine Safety and Health Administration \\ Mailing Address: \\ Anchorage Federal Building \\ US Courthouse - Rm. A-35 \\ 222 West 7 th Ave., Box 30 \\ Anchorage, AK 99513 \\ (907) 271-1250 \\ (907) 271-1252 (fax) \\ email: bowen.ayers@dol.gov \\ Physical Address: \\ 222 W. 8th Ave A-35 \\ Anchorage, AK 99513 \\ (907) 271-1250 \\ (907) 271-1252 (fax) \\ email: bowen.ayers@dol.gov
}

Function: Administers health and safety standards to protect the health and safety of metal, nonmetal, and coal miners. Cooperates with the State to develop health and safety programs and develops training programs to help prevent mine accidents and occupationally caused diseases. Under agreement with the Coal Mine Safety and Health Office, the MSHA metal/nonmetal section has assumed responsibility for enforcement and training activities at coal mines in Alaska.

Mine Safety and Health Administration

Coal Mine Safety and Health, District 9

P.O. Box 25367

Denver, CO 80225

(303) 231-5458

(303) 231-5553 (fax)

http://www.msha.gov

Function: Administers health and safety standards according to the Code of Federal Regulations to protect the health and safety of coal miners; requires that each operator of a coal mine comply with these standards. Cooperates with the State to develop health and safety programs and develops training programs to help prevent coal or other mine accidents and occupationally caused diseases in the industry.

\section{U.S. DEPARTMENT OF AGRICULTURE}

Forest Service

Regional Office, R.L.M.

Attn: John Kato

Assistant Director for Minerals and Geology Programs

P.O. Box 21628

Juneau, AK 99802-1628

(907) 586-7869

(907) 586-7866 (fax)

email: jkato@fs.fed.us

http://www.fs.fed.us/

Function: With the Bureau of Land Management, provides joint administration of general mining laws on national forest system lands. Cooperates with Department of Interior agencies in the review and issuance of mineral leases. Issues permits for disposal of sand, gravel, and stone.

\section{U.S. ENVIRONMENTAL PROTECTION AGENCY}

Region 10 Regional Office

1200 6th Ave., MS OW-130

Seattle, WA 98101

(206) $553-1200$

(206) 553-1746 (NPDES permits)

http://www.epa.gov/r10earth/

Function: Issues National Pollutant Discharge Elimination System (NPDES) permits under the Clean Water Act to regulate effluent discharges. Implements a compliance enforcement program. Maintains regulatory and review authority over wetland and NEPA/EIS-related issues.

Alaska Operations Office 222 West 7th Ave., Rm. 537

222 W. 7th Ave., Box 19 (mailing)

Anchorage, AK 99513-7588

(907) 271-5083

Alaska Operations Office

709 W 9th St., Rm. 223A

Box 20370 (mailing)

Juneau, AK 99802-0370

(907) 586-7619

\section{U.S. DEPARTMENT OF THE ARMY}

Corps of Engineers

Regulatory Division

2204 3rd St.

P.O. Box 6898

Elmendorf Air Force Base, AK 99506-0898

(907) $753-2712$

(907) 753-5567 (fax)

(800) 478-2712 (in Alaska only)

http://www.poa.usace.army.mil/reg

Function: Regulates structures or work in navigable waters of the U.S. and discharge of dredged or fill material into U.S. waters, including wetlands. Under Section 404 of the Clean Water Act, the Corps of Engineers issues dredge and fill permits for certain mining activities in waters of the United States. Examples of regulated mining activities include construction of berms, dikes, diversions, ponds, overburden stripping, stockpiling, and reclamation activities.

\section{COOPERATIVE STATE-FEDERAL AGENCIES}

Alaska Public Lands Information Center

101 Dunkel St., Ste 110

Fairbanks, AK 99701

(907) 459-3730

(907) 459-3729 (fax)

www.alaskacenters.gov

Function: Clearinghouse for general information on outdoor recreation in Alaska. Information sources include U.S. Forest Service, U.S. Fish and Wildlife Service, U.S. Bureau of Land Management, U.S. Geological Survey, National Park Service, Alaska Departments of Natural Resources, Fish and Game, Community and Economic Development, and Transportation and Public Facilities.

\section{BOARDS AND COMMISSIONS}

\section{Alaska Minerals Commission}

Irene Anderson, Chair

c/o Bering Straits Native Corp.

P.O. Box 1008

Nome, AK 99762

(907) 443-5252

(907) 443-4317

(907) 443-2985 (fax)

email: irene@beringstraits.com

Function: The Minerals Commission was created by the Alaska State Legislature in 1986 to make recommendations to the Governor and the Legislature on ways to mitigate constraints on the development of minerals in Alaska. The Commission has published annual reports since 1987. 


\section{CHAMBERS OF COMMERCE}

Alaska State Chamber of Commerce

217 Second St., Ste. 201

Juneau, AK 99801

(907) 586-2323

(907) 463-5515 (fax)

email: info@alaskachamber.com

http://www.alaskachamber.com

Function: The State Chamber of Commerce researches and formulates positions on Alaskan resource development. Recommendations for consideration are submitted to the State Chamber of Commerce board of directors.

Anchorage Chamber of Commerce 1016 W. 6th Ave., Ste. 303

Anchorage, AK 99501

(907) 272-2401

email: info@anchoragechamber.org http://www.anchoragechamber.org

Function: To be effective as a business leader by supporting and focusing its broad-based membership in their efforts to advance a successful business climate.

Greater Fairbanks Chamber of Commerce

100 Cushman St., Ste. 102

Fairbanks, AK 99701

(907) 452-1105

(907) 456-6968 (fax)

email: info@fairbankschamber.org http://www.fairbankschamber.org

Juneau Chamber of Commerce

3100 Channel Dr., Ste. 300

Juneau, AK 99801

(907) 463-3488

(907) 463-3489 (fax)

email: juneauchamber@gci.net

http://www.juneauchamber.com

\section{PUBLIC INTEREST GROUPS} AND ASSOCIATIONS

Alaska Miners Association Inc.

Statewide Office

Steven C. Borell, P.E., Executive Director 3305 Arctic Blvd., Ste. 105

Anchorage, AK 99503

(907) 563-9229

(907) 563-9225 (fax)

email: ama@alaskaminers.org

http://www.alaskaminers.org

\section{AMA BRANCHES \\ Anchorage Juneau \\ Denali Kenai \\ Fairbanks Nome}

Please contact AMA for current contacts

Alaskans for Responsible Mining 810 N St.

Anchorage, AK 99501
(907) 277-0005

(907) 277-0990 (fax)

email: vanessa@reformakmines.org

American Institute of

Professional Geologists

12000 N. Washington St., Suite 285

Thornton, CO 80241-3134

(303) 412-6205

(303) 253-9220 (fax)

email: aipg@aipg.org

http://www.aipg.org

Earthjustice

325 Fourth St.

Juneau, AK 99801

(907) 586-2751

(907) 463-5891 (fax)

email: eajusak@earthjustice.org

http://www.earthjustice.org

National Wildlife Federation

750 W. Second Ave., Ste. 200

Anchorage, AK 99501

(907) 339-3900

(907) 339-3980 (fax)

Northern Alaska Environmental Center 830 College Rd.

Fairbanks, AK 99701-1535

(907) $452-5021$

(907) 452-3100 (fax)

email: info@northern.org

http://www.northern.org

Northwest Mining Association

10 North Post St., Ste. 305

Spokane, WA 99201

(509) 624-1158

(509) 623-1241 (fax)

email: nwma_info@nwma.org

http://www.nwma.org

Resource Development Council for Alaska, Inc.

121 W. Fireweed Ln., Ste. 250

Anchorage, AK 99503

(907) 276-0700

(907) 276-3887 (fax)

email: Resources@akrdc.org

http://www.akrdc.org

Society for Mining, Metallurgy, and

Exploration Inc.

8307 Shaffer Parkway

Littleton, CO 80127

(303) 973-9550

(303) 973-3845 (fax)

email: sme@smenet.org

http://www.smenet.org

Southeast Alaska Conservation Council

(SEACC)

419 6th St., Ste. 200

Juneau, AK 99801

(907) 586-6942

(907) 463-3312 (fax) email: info@seacc.org

http://www.seacc.org

Trustees for Alaska

1026 W. 4th Ave., \# 201

Anchorage, AK 99501-1980

(907) 276-4244

email: ecolaw@trustees.org

http://www.trustees.org

\section{ORGANIZED MINING DISTRICTS}

Circle Mining District

P.O. Box 30181

Central, AK 99730-0181

(907) 520-5419 (message)

Fairbanks Mining District

105 Dunbar

Fairbanks, AK 99701

(907) 456-7642

Fortymile Mining District

Sheldon Maier, President

General Delivery

Chicken, AK 99732

Haines Mining District

P.O. Box 149

Haines, AK 99827

(907) 766-2821

Iditarod Mining District

John A. Miscovich

1093 N. Greengrove St.

Orange, CA 92867

Yentna Mining District

Carol Young

P.O. Box 211

Talkeetna, AK 99676

(907) 733-2351

\section{MINERAL EDUCATION \\ PROGRAMS}

ALASKA RESOURCE EDUCATION

4141 B Street, Suite 402

Anchorage, AK 99503

(907) 276-5487

(907) 276-5488 (fax)

email: kits@akresource.org

http://www.akresource.org

Function: A 501c(3) educational non-profit whose mission is to provide Alaska's students with the knowledge to make informed decisions relating to mineral, energy, and forest resources.

\section{NATIVE REGIONAL} CORPORATIONS

AHTNA INC.

Kathryn Martin

VP Land and Resources

P.O. Box 649 
Glennallen, AK 99588-0649

(907) 822-3476

(907) 822-3495 (fax)

email:kmartin@ahtna-inc.com

http://www.ahtna-inc.com/

Anchorage Office

Linda Tyone

VP of Corporate Affairs

406 W. Fireweed, Ste. 201

Anchorage, AK 99503

(907) 868-8202

(907) 868-8284 (fax)

email:1tyone@ahtna-inc.com

http://www.ahtna-inc.com/

THE ALEUT CORP.

4000 Old Seward Hwy., Ste. 300

Anchorage, AK 99503-6087

(907) $561-4300$

(907) 563-4328 (fax)

email:MSmith@aleutcorp.com

http://www.aleutcorp.com

ARCTIC SLOPE REGIONAL CORP.

P.O. Box 129

Barrow, AK 99723-0129

(907) 852-8633

(907) 852-5733 (fax)

http://www.asrc.com/

Anchorage Office

3900 C St., Ste. 801

Anchorage, AK 99503-5963

(907) 339-6000

(907) 339-6028 (fax)

BERING STRAITS NATIVE CORP.

Larry Pederson

Land Manager

P.O. Box 1008

Nome, AK 99762-1008

(907) 443-4312
(907) 443-2985 (fax)

email: Lpederson@beringstraits.com

http://www.beringstraits.com/

Anchorage Office

Matt Ganley

4600 DeBarr Rd., Ste 200

Anchorage, AK 99508-3126

(907) 344-7212

(907) 563-2742 (fax)

email: matt@beringstraits.com

BRISTOL BAY NATIVE CORP.

111 West 16th Ave., Ste. 400

Anchorage, AK 99501-5109

(907) 278-3602

(907) 276-3924 (fax)

http://www.bbnc.net

CALISTA CORP.

301 Calista Court, Ste. A

Anchorage, AK 99518-3028

(907) 279-5516

(907) 272-5060 (fax)

http://www.calistacorp.com/

CHUGACH ALASKA CORP.

3800 Centerpoint Dr., Suite 601

Anchorage, AK 99503-4196

(907) 563-8866

email: dphillips@chugach-ak.com

http://www.chugach-ak.com/

COOK INLET REGION INC.

and its subsidary North Pacific

Mining Corporation

2525 C St., Ste. 500

Anchorage, AK 99503

(907) 274-8638

(907) 263-5190 (fax)

email: kcunningham@ciri.com

http://www.ciri.com/
DOYON LTD.

Doyon, Limited

1 Doyon Place, Suite 300

Fairbanks, AK 99701-2941

(907) 459-2030

(907) 459-2062 (fax)

email: lands@doyon.com

http://www.doyonlands.com

KONIAG INC

Charlie Powers, V.P. Corporate Affairs

194 Alimaq Dr.

Kodiak, AK 99615-6389

(907) 486-2530

(907) 486-3325 (fax)

cpowers@koniag.com

www.koniag.com

NANA REGIONAL CORP.

P.O. Box 49

Kotzebue, AK 99752

(907) 442-3301

(907) 442-2866 (fax)

http://www.nana.com

Anchorage Office

Nana Development Corp.

1001 E. Benson Blvd.

Anchorage, AK 99508

(907) 265-4100

(907) 265-4311 (fax)

SEALASKA CORP.

One Sealaska Plaza, Ste. 400

Juneau, AK 9980

(907) 586-1512

(907) 463-3897 (fax)

http://www.sealaska.com/ 


\section{APPENDIX G Alaska mining websites}

\section{Mining and Exploration Companies}

Alaska Earth Sciences Inc.

Alix Resources Corp.

Altair Ventures Inc.

Anchorage Sand and Gravel Co. Inc.

Andover Ventures Inc.

Anglo American plc

Anglo American Exploration (USA) Inc.

Ashburton Ventures Inc.

Avalon Development Corp.

Barrick Gold Corp.

BHP Billiton Ltd.

Black Range Minerals Ltd.

Bravo Venture Group Inc.

Brett Resources Inc.

Browns Hill Quarry

CBR Gold Corp. (Committee Bay Resources Ltd.)

Century Mining Corp.

Chuitna Coal Project

Clark-Wiltz Mining

Coeur d'Alene Mines Corp. (Coeur Alaska Inc.)

Constantine Metal Resources Ltd.

Contango Oil \& Gas Co.

Copper Ridge Explorations Inc.

Fire River Gold Corp.

Freegold Ventures Ltd.

Full Metal Minerals Ltd.

Geocom Resources Inc.

Geohedral LLC

Geoinformatics Exploration Inc.

Gold Crest Mines Inc.

Goldrich Mining Co. (Little Squaw Gold Mining Co.)

Grayd Resource Corp.

Great Basin Gold Ltd.

Great Northwest Inc.

Greens Creek Mining Co.

Hecla Mining Co.

Hinterland Metals Inc.

International Tower Hill Mines Ltd. (Talon Gold (US) LLC)

Kinross Gold Corp. (Fairbanks Gold Mining Inc.)

Kiska Metals Corp.

Lafarge North America Inc.

Liberty Star Gold Corp.

Linux Gold Corp.

Mantra Mining Inc.

Max Resource Corp.

Millrock Resources Inc.

Moore Creek Mining LLC

New Gold Inc.

Next Gen Metals Inc.

Northern Associates Inc.

Northern Dynasty Minerals Ltd.

NovaGold Resources Inc. http://www.aes.alaska.com

http://www.alixresources.com/

http://www.altairventuresinc.com/

http://www.anchsand.com

http://www.andoverventures.com/

http://www.angloamerican.co.uk/

http://www.angloamerican.ca/

http://www.ashburtonventures.com/

http://www.avalonalaska.com

http://www.barrick.com/

http://www.bhpbilliton.com/

http://www.blackrangeminerals.com/

http://www.bravoventuregroup.com/

http://www.brettresources.com/s/Home.asp

http://www.bricecompanies.com/quarry.html

http://www.cbrgoldcorp.com/

http://www.centurymining.com

http://www.chuitnaseis.com/default.htm

http://www.clark-wiltz.com/

http://www.coeur.com

http://www.constantinemetals.com/

http://www.contango.com/

http://www.copper-ridge.com

http://www.firerivergold.com/

http://www.freegoldventures.com

http://www.fullmetalminerals.com

http://www.geocom-resources.com

http://beardco.com/investor-relations/press-

releases

http://www.kiskametals.com/s/Home.asp

http://www.goldcrestminesinc.com/

http://www.goldrichmining.com/

http://www.grayd.com

http://www.greatbasingold.com/

http://www.grtnw.com/

http://www.greenscreek.com/

http://www.hecla-mining.com

http://www.hinterlandmetals.com/

http://www.ithmines.com/s/home.asp

http://www.kinross.com

http://kiskametals.com/

http://www.lafargenorthamerica.com/wps/portal/

http://www.libertystaruranium.com

http://www.linuxgoldcorp.com

http://www.mantramining.com/

http://www.maxresource.com/s/Home.asp

http://www.millrockresources.com/

http://www.moorecreek.com/index.html

http://www.newgold.com/

http://www.nextgenmetalsinc.com/

http://www.alaskaexploration.com

http://www.northerndynastyminerals.com

http://www.novagold.net 
Pacific North West Capital Corp.

Paradise Valley Inc.

Pebble Limited Partnership

Pure Nickel Inc.

Quaterra Resources Inc.

Rimfire Minerals Corp.

Rio Tinto Ltd.

Rubicon Minerals Corp.

Select Resources Corp. (Tri-Valley Corp.)

Senator Minerals Inc.

Silverado Gold Mines Ltd.

Sisyphus Consulting

Sumitomo Metal Mining Co. Ltd

Teck Resources Ltd.

Teryl Resources Corp.

TintinaGold Resources Inc.

TNR Gold Corp.

Triton Gold Ltd.

Ucore Uranium Inc.

Usibelli Coal Mine Inc.

Valdez Gold Inc.

YOW Capital Corp.

Zazu Metals Corp. http://www.pfncapital.com

http://www.akpub.com/akttt/parad.html

http://www.pebblepartnership.com/

http://www.purenickel.com/s/Home.asp

http://www.quaterraresources.com/

http://www.rimfire.bc.ca

http://www.riotinto.com/

http://www.rubiconminerals.com

http://www.tri-valleycorp.com

http://www.senatorinc.com/

http://www.silverado.com

http://www.sisyphus-consulting.com

http://www.sumitomocorp.co.jp/english/

http://www.teck.com

http://www.terylresources.com

http://www.tintinagold.com/

http://www.tnrgoldcorp.com

http://www/tritongold.au/

http://www.ucoreuranium.com/

http://www.usibelli.com

http://www.valdezgold.ca

http://www.yowcapital.com/index.cfm

http://www.zazumetals.com/s/Home.asp

\section{Alaska Native Corporations}

Ahtna Inc.

Aleut Corp.

Arctic Slope Regional Corp.

Bering Straits Native Corp.

Bristol Bay Native Corp.

Calista Corp.

Chugach Alaska Corp.

Cook Inlet Region Inc.

Doyon Ltd.

Koniag Inc.

NANA Regional Corp.

Sealaska Corp.

General

Alaska Miners Association

Alaska Division of Geological \& Geophysical Surveys

Alaska Office of Economic Development http://www.ahtna-inc.com http://www.aleutcorp.com http://www.asrc.com http://www. beringstraits.com http://www.bbnc.net http://www.calistacorp.com http://www.chugach-ak.com http://www.ciri.com http://www.doyon.com http://www.koniag.com http://www.nana.com http://www.sealaska.com

http://www.alaskaminers.org

http://dggs.alaska.gov

http://www.commerce.state.ak.us/oed/home.htm

\section{Alaska's Minerals Data and Information Rescue in Alaska (MDIRA) Project Websites}

MDIRA Portal Home Page

Alaska Geology Map Indexer

Alaska Mining Claims Information System

Alaska Resource Data Files

DGGS Publications On-Line

DNR Sites Related to Mining Applications and Forms

Alaska Mining License Tax Forms

DNR Production Royalty Form

Guide to Alaska Geologic and Mineral Information http://akgeology.info

http://maps.akgeology.info

http://akmining.info

http://ardf.wr.usgs.gov

http://dggs.alaska.gov/index.php?menu_link=publ ications\&link=publication_sales

http://dnr.alaska.gov/mlw/forms/

http://www.tax.alaska.gov/programs/programs/ forms/index.aspx?60610

http://dnr.alaska.gov/mlw/forms/mining/royalty_ fm.pdf

http://dggs.alaska.gov/webpubs/dggs/ic/text/ ic044ed2004.PDF 
Land Records Web Application

NURE Data

RASS, PLUTO Geochemistry Data

State Map Library

State Recorder's Office Search

State Uniform Commercial Code (UCC) Documents Search http://plats.landrecords.info/index.html http://pubs.usgs.gov/of/1997/ofr-97-0492/quad_ ak/q_iditar.htm

http://pubs.usgs.gov/of/1999/of99-433/

http://dnr.alaska.gov/ssd//ris/gis/gis_maplib/maplib_start.cfm

http://dnr.alaska.gov/ssd/recoff/search.cfm http://dnr.alaska.gov/ssd/ucc/search.cfm 
APPENDIX H

\section{U.S. Customary Units/Metric Units Conversion Chart}

\begin{tabular}{|c|c|c|}
\hline To convert from: & To: & Multiply by: \\
\hline \multicolumn{3}{|c|}{ Weight/Mass/Ore Content } \\
\hline ounces (avoirdupois) & grams & 28.350 \\
\hline ounces (troy) & grams & 31.1035 \\
\hline pounds & kilograms & 0.4536 \\
\hline short tons & metric tons & 0.9072 \\
\hline grams & ounces (avoirdupois) & 0.03527 \\
\hline & ounces (troy) & 0.03215 \\
\hline kilograms & pounds & 2.2046 \\
\hline metric tons & short tons & 1.1023 \\
\hline parts per million (ppm) & parts per billion (ppb) & 1,000 \\
\hline parts per million (ppm) & ounces per ton & 0.0292 \\
\hline parts per million (ppm) & grams/metric tons (tonnes) & 1.00 \\
\hline \multicolumn{3}{|c|}{ Length } \\
\hline miles & kilometers & 1.6093 \\
\hline yards & meters & 0.9144 \\
\hline \multirow[t]{3}{*}{ feet } & meters & 0.3048 \\
\hline & centimeters & 30.48 \\
\hline & millimeters & 304.80 \\
\hline \multirow[t]{2}{*}{ inches } & centimeters & 2.54 \\
\hline & millimeters & 25.4 \\
\hline kilometers & miles & 0.6214 \\
\hline \multirow[t]{2}{*}{ meters } & yards & 1.0936 \\
\hline & feet & 3.2808 \\
\hline \multirow[t]{2}{*}{ millimeters } & feet & 0.00328 \\
\hline & inches & 0.03937 \\
\hline centimeters & inches & 0.3937 \\
\hline \multicolumn{3}{|c|}{ Area } \\
\hline square miles & square kilometers & 2.590 \\
\hline \multirow[t]{2}{*}{ acres } & square meters & $4,046.873$ \\
\hline & hectares & 0.4047 \\
\hline square yards & square meters & 0.8361 \\
\hline square feet & square meters & 0.0929 \\
\hline \multirow[t]{2}{*}{ square inches } & square centimeters & 6.4516 \\
\hline & square millimeters & 645.16 \\
\hline square kilometers & square miles & 0.3861 \\
\hline square meters & acres & \\
\hline \multicolumn{3}{|l|}{0.000247} \\
\hline & square feet & 10.764 \\
\hline & square yards & 1.196 \\
\hline \multirow[t]{2}{*}{ hectares } & acres & 2.471 \\
\hline & square meters & $10,000.00$ \\
\hline square centimeters & square inches & 0.155 \\
\hline square millimeters & square inches & 0.00155 \\
\hline \multicolumn{3}{|c|}{ Volume } \\
\hline cubic yards & cubic meters & 0.7646 \\
\hline cubic feet & cubic meters & 0.02832 \\
\hline cubic inches & cubic centimeter & 16.3871 \\
\hline \multirow[t]{2}{*}{ cubic meters } & cubic yards & 1.3079 \\
\hline & cubic feet & 35.3145 \\
\hline cubic centimeters & cubic inches & 0.06102 \\
\hline gallons (U.S.) & liters & 3.7854 \\
\hline liters & gallons (U.S.) & 0.2642 \\
\hline milliliters & ounces (fluid) & 0.03381 \\
\hline ounces (fluid) & milliliters & 29.5735 \\
\hline
\end{tabular}

Temperature conversions:

From degrees Fahrenheit to degrees Celsius, subtract 32 and multiply by 5/9.

From degrees Celsius to degrees Fahrenheit, multiply by $9 / 5$ and add 32 . 


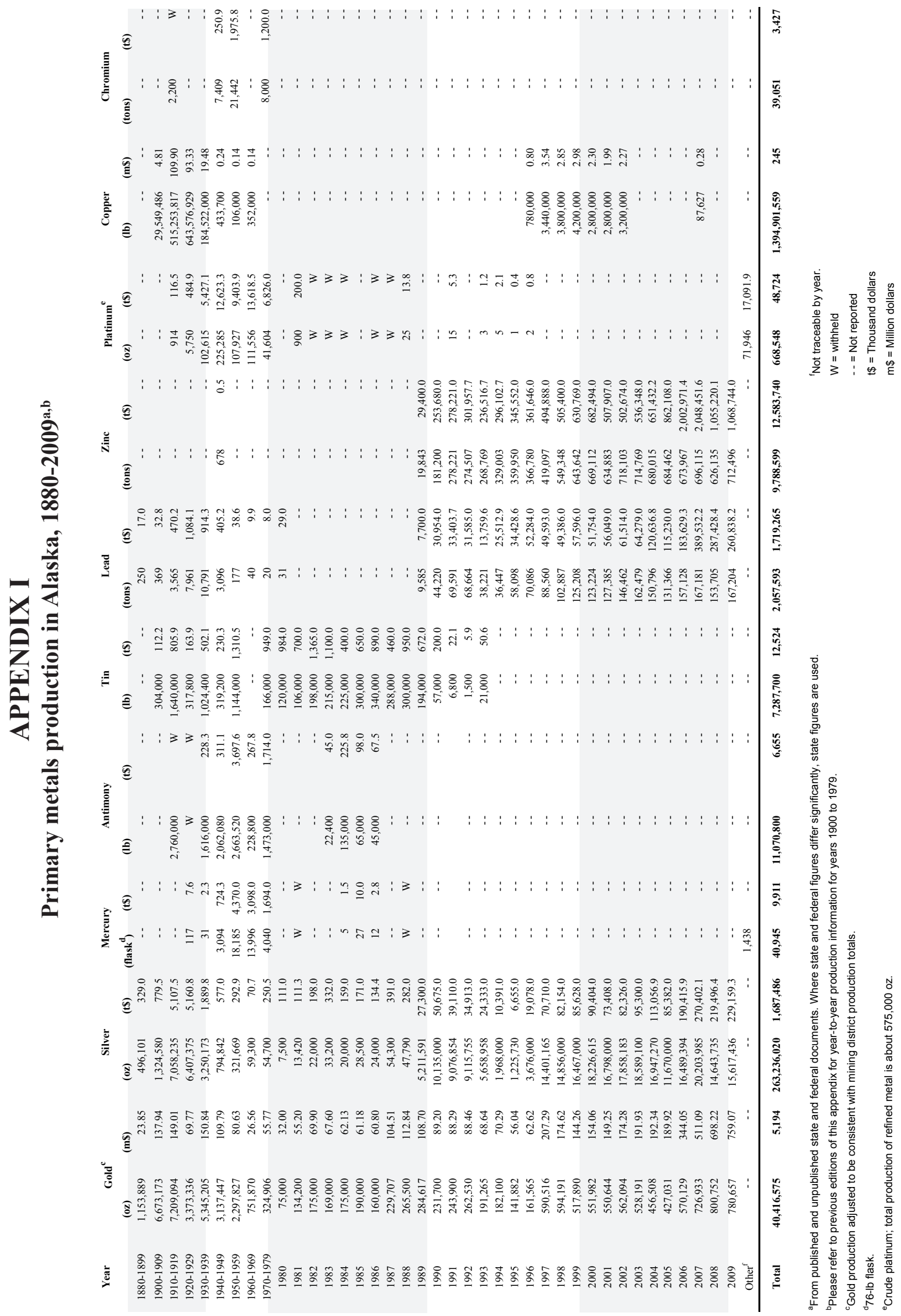




\section{APPENDIX J}

Production of industrial minerals, coal, and other commodities in Alaska, 1880-2009a,b

\begin{tabular}{|c|c|c|c|c|c|c|c|c|c|}
\hline \multirow[b]{2}{*}{ Year } & \multicolumn{2}{|c|}{ Coal } & \multicolumn{2}{|c|}{ Sand and gravel } & \multicolumn{2}{|c|}{ Rock $^{\mathrm{c}}$} & \multicolumn{2}{|c|}{ Barite } & \multirow{2}{*}{$\begin{array}{c}\text { Other }^{\mathrm{d}} \\
\$\end{array}$} \\
\hline & s. tons & $\mathbf{m} \$$ & s. tons & $\mathbf{m} \$$ & s. tons & $\mathbf{m} \$$ & s. tons & t\$ & \\
\hline 1880-1899 & 19,429 & 0.14 & -- & - - & 7,510 & 0.04 & -- & -- & \\
\hline 1900-1909 & 33,214 & 0.20 & - - & - - & 15,318 & 0.18 & - - & - - & 246,403 \\
\hline 1910-1919 & 210,806 & 1.16 & - - & - - & 50,014 & 0.29 & - - & - - & $2,014,788$ \\
\hline 1920-1929 & 937,860 & 5.20 & - - & - - & 494,417 & 2.73 & 0 & - & $2,523,754$ \\
\hline 1930-1939 & $1,222,797$ & 5.49 & 42,332 & 0.02 & 689,676 & 2.75 & 0 & - & 899,767 \\
\hline 1940-1949 & $3,189,026$ & 20.22 & $1,758,504$ & 0.69 & 286,341 & 1.33 & 0 & - & $27,124,158$ \\
\hline $1950-1959$ & $6,632,641$ & 59.70 & $65,804,686$ & 55.14 & $1,843,560$ & 5.17 & 0 & - & $25,443,427$ \\
\hline 1960-1969 & $7,849,000$ & 58.84 & $163,315,000$ & 176.72 & $2,034,000$ & 4.20 & 225,000 & $1,200.0$ & $34,143,000$ \\
\hline 1970-1979 & $7,405,000$ & 88.97 & $489,522,000$ & $1,004.88$ & $47,930,000$ & 137.35 & 502,000 & $8,217.0$ & $77,501,000$ \\
\hline 1980 & 800,000 & 16.00 & $40,000,000$ & 86.00 & $3,700,000$ & 15.40 & 50,000 & $2,000.0$ & 97,500 \\
\hline 1981 & 800,000 & 17.60 & $46,000,000$ & 88.20 & $4,200,000$ & 19.30 & - - & - - & 256,000 \\
\hline 1982 & 830,000 & 18.00 & $45,000,000$ & 91.00 & $3,400,000$ & 15.60 & - - & - - & 150,000 \\
\hline 1983 & 830,000 & 18.00 & $50,000,000$ & 105.00 & $5,270,000$ & 25.00 & - - & -- & 242,000 \\
\hline 1984 & 849,161 & 23.75 & $27,000,000$ & 95.00 & $2,700,000$ & 16.00 & - - & - - & 875,875 \\
\hline 1985 & $1,370,000$ & 39.73 & $28,184,080$ & 112.06 & $2,500,000$ & 12.00 & - - & - - & 559,000 \\
\hline 1986 & $1,492,707$ & 40.10 & $20,873,110$ & 75.76 & $4,200,000$ & 20.32 & - - & - - & 384,800 \\
\hline 1987 & $1,508,927$ & 42.35 & $16,696,374$ & 42.66 & $1,805,000$ & 11.62 & - - & - - & 388,400 \\
\hline 1988 & $1,551,162$ & 44.30 & $17,264,500$ & 48.75 & $3,600,000$ & 24.65 & - - & - - & 389,000 \\
\hline 1989 & $1,452,353$ & 41.46 & $14,418,000$ & 39.88 & $2,914,000$ & 20.34 & - - & -- & $1,492,000$ \\
\hline 1990 & $1,576,000$ & 44.99 & $15,013,500$ & 40.82 & $3,200,000$ & 22.10 & - - & - - & 400,000 \\
\hline 1991 & $1,540,000$ & 39.00 & $14,160,011$ & 45.45 & $3,000,000$ & 22.50 & - - & - - & 462,000 \\
\hline 1992 & $1,531,800$ & 38.30 & $14,599,746$ & 42.20 & $2,900,000$ & 22.97 & - - & - - & 430,000 \\
\hline 1993 & $1,586,545$ & 38.10 & $13,162,402$ & 40.64 & $3,561,324$ & 26.21 & - - & - - & 465,000 \\
\hline 1994 & $1,490,000$ & 36.75 & $13,518,321$ & 40.95 & $3,843,953$ & 27.04 & - - & - - & 459,500 \\
\hline 1995 & $1,640,000$ & 41.30 & $9,847,550$ & 30.89 & $2,811,152$ & 22.13 & - - & - - & 182,500 \\
\hline 1996 & $1,481,000$ & 38.00 & $9,890,463$ & 32.20 & $3,000,045$ & 23.56 & - - & - - & 200,000 \\
\hline 1997 & $1,446,000$ & 38.05 & $13,800,000$ & 51.91 & $3,200,000$ & 20.00 & - - & - - & 217,000 \\
\hline 1998 & $1,339,000$ & 35.23 & $12,363,450$ & 57.28 & $1,636,200$ & 14.04 & - - & - - & 215,000 \\
\hline 1999 & $1,560,000$ & 41.05 & $10,600,000$ & 52.42 & $1,640,000$ & 18.01 & - - & - - & 190,000 \\
\hline 2000 & $1,473,355$ & 38.77 & $10,600,000$ & 49.86 & $5,200,000$ & 36.59 & - - & - - & 203,000 \\
\hline 2001 & $1,537,000$ & 48.11 & $10,360,000$ & 55.22 & $3,091,000$ & 27.18 & - - & - - & 205,000 \\
\hline 2002 & $1,158,000$ & 37.40 & $22,412,000$ & 120.70 & $3,152,000$ & 31.44 & - - & -- & 200,000 \\
\hline 2003 & $1,088,000$ & 38.08 & $11,868,001$ & 64.14 & 861,382 & 10.41 & - - & - - & 175,000 \\
\hline 2004 & $1,450,000$ & 50.75 & $19,576,092$ & 101.51 & $7,312,050$ & 106.21 & - - & - - & $2,732,554$ \\
\hline 2005 & $1,402,174$ & 49.08 & $16,620,009$ & 76.54 & $2,803,172$ & 22.55 & - - & - - & 809,642 \\
\hline 2006 & $1,397,500$ & 48.91 & $13,953,465$ & 63.35 & $2,369,738$ & 23.85 & - - & -- & $1,057,500$ \\
\hline 2007 & $1,273,004$ & 44.56 & $14,163,676$ & 76.12 & $2,211,954$ & 25.51 & -- & -- & $1,085,500$ \\
\hline 2008 & $1,538,000$ & 53.83 & $12,461,685$ & 72.44 & $2,485,820$ & 39.55 & - - & - - & $1,159,502$ \\
\hline 2009 & $1,861,714$ & 65.16 & $7,072,037$ & 41.37 & $1,837,090$ & 27.23 & - - & - - & $3,678,930$ \\
\hline Other & - - & - - & - - & - - & $2,300,000^{\mathrm{e}}$ & W & 79,000 & W & - - \\
\hline TOTAL & $68,353,175$ & 06.63 & $91,920,993$ & $\mathbf{3 , 1 7 7 . 7 7}$ & $47,756,716$ & 903.34 & 856,000 & $11,417.0$ & $39,258,500$ \\
\hline
\end{tabular}

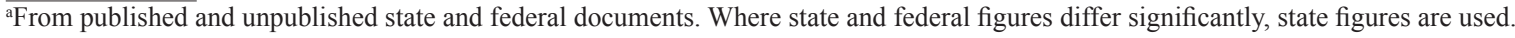
bPlease refer to previous editions of this appendix for year-to-year production information for years 1900 to 1979.

'Building-stone production figures for 1880-1937 are for the southcentral and interior regions of Alaska only.

dIncludes 2.4 million lb U3O8 (1955-71); 505,000 tons gypsum (1905-26); 286,000 lb WO3 (intermittently 1916-80); 94,000 lb asbestos (194244); 540,000 lb graphite (1917-18 and 1942-50); and undistributed amounts of zinc, jade, peat, clay, soapstone, miscellaneous gemstones, and other commodities (1880-1993).

eMarble quarried on Prince of Wales Island, southeastern Alaska (1900-41)

$\mathrm{m} \$=$ Million dollars

$\mathrm{t} \$=$ Thousand dollars

- - = Not reported

$\mathrm{W}=$ withheld 



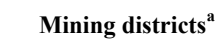

1 Lisburne district

$\begin{array}{lll}3 & \text { Wainwright distric } \\ 4 & \text { Barrow district } \\ 5 & \text { Cowite }\end{array}$

$\begin{array}{ll}4 & \text { Barrow district } \\ 5 & \text { Colville distric } \\ 6 & \text { Canning distric } \\ 7 & \text { S }\end{array}$

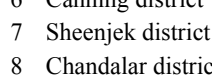

8 Chandalar distric
9 Koyukuk district

11 Kiana \& Selawik districts

12 Fairhaven district (Candle subdistrict)
13.3 Farirhaven district (Inmachuk subdistrtict)

14 Serpentine distric

16 Kougarok district

78 Nome (Cape Nome) distrie

18 Council distric

20 Hughes distric

21 Kaiyun districe

23 Marshall district
24 Bethel district

25 Goodnews Bay district
26 Aniak district

26 Aniak district

28 McGrath district

29 Innoko district
30 Ruby district

1 Kantishna distric

32
33 Met Spriozing ditistrtict

34 Rampart district

6 Yukon

37 Circle distric
38 Black distric

40 Fortymile distric

41 Chisana distric

42 Goodpaster distriic

45 Bonnifield district

46 Richardson subdistrict of Fairbanks distric

7 Delta River district

49 Valdez Creek distric

50 Yentna district

Bristol Bay Regioñ

33 Alaska Peninisula Region (53a) \& Kodiak distrtict (53b)

54 Homer district'
55 Hope \& Seward districts

Willow Creak district

58 Prince William Sound dis

(5)

61 Yakataga distric
62 Yakutat districte

63. Juneau district (partial)

(64) districs

66 Petersburg distric

67 Kupreanof distric

90 Ketchikan distric
Bering Sea Region
B.

71 Aleutian Islands Region

Aleutan Ilands Region
Unknown (undistributed)
TOTn

Production (in refined troy ounces)
Placer

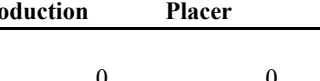

Districts producing more than

,000,000 ounces of gold

Districts producing more than

$1,000,000$ ounces of gold

Total gold production in

Alaska by mining district

1880-2009 